FACULDADE DE FILOSOFIA, CIÊNCIAS E LETRAS DE RIBEIRÃO PRETO

\title{
Redes sociais e apoio social no contexto dos transtornos alimentares
}

\section{CAROLINA LEONIDAS}

Dissertação apresentada à Faculdade de Filosofia, Ciências e Letras de Ribeirão Preto da USP, como parte das exigências para obtenção do título de Mestre em Ciências.

Área de Concentração: Psicologia

Orientador: Prof. Dr. Manoel Antônio dos Santos 



\section{CAROLINA LEONIDAS}

\section{Redes sociais e apoio social no contexto dos transtornos alimentares}

Dissertação apresentada à Faculdade de Filosofia, Ciências e Letras de Ribeirão Preto da USP, como parte das exigências para obtenção do título de Mestre em Ciências.

Área de Concentração: Psicologia

Orientador: Prof. Dr. Manoel Antônio dos Santos

RIBEIRÃO PRETO - SP 
Autorizo a reprodução e divulgação total ou parcial desta Dissertação, por qualquer meio convencional ou eletrônico, para fins de estudo e pesquisa, desde que citada a fonte.

FICHA CATALOGRÁFICA

Leonidas, Carolina

Redes sociais e apoio social no contexto dos transtornos alimentares. Ribeirão Preto, 2012.

227 p.: il. ; $30 \mathrm{~cm}$

Dissertação de Mestrado, apresentada à Faculdade de Filosofia, Ciências e Letras de Ribeirão Preto, Universidade de São Paulo - USP. Área de concentração: Psicologia.

Orientador: Santos, Manoel Antônio dos.

1. Redes sociais. 2. Apoio social. 3. Família. 4. Transtornos alimentares. 
Apoio financeiro:

Esta Dissertação foi parcialmente financiada pela Coordenação de Aperfeiçoamento de Pessoal de Nível Superior (CAPES), mediante concessão de bolsa de mestrado no período de abril a julho de 2010.

De agosto de 2010 a março de 2012, a pesquisa recebeu apoio da Fundação de Amparo à Pesquisa do Estado de São Paulo (FAPESP), mediante concessão de bolsa de mestrado, processo no 2010/1257-7.

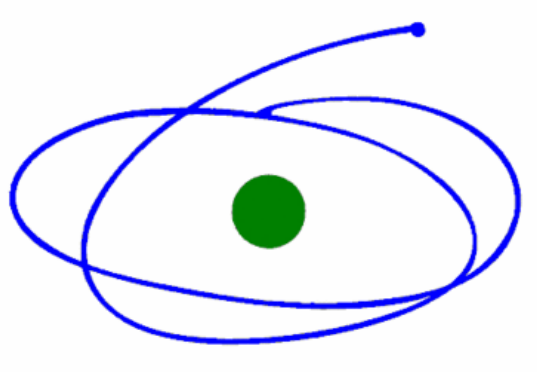

C A P E S

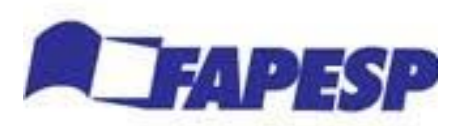



Leonidas, Carolina

Redes sociais e apoio social no contexto dos transtornos alimentares

Dissertação apresentada à Faculdade de Filosofia, Ciências e Letras de Ribeirão Preto da USP, como parte das exigências para a obtenção do título de Mestre em Psicologia.

Aprovado em:

Banca Examinadora

$\operatorname{Prof}(a)$.

Instituição

Julgamento

Assinatura

$\operatorname{Prof}(a)$.

Instituição

Julgamento

Assinatura

Prof(a).

Instituição

Julgamento

Assinatura 

Dedico esta Dissertação à minha família, minha rede mais significativa de apoio social. 



\section{AGRADECIMENTOS}

Ao Prof. Dr. Manoel Antônio dos Santos, pelo exemplo como profissional e pesquisador em Psicologia, que me possibilitou tanto crescimento e aprendizado ao longo dos cinco anos em que estivemos trabalhando juntos, desde minha Iniciação Científica. Só tenho a agradecer pelo acolhimento proporcionado desde 2007, pelo compromisso e envolvimento demonstrados em cada etapa de minha formação e por sua incansável dedicação à formação de novos pesquisadores. Espero que este tenha sido mais um de muitos trabalhos que ainda nascerão de nossa fecunda parceria como pesquisadores no campo da Psicologia Clínica e da Psicologia da Saúde.

Aos membros do Grupo de Assistência em Transtornos Alimentares (GRATA - HCFMRP-USP): Profa. Dra. Rosane Pilot Pessa Ribeiro, Prof. Dr. José Ernesto dos Santos, Dra. Érika Arantes de Oliveira-Cardoso, Elide Valdanha, Lílian Costa, Marina, Felícia, Tatiana e estagiárias de Psicologia e de Nutrição, por iluminarem o meu conhecimento e tornarem menos árduo o meu trabalho com um tema tão complexo como os transtornos alimentares, e por terem me proporcionado a oportunidade da rica convivência com uma equipe que realmente trabalha de forma multi e interdisciplinar.

Aos membros do Grupo de Ensino e Pesquisa em Psicologia da Saúde (NEPPS-FFCLRPUSP-CNPq), pelo intercâmbio de experiências e conhecimentos, fundamentais para a consolidação de minha trajetória como pesquisadora em formação.

À Profa. Dra. Maria Aparecida Crepaldi, por apontar caminhos criativos para a construção deste trabalho e por colaborar com o meu conhecimento acerca da teoria das redes sociais e das relações familiares.

À Profa. Dra. Rosane Pilot Pessa Ribeiro, por sempre disponibilizar tempo e esforços para me ajudar com questões profissionais, e por ampliar meu conhecimento na área dos transtornos alimentares, possibilitando de muitas formas o desenvolvimento deste estudo.

À Profa. Dra. Lucila Castanheira Nascimento, pela disponibilidade em me ajudar com a construção dos genogramas e pelo esclarecimento das dúvidas a respeito do referencial teórico adotado.

Às amigas Tati, Manu, Aninha, Élide, Camila, Andressa, Lilian, Lilo, Tatá e Hannayo, pela amizade e companhia constantes, e por compartilharem comigo as inevitáveis angústias que surgiram ao longo do caminho. 
A todos os outros amigos, pelo apoio e torcida de sempre.

Ao Leandro Barbosa Novo, pelo carinho, dedicação e amor de sempre, pela compreensão frente aos momentos de afastamento durante a construção deste percurso, pelo apoio ao longo desse processo e por me fazer cada dia mais feliz. E também pela confecção laboriosa dos genogramas e pela arte gráfica da capa.

Aos meus irmãos Mariana e Fábio, por serem as melhores companhias, e por fazerem da nossa casa um lugar feliz, repleto de barulho, risadas, seriados, músicas e tudo que torna a minha vida mais leve.

Aos meus pais, os melhores do mundo, por não medirem esforços para tornarem tudo possível. Amo vocês.

À Coordenação de Aperfeiçoamento de Pessoal de Nível Superior - CAPES pelo apoio financeiro concedido nos primeiros meses de desenvolvimento da pesquisa.

À Fundação de Amparo à Pesquisa do Estado de São Paulo - FAPESP, pela concessão de bolsa de mestrado, pelo apoio financeiro para a realização desta pesquisa e pelo aval científico que esse apoio representa.

À equipe da Vinci Comunicação, pela arte gráfica e impressão desta dissertação.

Por fim, agradeço a todos que, de alguma forma, colaboraram para a realização deste trabalho. 


\section{RESUMO}

Leonidas, C. (2012). Redes sociais e apoio social no contexto dos transtornos alimentares. Dissertação de Mestrado, Faculdade de Filosofia, Ciências e Letras de Ribeirão Preto, Universidade de São Paulo, Ribeirão Preto, SP.

Os transtornos alimentares (TA) têm adquirido crescente visibilidade nos últimos anos, despertando forte interesse da comunidade científica e do público em geral. Caracterizam-se por graves perturbações no comportamento alimentar. Os principais subtipos de TA são: a bulimia nervosa (BN) e a anorexia nervosa (AN). A BN é caracterizada por repetidos episódios de compulsão alimentar, que despertam sensação de perda de controle e, na maioria dos casos, são seguidos de rituais purgativos e não-purgativos, tais como: exercícios físicos excessivos, vômitos auto-induzidos e uso abusivo de laxantes, diuréticos e anorexígenos. Já a AN é caracterizada por recusa do indivíduo em manter o peso corporal na faixa mínima adequada, temor intenso de ganhar peso e perturbação significativa na imagem corporal. Partindo-se da hipótese de que os relacionamentos que as mulheres diagnosticadas com esses quadros estabelecem ao longo de sua vida tendem a ser instáveis e bastante conturbados, e que essa fragilidade dos laços afetivos pode estar relacionada com a ocorrência do transtorno, o presente estudo teve por objetivo investigar o modo como se configuram as redes sociais de mulheres com TA, assim como o apoio social percebido por elas e suas possíveis implicações para a evolução do quadro psicopatológico. Trata-se de um estudo do tipo exploratório e descritivo, com enfoque qualitativo. A amostra de conveniência foi composta por 12 mulheres jovens e adultas com TA, vinculadas ao Grupo de Assistência em Transtornos Alimentares (GRATA) do Hospital das Clínicas da Faculdade de Medicina de Ribeirão Preto da Universidade de São Paulo (HC-FMRP-USP). Os instrumentos utilizados para a coleta dos dados foram: entrevista semi-estruturada, Genograma, Mapa de Redes e Critério de Classificação Econômica Brasil/2010, aplicados individualmente em sala reservada da instituição hospitalar. As entrevistas foram gravadas em áudio e, posteriormente, transcritas na íntegra. O material coligido foi submetido à análise de conteúdo na modalidade temática. Os dados foram interpretados com o apoio do referencial teórico da rede social, complementado pelo referencial de apoio social. Os resultados indicam que as redes sociais das participantes são amplas, porém com má distribuição dos membros entre os quadrantes que compõem os Mapas de Redes, notando-se concentração no quadrante da Família. As redes de amigos, colegas de trabalho/faculdade e da comunidade incluem um número de membros significativamente menor do que a rede familiar. A vida social das participantes é marcada por isolamento, que resulta em escassez de redes de amizade, favorecendo a predominância da rede familiar e comprometendo o potencial de apoio. Consequentemente, há prejuízos no bem-estar físico e psicológico, agravando o quadro psicopatológico. A família caracteriza-se como a principal fonte de apoio social, apesar da existência de vários conflitos. Acredita-se que os resultados obtidos favorecem a compreensão, por parte dos profissionais da área, do modo como as relações que as mulheres com TA estabelecem com as pessoas de seu contexto de vida podem influenciar o curso do quadro, de modo a contribuir para o aprimoramento das estratégias de tratamento e prevenção.

Palavras-chave: transtornos alimentares, redes sociais, apoio social, família. 



\begin{abstract}
Leonidas, C. (2012). Social networks and social support in the context of eating disorders. Dissertation (Master's Degree), Faculdade de Filosofia, Ciências e Letras de Ribeirão Preto, Universidade de São Paulo, Ribeirão Preto, SP.
\end{abstract}

Eating disorders (ED) have been gaining increasing visibility in recent years, arousing great interest from the scientific community and the general public. These disorders are characterized by severe disturbances in eating behavior. The main subtypes of ED are bulimia nervosa (BN) and anorexia nervosa (AN). BN is set by repeated episodes of binge eating that evoke feelings of loss of control and, in most cases, are followed by purging and not purging rituals, such as excessive exercise, self-induced vomiting and abuse of laxatives, diuretics and appetite suppressants. AN, on the other hand, can be characterized by an individual's refusal to maintain body weight at the minimum appropriate range, an intense fear of gaining weight and a significant disturbance in body image. Based on the hypothesis that the relationships that these patients establish throughout their lives tend to be very unstable and troubled, and that the weakness of bonding may be related to the occurrence of the disorder, this study aimed to investigate how the social networks of women with ED are set, as well as the perceived social support and its possible implications for the evolution of the psychopathology. This is an exploratory and descriptive study that uses a qualitative approach. The sample was composed of 12 young and adult women with ED, linked to the Group of Assistance on Eating Disorders (GRATA), from the Clinics Hospital of Ribeirão Preto's Faculty of Medicine, University of São Paulo (HC-FMRP -USP). The instruments used for data collection were semi-structured interview, Genogram, Networks' Map and Brazilian Economic Classification Criterion/2010, which were individually applied in a private room at the hospital. The interviews were audio-recorded and later transcribed in full. The collected material was subjected to content analysis in thematic modality. The data were interpreted with the support of the theoretical framework of social network, supplemented by reference to social support. Results indicated that participants' social networks were extensive, but poorly with members distributed among the quadrants of the Networks' Map, with concentration in the Family quadrant. Friends, work/university colleagues and community networks' included a total of members significantly less than the family network. Participants' social life was marked by isolation, which resulted in a scarcity of friendship networks, favoring the predominance of family network and compromising the potential for support and, consequently, the physical and psychological well-being, and worsening the psychopathology. The family was characterized as the main source of social support, despite the existence of several conflicts. It is believed that the results of this study may contribute to the professional's understanding on how the course of patient's disorder can be influenced by the relationships that they establish with the people in their life context, so as to contribute to improve the treatment and prevention strategies.

Keywords: eating disorders, social networks, social support, family. 



\section{LISTA DE TABELAS}

Tabela 1. Características de estrutura, funcionalidade e atributos dos vínculos das redes sociais com suas respectivas funções, adaptado por Andreani, Crepaldi e Custódio (2006), a partir de Sluzki (1997)....

Tabela 2. Caracterização das participantes segundo o diagnóstico, peso, altura, IMC na admissão e no momento da avaliação, e tempo de tratamento no serviço

Tabela 3. Distribuição da pontuação no CEEB/10 e renda média familiar no ano de 2008 , em função da classe econômica 65

Tabela 4. Caracterização sociodemográfica das participantes do estudo

Tabela 5. Eixo A - Aspectos da vivência do TA na perspectiva das participantes.

Tabela 6. Eixo B - Configuração das redes sociais significativas das participantes 



\section{LISTA DE FIGURAS}

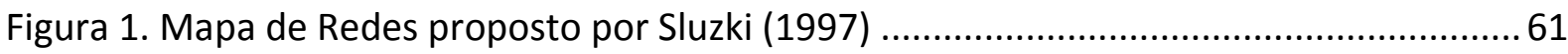

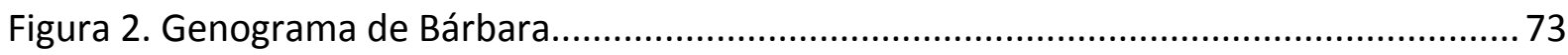

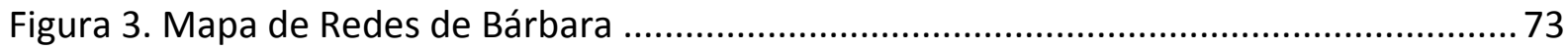

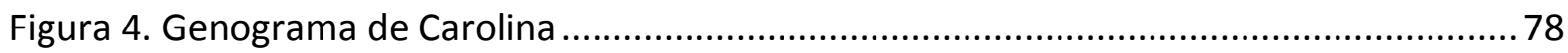

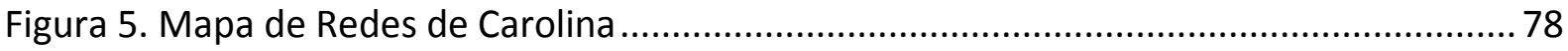

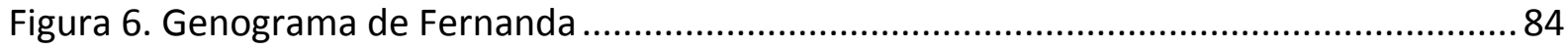

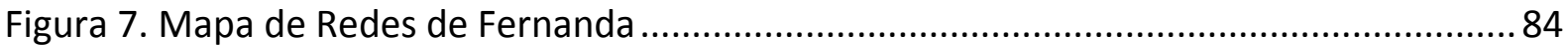

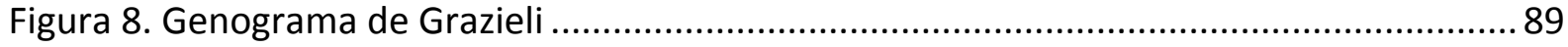

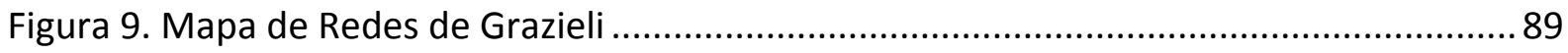

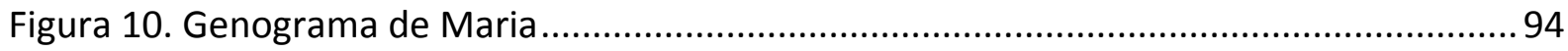

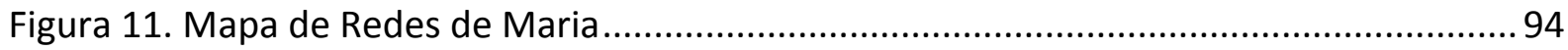

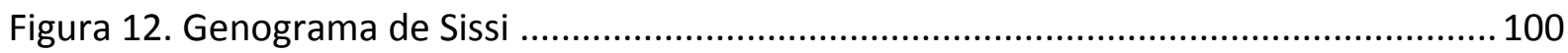

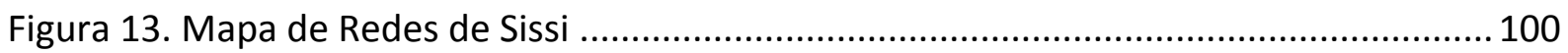

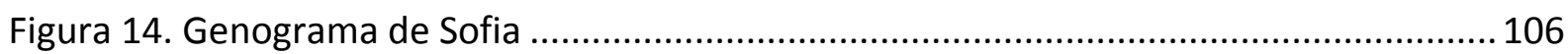

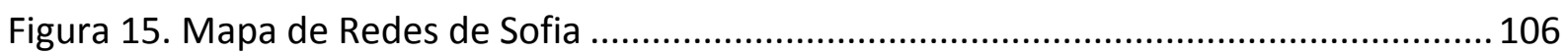

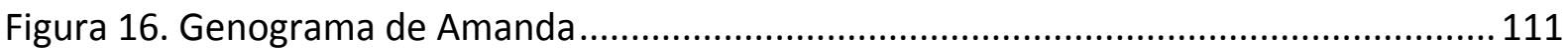

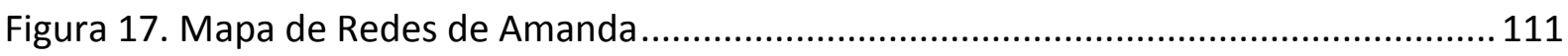

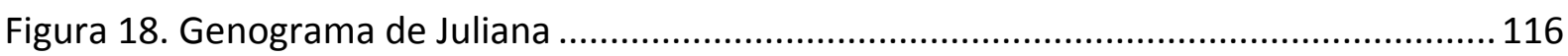

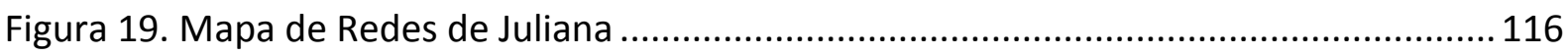

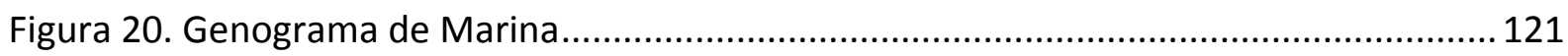

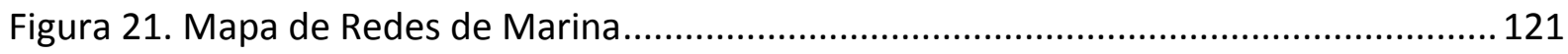

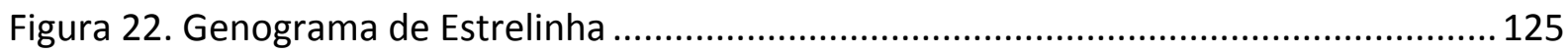

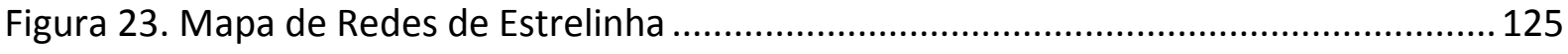

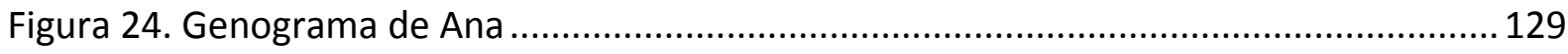


Figura 25. Mapa de Redes de Ana

Figura 26. Composição das redes sociais das participantes .................................................159

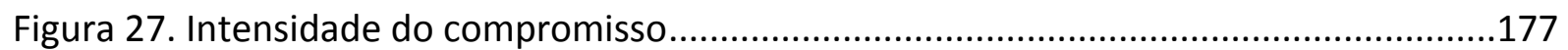

Figura 28. Estimativa da frequência dos contatos com os membros das redes ...................180

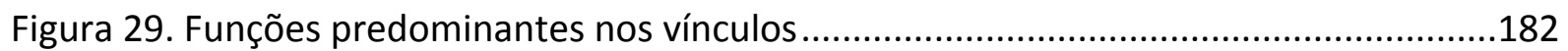

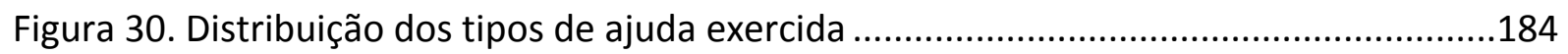

Figura 31. Funções de ajuda desempenhada pelas participantes aos membros de suas respectivas redes sociais significativas 


\section{LISTA DE SIGLAS}

ABA

ABEP

ABIPEME

AN

ANEP

BN

CCEB

CAPES

FAPESP

GRATA

HC-FMRP-USP

NEPPS

TA

USP
Associação Brasileira de Anunciantes

Associação Brasileira de Empresas de Pesquisa

Associação Brasileira dos Institutos de Pesquisa de Mercado

Anorexia Nervosa

Associação Nacional de Empresas de Pesquisa

Bulimia Nervosa

Critério de Classificação Econômica Brasil

Coordenação de Aperfeiçoamento de Pessoal de Nível Superior

Fundação de Amparo à Pesquisa do Estado de São Paulo

Grupo de Assistência em Transtornos Alimentares

Hospital das Clínicas da Faculdade de Medicina de Ribeirão Preto da Universidade de São Paulo

Núcleo de Ensino e Pesquisa em Psicologia da Saúde

Transtornos Alimentares

Universidade de São Paulo 



\section{SUMÁRIO}

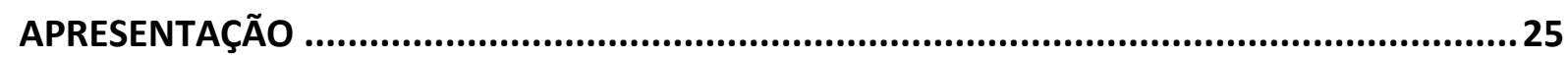

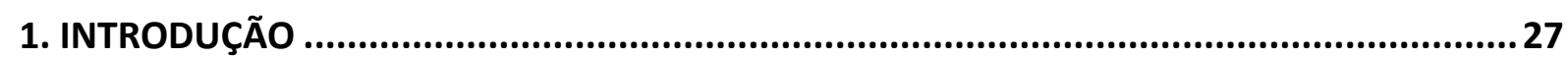

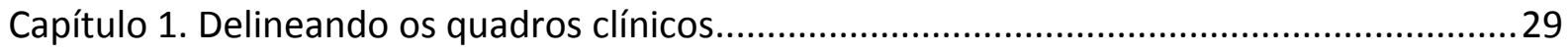

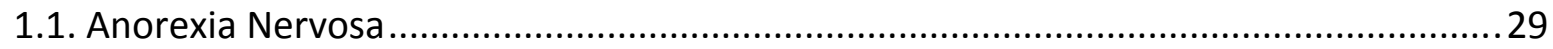

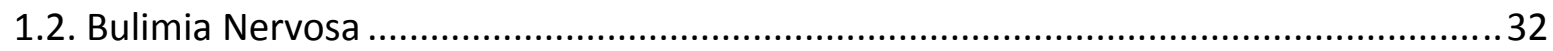

Capítulo 2. Marco teórico: Redes sociais e apoio social ............................................................36

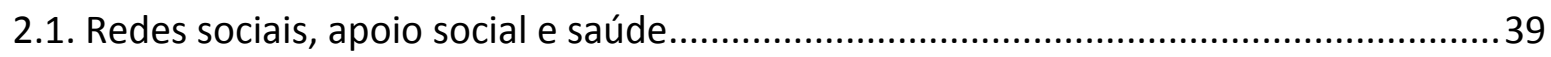

Capítulo 3. Rede e apoio social no contexto dos transtornos alimentares ..............................42

Capítulo 4. Transtornos alimentares e relações familiares..................................................47

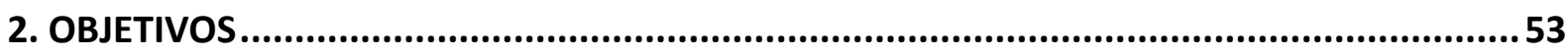

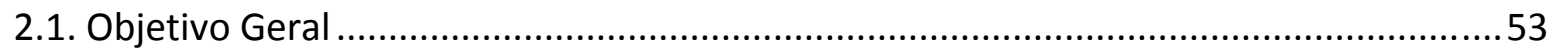

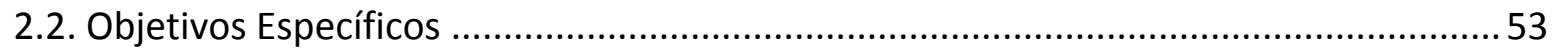

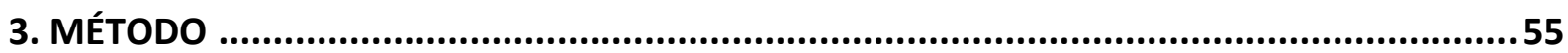

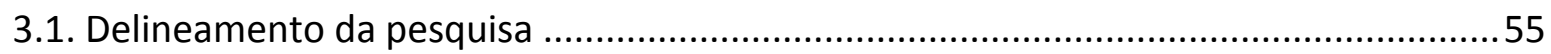

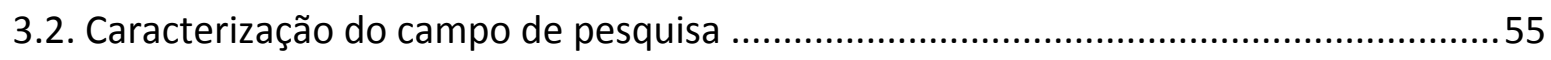

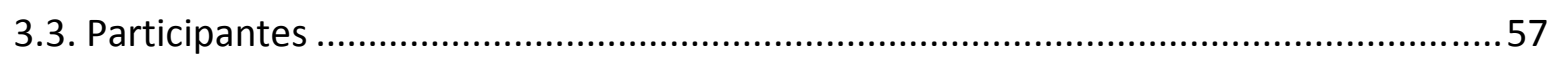

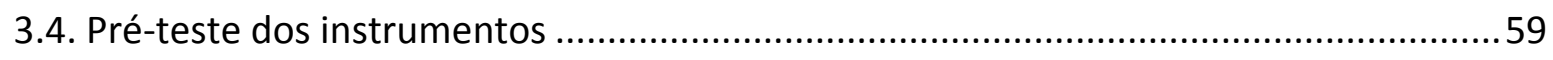

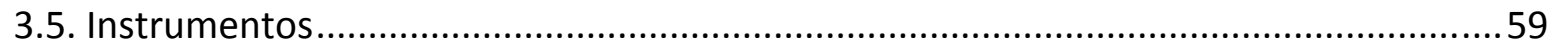

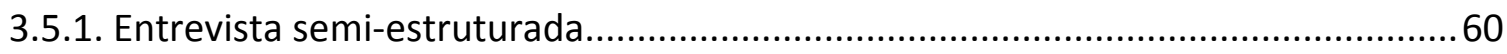

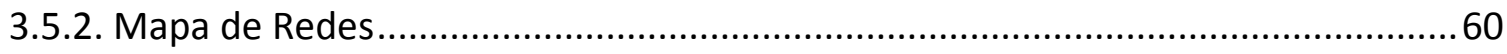

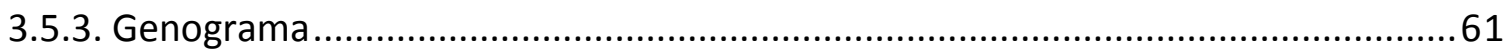

3.5.4. Critério de Classificação Econômica Brasil/2010 (CCEB/10) ..................................64

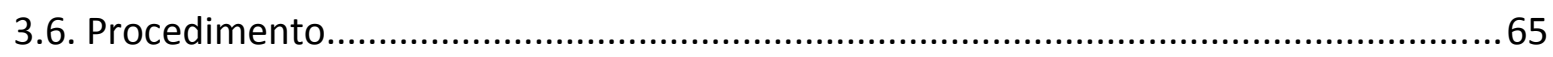

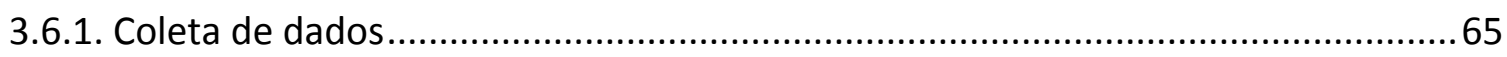

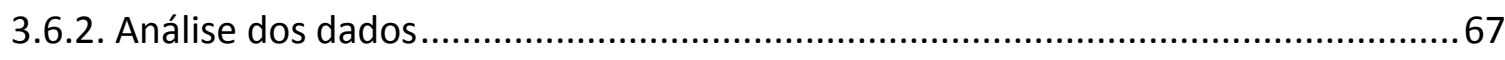

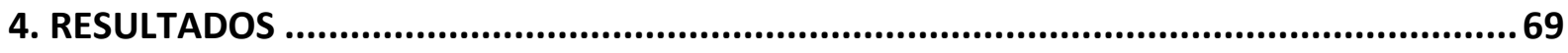

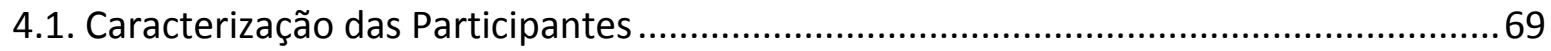

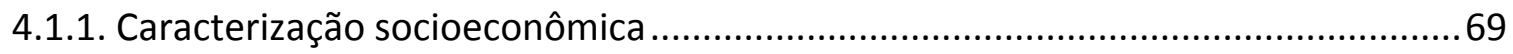


4.1.2. Contextualização da trajetória de vida das participantes: A singularidade das vivências do TA, da configuração das redes sociais significativas e da percepção do apoio social recebido

4.2. Apresentação dos eixos de análise dos resultados

5. DISCUSSÃO 137

5.1. Eixo $A$ - Aspectos da vivência do TA das participantes 137

5.1.1. Categoria A1 - Circunstâncias anteriores ao TA... 138

5.1.2. Categoria A2 - Atribuições de significados relacionados ao início do TA 141

5.1.3. Categoria $A 3$ - Vivências e dificuldades decorrentes do TA 144

5.1.4. Categoria A4 - Sentimentos vivenciados após a instalação do TA 150

5.1.5. Categoria A5 - Mudanças desejadas. 154

5.2. Eixo $B$ - Configuração das redes sociais significativas . 156

5.2.1. Categoria B1 - Aspectos estruturais da rede social significativa 156

5.2.2. Categoria B2 - Atributos do vínculo 174

5.2.3. Categoria B3 - Funções da rede 188

5.2.4. Categoria B4 - Organização das redes sociais significativas e caracterização da

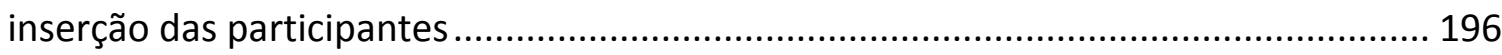

5.2.5. Categoria B5 - Rede social institucional: Considerações acerca do tratamento......... 203

ANEXOS.

Anexo 1. Legendas dos Genogramas, segundo Wendt e Crepaldi (2008), baseado em McGoldrick e Gerson (1995)

Anexo 2. Critério de Classificação Econômica Brasil 2010

Anexo 3. Aprovação do Comitê de Ética em Pesquisa do Hospital das Clínicas da Faculdade de Medicina de Ribeirão Preto da Universidade de São Paulo (HC-FMRPUSP)

APÊNDICES

Apêndice 1. Roteiro de entrevista semi-estruturada. 223

Apêndice 2. Termo de Consentimento Livre e Esclarecido. 


\section{APRESENTAÇÃO}

Durante o curso de graduação em Psicologia tive a oportunidade de me aproximar do Grupo de Assistência em Transtornos Alimentares do Hospital das Clínicas da Faculdade de Medicina de Ribeirão Preto (GRATA - HCFMRP-USP) por ocasião do desenvolvimento de minha pesquisa de Iniciação Científica. O projeto de pesquisa, intitulado Imagem corporal e atitudes alimentares de pacientes com anorexia nervosa ${ }^{1}$, foi conduzido sob orientação da Profa. Dra. Mariana Araújo Noce e co-orientação do Prof. Dr. Manoel Antônio dos Santos, com apoio financeiro da Fundação de Amparo à Pesquisa do Estado de São Paulo (FAPESP), processo no 08/50869-5. Este estudo surgiu a partir de meu interesse movido pela curiosidade acerca do tema dos transtornos alimentares. Esse interesse fez germinar em mim o desejo de conhecer o funcionamento psíquico das pacientes acometidas por esses quadros. No ano de 2007 passei a frequentar e a observar semanalmente as reuniões de equipe multidisciplinar do GRATA, além de realizar a coleta de dados da pesquisa de Iniciação Científica.

Em 2009, com a observação dos grupos de apoio psicológico aos familiares, tive meu primeiro contato com as famílias das pacientes que se encontravam em seguimento regular no serviço. A observação dos grupos, juntamente com a participação nas discussões dos casos durante as reuniões da equipe, possibilitaram que eu percebesse as dificuldades que as pacientes apresentavam em criar e manter vínculos duradouros com as pessoas de seu meio, fazendo com que a família se tornasse a principal - e, às vezes, única - rede social significativa. Tendo em vista que essas dificuldades poderiam resultar em acentuado isolamento social, me vi diante da seguinte questão: quais as possíveis consequências do isolamento social sobre o curso do quadro de transtorno alimentar? Percebi, então, que essa questão me remetia a outras indagações, tais como: de que forma se configuram as redes sociais das mulheres acometidas por transtornos alimentares? Como o apoio fornecido pelos membros dessas redes é percebido pelas pacientes? De que modo a percepção do apoio recebido pode influenciar a evolução do quadro psicopatológico?

Os questionamentos mencionados motivaram a busca de novos horizontes e serviram de balizadores para minha pesquisa em nível de Mestrado, na qual busquei

\footnotetext{
${ }^{1}$ LEONIDAS, C. (2007). Imagem corporal e atitudes alimentares de pacientes com anorexia nervosa. Monografia de Conclusão do Curso de Psicologia. Universidade de Ribeirão Preto, Ribeirão Preto, SP.
} 
investigar as redes sociais e o apoio social no contexto dos transtornos alimentares. Ao descortinar essa nova temática, busquei um delineamento metodológico adequado ao objeto de estudo, de modo a permitir-me conduzir a investigação. Para tanto, optei por utilizar, além de um roteiro de entrevista semi-estruturada, dois instrumentos para a coleta de dados: o Genograma, o Mapa de Redes e o Critério de Classificação Econômica Brasil/2010 (CCEB/10). Esses instrumentos foram escolhidos por julgar que poderiam me auxiliar na investigação da configuração das redes sociais significativas e das potenciais fontes de apoio social.

Uma revisão integrativa da literatura ${ }^{2}$ foi realizada com o objetivo de me situar no contexto da literatura científica já consolidada em torno do tema em questão, e me possibilitou constatar que a produção cientifica nessa área do conhecimento ainda é escassa, sugerindo que se trata de um campo de pesquisa que ainda necessita de estudos e sistematização.

De forma sucinta, assim se constituiu o meu percurso em relação ao tema das redes sociais e do apoio social nos transtornos alimentares. A partir do contato com as participantes deste estudo, pude me aproximar cada vez mais do modo como essas mulheres percebem suas relações com as pessoas de seu meio, e também do significado que atribuem e da influência que essas relações exercem sobre sua qualidade de vida. Por fim, pude discorrer acerca da importância das relações sociais para essas mulheres, não apenas no que concerne à manutenção de suas condições de saúde e bem-estar psicológico, mas também na formação de sua própria identidade.

\footnotetext{
${ }^{2}$ Para a revisão integrativa da literatura, foram empreendidas buscas sistemáticas nas seguintes bases indexadoras: MedLine, LILACS, PsycINFO e CINAHL, utilizando-se os descritores: transtornos alimentares, eating disorders, redes sociais, social networks, apoio social, social support, relações familiares e family relations, no período de 2006 a 2010.
} 


\section{INTRODUÇÃO}

Os transtornos alimentares (TA) são quadros psicopatológicos caracterizados por graves perturbações no comportamento alimentar, que afetam, em sua maioria, adolescentes e jovens do sexo feminino (Borges, Sicchieri, Ribeiro, Marchini, \& Santos, 2006; Oliveira \& Santos, 2006). Esses quadros assumem um curso crônico e incapacitante, e podem resultar em prejuízos biológicos, psicológicos e sociais, que acarretam aumento da morbidade e mortalidade. Acometem uma ampla faixa etária - geralmente entre 13 e 21 anos - e podem ter evolução fatal quando não tratados, em função da gravidade da doença ou das consequências dos agravos à saúde. São predominantes em mulheres (90\%) de todas as classes sociais (Cabrera, 2006), sendo o terceiro transtorno mental mais comum entre as mulheres (Björk \& Ahlström, 2008).

Essa problemática é de interesse crescente para a humanidade, uma vez que a incidência de pessoas - principalmente mulheres - que apresentam sintomas de TA vem aumentando desde a segunda metade do século XX (Claudino \& Zanela, 2005). Concomitantemente à essa incidência, houve também um aumento do número de publicações acerca do tema, que englobavam tanto os fatores culturais e sociológicos - nos quais a atratividade e a feminilidade são indissociáveis da magreza nas sociedades contemporâneas - quanto os fatores de influência familiar, de personalidade e somáticos (Giordani, 2006).

Em se tratando de um quadro psicopatológico crônico e de intensa carga emocional, a incidência de um TA causa um impacto muito negativo na vida do indivíduo acometido, assim como na vida dos membros da família, abalando a estrutura e a dinâmica familiar. Apesar de ainda não existir um consenso a respeito da origem desses quadros, sabe-se que a etiologia envolve a interação de vários fatores, tanto intrínsecos quanto extrínsecos ao indivíduo. Tais fatores dão início, precipitam e mantém o transtorno, causando alterações em vários aspectos da vida indivíduo, dentre eles os relacionamentos interpessoais e amorosos, uma vez que a vulnerabilidade emocional do sujeito acometido dificulta o estabelecimento de vínculos.

Todo indivíduo insere-se dentro de uma história que preexiste o seu nascimento (Bertin \& Passos, 2002). Segue-se a isso o estabelecimento de vários tipos de vínculos, que partem de uma interação regular com os membros do contexto de vida ao qual o indivíduo 
pertence. Essas interações que o sujeito estabelece ao longo de sua vida - dentro das relações familiares, sociais e pessoais - fazem parte do processo de constituição de sua identidade. Partindo-se da hipótese de que as mulheres com TA apresentam dificuldades no estabelecimento e na manutenção de relacionamentos interpessoais e afetivos, como já pontuado anteriormente, e considerando que esses relacionamentos são cruciais para a qualidade de vida das pessoas em geral (Vaux, 1988), acredita-se que essas dificuldades podem estar relacionadas com a predisposição, perpetuação e/ou manutenção dos sintomas do quadro psicopatológico.

Considerando que, por motivos muito próprios, os indivíduos acometidos por TA experimentam ansiedades, medos mórbidos e culpas relacionadas à alimentação (Cabrera, 2006), esses quadros acabam por constituir uma série de alterações inadequadas relacionadas à alimentação, estabelecendo quadros clínicos com sintomatologia específica, grave e complexa. A anorexia nervosa (AN) e a bulimia nervosa (BN) são os dois tipos mais prevalentes de TA, segundo o DSM-IV-TR ${ }^{\mathrm{TM}}$ - Manual Diagnóstico e Estatístico de Transtornos Mentais, 4ạ edição (Associação Americana de Psiquiatria, 2002), e serão descritas a seguir. 


\section{Capítulo 1. Delineando os quadros clínicos}

\subsection{Anorexia Nervosa}

De acordo com o DSM-IV-TR ${ }^{\mathrm{TM}}$ (Associação Americana de Psiquiatria, 2002), a AN pode ser caracterizada como uma recusa do indivíduo a manter o peso corporal na faixa normal mínima adequada à sua idade e altura, além de um temor intenso de ganhar peso e uma perturbação significativa na percepção da forma ou tamanho do corpo, resultando em caquexia, ou seja, em uma fraqueza geral do corpo e má disposição corporal decorrente da desnutrição (Claudino \& Borges, 2002; Morgan, Vecchiatti, e Negrão, 2002). Existem, ainda segundo o DSM-IV-TR ${ }^{T M}$, dois subtipos de AN: o restritivo, no qual a paciente perde muito peso em um curto espaço de tempo, devido a dietas, jejuns ou excesso de exercícios físicos, e o purgativo, que se caracteriza por períodos de restrição alimentar intensa, alternados com períodos de compulsão alimentar seguida de rituais purgativos, tais como vômitos autoinduzidos ou uso abusivo de laxantes, diuréticos e drogas anorexígenas.

Segundo Borges et al. (2006), a desnutrição decorrente da AN costuma resultar em algumas complicações clínicas que podem ser descritas como: pele seca e com aspecto amarelado, cabelos finos, queda de cabelos, unhas quebradiças, problemas nos sistemas cardiovascular (bradicardia, arritimias cardíacas, hipotensão), gastrointestinal (retardo do esvaziamento gástrico, constipação, pancreatite, alteração das enzimas hepáticas), renal (edema, cálculo renal), hematológico (anemia, leucopenia), reprodutivo (amenorréia, infertilidade), metabólico (hipocalemia, hipoglicemia, desidratação) e endocrinológico (hipercolesterolemia, aumento do hormônio de crescimento e cortisol).

No que concerne aos aspectos constitucionais que configuram a personalidade de pacientes com AN, vários autores citam inferioridade, inadequação e insegurança, perfeccionismo, obsessividade, compulsividade, emoções negativas, retraimento e condutas de evitação (Borges et al., 2006; Cassin \& Von Ranson, 2005; Nilsson, Sundboom, \& Häglöff, 2008; Peres \& Santos, 2006). Cooper, Deepak, Grocutt e Bailey (2007) sugerem que a experiência de "sentir-se gorda", vivenciada intensamente pelas pacientes com TA, parece estar relacionada a uma combinação de fatores, como angústia, sensações corporais internas e externas, sentimentos de rejeição, exclusão social, além de crenças negativas sobre si mesmas. 
Segundo Morgan et al. (2002), a etiologia dos TA é multifatorial, ou seja, vários fatores interagem entre si de uma forma complexa e se conjugam na produção dos sintomas, envolvendo: vulnerabilidade genética, traços de personalidade, psicopatologia parental, experiências adversas, pressões socioculturais, entre outros. Oliveira e Santos (2006) propõem a hipótese de uma influência combinada da dinâmica familiar - confusão das fronteiras que definem os subsistemas familiares, que dificultaria a formação da própria identidade e individualidade nos membros da família -, do meio cultural e de aspectos da personalidade do indivíduo como fatores concorrentes na etiologia dos distúrbios relacionados com a distorção da imagem corporal, que predispõem ao desenvolvimento de TA.

Os referidos autores classificam esses fatores de interação como predisponentes - ou seja, fatores que aumentam a probabilidade de aparecimento dos transtornos alimentares, mas não os tornam inevitáveis; precipitantes - que marcam o aparecimento dos sintomas do transtorno; e mantenedores - que determinam se o transtorno vai se perpetuar ou não. No entanto, a influência desses fatores na vida do indivíduo vai depender da combinação única que eles adquirem em sua individualidade e sua história pessoal.

Os fatores predisponentes podem ser subdivididos em:

- Individuais: traços de personalidade, baixa autoestima, traços obsessivos e perfeccionistas, história de transtornos psiquiátricos, depressão, transtornos de ansiedade, tendência à obesidade, alterações da neurotransmissão nas vias noradrenérgicas e serotonérgicas, eventos adversos e abuso sexual.

- Familiares: agregação familiar, hereditariedade, padrões de interação familiar, rigidez, intrusividade, evitação de conflitos, desorganização e falta de cuidados.

- Socioculturais: ideal cultural de magreza, hipervalorização do corpo como base para a autoavaliação, influenciando o autoconceito e a autoestima.

Já os fatores precipitantes podem ser caracterizados como rituais de emagrecimento que, no caso da AN, comumente são as dietas e os intensos jejuns. Esses comportamentos são decorrentes de fatores socioculturais comuns às sociedades ocidentais, em que predomina o ideal de magreza, ou de eventos estressores (mudanças de casa ou de escola, divórcio dos pais, puberdade, entre outros). Morgan et al. (2002) pontuam que estudos longitudinais demonstram que a dieta aumenta o risco para o desenvolvimento de transtornos alimentares. Ao aumentar drasticamente a restrição alimentar, o indivíduo fica 
desnutrido, porém o desejo de emagrecer e o medo de engordar, em contrapartida, tendem a aumentar. No entanto, para que a dieta leve a esse desfecho, deve acontecer simultaneamente com a exposição a outros fatores de risco relacionados à predisposição ao transtorno.

Dentre os fatores mantenedores, podemos mencionar os aspectos:

- Fisiológicos: a privação alimentar favorece episódios de compulsão alimentar e esses episódios interferem no metabolismo da glicose e da insulina.

- Psicológicos: a privação alimentar desencadeia pensamentos obsessivos sobre comida e maior necessidade de controle sobre a alimentação.

- Culturais: a magreza vista como símbolo de sucesso e aceitação social.

De acordo com relatos de pacientes, o início do quadro geralmente está relacionado com a ocorrência de algum fator estressante: comentários críticos sobre o peso, término de relacionamento, perda de um ente querido, entre outros eventos traumáticos. Em seguida, o indivíduo passa a viver em função da dieta, da preocupação com seu peso e sua forma corporal, das atividades físicas, de tabelas de calorias e do medo patológico de engordar (Borges et al., 2006). Esse tipo de pensamento obsessivo leva a uma disciplina muito rígida na realização de dietas, cujo êxito acarreta em sentimentos de controle para o indivíduo, fazendo com que este sinta que tem um núcleo de personalidade próprio (Rodríguez, Hernández, \& Bouly, 2000).

O perfil típico dos indivíduos que apresentam quadro de AN é composto pelas características: adolescentes do sexo feminino, raça branca e alto nível socioeconômico e cultural. No entanto, têm-se observado que esse grupo vem se tornando cada vez mais heterogêneo, uma vez que os casos de diagnóstico em adolescentes do sexo masculino, raça negra, pré-adolescentes e pacientes com baixo nível socioeconômico e cultural têm se tornado cada vez mais frequentes (Borges et al., 2006). Além disso, os referidos autores pontuam que a AN costuma ter início entre os 13 e 17 anos de idade, mas casos de início na infância ou após os 40 anos também têm sido observados. Rodríguez et al. (2000) apontam que, dentre os casos de $\mathrm{AN}$, apenas $10 \%$ correspondem à ocorrência em homens.

Quanto à epidemiologia, sabe-se que a incidência de TA aumentou muito nos últimos 20 anos. A AN acomete principalmente mulheres e sua prevalência varia em torno de $2 \%$ a 5\% em mulheres adolescentes e adultas, sendo que entre 1955 e 1984, houve um aumento constante de casos novos entre adolescentes de 10 a 19 anos (Dunker \& Phillipi, 2003). De 
acordo com esses autores, nos Estados Unidos a AN é a terceira doença mais comum entre adolescentes, perdendo para a obesidade e a asma.

Hoek e Hoeken (2003), revisando estudos sobre a incidência da AN, verificaram que esta é de, aproximadamente, oito por 100 mil indivíduos da população por ano. Além disso, entre as décadas de 1950 e 1980, a incidência entre mulheres jovens, mais especificamente entre 15 e 25 anos de idade, e entre adolescentes de 10 a 14 anos, parece ter aumentado. A partir da década de 1980, a incidência da AN tornou-se estável. Sicchieri, Santos, Santos e Ribeiro (2007) pontuam que a incidência de novos casos de TA em mulheres jovens pode variar de 1,4 a 4,8 a cada 100.000 pessoas anualmente, segundo os dados dos EUA e de países da Europa.

Nota-se que, no geral, existe uma ampla variabilidade entre os dados epidemiológicos apresentados pela literatura específica. Isso se deve a diversas razões, desde questões metodológicas - variações nos métodos de avaliação adotados por cada autor - até socioculturais - hiper ou desvalorização da magreza em diferentes culturas, o que dificulta o estabelecimento de um padrão quantitativo relacionado à epidemiologia do transtorno em questão.

\subsection{Bulimia Nervosa}

Bulimia significa, etimologicamente, "fome de boi". Ou seja, o termo remete a um apetite ávido, ao qual o indivíduo se entrega com voracidade e edacidade. Esse apetite, no entanto, não diz respeito apenas aos alimentos em si, mas a uma gama de objetos e atividades (Brusset, 2003). Contrapondo-se à preocupação com a economia e o estabelecimento de medida típicas da cultura contemporânea, a bulimia "aparece como o espelho invertido do culto do rendimento" (p. 8) e ilustra os efeitos do consumo exagerado da lógica de mercado.

O exagero típico dos quadros de BN geralmente ocorre em forma de atos privados e solitários, e configura um ataque à cozinha, à educação e aos costumes aprendidos, subvertendo as necessidades biológicas da fome e contestando o que é aceito ética e esteticamente, assim como as normas, os usos, os aprendizados e a dimensão social da refeição (Brusset, 2003). A partir dos ataques desferidos, surgem as reprovações morais e a vergonha vivenciada pelos indivíduos acometidos por esses quadros. 
A primeira descrição da BN como entidade nosológica foi proposta por Russell, em 1979. O autor caracterizou esse quadro como uma variante da AN, que apresentava um sintoma-chave: o binge eating, ou "farra alimentar". Esse sintoma respondia a três critérios, a saber: (1) os pacientes bulímicos sofriam de intensa e irresistível necessidade de se alimentar de forma excessiva por um determinado período; (2) provocavam vômitos e faziam uso abusivo de laxantes para evitar o ganho de peso; e (3) apresentavam medo mórbido de se tornarem gordos (Rosa \& Santos, 2011; Vindreau, 2003).

Atualmente, segundo o DSM-IV-TR ${ }^{\mathrm{TM}}$ (Associação Americana de Psiquiatria, 2002), constituem critérios diagnósticos para a BN:

1- Episódios recorrentes de compulsão alimentar periódica, que são caracterizados por:

- ingestão, em período limitado de tempo, de uma quantidade de alimentos definitivamente maior do que a maioria das pessoas consumiria em período e circunstâncias similares;

- sentimento de falta de controle sobre o comportamento alimentar durante o episódio (por exemplo, sentimento de incapacidade de parar de comer ou de estimar quanto está comendo);

2- Comportamento compensatório inadequado e recorrente, com o fim de prevenir o aumento de peso, como autoindução de vômitos, uso indevido de laxantes, diuréticos, enemas ou outros medicamentos, jejuns ou exercícios excessivos;

3- A compulsão periódica e os comportamentos compensatórios inadequados ocorrem, em média, pelo menos duas vezes por semana, há três meses;

4- A autoavaliação é indevidamente influenciada pela forma e pelo peso do corpo;

5- O distúrbio não ocorre exclusivamente durante os episódios de AN.

Há dois subtipos de BN: o purgativo, no qual acontecem os episódios de vômitos autoinduzidos e o uso abusivo de laxantes, diuréticos e enemas, e o não-purgativo, no qual o indivíduo realiza intensos jejuns e exercícios físicos excessivos, sem a ocorrência de vômitos e outros comportamentos compensatórios.

O transtorno também está associado a comportamentos impulsivos e comorbidades, tais como traços histriônicos e transtorno de personalidade do tipo borderline (Kaye, 2008; Borges et al., 2006; Paccola, 2006; Vindreau, 2003), a uma autoestima flutuante e a pensamentos e emoções desadaptativas, sendo comum encontrar indícios que apresentam 
atitudes caóticas, não somente no tocante aos hábitos alimentares, mas também em outros aspectos da vida, como os estudos, a vida profissional e as relações amorosas (Oliveira \& Santos, 2006).

Em termos clínicos, as pacientes bulímicas apresentam: pouca perda de peso, peso normal ou até acima do normal; distorção da imagem corporal pouco acentuada; maior incidência por volta dos 20 anos de idade; são mais extrovertidas; referem fome; os comportamentos de compulsão e purgação são motivo de vergonha e culpa, havendo desejo de ocultá-los; são sexualmente ativas; há comorbidades com transtornos afetivos e abuso de álcool e outras drogas (Borges et al., 2006). Além disso, essas mulheres também costumam apresentar baixo limiar à frustração, alto nível de ansiedade, autoestima rebaixada e prejuízos no controle dos impulsos (Rosa \& Santos, 2011).

Do ponto de vista do funcionamento psicológico, as pacientes com BN apresentam uma série de pensamentos e emoções desadaptativas a respeito de seus hábitos alimentares e seu peso corporal (Abreu \& Filho, 2004). Além disso, elas também apresentam autoestima flutuante e acreditam que o corpo bem delineado resolveria seus problemas de insegurança pessoal. Para conseguir alcançar esse corpo idealizado, as mulheres com BN realizam dietas excessivas, rituais purgativos e exercícios físicos extenuantes. Assim, atribui-se o desejo que essas mulheres possuem de emagrecer a uma desorganização pessoal, na qual a regulação e o controle da alimentação seriam uma tentativa de obter ordenação e estabilidade do estado psíquico caótico (Abreu \& Filho, 2004).

Em suma, a arquitetura emocional das mulheres com BN inclui: baixa autoestima, pensamento do tipo "tudo ou nada", ansiedade, perfeccionismo, incapacidade de encontrar formas de prazer e satisfação na vida, busca de problemas mesmo nas coisas corriqueiras, alta exigência, incapacidade de "ser feliz" (Abreu \& Filho, 2004). Segundo Limbert (2010), tais características implicam em uma incapacidade dessas mulheres em desenvolver redes sociais saudáveis, uma vez que elas apresentam dificuldades nos relacionamentos interpessoais e não são socialmente ajustadas.

De acordo com o que é evidenciado pela clínica psicanalítica, a BN é, inicialmente, constituída na economia das experiências de prazer e desprazer que se desenvolvem no cerne das relações afetivas estabelecidas com o próprio corpo e a mãe. Corresponde a uma fixação na etapa oral do desenvolvimento libidinal, à qual o indivíduo regride perante a impossibilidade de acesso ao gozo genital. Brusset (2003) sugere que a BN também surge 
como um "gozo impossível, um tormento, um sofrimento, uma doença" (p. 8), pois, apesar de ser uma conduta aceita - e até mesmo escolhida e desejada - pelo indivíduo, torna-se fonte de angústia e alienação, uma vez que ele se sente tomado por uma necessidade de realizar o ato bulímico, durante o qual se sente fora de si.

No que concerne ao tratamento, Rosa e Santos (2011) sugerem que a psicoterapia auxilia na melhora dos sintomas de quadros de $\mathrm{BN}$, mas é insuficiente como tratamento exclusivo. Até o momento, não há estudos controlados que tratam da eficácia das psicoterapias psicodinâmicas na $\mathrm{BN}$, mas alguns autores apontam que essa modalidade de seguimento contribui para o tratamento das comorbidades, diminuição da ansiedade, melhoria dos relacionamentos interpessoais e elaboração dos traumas por abuso sexual. 0 guia prático para o tratamento dos transtornos alimentares, formulado pela Associação Americana de Psiquiatria (2006), aponta que a psicoterapia psicodinâmica é aplicável aos pacientes mais comprometidos, com maior incidência de comorbidades.

Uma vez delineados os quadros clínicos abordados no presente estudo, será descrito, a seguir, o marco teórico adotado: a teoria das redes sociais (Sluzki, 1997) e do apoio social (Bullock, 2004; Vaux, 1988). 


\section{Capítulo 2. Marco teórico: Redes sociais e apoio social}

A Teoria das Redes Sociais (Sluzki, 1997) trata do "conjunto de seres com quem interagimos de maneira regular, com quem conversamos, com quem trocamos sinais que nos corporizam, que nos tornam reais" (p. 15). Segundo este autor, a identidade é construída e reconstruída constantemente ao longo do ciclo vital, a partir da interação do indivíduo com os outros - familiares, vizinhos, amigos, inimigos, conhecidos, companheiros de grupos, entre outros. Assim, considera-se que todas essas pessoas são parte intrínseca da identidade de cada indivíduo, contribuindo de forma muito particular para a formação de sua personalidade.

As redes sociais têm, como característica primária, o fato de serem abertas e dinâmicas, ou seja, são marcadas pelo inacabamento, estão em permanente construção e têm como princípio básico a conectividade (Custódio, 2010; Moré, 2005; Orlandi, 2011). Dessa forma, pode-se dizer que as redes sociais possibilitam as trocas efetivas entre um indivíduo e os integrantes de entidades coletivas. É por meio dessas trocas que os recursos desses grupos são utilizados de forma a facilitar a resolução de conflitos e a satisfação de necessidades do indivíduo. Além disso, levando-se em conta o processo de constante reconstrução das redes, Orlandi (2011) aponta para a impossibilidade de representá-las em sua totalidade. Resta apenas que o observador da rede visualize a forma como ela está configurada naquele determinado momento, "considerando a sua volatilidade e o contexto de observação" (p. 38).

Segundo Custódio (2010), as redes sociais estão fortemente ligadas ao construto do apoio social, uma vez que é por meio das redes que esse apoio é fornecido. O apoio social remete à ajuda mútua, que pode ser significativa ou não, dependendo do grau de integração da rede. Considerando esse pressuposto, de forma complementar à Teoria das Redes Sociais, o presente estudo se apoia no referencial de Apoio Social de Vaux (1988) e Bullock (2004). Esta última autora sugere que as redes sociais são geralmente compreendidas em termos estruturais, descritas como as interações que o indivíduo estabelece com as instituições sociais que o cercam, tais como família, vizinhança e organizações comunitárias e religiosas. Já a noção de apoio social, por sua vez, enfatiza as trocas interpessoais estabelecidas entre alguns membros da rede. Nesse sentido, o apoio social tem sido considerado como parte importante da promoção de saúde, uma vez que fornece assistência às necessidades físicas e emocionais do indivíduo, assim como ajuda a amenizar o efeito que eventos estressores exercem sobre a qualidade de vida (Bullock, 2004).

Vaux (1988) propõe que os membros que constituem as redes sociais de um indivíduo exercem papel crucial no seu desenvolvimento, encorajando o enfrentamento de 
dificuldades, orientando possíveis caminhos, incentivando o crescimento individual e instigando a tomada de decisões e atitudes. O referido autor sugere que o apoio social também está relacionado com atividades cotidianas, tais como a troca de sentimentos, afetos, tarefas e informação, e com experiências humanas comuns, tais como a alegria do amor, a dor do isolamento, vínculos familiares e laços de amizade.

Segundo Resende, Bones, Souza e Guimarães (2006), apoio social pode ser definido como um sistema de relações formais e informais pelas quais os indivíduos recebem ajuda emocional, material ou de informação para enfrentar situações geradoras de tensão emocional. Deve ser compreendido como uma experiência pessoal e subjetiva, que leva a um maior senso de satisfação com a vida.

Considerando a relação de união entre os conceitos de redes sociais e apoio social, alguns autores (Brito \& Koller, 1999) utilizam o conceito de "rede de apoio social", que trata do "conjunto de sistemas e de pessoas significativas que compõem os elos de relacionamento recebidos e percebidos do indivíduo" (p. 115). Ou seja, essa terminologia diz respeito às pessoas significativas da rede social do indivíduo, que fornecem apoio para o enfrentamento das situações cotidianas, e incentivo para a superação de circunstâncias mais mobilizadoras, tais como situação de doença, luto, entre outros.

Sluzki (1997) utiliza o termo "rede social pessoal" ou "rede social significativa" para caracterizar algumas relações particulares que fazem parte do microssistema do indivíduo, ou seja, que estão inseridas em seu ambiente imediato e que o influenciam de forma direta. O autor define a rede social pessoal como "a soma de todas as relações que um indivíduo percebe como significativas ou define como diferenciadas da massa anônima da sociedade" (p. 42). Assim, Sluzki (1997) estabelece uma diferenciação entre os vários ambientes que fazem parte das inúmeras relações que o indivíduo possui (Custódio, 2010). O referido autor acrescenta ainda que as redes sociais pessoais contribuem para que o indivíduo se reconheça como tal e possa desenvolver sua autoimagem. Ao desenvolver um senso de identidade, bem estar, competência e autoria, o indivíduo também pode se responsabilizar de forma mais ativa pelo cuidados à sua saúde e pela adaptação à situações de crise (Sluzki, 1997). Moré (2005), por sua vez, utiliza a terminologia de "rede pessoal significativa" para denominar essas mesmas relações, descritas por Sluzki (1997) como aquelas que são diferenciadas da massa de pessoas que circundam o indivíduo. Tendo em vista a uniformização dos termos utilizados no presente estudo, optou-se por fazer uso da terminologia adotada por Sluzki (1997), ou seja, "rede social significativa". 
As redes sociais podem ser analisadas a partir de algumas características, definidas por Sluzki (1997) e adaptadas por Andreani, Crepaldi e Custódio (2006). Dentre elas, encontram-se: estrutura - propriedades da rede em seu conjunto, funcionalidade - tipo predominante de intercâmbio interpessoal característico de vínculos específicos e da soma ou combinação do conjunto de vínculos - e atributos dos vínculos - propriedades específicas de cada relação. Essas características são definidas na Tabela 1.

Tabela 1. Características de estrutura, funcionalidade e atributos dos vínculos das redes sociais com suas respectivas funções, adaptado por Andreani, Crepaldi e Custódio (2006), a partir de Sluzki (1997)

\begin{tabular}{|c|c|}
\hline Estrutura das redes & Definição \\
\hline Tamanho & $\begin{array}{l}\text { número de pessoas na rede, preferencialmente não } \\
\text { deve ser nem muito grande, nem muito pequeno; }\end{array}$ \\
\hline Densidade & a conexão entre os membros; \\
\hline Composição ou distribuição & $\begin{array}{l}\text { as redes não devem ser muito centradas em algum } \\
\text { quadrante, pois se tornam menos flexíveis; }\end{array}$ \\
\hline Dispersão & distância geográfica entre os membros; \\
\hline Homogeneidade e heterogeneidade & sexo, idade, cultura e nível socioeconômico. \\
\hline \multicolumn{2}{|l|}{ Funcionalidade das redes } \\
\hline Companhia social & realização de atividades conjuntas; \\
\hline Apoio emocional & $\begin{array}{l}\text { atitudes emocionais positivas como empatia, } \\
\text { compreensão e apoio; }\end{array}$ \\
\hline Guia cognitivo ou de conselhos & $\begin{array}{l}\text { interações para promover o compartilhamento de } \\
\text { informações, esclarecimentos e modelos de papéis; }\end{array}$ \\
\hline Regulação social & $\begin{array}{l}\text { reafirmação de responsabilidades e papéis } \\
\text { neutralizando desvios de comportamento; }\end{array}$ \\
\hline Ajuda material e de serviços & $\begin{array}{l}\text { colaboração baseada em conhecimentos específicos e } \\
\text { especializados, incluindo os serviços de saúde; }\end{array}$ \\
\hline Acesso a novos contatos & $\begin{array}{l}\text { abertura a novas redes que não faziam parte das redes } \\
\text { do indivíduo. }\end{array}$ \\
\hline \multicolumn{2}{|l|}{ Atributos do vínculo } \\
\hline Função predominante do vínculo & $\begin{array}{l}\text { função que caracteriza de maneira predominante um } \\
\text { tipo de vínculo; }\end{array}$ \\
\hline Multidimensionalidade & quantidade de funções desempenhadas pela pessoa; \\
\hline Reciprocidade & simetria entre duas pessoas; \\
\hline Intensidade ou compromisso da relação & grau de intimidade entre os membros da relação; \\
\hline Frequência de contatos & manutenção ou quebra de contato no vínculo; \\
\hline História da relação & $\begin{array}{l}\text { dados sobre desde quando os membros envolvidos no } \\
\text { vínculo se conhecem. }\end{array}$ \\
\hline
\end{tabular}


Custódio (2010) pontua que as variáveis descritas na Tabela 1 são interdependentes e resultam em uma combinação de funções. O grau de funcionalidade das redes é determinado pelos tipos de interações e vínculos existentes entre os membros que as constituem, e as divisões em termos de significância e tipo de vínculo facilitam a decisão de "qual rede pode ser ativada, desativada ou modificada em momentos de crise" (p. 59).

Acredita-se que uma rede bem configurada e fortalecida pode favorecer não apenas o enfrentamento dos eventos cotidianos, mas também os processos de saúde e a qualidade de vida das pessoas (Custódio, 2010; Orlandi, 2011; Sluzki, 1997). O estabelecimento de vínculos confiáveis com os membros da rede possibilita maior apoio e incentivo à prevenção, aos cuidados e à promoção de saúde.

\subsection{Redes sociais, apoio social e saúde}

As redes sociais e o apoio social são tópicos bastante atuais dentro da Psicologia (Resende et al., 2006). O interesse por esses temas vem aumentando desde a década de 1970, principalmente no que diz respeito à relação entre apoio social e indicadores de presença ou ausência de inúmeras doenças e transtornos mentais. Silva et al. (2003) mencionam a existência de uma relação entre apoio social e uma variedade de medidas dependentes, tais como saúde, adaptação psicológica, percepção de bem-estar, redução do mal-estar, longevidade e mortalidade, satisfação com a vida, entre outros. Além disso, a disposição para enfrentar os desafios da vida, lutar pelos direitos e pôr em prática projetos viáveis dentro das condições de possibilidades pessoais e do meio ambiente em que se vive, também parece ser subsidiada por uma rede de apoio social (Marcos \& Cantero, 2009; Resende et al., 2006).

Atualmente, muitas pesquisas a respeito das redes familiares de apoio têm documentado o impacto do apoio social sobre os comportamentos saudáveis, tanto na prevenção quanto no tratamento (Bullock, 2004). Nessa interface do apoio e das redes sociais com a promoção de saúde, a autora sugere que esses construtos estão associados com a redução das taxas de mortalidade, com a melhora de doenças graves e com o aumento da utilização de práticas preventivas de cuidado à saúde. Ao considerar a relação entre apoio social e saúde, a referida autora define o conceito de apoio como o fornecimento ou recebimento de assistência, e sugere que a percepção que o indivíduo possui desse apoio pode ser tanto positiva quanto negativa. 
Sluzki (1997) coloca que a saúde das pessoas está diretamente relacionada com o estabelecimento de uma rede social ativa, estável e confiável, sendo que a ausência desse tipo de relações sociais pode ser considerada fator de risco para o desenvolvimento de doenças. Custódio (2010) propõe que, ao se levar em conta as redes sociais do indivíduo acometido por uma doença ou um transtorno, é possível que os profissionais de saúde identifiquem a teia de interações estabelecidas na situação de crise e verifiquem a forma como as pessoas que fazem parte dessas interações lidam com a doença. Desse modo, esses profissionais podem elaborar planos de intervenção que envolvam papéis e funções definidas para os membros da rede do indivíduo acometido, de forma a envolvê-los ativamente no cuidado.

No que tange ao impacto que uma doença de curso prolongado exerce sobre a qualidade das interações sociais, Sluzki (1997) pontua que, a longo prazo, esse impacto pode resultar na redução tanto do tamanho das redes quanto da possibilidade de acesso a elas. Para ilustrar essa afirmação, o autor desenvolveu os conceitos de círculos virtuosos e círculos viciosos. No primeiro, a presença de uma rede social ativa e confiável protege a saúde do indivíduo acometido pela doença, e a saúde do indivíduo, por sua vez, mantém a rede. Nos círculos viciosos, no entanto, a presença de uma doença crônica afeta de forma negativa a rede social na qual o indivíduo está inserido, comprometendo o potencial de apoio. Dessa forma, a saúde recebe um impacto negativo que reduzirá mais ainda o tamanho e o apoio proveniente da rede, e assim sucessivamente, "em espiral de deterioração recíproca" (p. 67).

Ainda a respeito dos efeitos da doença sobre a qualidade das relações sociais, Vasconcellos (2010) propõe o conceito de ciclo de retroação, ou retroalimentação, proveniente da teoria da Cibernética. Tomando as redes sociais como sistemas, estas podem ser consideradas como um conjunto de componentes - pessoas - em processo de contínua interação. Ou seja, as relações entre os componentes configuram um aspecto central que indica que os sistemas não se tratam de "um simples aglomerado de partes independentes" (Vanconcellos, 2010, p. 199). Nesse sentido, o mecanismo de retroalimentação implica que, conforme o sistema vai funcionando, também vai sendo informado dos resultados ou efeitos produzidos por seu funcionamento.

Sluzki (1997) também buscou especificar alguns modos de como a saúde dos indivíduos e as redes sociais estão relacionadas. $\mathrm{O}$ autor sugere que as redes podem afetar a 
saúde do indivíduo em quatro níveis: nível atávico de base evolutiva - onde a reação de alarme frente ao desconhecido é atenuada pela presença de figuras familiares -, nível existencial - no qual as relações sociais contribuem para dar sentido à vida de seus membros -, nível de prática social - que prediz que a rede social atua como corretiva dos comportamentos disfuncionais relacionados à manutenção da saúde - e o nível de atividades sociais - que estão relacionados com a sobrevida (rotina de dieta, de exercícios, de sono e, em geral, de cuidados à saúde).

Em relação à forma como a doença de um indivíduo afeta sua rede, Sluzki (1997) propõe alguns mecanismos que explicam esse fenômeno. Primeiramente, o autor aponta para um efeito interpessoal aversivo que as doenças possuem, e que geram nos outros condutas evitativas. Além disso, a doença restringe a mobilidade do sujeito, reduzindo a oportunidade de contatos sociais e o isola. Ao debilitar o indivíduo, a doença também reduz as possibilidades desse indivíduo iniciar a ativação necessária da rede, considerando que esta possui uma inércia. Mantendo essa inércia, a participação dos outros membros da rede pode se reduzir drasticamente, o que compromete, por sua vez, as relações interpessoais.

Outra característica das doenças crônicas é a redução da capacidade do indivíduo de gerar comportamentos de reciprocidade, ou seja, a pessoa comprometida tem menos possibilidade de apresentar comportamentos equivalentes aos das pessoas da sua rede, gerando uma assimetria (Sluzki, 1997, p. 78) nas relações que pode causar o distanciamento. Por fim, a necessidade de constante reiteração e a baixa eficácia dos cuidados atribuídos ao indivíduo acometido tornam os comportamentos de cuidado pouco gratificantes, gerando um esgotamento por parte dos cuidadores, que se mantém a despeito da lealdade, da dívida em comum e dos valores éticos (Sluzki, 1997).

De forma geral, o conceito de redes sociais oferece uma compreensão da constituição da identidade do sujeito a partir da vivência nas redes, ou seja, na interação regular com pessoas com quem conversamos ou realizamos trocas significativas (Gutierrez \& Minayo, 2008). Resende et al. (2006) sugerem que essas relações permitem o desenvolvimento do self, dão sentido às experiências e podem suprir as necessidades de apoio, oferecendo subsídios para o processo de adaptação que ocorre ao longo da vida. O entendimento da rede social significativa do sujeito acometido por um TA é fundamental, especialmente quando se pretende compreender as teias de conflito, o potencial familiar de apoio em situação de crise e o núcleo relacional a ser ativado para uma melhor inserção social do indivíduo (Filho \& Nóbrega, 2004). 


\section{Capítulo 3. Rede e apoio social no contexto dos transtornos alimentares}

Buscando-se sintetizar a produção científica nacional e internacional acerca do apoio social e das redes sociais nos TA, de forma a alcançar um aprofundamento acerca do tema e delinear o estado da arte, foi realizada uma revisão integrativa da literatura (Leonidas \& Santos, 2011). Partindo-se da questão temática: “Qual é o papel desempenhado pelo apoio social e pelas redes sociais no contexto dos TA?", optou-se por utilizar quatro bases de dados bibliográficos (MedLine, LILACS, PsycINFO e CINAHL), com período de abrangência da busca de 2006 a 2010.

Para operacionalizar a revisão integrativa foram selecionados os seguintes descritores, segundo o DeCS - Descritores em Ciências da Saúde: transtornos alimentares, eating disorders, apoio social, social support, relações familiares, family relations. Buscando abranger maior quantidade de publicações a respeito do tema em questão, optou-se por incluir também os seguintes descritores não-controlados (palavras-chave): redes sociais e social networks. Os unitermos foram utilizados nas bases de dados de forma combinada.

Após o levantamento das publicações, os resumos foram lidos e analisados. Levandose em conta os critérios de inclusão/exclusão preestabelecidos, foram selecionados 32 artigos para leitura na íntegra e análise. Houve predomínio de estudos publicados em periódicos internacionais, oriundos, principalmente, dos Estados Unidos. Esse dado indica a necessidade de maiores investimentos em publicações nacionais acerca das diversas dimensões do apoio social e das redes sociais em pacientes com TA, especialmente estudos com níveis mais sofisticados de evidência, tais como os experimentais e quaseexperimentais, já que os poucos artigos brasileiros que integraram a presente revisão eram do tipo exploratório e descritivo $(n=1)$ e revisões da literatura $(n=2)$, o que evidencia a carência de estudos randomizados.

Evidenciou-se que ainda não há uma literatura plenamente consolidada a respeito do apoio social e das redes sociais em pacientes com TA, tendo em vista o reduzido número de publicações dedicadas à temática. Houve predomínio de estudos publicados em periódicos internacionais, oriundos, principalmente, dos Estados Unidos.

Foi possível notar que a rede social familiar foi bastante explorada pelos estudos selecionados na revisão integrativa, cujos achados são bastante convergentes, principalmente no que diz respeito às características do funcionamento familiar de 
indivíduos com TA. Por outro lado, evidenciou-se uma carência de estudos a respeito das outras redes e fontes de apoio social, além da família. Não foram encontrados estudos a respeito do papel desempenhado pela religião, pelos vizinhos, por grupos comunitários ou de ajuda mútua e por serviços especializados no tratamento de TA no fornecimento de apoio social aos indivíduos acometidos pelo TA.

A revisão integrativa da literatura é um método de pesquisa que permite sumarizar os resultados de pesquisas consolidadas e extrair conclusões globais de um corpo de literatura disponível acerca de um tópico em particular - no caso, o apoio e as redes sociais no contexto dos TA. Dessa forma, as evidências encontradas a partir da realização da revisão integrativa permitiram o aprofundamento do tema tratado no presente capítulo, e também no próximo. A seguir, assim como no capítulo 4, será feita uma apresentação dos resultados provenientes dos estudos mais relevantes selecionados e analisados na revisão integrativa.

Um dos artigos encontrados na revisão (Limbert, 2010) pontua que, atualmente, não se sabe exatamente de que forma o apoio social influencia os TA. A autora sugere que a percepção de ser aceito pelos membros do meio imediato do qual o indivíduo faz parte tem a função, dentre outras, de evitar a ocorrência ou o agravamento do quadro. O contrário também é válido: a ausência de apoio da família e dos amigos serve como fator predisponente para o desenvolvimento de sentimentos negativos em relação ao próprio corpo, despertando no sujeito a crença de que seria mais popular se perdesse peso.

As características de personalidade que marcam os indivíduos acometidos por TA geralmente dificultam o fornecimento de apoio social por parte das pessoas de suas redes sociais significativas. Dentre elas, inclui-se o sigilo a respeito da quantidade de alimento consumida, da utilização de métodos de purgação e do total de peso perdido. Esse sigilo impede o estabelecimento de relações de confiança e resulta em dificuldades tanto para o indivíduo acometido - que não consegue procurar ajuda quando necessita - quanto para os membros das redes sociais, que não percebem abertura para fornecer ajuda (Limbert, 2010).

A literatura específica acerca do tema dos TA engloba uma quantidade significativa de estudos que apontam para a rede social familiar como sendo a principal fonte de apoio aos indivíduos acometidos por esses quadros (Dimitropoulos, Carter, Schachter, \& Woodside, 2008; Kluck, 2008; Limbert, 2010; Marcos \& Cantero, 2009). Segundo Marcos e Cantero (2009), dentre os membros da família, a mãe e o cônjuge são consideradas as principais fontes de apoio social de mulheres com TA, e essas mulheres encontram-se satisfeitas com o apoio recebido por meio 
da rede familiar. Em contrapartida, Limbert (2010) aponta para uma relação entre a insatisfação com o apoio social recebido da rede familiar e os sintomas de TA. A família, por configurar a rede social mais discutida pela literatura extraída da revisão integrativa realizada, será abordada de forma mais ampla no capítulo seguinte.

No entanto, apesar de a família emergir cada vez mais na literatura especializada como sendo a fonte de apoio mais significativa dos pacientes com TA, nota-se uma lacuna no que concerne ao apoio recebido e percebido de outras redes sociais, tais como amigos, colegas de trabalho e estudo, organizações religiosas, instituições de saúde, entre outros. Segundo Shomaker e Furman (2009), as relações interpessoais na adolescência podem predispor o indivíduo a desenvolver comportamentos alimentares disfuncionais nessa época, uma vez que há uma pressão significativa por parte dos amigos para que as adolescentes sejam magras. Além disso, as críticas sobre a aparência também parecem ser constantes na adolescência, despertando sentimento de menos valia e, consequentemente, o desejo de emagrecer. Sweetingham e Waller (2008) também comprovaram que há uma relação específica entre as experiências de bullying, as provocações dos colegas sobre aparência física e a insatisfação com o corpo, que era mediada pela vergonha.

Ainda considerando o papel das redes de amizade na adolescência e a influência dessas redes sobre o quadro de TA, Hutchinson e Rapee (2007) demonstram que amigas que fazem parte de "panelinhas" compartilham pontuações semelhantes nos instrumentos de avaliação de comportamentos alimentares disfuncionais. Esse estudo indica que a percepção dos colegas em relação às atitudes e comportamentos relacionados à alimentação exerce influência significativa sobre a preocupação das adolescentes com sua imagem corporal, podendo levar à realização de dietas e aos comportamentos extremos para perda de peso ou, em contrapartida, à compulsão alimentar.

Custódio (2010) sugere as crenças e práticas religiosas como possíveis fontes de apoio social. A autora coloca que a inserção nessas redes e a utilização da espiritualidade podem servir de apoio no enfrentamento e o tratamento de doenças. Ao colaborar com uma mudança na perspectiva que o indivíduo acometido possui da doença, as práticas religiosas possibilitam um alívio do sofrimento.

A participação em websites e fóruns online também surgiu como importante fonte de apoio para mulheres jovens e adultas acometidas por TA. Cinco dos artigos selecionados na revisão integrativa da literatura buscaram investigar características de websites pró-TA e das 
pessoas que fazem uso desses sites. Borzekowski, Schenk, Wilson e Peebles (2010) notaram que esses sites apresentam materiais gráficos e recursos interativos que encorajam, apóiam e motivam os usuários a manter seus comportamentos anoréxicos e bulímicos, tais como: imagens de modelos esquálidas, contagem diária de alimentos e de calorias, além de dicas de dietas. Os temas comuns discutidos nos websites foram: sucesso, controle, perfeição e solidariedade. Os autores também notaram que apenas 38\% dos sites incluíam informações ou links de orientação para a recuperação. Mulveen e Hepworth (2006) identificaram quatro eixos de temas discutidos nesses sites: (1) dicas e técnicas; (2) 'ana' (AN como opção de vida) versus AN (quadro psiquiátrico); (3) apoio social; e (4) necessidade da AN. Os resultados deste estudo sugerem que a participação nos sites apresenta inúmeros propósitos, principalmente o de oferecer ajuda no enfrentamento de problemas relacionados à grave perda de peso e o de ser um espaço para elaboração de conteúdos emocionais difíceis.

Por sua vez, o estudo de Ransom, LaGuardia, Woody e Boyd (2010) também trouxe achados que demonstraram que esses sites pró-TA encorajam os comportamentos restritivos e bulímicos, o que pode contribuir para o aumento e agravamento dos quadros de TA. Ao recolher informações dos usuários dos sites por meio da troca de emails, esses usuários relataram receber mais apoio para os outros fatores estressores de sua vida do que para as suas preocupações relacionadas à alimentação. Também relataram que recebem menos apoio em seus relacionamentos off-line, ou seja, interações com pessoas do meio em que vivem, do que das pessoas que conhecem on-line, tanto para suas preocupações gerais quanto para suas dificuldades alimentares.

Os achados do estudo de Csipke e Horne (2007) foram convergentes com os estudos já descritos, uma vez que levaram à conclusão de que os membros dos sites sentem que recebem menos apoio em suas relações significativas do que seus colegas e pares, e procuram participar de fóruns on-line como um meio para receberem maior apoio social. Os usuários também relataram melhora no estado psicológico depois de visitarem os sites. Foram encontradas evidências de redução do impacto de conteúdos potencialmente prejudiciais para usuários desses sites. No entanto, apesar do apoio social fornecido por meio dos websites pró-TA, Brotsky e Giles (2007) sugerem que esses sites são melhor compreendidos como locais que oferecem um alívio temporário da hostilidade proveniente de pessoas do meio ambiente real (off-line), e não se pode dizer que possuem um valor terapêutico para além do contexto on-line. 
Vale ressaltar que outra rede social importante, principalmente no contexto da saúde, é a rede social institucional. Trata-se da rede de apoio que é oferecida pelos serviços de saúde disponíveis na instituição hospitalar (Custódio, 2010). Nos casos de TA, a rede social institucional geralmente é configurada como uma equipe multidisciplinar, cujo quadro de profissionais deve englobar: psicólogos, psiquiatra, médico nutrólogo, enfermeiras, entre outros. O objetivo do tratamento deve ser a prevenção e a intervenção precoce, além do fornecimento de informações acerca do TA ao público e aos cuidadores de indivíduos acometidos por esses transtornos (McMaster, Beale, Hillege, \& Nagy, 2004).

A terceira edição do Manual de Tratamento de Pacientes com Transtornos Alimentares (Associação Americana de Psiquiatria, 2006) afirma que a escolha do ambiente/local no qual o tratamento deve ser oferecido é condicionada pelas diversas possibilidades de assistência existentes, mas a escolha recai, preferencialmente, no ambiente hospitalar. O tratamento pode variar da hospitalização integral (internação), quando o paciente necessita de cuidados médicos, até o atendimento ambulatorial, com atendimento médico, nutricional, psicológico (individual ou grupal) e terapia familiar. No referido Manual também é proposto que a determinação do plano de atendimento de cada paciente deve levar em conta a sua condição clínica, psicológica e social, e não apenas os parâmetros antropométricos, tais como o peso e o Índice de Massa Corporal (IMC). Quando necessária, a internação deve focar principalmente, os riscos físicos apresentados, realizando-se intervenções legais para a hospitalização involuntária de pacientes em risco iminente de morte.

A equipe multidisciplinar é ser considerada como fonte de apoio significativa não apenas aos pacientes, mas também aos familiares (Hillege, Beale, \& McMaster, 2006), que sofrem inúmeros efeitos negativos decorrentes do fato de ter na família um membro acometido por um TA. Dentre esses efeitos, incluem-se: desintegração dos laços familiares, dificuldade de enfrentamento e isolamento social. Considera-se que a participação dos familiares no tratamento contribui para a diminuição do estresse proveniente dos efeitos negativos mencionados e, consequentemente, para a melhora da qualidade de vida desses familiares.

Levando-se em conta que os resultados da revisão integrativa realizada acerca do tema do presente estudo demonstraram que a família configura a rede social mais importante das mulheres acometidas por TA, o capítulo a seguir irá tratar do funcionamento e da dinâmica das famílias com um membro afetado por esses quadros. 


\section{Capítulo 4. Transtornos alimentares e relações familiares}

Estudos apontam para a influência familiar nos TA, partindo da hipótese de que as famílias com um membro com $\mathrm{AN}$ ou BN compartilham características de funcionamento semelhantes. Acredita-se na existência de uma estreita relação entre o funcionamento familiar e a emergência ou perpetuação do transtorno (Souza \& Santos, 2006). Pode-se mencionar, por exemplo, o modelo de "famílias psicossomáticas", criado por Minuchin et al. (1975), que preconizam que algumas características do funcionamento familiar influenciam no aparecimento de determinados quadros psicopatológicos. Esse modelo inspirou a concepção de "famílias anorexígenas", ou seja, a família como ponto de origem das perturbações alimentares dos filhos (Souza \& Santos, 2006).

Apesar da literatura específica ser consistente a respeito da relação entre apoio social e TA, há diferenças entre os cenários familiares nos casos de $A N$ e BN e, consequentemente, entre o tipo de apoio fornecido por essas famílias (Limbert, 2010). Indivíduos acometidos por AN costumam fazer parte de famílias com laços muito estreitos e fronteiras indiferenciadas, que dificultam a separação dos membros. Além disso, essas famílias também apresentam uma tendência a evitar conflitos explícitos e possuem altas expectativas em relação uns aos outros. Em contrapartida, os familiares de indivíduos com BN apresentam altos níveis de conflitos e desarmonia parental. Os pais desses indivíduos geralmente são percebidos como distantes, negligentes e críticos.

No que concerne à satisfação com o apoio recebido da rede familiar, as pessoas acometidas por quadros de BN demonstram níveis mais altos de insatisfação, enquanto que as pessoas com AN costumam relatar maior satisfação. Pode-se considerar que as diferenças mencionadas refletem variados níveis de expectativa em relação ao recebimento de apoio, mas não indicam diferenças quanto ao apoio efetivamente fornecido aos dois grupos (Limbert, 2010).

Segundo Bryant-Waugh e Lask (1995), a desarmonia familiar, a separação do casal e a falta de consistência na resposta dos pais ao transtorno do filho podem ser considerados fatores mantenedores do quadro psicopatológico. Outros autores (Lane, 2002; Soenens et al., 2008) acrescentam ainda que indivíduos com TA proveem de lares com mães controladoras, perfeccionistas e pais ausentes, além de estarem frequentemente expostos a histórias de traumas que permeiam os enredos familiares. 
Dallos e Denford (2008) sugerem que os relacionamentos dentro das famílias com um membro acometido por um TA se dão sobre uma base falsa ou frágil, com predomínio de vínculos problemáticos, discussões frequentes, triangulação, desconforto e relação negativa com a alimentação. Os autores também pontuam que as experiências de relacionamentos conflituosos e padrões de comunicação confusos são comuns entre os membros dessas famílias. A significativa proporção de regras restritivas implícitas que permeiam a convivência entre os membros dessas famílias também parece estar relacionada à precipitação do TA, uma vez que os indivíduos acometidos por esses quadros percebem que seus pais tendem a restringir seus comportamentos, dificultando o diálogo e a expressão de sentimentos afetuosos, o que resulta em pensamentos e sentimentos restritivos, pouca expressividade emocional e dificuldade de simbolização por parte do membro acometido (Gillet, Larson, \& Hardman, 2009).

A triangulação, descrita por Dallos e Denford (2008) como fenômeno bastante presente nas relações familiares de indivíduos com TA, é também considerada como um dos temas mais importantes no estudo das dinâmicas familiares em geral. Trata-se de conjuntos de relações entre três pessoas, nas quais o funcionamento de uma depende e influencia o comportamento das outras duas. A configuração das triangulações nas famílias envolve duas pessoas unidas em relação a uma terceira, e tem o objetivo de diminuir a tensão existente entre a dupla. Considera-se que, para que um indivíduo tenha um desenvolvimento saudável, é necessário que haja diferenciação entre os membros da família, que diz respeito à capacidade de agir e tomar decisões por conta própria, independentemente das relações estabelecidas com outras pessoas (McGoldrick, Gerson, \& Petry, 2008).

No caso dos TA, as relações familiares apresentam padrões típicos de ansiedade, ambivalência e preocupação excessiva, principalmente na relação entre mãe e filha, que costuma implicar na exclusão de um terceiro - o pai -, caracterizando a triangulação. Dallos e Denford (2008) sugerem que mulheres acometidas por esses quadros vivenciam sensações frequentes de conflitos reais ou iminentes entre os pais, além de se sentirem presas no centro desses conflitos e serem coagidas a tomar partido de um dos genitores. Hipotetiza-se que a relação de superenvolvimento entre mãe e filha seja reflexo de tensões implícitas na relação do casal, que se encontram encobertas pelo TA da filha. Dessa forma, pode-se considerar que o quadro psicopatológico funciona como uma "distração" para os pais de seus próprios conflitos (McGoldrick, Gerson, \& Petry, 2008). 
McNamara e Loveman (1990), buscando compreender a dinâmica interativa nas famílias de pacientes com BN, pontuam que as adolescentes que desenvolvem esse quadro percebem suas famílias como mais disfuncionais do que as pessoas das famílias controle. Segundo esses autores, as famílias de pacientes bulímicas apresentam pouco afeto entre seus membros, pouca comunicação e escassa habilidade para a resolução de conflitos. Esses resultados, segundo os autores, sugerem que essas jovens não aprenderam apropriadamente como controlar os seus impulsos e, dentro de uma atmosfera caótica e de pouca afetividade, buscam a comida como forma de obtenção de gratificação.

Wertheim et al., (2002), em estudo realizado com o objetivo de identificar a transmissão de valores de pais para filhos relacionados à alimentação e ao peso, pontuam que o desejo de emagrecer e a insatisfação com o corpo parecem estar relacionados com o encorajamento, por parte de um dos pais, para a realização de dietas. Esse encorajamento, principalmente por parte das mães, acontece independentemente do peso e altura dos filhos. Kluck (2008) também sugere que tanto a dinâmica familiar disfuncional quanto as experiências familiares negativas relacionadas à alimentação estão relacionadas com o aumento da alimentação disfuncional das filhas acometidas pelo TA. Essa autora indica a necessidade de mudanças na prática clínica, no sentido de incluir a família no tratamento, focando a dinâmica familiar e a relação entre pais e filhas com TA.

Abreu e Filho (2004) caracterizam as trocas parentais nas famílias de pacientes com TA como sendo, na maioria das vezes, marcadas por baixos níveis de cumplicidade e respeito interpessoal. Trata-se de famílias perturbadas, mal organizadas e com dificuldade de expressão de afeto e cuidado. Na medida que a instabilidade ambiental se torna algo fixo, a falta de valores mais solidificados torna o esmero pessoal um elemento primordial na definição da identidade incompleta dessas mulheres, que passam a buscar a perfeição por meio do corpo (Abreu \& Filho, 2004).

Dimitropoulos et al. (2008) sugerem que os familiares que constituem a rede familiar de mulheres com TA sofrem de intensa sobrecarga, que diz respeito à conflitos relacionados ao papel de cuidador, ao estigma que a família carrega em função do transtorno e das atitudes negativas de membros da família extensa em relação à pessoa acometida. 0 reagrupamento ou desintegração familiar, a incapacidade dos pais de enfrentamento de situações negativas, o isolamento social e os impactos financeiros também são considerados como efeitos do TA sobre a vida familiar (Limbert, 2010). Acredita-se que essas dificuldades 
podem comprometer a saúde mental dos familiares de mulheres com TA, reduzindo o potencial de apoio da rede familiar e comprometendo, por sua vez, o bem estar dessas mulheres. A cronicidade do quadro psicopatológico das filhas parece demandar um número muito alto de horas de dedicação por parte dos familiares, o que acaba causando uma sobrecarga, que compromete sua saúde mental e, consequentemente, sua capacidade de oferecer cuidados apropriados (Winn et al., 2007).

Alguns autores sugerem que a origem dos TA encontra-se intimamente associada à relação entre mãe e filha acometida (Brusset, 2003). A respeito dessa relação, Sopezcki e Vaz (2008) realizaram um estudo no qual considerou-se a relação mãe-filha e a autoestima rebaixada da filha como fatores de risco para a precipitação e manutenção dos TA. Os autores conduziram uma revisão da literatura acerca desses construtos, cujos resultados sugeriram que as mães de adolescentes com TA tendem a enxergar suas filhas como parte inerente de si mesmas, devido a componentes narcisistas que prevalecem na relação da dupla, tais como identificação e simbiose, com resultam em uma indiferenciação das duas. A formação da autoestima adequada depende intimamente do olhar amoroso de apreciação por uma pessoa significativa, a mãe, pois não é com seus próprios olhos que a criança se vê, mas sempre a partir dos olhos do outro. O ver-se, em um processo de identificação com esse olhar dirigido para si, constitui o narcisismo, base de sua própria autoestima. Dependendo do tipo de apego predominante na dupla, a autoestima da filha terá nuances diferenciadas. Considera-se, então, que o tipo de relação estabelecida com a mãe pode influenciar no desenvolvimento da autoestima da filha que, por sua vez, pode ter influência na precipitação do TA.

Ainda a respeito da relação mãe e filha, Cooley, Toray, Wang e Valdez (2008) buscaram examinar os efeitos dos comportamentos e atitudes alimentares das mães, dos comentários maternos a respeito dos problemas de peso da filha, do grau de proximidade no relacionamento entre mãe e filha, da influência da mídia e das percepções maternas a respeito da imagem corporal e da psicopatologia alimentar das filhas. Observou-se que a imagem corporal das filhas sofria influências: do feedback negativo da mãe, da desaprovação materna da forma corporal das filhas e do modo como os comportamentos e atitudes alimentares das mães eram percebidos por elas. A influência materna pôde ser melhor avaliada utilizando-se a percepção que as filhas tinham de suas mães, pois essa percepção correspondia ao que a filha conseguia captar das atitudes e comportamentos alimentares de suas mães. O feedback materno negativo 
sobre a forma corporal e os padrões alimentares de suas filhas foi considerado fator crucial no aumento significativo das dificuldades das filhas nessas questões. As mães que mostraram maior internalização das mensagens da mídia a respeito da magreza apresentaram maior probabilidade de ter filhas com patologias alimentares.

Poucos estudos disponíveis na literatura abordam o papel dos irmãos nos casos de TA. Honey et al. (2006) sugerem que os irmãos podem exercer tanto influência positiva quanto negativa sobre o quadro psicopatológico da irmã acometida. Essa influência pode se dar por meio da presença ativa dos irmãos na família, das diversas formas de reagir ao transtorno e do impacto que eles exercem também sobre os pais. Uma série de fatores pode afetar a influência dos irmãos, incluindo: a compreensão que eles possuem a respeito da $\mathrm{AN}$, estilos de vida, o tipo de relacionamento que predominava antes da $\mathrm{AN}$, se os pais e a filha acometida estimularam ou não o envolvimento do irmão com o transtorno, características do irmão e da família, bem como intervenções profissionais. Areemit, Katzman, Pinhas e Kaufman (2010) pontuam que a qualidade de vida de irmãos de mulheres com TA é, geralmente, afetada de forma bastante negativa pelo transtorno. Os autores apontam para os seguintes efeitos do TA sobre os irmãos: desejo de compreender o TA, consciência dos comportamentos e pensamentos típicos do quadro, dificuldade na compreensão dos comportamentos obsessivos não relacionados ao quadro, aumento dos conflitos familiares, compaixão e preocupação pela irmã acometida, sentimento de perda e sacrifício, senso opressivo de responsabilidade pela irmã e uma sensação de onipresença do TA em todos os aspectos de suas vidas.

No que concerne à percepção que as próprias mulheres com TA têm de suas famílias, Cunha, Relvas e Soares (2009) apontam que elas perceberam suas famílias como pouco coesas e incapazes de redefinirem eventos estressantes a fim de torná-los mais manejáveis. No entanto, os autores também sugerem que as pacientes percebem suas famílias como sendo capazes de adquirir e aceitar ajuda, e apresentam crenças familiares relacionadas a um senso de responsabilidade individual e autoculpabilização. Além disso, as pacientes parecem confiar menos em suas mães e pares, comunicar-se menos com estes e demonstrar menos apego às mães, pais e colegas.

Apesar das evidências existentes de que o funcionamento familiar é um componente crucial na produção de contextos favoráveis à emergência dos TA, poucos estudos disponíveis nesse campo abordam a questão da percepção que a própria paciente possui das suas redes familiar, social e pessoal, as repercussões que esse quadro sintomatológico 
acarreta nesses contextos específicos e as possíveis relações que podem existir entre essas redes e a manutenção ou superação do transtorno.

Além do funcionamento familiar em si, a literatura aponta que eventos estressores ocorridos dentro do ambiente familiar também podem estar relacionados com comportamentos alimentares disfuncionais e formas não saudáveis de controle de peso, que surgem como modo de lidar ou reduzir as emoções negativas (Berge et al., 2011). Tais eventos podem englobar: divórcio dos pais; morte de um membro da família; mudança de escola, casa ou trabalho dos pais; surgimento de uma doença em algum membro ou hospitalização; violência ou abuso sexual; incesto. A ocorrência desses eventos transicionais no ciclo de vida de uma família não costuma ser acompanhada do apoio social necessário para que os membros possam superá-los. Assim, a ausência de apoio social intensifica as dificuldades emocionais vivenciadas e pode levar à precipitação do TA (Berge et al., 2011).

Os TA configuram uma categoria psicopatológica ainda cercada por amplo desconhecimento por parte da população em relação às suas características, evolução e tratamento, o que acaba gerando incompreensão por parte dos familiares, amigos, professores e colegas de trabalho. Por ser uma condição crônica estigmatizante, esse desconhecimento incrementa o isolamento social, aumentando os sentimentos de solidão e desamparo do indivíduo acometido. Por essa razão, ao planejar o cuidado a esses pacientes, é fundamental que os profissionais conheçam sua rede social e o apoio percebido (Filho \& Nóbrega, 2004; Resende et al., 2006).

Considerando esses pressupostos, acredita-se que a constituição da identidade pessoal do sujeito se dá no espaço intersubjetivo das relações familiares, sociais e pessoais, e no contato com as diversas redes as quais ele é exposto no decorrer do ciclo vital. Partindo-se da hipótese de que as relações que as mulheres com TA estabelecem ao longo de sua vida são bastante conturbadas e fragilizadas, marcadas por conflitos e por dificuldades no estabelecimento de vínculos consistentes (Abreu \& Filho, 2004; Oliveira \& Santos, 2006; Peres \& Santos, 2006), pode-se pensar que as redes sociais dessas mulheres são marcadas por pouco envolvimento dos membros e baixa qualidade dos vínculos, o que comprometeria o potencial de apoio e o próprio desenvolvimento da identidade do indivíduo. A baixa efetividade das redes e o comprometimento do apoio social disponibilizado a essas mulheres podem agravar a ocorrência do TA, intensificando a cronicidade do quadro psicopatológico. 


\section{OBJETIVOS}

\subsection{Objetivo Geral}

Investigar o modo como se configuram as redes sociais de mulheres com diagnóstico de TA, assim como o apoio social percebido por elas e suas possíveis implicações para a evolução do quadro psicopatológico.

\subsection{Objetivos Específicos}

a) descrever as características sociodemográficas e clínicas das participantes;

b) caracterizar os aspectos psicossociais que afetam o quadro psicopatológico;

c) identificar os padrões de relação que as participantes estabelecem com as pessoas de seu meio, assim como a dinâmica das relações familiares;

d) investigar a configuração da rede social significativa dessas mulheres;

e) analisar, na perspectiva das participantes, as repercussões do TA sobre as redes nas quais elas estão inseridas;

f) identificar as principais redes de apoio social das participantes e a percepção que elas possuem do apoio recebido. 


\section{MÉTODO}

\subsection{Delineamento da pesquisa}

O presente estudo foi desenvolvido segundo um enfoque qualitativo de pesquisa, que se propõe a investigar em profundidade um determinado tema e se preocupa com o nível de realidade que não pode ser quantificado, ou seja, trabalha com o universo de significados, motivos, aspirações, expectativas, crenças, valores e atitudes (Minayo, 1994). Nesse sentido, Maykut e Morehouse (1994) definem a pesquisa qualitativa como uma abordagem flexível, que apreende a complexidade e a subjetividade nas narrativas das experiências humanas, incluindo sentimentos, pensamentos e emoções.

Foi adotado também o delineamento de pesquisa descritivo e exploratório, uma vez que o objetivo do presente estudo envolveu, de modo geral, a descrição e a caracterização das vivências de mulheres com TA imersas em suas redes sociais. Além disso, o estudo teve a finalidade de identificar e analisar conceitos e ideias presentes nos discursos das participantes, procurando esclarecer os sentidos e significados envolvidos (Gil, 1991). O delineamento da pesquisa também pode ser caracterizado como transversal, já que as participantes foram abordadas em um momento específico da sua trajetória de vida, ainda que esse momento esteja inserido em um contexto mais amplo (Polit, Becker, \& Hungler, 2004).

\subsection{Caracterização do campo de pesquisa}

A realização da coleta de dados do presente estudo se deu no Grupo de Assistência em Transtornos Alimentares - GRATA. Trata-se de um serviço organizado por uma equipe multidisciplinar de saúde inserida na Clínica de Nutrologia do Hospital das Clínicas da Faculdade de Medicina de Ribeirão Preto (HC-FMRP-USP).

O GRATA tem como objetivo geral oferecer tratamento a indivíduos acometidos por TA na cidade de Ribeirão Preto e região. Esse tratamento envolve: grupos de apoio psicológico e de orientação nutricional, tanto aos pacientes quanto aos familiares; acompanhamento nutricional, médico, psiquiátrico e psicológico aos pacientes; psicoterapia aos familiares; reuniões semanais da equipe multidisciplinar para discussão e tomadas de decisões a respeito dos casos em seguimento, leitura de artigos científicos e apresentação 
das pesquisas realizadas dentro do serviço. O quadro de profissionais que compõem o GRATA atualmente engloba:

- quatro psicólogos: um responsável pela subequipe de Psicologia do serviço e uma supervisora, sendo que os dois também coordenam o grupo de apoio psicológico aos pacientes, e duas psicólogas que coordenam os grupos de apoio psicológico aos familiares, participam do acolhimento e realizam entrevistas psicológicas com os pacientes ingressantes;

- quatro estagiárias do curso de Psicologia, que realizam atendimentos psicoterápicos individuais, consultas psicológicas e participam como observadoras participantes dos grupos;

- quatro nutricionistas: uma responsável pela subequipe de Nutrição do serviço, uma supervisora e duas que realizam atendimentos individuais, participam do acolhimento e realizam entrevistas nutricionais com os pacientes ingressantes;

- duas estagiárias do curso de Nutrição, que observam os grupos de orientação nutricional oferecido aos pacientes e os atendimentos nutricionais individuais;

- dois médicos nutrólogos: um fundador do serviço, responsável pela coordenação, e uma médica residente em Nutrologia, que realiza os atendimentos individuais, bem como a avaliação clínica dos pacientes ingressantes;

- uma psiquiatra, que oferece atendimento psiquiátrico individual, bem como participa do acolhimento e realiza entrevistas com os pacientes ingressantes, além de coordenar o grupo de orientação clínica aos familiares.

No período de realização do estudo a pesquisadora exerceu a função de psicóloga voluntária do GRATA. Encontrava-se vinculada ao serviço desde 2007, quando, na condição de aluna de graduação, realizou sua pesquisa de iniciação científica. Pelo fato de a pesquisadora fazer parte da equipe permanente do serviço e já ter contato prévio com pacientes e familiares, não foi necessária a imersão no campo como etapa preparatória das entrevistas.

Durante o período da coleta de dados do presente estudo, o quadro de pacientes em seguimento no GRATA era composto por 21 pacientes, todas do sexo feminino, sendo que 12 foram incluídas como participantes nesta pesquisa e serão caracterizadas a seguir. Das nove pacientes restantes, seis tinham recebido diagnóstico de AN do tipo restritivo e três haviam sido diagnosticadas com TA não especificado. A idade das pacientes variou entre 49 e 15 anos, sendo a idade média correspondente a 22,6 anos. Em termos de escolaridade, 
três tinham Ensino Médio completo, duas tinham Ensino Médio incompleto, três estavam cursando a universidade (ou seja, tinham Ensino Superior incompleto) e apenas uma havia completado o Ensino Superior. Seis das pacientes em seguimento eram estudantes, uma era educadora, uma era enfermeira (aposentada) e uma massagista. Apenas uma era casada. Por fim, o tempo de tratamento das pacientes no GRATA no período de duração da pesquisa variou entre três meses e 23 anos.

\subsection{Participantes}

A amostra do presente estudo foi constituída por critérios de conveniência. Como critérios de inclusão na amostra estabeleceu-se que as participantes fossem do sexo feminino e apresentassem TA com sintomas bulímicos ${ }^{3}$, independentemente do diagnóstico específico, faixa etária, grau de escolaridade, estado civil, tempo de acometimento e comorbidade psiquiátrica. Também foram aplicados alguns critérios de exclusão, de forma a se evitar perda de informação em decorrência do status das informantes. Foram eles:

- evidência de prejuízo grave na linguagem ou comunicação;

- déficit sensorial (audição) ou cognitivo, que prejudicasse a comunicação e a compreensão da tarefa;

- paciente em regime de alta do serviço.

Participaram do estudo 12 mulheres com TA, que se encontravam em seguimento no GRATA durante o período da coleta de dados, ou seja, de abril a dezembro de 2010. Como exposto na Tabela 2, a idade média das participantes corresponde a 27,7 anos. Oito delas apresentavam diagnóstico de AN do tipo purgativo e quatro apresentavam BN. Os dados

\footnotetext{
${ }^{3}$ Como já explicitado no Capítulo 1 - Delineando os quadros clínicos - do presente estudo, a literatura específica acerca dos TA apresenta significativas diferenças diagnósticas entre os quadros de BN e AN. De modo geral, a primeira é caracterizada pelo excesso, pela impulsividade e ausência de controle (Vindreau, 2003), que são direcionados para a relação com o alimento, resultando em episódios de compulsão alimentar e rituais compensatórios e purgativos. A AN, por sua vez, é marcada pela falta e pelo controle excessivo, que também se expressa na conduta alimentar, por meio da recusa e evitação do alimento (Cassin \& Von Ransom, 2005; Oliveira \& Santos, 2006). Entretanto, apesar das diferenças diagnósticas mencionadas, a prática na área dos TA frequentemente evidencia que os pacientes apresentam sintomas mistos dos dois quadros (Schmidt \& Mata, 2008). Segundo o DSM-IV-TR ${ }^{\text {TM }}$ (Associação Americana de Psiquiatria, 2002), a AN pode ser dividida em dois subtipos: AN do tipo restritivo e do tipo purgativo. O segundo subtipo inclui episódios de restrição, alternados com episódios de compulsão e purgação alimentar, acompanhados da sensação de perda de controle, típicos do quadro de BN. Tendo em vista essa aproximação entre os sintomas clínicos e psicológicos da BN e da AN do tipo purgativo, e visando aumentar a amplitude da amostra selecionada neste estudo, optouse pela inclusão de participantes que apresentavam um dos dois quadros: BN ou AN do tipo purgativo.
} 
antropométricos expostos na Tabela 2 foram obtidos a partir de consultas aos prontuários hospitalares das participantes. Para impedir a identificação das participantes, os nomes próprios foram substituídos por nomes fictícios.

Tabela 2. Caracterização das participantes segundo o diagnóstico, peso, altura, IMC na admissão e no momento da avaliação, e tempo de tratamento no serviço

\begin{tabular}{|c|c|c|c|c|c|c|c|}
\hline Participantes & $\begin{array}{l}\text { Idade } \\
\text { (anos) }\end{array}$ & Diagnóstico & $\begin{array}{c}\text { Peso } \\
\text { (kg) }\end{array}$ & $\begin{array}{c}\text { Altura } \\
(\mathrm{m})\end{array}$ & $\begin{array}{c}\text { IMC de } \\
\text { admissão } \\
\left(\mathrm{kg} / \mathrm{m}^{2}\right)\end{array}$ & $\begin{array}{c}\text { IMC atual } \\
\left(\mathrm{kg} / \mathrm{m}^{2}\right)\end{array}$ & $\begin{array}{c}\text { Tempo de } \\
\text { tratamento no } \\
\text { serviço } \\
\text { (meses) }\end{array}$ \\
\hline Maria & 30 & $\begin{array}{l}\text { AN do tipo } \\
\text { purgativo }\end{array}$ & 49,1 & 1,64 & 17,8 & 18,3 & 22 \\
\hline Grazieli & 20 & BN & 59,3 & 1,65 & 23,5 & 21,9 & 10 \\
\hline Sissi & 27 & $\mathrm{BN}$ & 63,4 & 1,75 & 21,2 & 20,6 & 12 \\
\hline Sofia & 27 & $\begin{array}{l}\text { AN do tipo } \\
\text { purgativo }\end{array}$ & 44,1 & 1,72 & 14,7 & 14,9 & 6 \\
\hline Bárbara & 24 & $\begin{array}{l}\text { AN do tipo } \\
\text { purgativo }\end{array}$ & 56,4 & 1,60 & 21,9 & 21,9 & 1 \\
\hline Carolina & 31 & $\mathrm{BN}$ & 101,3 & 1,65 & 36,1 & 37,2 & 84 \\
\hline Fernanda & 40 & $\begin{array}{l}\text { AN do tipo } \\
\text { purgativo }\end{array}$ & 70,8 & 1,74 & 16,7 & 23,2 & 184 \\
\hline Amanda & 22 & $\begin{array}{l}\text { AN do tipo } \\
\text { purgativo }\end{array}$ & 50,8 & 1,66 & 17,3 & 18,4 & 48 \\
\hline Juliana & 30 & $\begin{array}{l}\text { AN do tipo } \\
\text { purgativo }\end{array}$ & 53,3 & 1,67 & 20,4 & 19,1 & 168 \\
\hline Marina & 29 & BN & 60,7 & 1,69 & 20,0 & 21,5 & 60 \\
\hline Estrelinha & 28 & $\begin{array}{l}\text { AN do tipo } \\
\text { purgativo }\end{array}$ & 47 & 1,71 & 15,9 & 15,9 & 1 \\
\hline Ana & 24 & $\begin{array}{l}\text { AN do tipo } \\
\text { purgativo }\end{array}$ & 40,6 & 1,52 & 15,7 & 17,5 & 60 \\
\hline
\end{tabular}

A amostra do presente estudo corresponde a $57,14 \%$ do total de pacientes que se encontravam em seguimento regular junto ao GRATA no período da coleta de dados. 


\subsection{Pré-teste dos instrumentos}

O pré-teste consistiu na aplicação do protocolo de pesquisa com uma participante. Por meio deste, objetivou-se que os instrumentos utilizados e o procedimento de coleta de dados fossem testados quanto à clareza, compreensibilidade, ordenação das questões e precisão da linguagem. Para alcançar esses objetivos, recrutou-se uma paciente que se encontrava em seguimento no GRATA e que preenchia os critérios de inclusão da pesquisa.

A abordagem inicial da participante consistiu na apresentação dos objetivos da pesquisa e no convite para que ela colaborasse com a mesma. Mediante anuência da participante, verificou-se sua disponibilidade e agendou-se um horário para que a entrevista fosse realizada no próximo retorno da participante ao serviço ambulatorial.

Ao aplicar-se o protocolo de pesquisa, notou-se que a entrevista teve duração média de 60 minutos, e que a participante não demonstrou incômodo com esse tempo, nem deu sinais de estar cansada. Também foi possível notar que a participante compreendeu todas as questões da entrevista e os objetivos dos instrumentos.

Dessa forma, verificou-se a adequação do roteiro de entrevista, assim como dos instrumentos aplicados. Considerando-se essa adequação, os instrumentos e procedimentos de coleta de dados previamente definidos não foram alterados. O material coletado por meio do relato da participante do pré-teste integrou os resultados da presente pesquisa.

\subsection{Instrumentos}

Foram utilizados os seguintes instrumentos para a coleta de dados: a) entrevista semi-estruturada; b) Mapa de Redes; c) Genograma; d) Critério de Classificação Econômica Brasil/2010. É importante ressaltar que o Genograma e o Mapa de Redes foram utilizados em função da potencialidade gráfica que possuem, que possibilita melhor integração das informações oriundas dos discursos das participantes nas entrevistas (Santos, 2009). De forma a complementar os dados oriundos da aplicação dos instrumentos utilizados, foram também realizadas consultas aos prontuários hospitalares das participantes. Essas consultas tiveram o objetivo de extrair informações acerca de dados sociodemográficos das participantes, que podem ter permanecido interrogados nas entrevistas. Além disso, procurou-se também obter os dados antropométricos (diagnóstico, peso, altura, IMC e tempo de tratamento) das participantes. 


\subsubsection{Entrevista semi-estruturada}

A técnica de entrevista semi-estruturada foi utilizada no presente estudo por permitir o aprofundamento em determinado tema de pesquisa, indo além de uma conversa superficial para uma rica discussão a respeito de pensamentos e sentimentos (Maykut \& Morehouse, 1994). Em se tratando de uma relação entre duas pessoas (entrevistador e entrevistado), a entrevista pode ser compreendida como um diálogo dinâmico e mútuo, no qual ocorrem interações e trocas entre as partes, e de onde podem surgir os sentidos e significados para o indivíduo da experiência investigada.

Essa modalidade de coleta de dados implica em compor um roteiro de perguntas elaboradas de forma a atender os objetivos da investigação, adotando uma formulação flexível, de modo que a sucessão das questões e os detalhes deverão ficar por conta do discurso das participantes e da dinâmica da entrevista. O entrevistador introduz o tema e o entrevistado tem liberdade para discorrer sobre ele, podendo assim explorar amplamente a questão. As perguntas são respondidas dentro de uma conversação informal, na qual a interferência do entrevistador deve ser a mínima possível (Minayo, 1994).

O roteiro da entrevista semi-estruturada deste estudo (Apêndice 1) foi constituído pelos seguintes temas: 1) Dados sociodemográficos; 2) Informações acerca do TA; 3) Informações relativas ao tratamento; 4) Situação emocional da participante; 5) A rede social e pessoal da participante (perguntas para a construção do Mapa de Redes); 6) A rede familiar da participante (perguntas para a construção do Genograma) e 7) Desfecho da entrevista.

\subsubsection{Mapa de Redes}

Trata-se de um instrumento elaborado por Sluzki (1997), que consiste em representar a rede social do indivíduo a partir de um mapa dividido em quatro quadrantes, relacionados à família, às amizades, às relações de trabalho ou estudo, às relações comunitárias e às relações com instituições (como serviço de saúde e jurídico) ou de credo religioso. A forma como o Mapa de Redes é configurado pode ser visualizada na Figura 1, oriunda de Santos (2009). 


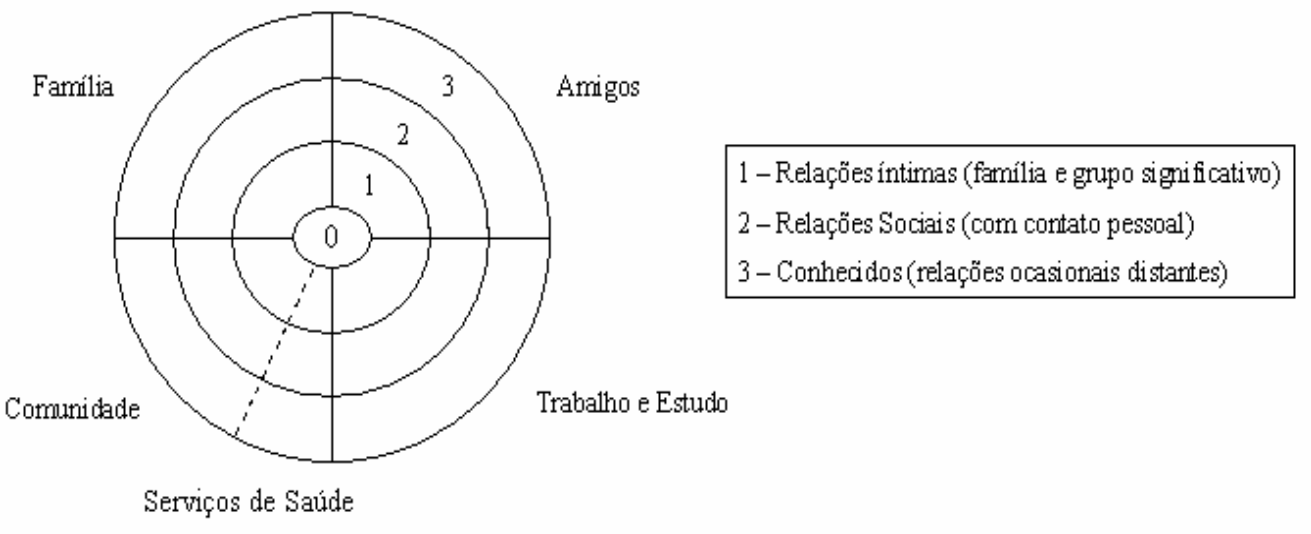

Figura 1. Mapa de Redes proposto por Sluzki (1997)

Para fins do presente estudo, a representação gráfica da participante foi colocada no centro do círculo e, no lugar dos Serviços de Saúde, conforme modelo sugerido por Sluzki (1997), foi inserido o GRATA.

Como já exposto anteriormente, as questões utilizadas na montagem do Mapa de Redes foram incorporadas ao roteiro de entrevista, no item 5. Assim, a construção dos mapas foi realizada conjuntamente pela pesquisadora e pelas participantes. Foram anotados todos os nomes mencionados pelas participantes e identificados o tipo de relação que a participante possuía com aquelas pessoas, de modo a facilitar a escolha da localização em que elas deveriam ser inseridas nos mapas. Dessa forma, foi possível verificar graficamente o grau de proximidade e o tipo de vínculo que a participante tinha com cada uma das pessoas mencionadas por ela, com quem ela podia contar, quem ela vê regularmente e de quem ela estava afastada naquele momento de sua vida (Sluzki, 1997). Para fins de apresentação, todos os nomes próprios foram substituídos por pseudônimos.

Seguindo as recomendações de Santos (2009), todos os nomes das pessoas citadas pelas participantes foram modificados pelo tipo de relação que mantinham com a mesma (mãe, pai, amigo, vizinho, colega, entre outros), sendo que o gênero de cada um foi representado pelo símbolo do sexo masculino em verde ( $\left(\boldsymbol{F}^{\prime}\right)$ e do sexo feminino em rosa ( $(+)$.

\subsubsection{Genograma}

O padrão de relação e os mitos existentes dentro de uma família são ensinamentos seguidos pela maior parte de seus membros. Muitas vezes, no entanto, tenta-se corrigir o 
que se acredita que não deu certo, assim como se procura repetir o que desde tempos imemoriais foi bem-sucedido e transmitido de uma geração a outra. Desse modo, cria-se certa dinâmica ou um tipo movimento ao estar no mundo, que é específico de cada família e que, por meio da construção do Genograma, é possível objetivar. Assim, ele pode ser caracterizado como uma estrutura de gráficos padronizada, utilizada universalmente pela genética, para representar a estrutura interna de uma família (Wright \& Leahy, 2002). Tem por objetivo levantar informações sobre os membros e as relações familiares através das gerações e se constitui em uma ferramenta de avaliação utilizada também pela terapia sistêmica de família (Krüger \& Werlang, 2008).

Atualmente, o Genograma tem sido amplamente empregado como instrumento de coleta de dados, especialmente para pesquisas científicas de natureza qualitativa sobre as relações familiares (Gerson \& McGoldrick, 1993; Wendt \& Crepaldi, 2008). Como instrumento, o Genograma permite a detecção dos relacionamentos existentes na família e, a partir da caracterização da estrutura familiar e de sua posição no ciclo de vida, também permite que o pesquisador desenvolva hipóteses a respeito dos padrões de vínculos e tipos de fronteiras estabelecidas naquele contexto (McGoldrick, Gerson, \& Petry, 2008). Além disso, o instrumento também permite a verificação de possíveis triangulações dentro da família.

Segundo Symanski (2004), o Genograma pode ser utilizado como um instrumento de coleta de dados que, somado a outros, como a entrevista, permite uma ampla caracterização da vida familiar. Além disso, segundo McGoldrick, Gerson e Petry (2008), o Genograma possivelmente representa, atualmente, o instrumento mais bem elaborado para avaliar as conexões entre família e doença.

Wendt e Crepaldi (2008) sugerem a existência de "padrões de relacionamento cristalizados dentro do sistema familiar" (p. 305). Trata-se de formas recorrentes de relacionamento entre os membros da família, que dão origem ao que as mencionadas autoras nomearam como padrões transacionais. Tais padrões foram definidos como: relacionamento harmônico, relacionamento muito estreito ou superenvolvimento, relacionamento fundido e conflitual, aliança, relacionamento conflituoso, relacionamento vulnerável, relacionamento distante, rompimento, triangulação e coalizão. As definições de cada um dos padrões transacionais serão expostas a seguir, de acordo com a classificação proposta por Wendt e Crepaldi (2008). 
Relacionamento harmônico: pode ser definido como a experiência emocional de união entre os membros da família que alimentam sentimentos positivos entre si. Há reciprocidade de interesses, atitudes e valores, assim como diferenciação dos membros entre si, e desses membros como suas respectivas famílias de origem.

Relacionamento muito estreito ou superenvolvimento: trata-se dos relacionamentos onde predominam a fusão e a dependência emocional entre os familiares, caracterizando a indiferenciação dos membros.

Relacionamento fundido e conflitual: existência de estreita dependência emocional e conflitos frequentes entre os membros da família, sem diferenciação.

Aliança: remete a ligações baseadas em lealdades invisíveis que, apesar de suscitarem interações positivas, podem interferir no processo de diferenciação dos membros, mas em menor grau do que o superenvolvimento.

Relacionamento conflituoso: relações que envolvem atritos constantes e desavenças no meio familiar, caracterizados por dificuldades de comunicação, tais como desqualificações e desconfirmações do outro. Esses padrões disfuncionais de comunicação podem evoluir para padrões simétricos, capazes de gerar violência física.

Relacionamento vulnerável: não há conflito explícito, mas existe a possibilidade da ocorrência de conflitos em condições adversas ou fases de transição.

Relacionamento distante: forma de relacionamento geralmente encontrada nas famílias desligadas, com fronteiras rígidas. Há pouco contato entre os membros, principalmente de ordem emocional.

Rompimento: não há contato entre os membros da família, apesar de ainda haver ligação emocional entre os mesmos.

Triangulação: trata-se da configuração emocional de três membros da família, onde o indivíduo "triangulado" possui a função de regular a tensão existente os outros dois membros e, quando não há conflito explícito, esse indivíduo vivencia sentimentos de insegurança ou sofrimento emocional. No caso de conflito, o embaraço ou o sofrimento passa a ser transferido para os membros da díade, despertando sentimento de alívio no terceiro.

Coalizão: propriedade característica das tríades, é definida pela união de quando dois membros da família contra um terceiro. 
Vale ressaltar que os padrões transacionais, apesar de serem recorrentes, podem ser modificados ao longo do tempo, principalmente durante as fases de transição que a família vivencia. Tais mudanças configuram importantes meios pelos quais os membros da família podem se diferenciar e, dessa forma, dar continuidade à família (Wendt \& Crepaldi, 2008).

As legendas do Genograma, desenvolvidas por McGoldrick e Gerson (1995) e adaptadas por Wendt e Crepaldi (2008), encontram-se no Anexo 1. As questões a serem utilizadas para montagem do instrumento, por sua vez, encontram-se no item 6 do roteiro de entrevista.

\subsubsection{Critério de Classificação Econômica Brasil/2010 (CCEB/10)}

No Brasil, desde 1970, têm sido utilizados critérios padronizados de classificação socioeconômica, o que torna o país pioneiro no uso de critérios padronizados para esse fim (Ambrósio, 2010). No entanto, a implantação desses critérios seguiu uma história bastante complexa. O Critério Brasil foi criado em 1997, a partir da junção de dois outros critérios: ABA-ANEP e Critério ABIPEME, e já passou por três revisões: em 2005, em 2006/07 e em 2008. O formato do instrumento utilizado no presente estudo é fruto desta última revisão, que entrou em vigor no ano de 2010 e unificou a classificação dos consumidores em categorias econômicas, e não mais socioeconômicas (Associação Brasileira de Empresas de Pesquisas [ABEP], 2010). O Critério de Classificação Econômica Brasil 2010 encontra-se no Anexo 2.

De acordo com dados da ABEP (2010), os objetivos do Critério Brasil são: 1. Oferecer um sistema de pontuação padronizado e eficiente, estimativo da capacidade de consumo; 2 . Discriminar os grupos de acordo com a capacidade de consumo de produtos e serviços a que têm acesso; 3. Classificar os domicílios, a partir da concepção de que classe é uma característica familiar; 4. Utilizar informações objetivas e sucintas de fácil coleta e utilização e 5. Possibilitar uma uniformidade geográfica e estabilidade ao longo do tempo.

Por isso, o CCEB/10 é composto por oito indicadores discriminantes da renda: televisão em cores, número de rádios, banheiros, automóveis, empregada mensalista, máquina de lavar roupa, videocassete ou DVD, freezer (podendo ser aparelho independente ou parte da geladeira duplex) e nível educacional do chefe de família. A posse de tais itens é pontuada conforme as tabelas que se encontram no Anexo 2. 
De acordo com a pontuação de corte das classes, o indivíduo é classificado, respectivamente, nos estratos correspondentes aos pontos obtidos. Enfatiza-se que o CCEB/10 deixa de realizar a classificação da população em termos de "classes sociais" e passa a separar o mercado a partir de classes econômicas, em função da estimativa do poder de compra das pessoas e das famílias urbanas, conforme a renda familiar auferida. A Tabela 3 indica a divisão em classes, a partir da pontuação obtida no CCEB/10, e as respectivas rendas familiares.

Tabela 3. Distribuição da pontuação no CEEB/10 e renda média familiar no ano de 2008, em função da classe econômica

\begin{tabular}{ccc}
\hline Classe & Pontos & Renda média familiar (Valor Bruto em R\$) \\
\cline { 3 - 3 } & & $\mathbf{2 0 0 8}$ \\
\hline A1 & 42 a 46 & 14.366 \\
A2 & 35 a 41 & 8.099 \\
B1 & 29 a 34 & 4.558 \\
B2 & 23 a 28 & 2.327 \\
C1 & 18 a 22 & 1.391 \\
C2 & 14 a 17 & 933 \\
D & 8 a 13 & 618 \\
E & 0 a 7 & 403
\end{tabular}

Fonte: ABEP (2010)

\subsection{Procedimento}

O estudo foi aprovado pelo Comitê de Ética em Pesquisa do Hospital das Clínicas da Faculdade de Medicina de Ribeirão Preto da Universidade de São Paulo (HC-FMRP-USP), processo HCRP no 2155/2010. A aprovação do Comitê de Ética encontra-se no Anexo 3.

\subsubsection{Coleta de dados}

O procedimento de coleta de dados foi empreendido no período de abril a dezembro de 2010. As participantes foram selecionadas e recrutadas de acordo com os critérios de inclusão e exclusão previamente estabelecidos. Uma vez cumpridos esses critérios de elegibilidade, as pacientes foram abordadas na data do retorno ambulatorial e convidadas a 
participarem da pesquisa. Foi então agendado um horário de acordo com a disponibilidade de cada participante. Após explicar detalhadamente a natureza e os objetivos do estudo, foi solicitado que elas assinassem o Termo de Consentimento Livre e Esclarecido (Apêndice 2) para participação na pesquisa, onde constavam por escrito os objetivos, o método, a responsabilidade ética da pesquisadora com os dados obtidos e a possibilidade de desistência da entrevistada a qualquer momento do processo de coleta de dados.

A aplicação das entrevistas com cada participante foi realizada individualmente, em situação face a face, em sala reservada da instituição hospitalar, com condições adequadas de conforto e privacidade. As entrevistas tiveram duração aproximada de 60 minutos e foram audiogravadas mediante anuência das participantes, assegurando maior fidedignididade dos dados colhidos e objetividade do estudo. Nas gravações ficaram registradas a linguagem falada, com a entonação e intensidade das verbalizações, o que auxiliou a análise dos dados.

Juntamente com as entrevistas, foram construídos os Genogramas e os Mapas de Redes. Foi explicitado para as participantes a importância da utilização dos mesmos para a caracterização de sua rede familiar e da rede de apoio social que a sustenta. Foi pedido que as participantes fornecessem nomes, idades, possíveis doenças e falecimentos de pessoas significativas e dos membros de sua família, citados por ela durante a entrevista, e outros dados que ela julgar relevantes para a compreensão do apoio social recebido. Além disso, também foi requisitado que as participantes informassem pessoas ou instituições e serviços que elas consideram parte de sua rede de relações. Por fim, foi pedido que elas apontassem o tipo de relação existente entre elas e as pessoas que compõem suas redes sociais significativas, principalmente no que diz respeito às relações familiares, tendo sido estabelecido anteriormente que relacionamento vulnerável seria uma relação frágil, instável e relacionamento conflituoso seria aquele permeado por brigas e discussões.

Vale ressaltar que todos os nomes mencionados pelas participantes foram indicados pelas suas iniciais, preservando assim o sigilo e a identidade das pessoas em questão. Quanto aos nomes das próprias participantes, a pesquisadora perguntava ao final das entrevistas qual o nome que as participantes gostariam que fosse utilizado para se referir a elas na pesquisa. Assim, foram utilizadas as sugestões que as próprias participantes forneceram. Ao finalizar as entrevistas, a pesquisadora agradeceu a disponibilidade das 
participantes e perguntou se elas gostariam de receber o Mapa de Redes e o Genograma produzidos durante a entrevista.

\subsubsection{Análise dos dados}

As entrevistas audiogravadas foram transcritas na íntegra e literalmente, respeitando a sequência e a forma como foram expressas as falas. O material coligido constituiu o corpus da pesquisa, que possibilitou o trabalho de análise e interpretação. Esse material foi submetido à Análise de Conteúdo na modalidade temática (Bogdan \& Biklen, 1994), que visa ultrapassar os conteúdos manifestos até atingir os conteúdos latentes. Os dados foram organizados em categorias, subcategorias e elementos de análise, levando-se em conta a regularidade das respostas e os padrões convergentes de conteúdo dos relatos. Para tanto, foram seguidos os passos metodológicos recomendados pela literatura (Triviños, 1987):

1- Pré-análise (leituras exaustivas, organização do material e sistematização de ideias e eixos estruturantes);

2- Descrição analítica (categorização de dados em unidades de registro, a partir da similaridade dos conteúdos);

3- Interpretação referencial (tratamento de dados e interpretações dos significados dos conteúdos temáticos com base no referencial teórico assumido pela pesquisadora).

Concomitantemente à elaboração das categorias temáticas, os Genogramas e Mapas de Redes, construídos à mão pela pesquisadora durante a coleta dos dados, conjuntamente com as participantes do estudo, foram melhor diagramados com uso de um programa específico para criação de elementos gráficos, denominado CorelDRAW Graphics Suite, para facilitar a visualização dos mesmos.

Na última etapa da análise dos dados foi realizada a análise interpretativa do material, concomitantemente pela pesquisadora e pelo orientador da pesquisa. Os pontos em concordância e que estavam relacionados com os objetivos do estudo foram considerados para a discussão, permitindo descrever em detalhes os sentidos recorrentes que surgiram, buscando com esse enfoque colocar em relevo a densidade e riqueza do material coligido. Esse tipo de análise se assenta nas associações dos entrevistados diante das questões propostas. Consiste essencialmente em colocar em evidência a significação das palavras, ações e produções imaginárias de cada participante, que emergiram no material ideativo produzido na relação estabelecida com a entrevistadora. 
A análise das redes sociais e do apoio social partiu da convergência entre os relatos das participantes nas entrevistas e os dados retirados dos Mapas de Redes, e englobou: os aspectos estruturais, ou seja, tamanho, composição, densidade, grau de dispersão e homogeneidade/heterogeneidade das redes; os atributos do vínculo, que incluíam a história da relação, a intensidade do compromisso, a freqüência de contatos, a reciprocidade, a função predominante e a multidimensionalidade do vínculo; e, por fim, os tipos de funções de ajuda, que configuram o apoio emocional, o acesso a novos contatos, guia cognitivo ou de conselhos, regulação social, a ajuda material e financeira e os serviços e cuidados. Também foram analisadas: vida social das participantes e a vivência nas redes sociais de amigos. Os dados extraídos dos Genogramas, por sua vez, ilustraram a configuração das famílias e os padrões transacionais presentes em cada uma. Foram analisados: os relacionamentos vulneráveis, harmônicos, distantes, conflituosos, fundidos e conflituosos, muito estreitos e as alianças. 


\section{RESULTADOS}

Os resultados do presente estudo serão apresentados em duas partes. Primeiramente, será realizada a caracterização das participantes: serão esquematicamente expostos os dados socioeconômicos de todas as participantes e, em seguida, será realizada uma análise vertical (de cada uma). Em uma segunda parte da exposição dos resultados, serão apresentadas, esquematicamente, as categorias, subcategorias e os elementos de análise. Esses resultados também serão divididos e enquadrados em dois eixos, que dizem respeito aos objetivos desta pesquisa e que serão melhor descritos posteriormente. Esse modelo de análise tomou como base o modelo utilizado por Orlandi (2011).

\subsection{Caracterização das Participantes}

Visando a uma abordagem mais completa e didática da individualidade das participantes, optou-se por dividir a caracterização das mesmas em duas partes. Como exposto anteriormente, a primeira parte irá contemplar os aspectos socioeconômicos e, em um segundo momento, será apresentada uma descrição vertical de cada participante, contemplando sua trajetória de vida e aspectos do TA, bem como suas vivências nas redes sociais significativas e o apoio social percebido.

\subsubsection{Caracterização socioeconômica}

A Tabela 9, a seguir, apresenta a caracterização socioeconômica das participantes. Seguindo o modelo proposto por Orlandi (2011), procurou-se delinear o perfil de cada uma, incluindo os seguintes aspectos: idade, escolaridade, estado marital/relacionamento amoroso, religião/espiritualidade, ocupação profissional, renda familiar, número de pessoas que moram na casa e classificação econômica (segundo a pontuação no CCEB/2010).

Vale ressaltar que há particularidades em alguns casos, tais como: participantes que são sustentadas financeiramente pelos pais, mas moram em casas separadas; participantes que têm uma ocupação, mas que não podem exercê-la no momento, em função de comprometimento físico resultante do TA; participantes que moram com os pais, mas têm uma renda própria, entre outros. Apesar da Tabela 4 oferecer um panorama geral dos aspectos socioeconômicos das participantes, as particularidades de cada caso serão apontadas na análise vertical de cada uma delas. 
Tabela 4. Caracterização sociodemográfica das participantes do estudo

\begin{tabular}{|c|c|c|c|c|c|c|c|c|c|}
\hline Participantes & $\begin{array}{l}\text { Idade } \\
\text { (anos) }\end{array}$ & $\begin{array}{c}\text { Nível de } \\
\text { escolaridade }\end{array}$ & Profissão / Ocupação & $\begin{array}{c}\text { Estado marital / Relação } \\
\text { amorosa }\end{array}$ & Filhos & $\begin{array}{c}\text { Número de } \\
\text { pessoas que } \\
\text { moram na casa }\end{array}$ & Renda familiar total & $\begin{array}{l}\text { Classificação } \\
\text { no CCEB }\end{array}$ & Religião / Espiritualidade \\
\hline Bárbara & 24 & $\begin{array}{l}\text { Ensino Superior } \\
\text { incompleto }\end{array}$ & $\begin{array}{l}\text { Estudante } \\
\text { universitária }\end{array}$ & $\begin{array}{l}\text { Solteira, namorando } \\
\text { atualmente }\end{array}$ & Não & Cinco & 5,5 salários mínimos & B2 & Católica, não praticante \\
\hline Sofia & 27 & $\begin{array}{l}\text { Ensino Médio } \\
\text { completo }\end{array}$ & $\begin{array}{c}\text { Atendente de } \\
\text { telemarketing- } \\
\text { afastada por motivos } \\
\text { de saúde }\end{array}$ & $\begin{array}{l}\text { Solteira, sem } \\
\text { relacionamento amoroso }\end{array}$ & Não & Quatro & 2,5 salários mínimos & $\mathrm{C} 1$ & $\begin{array}{l}\text { Sem religião, mas com } \\
\text { espiritualidade }\end{array}$ \\
\hline Carolina & 31 & $\begin{array}{l}\text { Ensino } \\
\text { Fundamental } \\
\text { completo }\end{array}$ & Dama de companhia & $\begin{array}{l}\text { Separada, sem } \\
\text { relacionamento amoroso }\end{array}$ & $\begin{array}{l}\text { Sim (dois, } 10 \\
\text { e } 13 \text { anos) }\end{array}$ & Três & 1,5 salário mínimo & $\mathrm{C} 2$ & $\begin{array}{l}\text { Evangélica, não } \\
\text { praticante }\end{array}$ \\
\hline Sissi & 27 & $\begin{array}{l}\text { Ensino Superior } \\
\text { incompleto }\end{array}$ & $\begin{array}{c}\text { Funcionária pública e } \\
\text { estudante } \\
\text { universitária }\end{array}$ & $\begin{array}{l}\text { Solteira, sem } \\
\text { relacionamento amoroso }\end{array}$ & Não & Mora sozinha & 2 salários mínimos & $\mathrm{C} 1$ & Evangélica, praticante \\
\hline Maria & 31 & $\begin{array}{l}\text { Ensino Superior } \\
\text { completo }\end{array}$ & $\begin{array}{l}\text { Advogada e auxiliar } \\
\text { administrativa }\end{array}$ & $\begin{array}{l}\text { Separada, sem } \\
\text { relacionamento amoroso }\end{array}$ & Não & Quatro & 2 salários mínimos & B1 & Presbiteriana, praticante \\
\hline Fernanda & 40 & $\begin{array}{l}\text { Ensino Médio } \\
\text { completo }\end{array}$ & $\begin{array}{l}\text { Auxiliar de } \\
\text { enfermagem }\end{array}$ & $\begin{array}{l}\text { Solteira, sem } \\
\text { relacionamento amoroso }\end{array}$ & Não & Três & 3,5 salários mínimos & $\mathrm{C} 1$ & $\begin{array}{c}\text { Católica, não praticante, } \\
\text { mas acredita no } \\
\text { espiritismo }\end{array}$ \\
\hline Grazieli & 19 & $\begin{array}{l}\text { Ensino Médio } \\
\text { completo }\end{array}$ & $\begin{array}{l}\text { Vendedora em banca } \\
\text { de revistas }\end{array}$ & $\begin{array}{l}\text { Solteira, namorando } \\
\text { atualmente }\end{array}$ & Não & Quatro & 1,5 salário mínimo & $\mathrm{C} 2$ & Evangélica, praticante \\
\hline Amanda & 22 & $\begin{array}{l}\text { Ensino Médio } \\
\text { completo }\end{array}$ & Secretária & $\begin{array}{l}\text { Solteira, sem } \\
\text { relacionamento amoroso }\end{array}$ & Não & Quatro & 7 salários mínimos & B2 & Sem religião \\
\hline Juliana & 30 & $\begin{array}{l}\text { Ensino Superior } \\
\text { completo }\end{array}$ & Advogada & $\begin{array}{l}\text { Solteira, namorando } \\
\text { atualmente }\end{array}$ & Não & Três & 3 salários mínimos & B1 & Espírita, praticante \\
\hline Marina & 29 & $\begin{array}{l}\text { Ensino Médio } \\
\text { completo }\end{array}$ & $\begin{array}{l}\text { Auxiliar em instituição } \\
\text { e dama de companhia }\end{array}$ & Separada & $\begin{array}{l}\text { Sim (dois, } 11 \\
\text { e } 3 \text { anos) }\end{array}$ & Três & 3 salários mínimos & B2 & Evangélica, praticante \\
\hline Estrelinha & 28 & $\begin{array}{l}\text { Ensino Médio } \\
\text { completo }\end{array}$ & Promotora de vendas & $\begin{array}{l}\text { Solteira, namorando } \\
\text { atualmente }\end{array}$ & Não & Três & 4 salários mínimos & B2 & Sem religião \\
\hline Ana & 24 & $\begin{array}{l}\text { Ensino Superior } \\
\text { incompleto }\end{array}$ & $\begin{array}{l}\text { Estudante } \\
\text { universitária }\end{array}$ & $\begin{array}{l}\text { Solteira, sem } \\
\text { relacionamento amoroso }\end{array}$ & Não & Cinco & 7 salários mínimos & B1 & Católica, praticante \\
\hline
\end{tabular}


No que concerne à faixa etária, nota-se que a idade das participantes variou entre 19 e 40 anos, sendo que a idade média corresponde a 27,7 anos. Oito participantes tinham idades entre 24 e 30 anos (Bárbara, Sissi, Amanda, Ana, Juliana, Marina, Estrelinha e Sofia), duas tinham 31 anos (Maria e Carolina), uma tinha 40 anos (Fernanda) e uma, 19 anos (Grazieli).

Em relação ao estado marital, seis participantes eram solteiras (Sissi, Sofia, Juliana, estrelinha, Ana e Fernanda). Três eram separadas (Carolina, Marina e Maria). Maria foi casada na adolescência, aos 16 anos de idade; o casamento durou três anos. Carolina, por sua vez, foi casada duas vezes: o primeiro casamento durou dois anos e o casal teve um filho, enquanto que o segundo durou 12 anos e o casal também teve um filho. Na época da entrevista, Marina havia se separado do marido a um ano, com quem teve dois filhos: uma menina de 11 anos e um menino de três. Bárbara e Grazieli namoravam e relataram estarem muito felizes com os respectivos namorados. Juliana e Estrelinha também namoravam, mas relataram possuir um relacionamento conturbado com seus respectivos namorados.

Três participantes (Bárbara, Fernanda e Ana) eram católicas, sendo que apenas a última era praticante. Fernanda considerava-se católica, mas relatou também acreditar no espiritismo. Quatro participantes seguiam a religião evangélica (Carolina, Sissi, Marina e Grazieli), sendo que apenas Carolina considerava-se não praticante. Sissi frequentava a igreja duas vezes por semana; referiu que a igreja é um lugar onde ela pode se fortalecer e se encher de esperança. Grazieli não apontou a igreja como fonte de apoio explicitamente, mas esta aparecia em seu discurso inúmeras vezes, tanto como local onde fazia amigos quanto como um lugar que ela visitava frequentemente e que, quando não podia frequentar, sentia-se mal. Três participantes (Sofia, Amanda e Estrelinha) relataram não ter religião. Sofia relatou ter apenas espiritualidade, ou seja, acredita em Deus, mas não segue uma doutrina específica.

Em relação ao grau de escolaridade, seis participantes apresentaram ensino médio completo (Sofia, Fernanda, Amanda, Marina, Estrelinha e Grazieli) e apenas uma tinha ensino fundamental completo (Carolina). Três participantes apresentaram ensino superior incompleto (Sissi, Ana e Bárbara), uma vez que estavam cursando o último ano de graduação. Apenas duas participantes apresentaram ensino superior completo (Maria e Marina), e ambas eram graduadas em Direito. Quanto à inserção profissional, nove participantes estavam empregadas. Três não trabalhavam: Bárbara e Ana apenas estudavam, e Sofia havia sido afastada de seu trabalho como atendente de telemarketing, em razão de um comprometimento físico decorrente do TA. 
No que tange à renda familiar, três participantes relataram não ter conhecimento da quantia exata (Sofia, Ana e Grazieli), fornecendo apenas uma quantia aproximada. As três moravam com os pais, em casas próprias, e eram sustentadas por eles. Sete participantes (Sofia, Carolina, Sissi, Maria, Grazieli, Juliana e Marina) possuíam rendas entre 1 e 3 salários mínimos, e cinco (Estrelinha, Amanda, Fernanda, Bárbara e Ana) possuíam renda familiar entre 3,5 e 7 salários mínimos. Não foram identificadas situações de desemprego.

Segundo as pontuações do CCEB, três participantes (Fernanda, Sissi e Sofia) receberam a classificação $\mathrm{C} 1$, ou seja, possuíam renda familiar de aproximadamente $\mathrm{R} \$ 1.391,00$. Duas participantes (Grazieli e Carolina) foram inseridas na classificação C2 do CCEB, indicando renda familiar de aproximadamente $\mathrm{R} \$ 933,00$. Bárbara, Amanda, Marina e Estrelinha apresentaram classificação B2, ou seja, de acordo com o CCEB, essas participantes possuem renda familiar de aproximadamente $\mathrm{R} \$ 2.327,00$. Por fim, três participantes (Maria, Juliana e Ana) receberam a classificação B1 no instrumento, indicando renda familiar aproximada de $\mathrm{R} \$ 4.558,00$.

Em suma, a renda das participantes variou entre, aproximadamente, $R \$ 933,00$ (Carolina e Grazieli) e R\$4.558,00 (Maria, Juliana e Ana). Embora não tenham sido constatadas situações de desemprego, a renda familiar da maioria das participantes era consideravelmente baixa, levando-se em conta o número de pessoas que se mantinham com esses proventos.

Acredita-se que a caracterização socioeconômica das participantes tenha sido um aspecto fundamental a ser considerado na análise dos dados, pois permitiu a percepção da medida em que as necessidades de suporte material estão sendo supridas com o montante de recursos financeiros disponíveis em cada unidade familiar.

\subsubsection{Contextualização da trajetória de vida das participantes: A singularidade das vivências do TA, da configuração das redes sociais significativas e da percepção do apoio social recebido}

Nesta parte da exposição dos resultados, procurou-se integrar os dados referentes à trajetória de vida das participantes, englobando os momentos anteriores à ocorrência do TA, os conteúdos referentes à instalação do transtorno, a vivência nas redes sociais e o apoio social. A integração desses dados será realizada de modo vertical, isto é, por meio de uma análise individual, buscando destacar as particularidades de cada participante (Orlandi, 2011). 


\section{Participante 1- Bárbara}

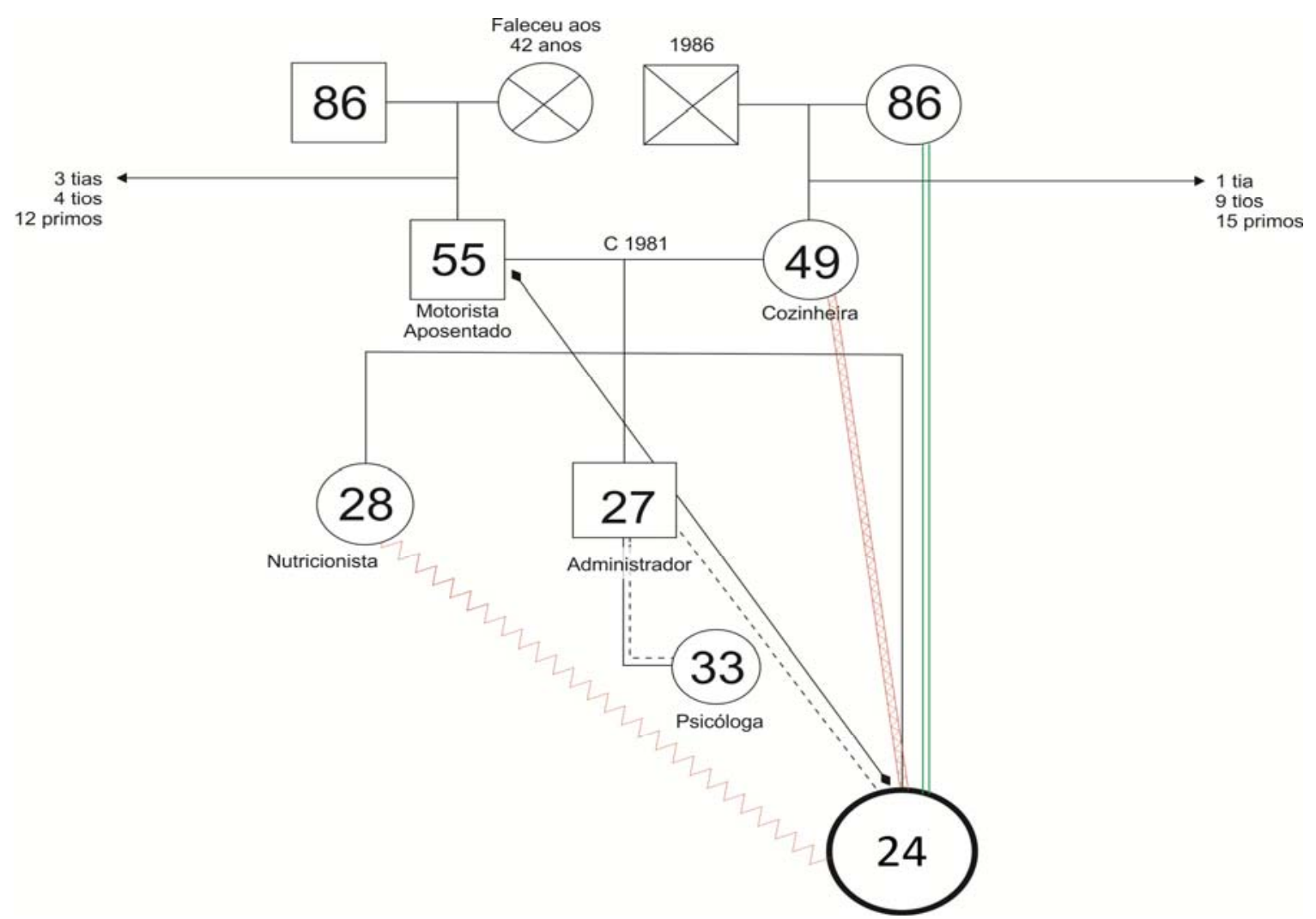

Figura 2. Genograma de Bárbara

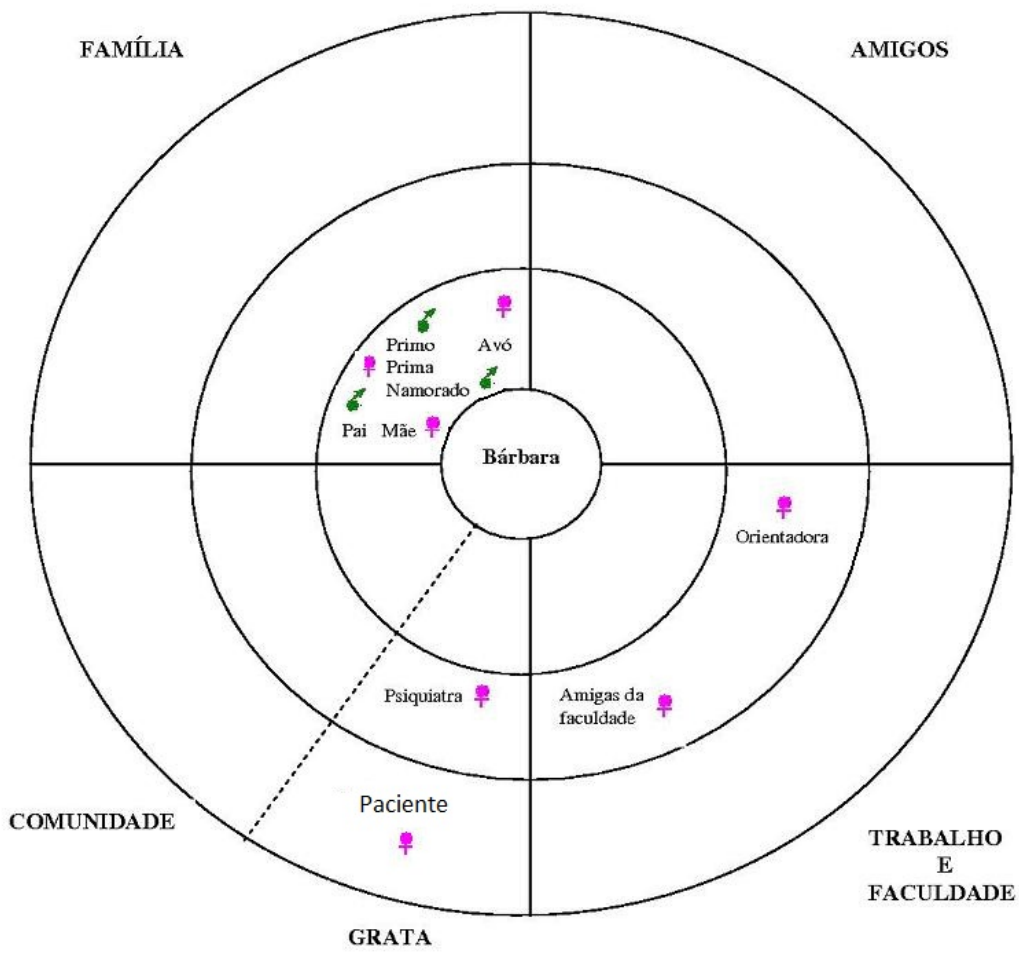

Figura 3. Mapa de Redes de Bárbara 
Quando foi entrevistada, Bárbara estava em tratamento no GRATA havia apenas um mês. Nesse momento de entrada no serviço, a participante pesava 53,7kg e tinha $1,63 \mathrm{~m}$ de altura, que resultavam em um IMC $=20,7 \mathrm{~kg} / \mathrm{m}^{2}$, considerado como dentro da faixa de normalidade. Ou seja, do ponto de vista da relação peso-altura, a paciente encontrava-se eutrófica no momento de sua participação na pesquisa. O diagnóstico, segundo os registros extraídos do prontuário médico da participante, era de AN do tipo purgativo, em comorbidade com transtorno de personalidade borderline e episódio depressivo moderado.

Antes da entrada no GRATA, Bárbara já havia se submetido a outros tratamentos para o TA. Relatou que há cerca de 10 anos havia iniciado o quadro de restrição alimentar, uso de laxantes, diuréticos e atividade física intensa. Em poucos meses o quadro se agravou, o que a levou a uma internação prolongada de sete meses, quando a participante pesava $29 \mathrm{~kg}$ e tinha $I M C=10,1 \mathrm{~kg} / \mathrm{m}^{2}$, que caracteriza quadro gravíssimo de desnutrição, ou seja, incompatível com a vida. Logrou uma melhora discreta, mas, posteriormente, sua condição clínica permaneceu instável, pois apresentava quadros recorrentes de pioras alternadas com melhoras. Essa instabilidade levou-a novamente a um estado de desnutrição muito grave e ela passou por mais três internações subsequentes, sendo uma delas em Hospital Dia, durante seis meses, intercaladas com outras internações mais curtas, de aproximadamente 15 dias. Relatou uma piora significativa dos sintomas no segundo semestre do ano de 2009, com uso mais frequente de laxantes, que correspondia a cerca de 10 comprimidos por dia, e indução de vômitos (até três vezes por semana).

$\mathrm{Na}$ época da entrevista, os dados antropométricos da participante não haviam sofrido mudanças significativas, em função do pouco tempo de tratamento que havia transcorrido desde a entrada no serviço até o momento da entrevista: seu peso era de $56,4 \mathrm{~kg}$ e IMC $=21,2 \mathrm{~kg} / \mathrm{m}^{2}$. As anotações psiquiátricas e nutricionais no prontuário indicavam que Bárbara referia sentir-se muito cansada, pois se mantinha quase todo o tempo mergulhada no ciclo "comer, tomar laxante, vomitar". Embora houvesse reduzido o consumo diário de laxantes para seis comprimidos, não era sempre que conseguia manter tal redução. Queixava-se frequentemente de fraqueza e tontura. Os vômitos aconteciam três vezes por semana, principalmente nos fins de semana, quando comia algo diferente. Não gostava da imagem que via refletida no espelho e sentia medo dos pais, pois eles não sabiam como lidar com o seu problema. 
Bárbara referiu que vive sob pressão devido à ambivalência entre o desejo de emagrecer e as cobranças acentuadas que recebe dos pais, que a ameaçam para que ela não volte a emagrecer, e da faculdade, onde os professores percebem que ela não está bem e cobram que ela se cuide. Além disso, a ambivalência também está relacionada com a ausência de redes sociais de amigos. Bárbara relatou que não é aceita nessas redes por não gostar de sair para comer, que é uma atividade que os colegas da faculdade compartilham com frequência.

Aí nisso, você entra naquele ciclo vicioso, porque "Ai, não como isso, não como aquilo", mas se você não come você também não tem amigos, você não é aceita porque as pessoas te excluem, de certa forma as pessoas te excluem em tudo... $E$ você também não quer ser colocada naquela posição: "Ai, eu sou diferente, eu sou doente, eu sou isso, eu sou aquilo..."

Por outro lado, Bárbara também relata um movimento de se excluir das redes sociais, já que, para interagir com os amigos, é preciso comer ou estar frente ao alimento, o que lhe desperta sentimentos disfóricos, como remorso e culpa. Além disso, o fato de não gostar de estar entre muitas pessoas impede que a participante tenha uma vida social minimamente satisfatória. Ela se sente observada pelas pessoas, o que aumenta seu desconforto. Acredita que as pessoas sempre ficam observando seus passos e, por isso, evita frequentar eventos sociais, tais como festas e bares. $\mathrm{O}$ uso abusivo de laxantes também foi considerado um vício e algo que a impedia de ter uma relação próxima com as amigas - por exemplo, de dormir na casa delas.

[...] Acho que, de certa forma, até eu, sabe, que acabava me colocando um pouco de lado também, mas aí com o tempo, sabe assim, é... Acho que o medo de você ser excluído é tão grande, sabe, que você começa a... meio que... Que, assim, se interar mais, ir junto, fazer as coisas também, só que assim... A sua culpa, seu sentimento de remorso, aquela coisa assim... É muito... Muito grande, sabe assim?

O desejo de ser incluída nas redes sociais de amigos foi um tema recorrente no discurso da participante durante a entrevista. Ela relatou fazer uso de algumas táticas para "se interar", tais como comer apenas frutas em casa para poder conseguir comer outras coisas (por exemplo, chocolate) junto aos amigos na faculdade. Essa estratégia de comer algo menos calórico em casa para depois se permitir comer alimentos calóricos com os 
amigos parecia funcionar como fator de redução da ansiedade e dos sentimentos negativos; ao mesmo tempo, servia para aproximá-la dos amigos. No entanto, a participante sente que algumas amigas se aproximam dela por interesse, pois ela costuma fazer com esmero todos os trabalhos da faculdade, e não a incluem em outras atividades sociais. Essa percepção faz com que Bárbara se sinta ainda mais excluída da sua rede de amigos e intensifica a ambivalência entre o desejo de integrar-se à rede e o desejo de isolar-se por completo.

Ah, sabe assim... Pô, é chato, sabe? Tá todo mundo junto, assim... Você quer ficar sozinha? Você não quer ficar sozinha, sabe... Daí... Às vezes, eu até dava umas indiretas, assim... Mas eu não tenho coragem de chegar e falar.

A interação com as pessoas da rede social significativa parecia exercer influência em várias dimensões do quadro de TA: Bárbara atribui o início do quadro psicopatológico à perda de pessoas próximas, às comparações com sua mãe e irmã (que, segundo ela, eram bastante magras), aos apelidos depreciativos que a irmã lhe atribuía, ao rígido controle alimentar exercido pela mãe e ao fato de o menino de que ela gostava na infância namorar uma menina magra. Segundo seu discurso, esses fatores resultavam em uma autoestima marcadamente rebaixada, sentimentos de inferioridade e um desejo de "provar aos outros que podia". A combinação desses elementos a teria levado à adotar restrição alimentar intensa.

Bárbara contou que namora havia dois anos e meio, e que mantinha um relacionamento saudável com o namorado. Considera-o como alguém paciente e com quem ela tem muitas afinidades e cumplicidade. Relatou que ele foi uma fonte de apoio bastante significativa em vários momentos difíceis que ela vivenciou, desde quando mudou-se de sua cidade de origem para cursar faculdade. Antes da ocorrência do TA, Bárbara considerava que tinha uma ampla rede social de amigos, uma vez que "dava mais abertura" para as pessoas de seu ambiente social e "era mais sociável". Atualmente, a participante "tem sempre um pé atrás" e "se fechou muito" para as pessoas. Esse afastamento das pessoas acabou por diminuir o tamanho e a composição de sua rede social significativa e por impedir a realização de atividades de lazer, até que o namorado passou a ser a única companhia social e fonte significativa de apoio para a participante. Juntos, frequentam alguns bares e passeiam no shopping.

A relação de Bárbara com os pais sempre foi bastante conflituosa, permeada por ameaças e cobranças. A participante caracterizou sua mãe como explosiva e seu pai como 
calmo, porém crítico. O relacionamento com o irmão é afetivamente distante, "como se ele não existisse ali", e a relação com a irmã é conflituosa, pois ela mesma é explosiva como a mãe. Bárbara referiu que os relacionamentos familiares, antes da ocorrência do TA, eram mais tranquilos, e que a origem dos conflitos estava relacionada com o fato dos familiares considerarem o TA como "uma frescura".

Notou-se uma ambivalência na questão referente ao apoio proveniente da rede familiar. Bárbara relatou que, apesar das cobranças, ameaças e brigas frequentes entre os membros da família, esta era a sua fonte de apoio mais significativa, juntamente com o namorado. No entanto, a participante mencionou que vivenciava muita insatisfação com o apoio recebido, pelo fato dele estar sempre acompanhado de muita exigência e crítica.

Apesar de tudo, assim, são... São meus amigos, sabe? São pessoas assim... Que eu digo, que são amigos mesmo, que são pessoas que eu posso contar em qualquer momento, que sempre me escutaram, sabe?

Não, eu tenho um apoio, sabe? Mas assim, eu acho que tem horas que é um apoio, assim... Não da forma que... Como eu gostaria, sabe? Porque... Imagina, você viver toda... Assim, sua vida sendo cobrada, ameaçada, sabe assim, então você fica com medo, você vive sempre com medo, assim... Nossa, sempre tendo que atender expectativas.

A rede social significativa de Bárbara era composta por, aproximadamente, nove membros, distribuídos entre os quadrantes da Família, do serviço de saúde (GRATA) e do Estudo. Ou seja, a rede social da participante apresenta tamanho médio e baixa composição e dispersão. Vale ressaltar que a participante inseriu a orientadora e as "amigas da faculdade" no quadrante de Estudo, sem atribuir uma quantidade específica para o número de amigas, o que dificultou a quantificação do número de membros da rede. Não foram inseridas pessoas no quadrante de Amigos nem da Comunidade. A maioria dos membros da rede $(n=6)$ concentrava-se no quadrante da Família, na parte de Relações Íntimas, sendo eles: mãe, pai, avó, um primo, uma prima e o namorado. A orientadora, as amigas da faculdade e a psiquiatra do GRATA foram consideradas Relações Sociais. Apenas uma paciente do GRATA, com quem Bárbara mantém contato, foi considerada Relação Distante. Os membros de cada quadrante têm conexões entre si, e a família também está conectada com a profissional do serviço de saúde. Assim, considera-se que a rede social de Bárbara apresenta baixa densidade. 


\section{Participante 2 - Carolina}

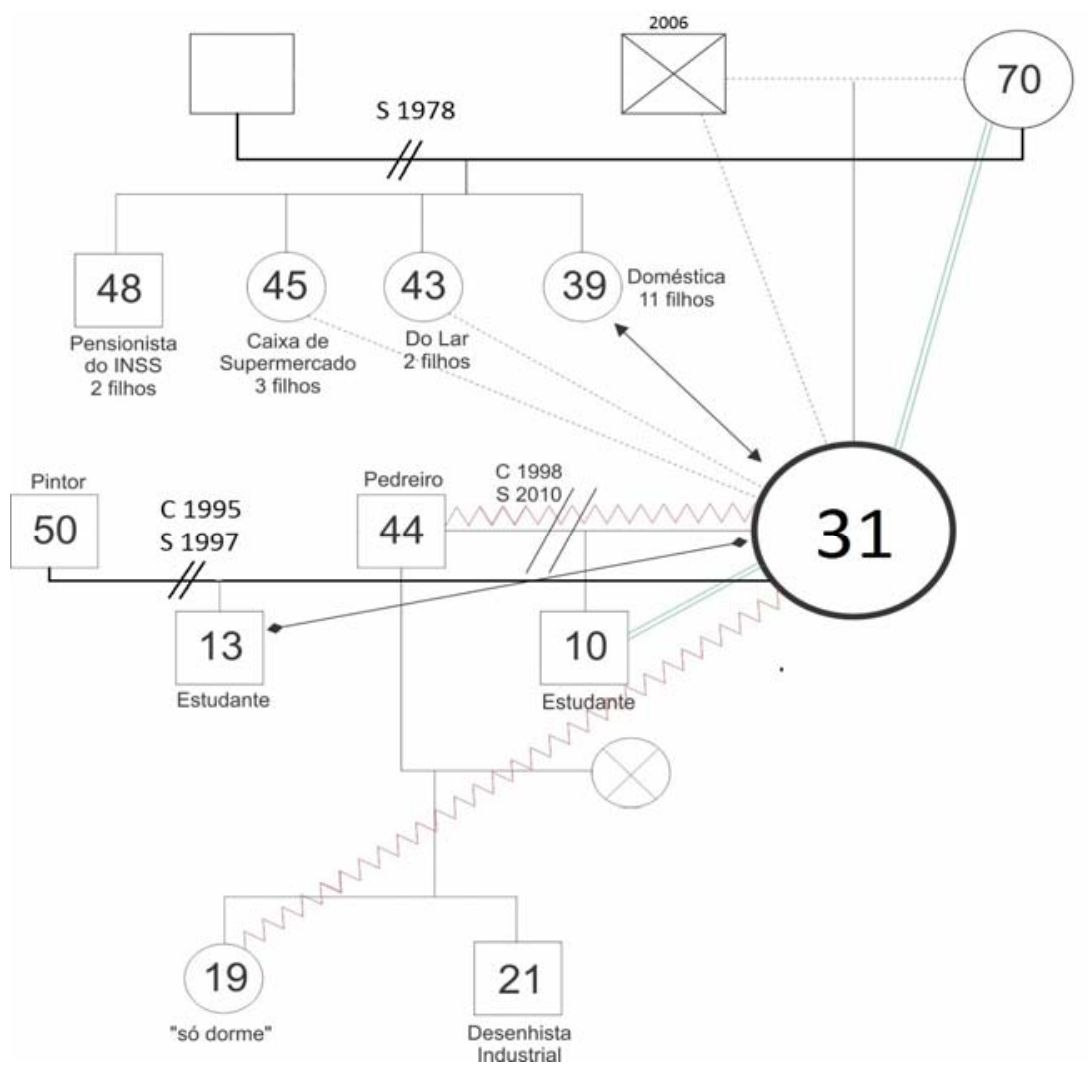

Figura 4. Genograma de Carolina

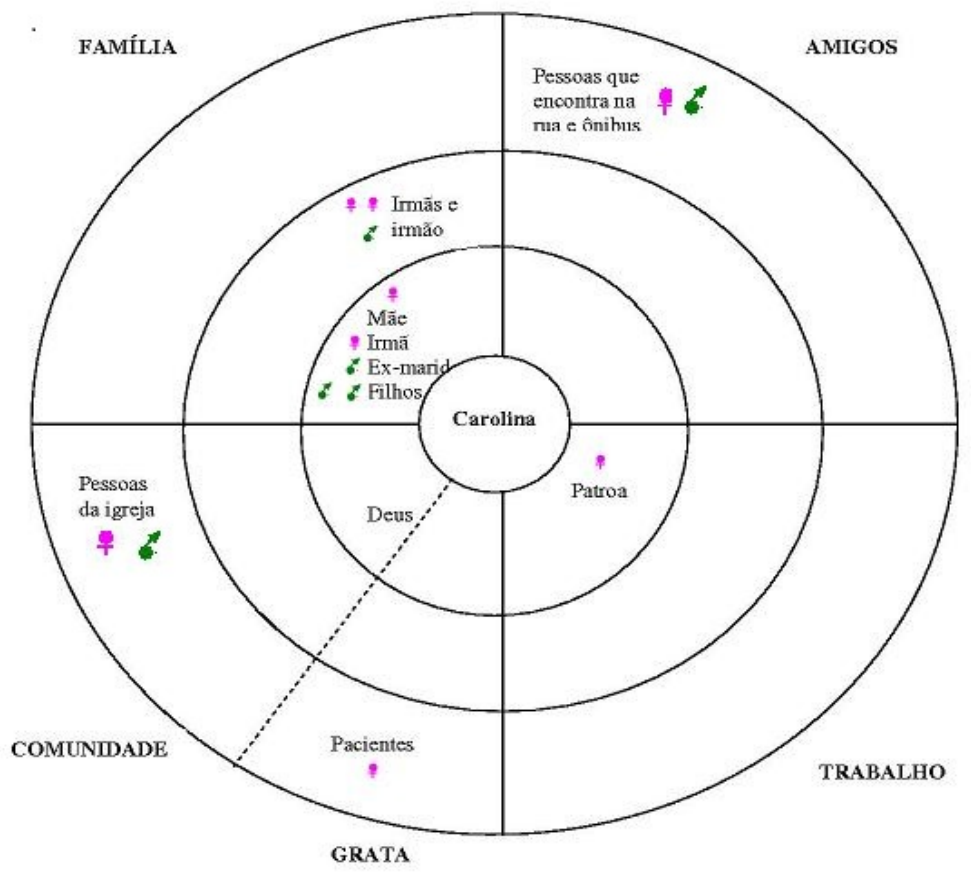

Figura 5. Mapa de Redes de Carolina 
Segundo consta no prontuário médico, antes de dar início ao tratamento no GRATA, Carolina havia procurado atendimento psiquiátrico no Hospital das Clínicas no ano de 2002, queixando-se de tristeza e desânimo. Relatou ideias de menos valia, chorava facilmente, apresentava anedonia, vontade de permanecer deitada o dia todo, descuido pessoal (por exemplo, não tomava banho), medo de ficar sozinha, irritabilidade e ideias suicidas. Contou sobre um episódio em que havia jogado álcool em si mesma, mas não chegou a colocar fogo pois sua mãe chegou na hora. Tinha sensação de ver vultos e ouvir vozes.

Após dois anos de tratamento na psiquiatria, Carolina foi encaminhada ao GRATA, em função da compulsão alimentar diária seguida da indução de vômitos, que ocorriam em média seis vezes ao dia. Tinha 24 anos de idade, pesava 98,4kg, tinha 1,65m de altura e IMC $=36,1 \mathrm{~kg} / \mathrm{m}^{2}$, considerado característico de obesidade. Na psiquiatria, a participante havia recebido o diagnóstico de $\mathrm{BN}$, em comorbidade com episódio depressivo moderado e transtorno de personalidade borderline.

Na época da entrevista, a participante estava em tratamento no GRATA havia sete anos. De acordo com os dados do prontuário, ela relatava estar se sentindo bem tranquila e menos irritada. Em contrapartida, sentia-se muito impulsiva para se alimentar, mas negava indução de vômitos e uso de laxantes. Carolina apresentava $101,3 \mathrm{~kg}$ e IMC = 37,2kg/ 2 .

Foi possível perceber que, no momento da entrevista, a participante estava passando por um período de mudanças em sua vida. Havia se separado recentemente do marido, com quem havia permanecido casada durante 12 anos e com quem teve um filho, que na época da entrevista tinha 10 anos de idade. A separação do casal não havia acontecido por meios legais de divórcio, mas o marido havia ido morar em outra casa. Notou-se que o fato de se tratar de uma segunda separação estava sendo muito difícil para Carolina: a participante havia sido casada anteriormente, há 13 anos. O casamento durou apenas um ano e sete meses, e o casal teve um filho, que atualmente tem 13 anos de idade. Carolina relata sentimentos de tristeza e solidão ao se dar conta que, novamente, se encontra sozinha, tendo que sustentar dois filhos.

Durante a entrevista, a participante relatou que vivencia constantemente um intenso sentimento de vazio, que parece estar relacionado com a sensação de solidão. Em contrapartida, Carolina também relata que não gosta de estar entre muitas pessoas e prefere ficar só. Segundo o discurso da participante, o sentimento de vazio costuma ser momentaneamente preenchido pela comida: ao se alimentar - ato este que costuma 
acontecer em quantidades bastante excessivas -, Carolina relata que se sente saciada e aconchegada. No entanto, a participante relata que é tomada por um sentimento de culpa logo após os episódios de compulsão alimentar. Assim, é possível notar que o discurso da participante é repleto de ambivalências.

Carolina relata que sempre comeu de forma excessiva, sempre vivenciou oscilações do humor e sempre foi "deprimida sorridente", denotando que escondia uma tristeza por trás de sorrisos falsos. Entretanto, quando questionada a respeito dos momentos em que percebe que os episódios de compulsão e purgação se tornam mais intensos, Carolina relata que percebeu um aumento na frequência desses episódios após a traição do ex-marido. A participante demonstrou-se bastante desconfortável em falar sobre esse fato, explicando apenas que aconteceu há dois anos e que ela tentou relevar, em função do filho. Há dois meses a participante resolveu "dar um basta".

Ah eu acho que eu sempre fui assim, sabe, assim de me alimentar muito, muito... De ser muito ansiosa, de me sentir muito mal sozinha, sabe... De me sentir deprimida sorridente, sabe aquela deprimida sorridente? De que você sorri pros outros, mas esconde? E... Só que quando aconteceu isso foi pior, né.

Em relação ao tratamento, Carolina relata que se sente mal por estar muito acima do peso esperado e, assim, "ser um espelho" para as outras pacientes do GRATA. Essa questão do "espelho" se trata de uma frase que uma paciente pronunciou durante um grupo de apoio, denotando que, em função da distorção de imagem corporal que possuía, costumava se enxergar gorda, e que considerava Carolina como um reflexo dessa imagem. Essa frase, dita por uma paciente do mesmo ambulatório no qual a participante faz tratamento, foi bastante marcante e fez com que Carolina se sentisse pior em relação ao próprio corpo.

No entanto, apesar da insatisfação com o peso a forma corporal, Carolina relata que não tem o desejo de ser magra como algumas das pacientes vinculadas ao GRATA. A participante considera o emagrecimento excessivo como uma forma de se tornar depende da ajuda de outras pessoas, de ser considerada "a coitada", e a ideia de se tornar alguém dependente lhe é bastante aversiva. O fato de ninguém da família da participante saber sobre o TA foi incluído no discurso como sendo uma forma de independência, de não querer parecer "a coitada" para as pessoas e de não querer dar trabalho para sua mãe. 
Carolina relata que sua mãe tem idade avançada (70 anos) e vários problemas de saúde, incluindo pressão alta. Considerando o medo de que a mãe a acompanhe no tratamento e acabe por passar mal, em função do longo período de espera para ser atendida no hospital, a participante tem medo de contar a ela sobre o TA. Para justificar suas idas ao hospital, Carolina conta aos seus familiares que está tratando o quadro de diabetes mellitus que possui. Entretanto, apesar da mãe "ser brava", não saber sobre a ocorrência do TA e de não fornecer apoio específico para a vivência do quadro, Carolina a considera como sua fonte mais significativa de apoio.

Outra pessoa que poderia acompanhar Carolina no ambulatório seria uma de suas irmãs, com quem a participante tem uma relação harmônica. No entanto, essa irmã tem 11 filhos que ocupam o seu tempo completamente. Procurando evitar dar mais trabalho e preocupação à irmã, Carolina prefere que ela não saiba do TA. Quanto aos outros irmãos, a participante não tem uma relação íntima a ponto de dividir as questões relacionadas ao quadro psicopatológico que apresenta, e menos ainda de pedir que eles a acompanhem no tratamento.

Vale ressaltar que o irmão e as três irmãs de Carolina são apenas por parte de mãe. O pai da participante nunca foi casado com sua mãe: os dois apenas tiveram uma relação caracterizada por poucos encontros casuais, em um dos quais a mãe de Carolina engravidou dela. Antes disso, a mãe da participante havia sido casada durante 12 anos, tendo tido quatro filhos, os já referidos irmãos de Carolina. A participante relata que não tem nada para falar a respeito do pai, exceto que o conheceu aos 15 anos de idade e que ele faleceu no ano de 2006.

Apesar de Carolina declarar de forma veemente que não tem o desejo de que seus familiares saibam do TA por medo de ser considerada "a coitada", no discurso da participante também aparece um sentimento muito intenso de culpa pela ocorrência do transtorno. Carolina se considera "culpada por estar doente", e sente "muita raiva de si mesma". Nesse sentido, o ato de esconder o TA dos familiares pode ser considerado como uma forma de autopunição pela culpa de ter desenvolvido o quadro.

Ninguém tem culpa de eu estar doente. Quem tem culpa é eu mesma, então eu sinto muita raiva de mim mesma.

Associado ao sentimento de culpa, também surge o sentimento de incapacidade. A participante relata que tem vontade de fazer algumas coisas, mas não consegue por falta de 
coragem, por se sentir-se incapaz de fazer o que quer. Para ilustrar esse sentimento, Carolina conta de uma prova que havia realizado para trabalhar como cuidadora de pessoas idosas, na parte de geriatria de uma instituição. Segundo a participante, sua nota havia sido mais alta do que a nota da pessoa que conseguiu o emprego, e ela sentiu vontade de pedir revisão de prova, mas não pediu por "não conseguir".

A participante expressa uma opinião bastante negativa a respeito das intenções das pessoas de sua rede social: acredita que as pessoas, em geral, não têm a intenção de ajudar, e sim de criticar. Nesse sentido, o medo de receber críticas também surgiu como um dos motivos para esconder o TA das pessoas. Todos os dados descritos anteriormente sentimento de culpa e incapacidade, desejo de autopunição, medo de se tornar dependente e medo de receber críticas - podem ser considerados fatores que, agindo de forma conjunta, resultaram no mecanismo de isolamento da participante. Carolina considera que o ato de se isolar evita que ela receba críticas constantemente, e por esse motivo ela prefere vivenciar a solidão a interagir com as pessoas de seu meio.

No que concerne às amizades, Carolina realiza uma diferenciação entre "amigos" e "amizades". A participante descreve as "amizades" como as pessoas que conhece e encontra esporadicamente, ou seja, relações distantes. Em contrapartida, "amigos" seriam aqueles mais próximos, com quem a participante poderia confidenciar suas intimidades. No entanto, a participante relata que não tem amigos.

Quanto ao relacionamento conjugal, Carolina relata que sempre havia sido bastante conturbado, mas piorou após a instalação do TA. A participante considera que, com o desenvolvimento do transtorno, se tornou uma pessoa muito agressiva e fechada, com baixa autoestima e sem vontade de viver. Para lidar com essas características que Carolina passou a apresentar, o marido, segundo o discurso dela, se distanciava. Dessa forma, o casal parece ter entrado em um círculo vicioso, onde um se fechava e o outro se distanciava, culminando na separação. Assim, a participante considera que o TA acarretou inúmeras perdas em sua vida: a perda do casamento, da autoestima, da alegria e da vontade de viver. No entanto, Carolina considera o ex-marido como um familiar com quem possui uma relação íntima.

Eu me tornei uma pessoa mais agressiva no começo... Ao mesmo tempo mais fechada... (...) Eu perdi tudo. Eu perdi minha alegria... Eu perdi meu casamento... (...) Eu perdi tudo. Ter bulimia... Foi uma das piores besteiras na minha vida. Porque eu não ganhei nada. 
Na relação com os filhos, Carolina relata que "descontava seu nervosismo" neles, ou seja, a participante sentia-se muito nervosa e batia muito nos filhos, principalmente no mais velho. Ela confidencia que antes mesmo de ter o primeiro filho, já era uma pessoa bastante nervosa e agitada, e vomitava à toa, mas não sabia que aqueles vômitos poderiam indicar a ocorrência de um TA. Assim, quando o primeiro filho nasceu, Carolina não sabia controlar suas emoções e acabava por descontar seus sentimentos negativos nele. $\mathrm{O}$ segundo filho, em contrapartida, não sofreu tanto com a falta de autocontrole da mãe, pois, segundo o discurso da participante, ela já "conhecia uma pouco mais a doença".

A realização de atividades de lazer era um hábito comum para Carolina antes da ocorrência do TA: costumava viajar com seu ex-marido, sair para bares, restaurantes, entre outros. No entanto, após a instalação do transtorno, a participante relata que costumava tentar fazer academia e natação, mas ficava triste ao lembrar-se de momentos e fatos que a incomodavam, e por isso provocava o vômito e parava de realizar atividades de lazer. Além disso, Carolina relata que "sempre viveu para o ex-marido", mesmo antes de ter filhos, e não tinha tempo de realizar outras atividades.

Deus surgiu no discurso da participante várias vezes como significativa fonte de apoio no enfrentamento do TA. Carolina relata que frequenta a igreja apenas esporadicamente e não conversa com ninguém de lá, apenas com Deus. Além disso, Deus também foi considerado um "acompanhante" da participante nas idas ao ambulatório.

A rede social de Carolina era composta por, pelo menos 13 pessoas, distribuídas entre os quatro quadrantes. Considera-se que se tratava de uma rede ampla, com adequada composição e pouca dispersão. Vale ressaltar que a participante inseriu as "pessoas que encontra na rua" e as "pessoas da igreja" nos quadrantes de Amigos e Comunidade, sem atribuir uma quantidade específica para o número de pessoas, o que dificultou a quantificação do número de membros da rede. No quadrante da Família, cinco pessoas foram inseridas nas Relações Íntimas (mãe, exmarido, uma irmã e os dois filhos) e três foram inseridas nas Relações Sociais (duas irmãs e o irmão). No quadrante do trabalho foi inserida a senhora de quem a participante cuida, na parte de Relações Íntimas. Na parte do GRATA, Carolina inseriu as pacientes vinculadas ao serviço, caracterizando-as como Conhecidas. Nota-se que, por mais que a participante tenha uma relação conflituosa com as outras pacientes do GRATA, ela as considera parte de sua rede social. Em termos de densidade, apenas a família tem contato entre si, denotando uma rede social de baixa densidade. 


\section{Participante 3 - Fernanda}

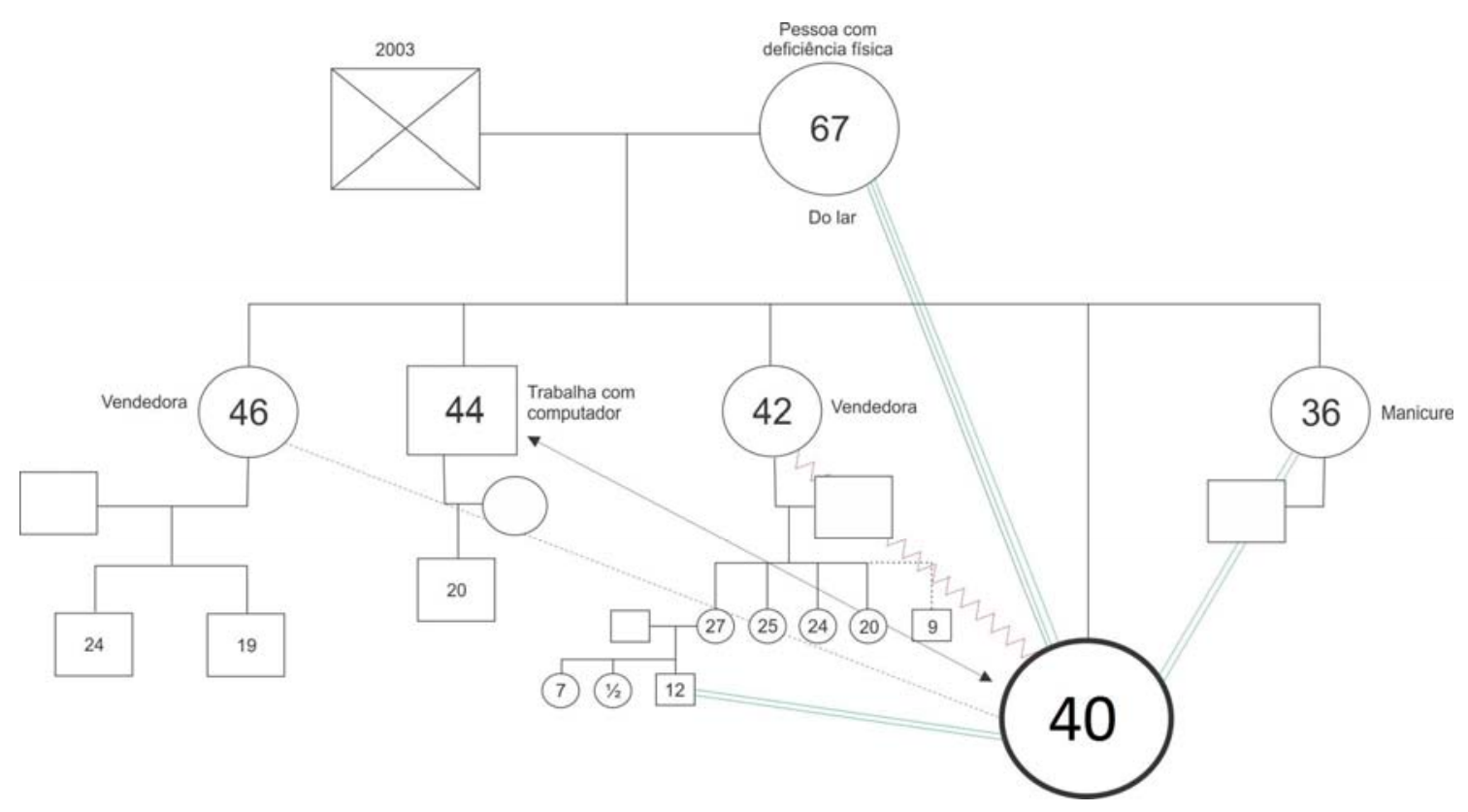

Figura 6. Genograma de Fernanda

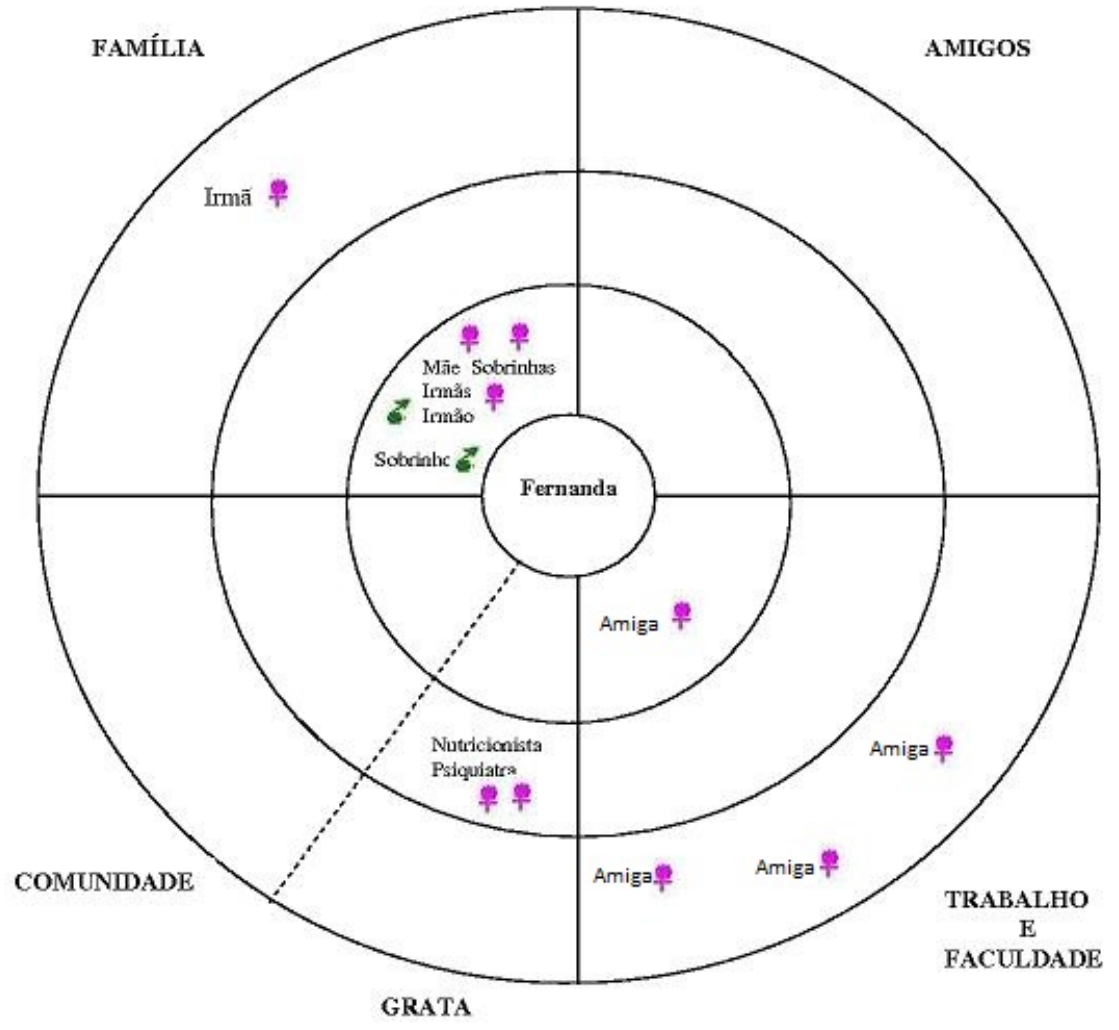

Figura 7. Mapa de Redes de Fernanda 
Segundo os dados do prontuário hospitalar, Fernanda foi encaminha ao serviço de nutrologia do HC após internação na UE, no ano de 1995, devido a um quadro de desnutrição grave. A participante pesava $51,9 \mathrm{~kg}$, tinha $1,74 \mathrm{~m}$ de altura e $\mathrm{IMC}=16,6 \mathrm{~kg} / \mathrm{m}^{2}$, característico do quadro e desnutrição apresentado. O diagnóstico atribuído à participante foi AN, quadro depressivo maior e possível transtorno de personalidade. Na época da internação, a mãe da participante relatou que a filha sempre foi tímida, isolada, com poucos amigos e nunca saía de casa. A participante, por sua vez, relatou que no ano de 1993, após a ocorrência de dois acontecimentos marcantes em sua vida - prisão da irmã por possessão de drogas, e ter sido abordada na rua por um homem que tentou estuprá-la -, notou que algumas de suas características pessoais se acentuaram: tornou-se mais tímida e retraída, pouco comunicativa, irritável, com baixo limiar à frustração, exaltando-se facilmente com outros familiares por motivos insignificantes, agressiva fisicamente com seus sobrinhos. Nessa mesma época, a participante relatou ter começado a frequentar academia e a fazer dietas, pois acreditava que estava gorda. Depois de um ano e meio, os sintomas de isolamento se agravaram, passando a ficar somente deitada em seu quarto. Apresentava-se mais nervosa, piscava rapidamente, torcia as mãos e tinha "visões". Às vezes ia até o cemitério, onde permanecia por algumas horas.

$\mathrm{Na}$ época da entrevista, Fernanda tinha diagnóstico de AN do tipo purgativo e transtorno de personalidade borderline, pesava $70,8 \mathrm{~kg}$ e tinha IMC de $23,15 \mathrm{~kg} / \mathrm{m}^{2}$. Segundo os dados do prontuário, a participante encontrava-se bastante ansiosa, queixava-se de cefaléia frequente e havia parado com as atividades físicas. Relatava que tinha períodos de compulsão alimentar seguidos de vômito, que ocorriam de três a quatro por mês. Considerava-se impulsiva, nervosa e explosiva. Relatava muita preocupação com o peso, e provocava o vômito como forma de alívio. Negava ideação suicida.

Durante a entrevista, Fernanda relata que vivencia "altos e baixos", ou seja, momentos de melhora e piora do quadro de TA: naquele momento, a participante considerava-se bem, mas relata que um mês antes se encontrava com bastante dificuldade para se alimentar, apresentando compulsão, seguida de vômitos induzidos. Segundo o discurso da participante, a compulsão alimentar está geralmente relacionada à ansiedade. Fernanda considera-se muito ansiosa e relata que não consegue parar quieta, e quando para, "ataca" a comida. Além disso, a angústia e a tristeza são sentimentos aos quais a 
compulsão alimentar também está atrelada. Fernanda relata que quando se sente triste, "precisa comer muito, e vomitar".

Ah, então... Eu sou muito ansiosa... É... Não consigo ficar quieta, fico o tempo todo trabalhando, quando eu não tô fazendo alguma coisa em casa, eu tô no trabalho, não tenho sossego, eu não consigo ler um livro, você entendeu? Não consigo parar pra ficar assistindo televisão, tem que tá o tempo todo assim, movimentando, fazendo serviço, entendeu? (...) A partir do momento que eu parava era... Eu já começava... Atacava mesmo a comida, sabe? 0 alimento... Qualquer alimento que eu via, já começava a comer, comer... Então, assim... Eu sempre fui muito ansiosa, eu não consigo assim, ficar parada, muito tempo, assim... Parada... Pra fazer as coisas assim, uma coisa calma... Ler um livro... Mais tranquila.

Após a ingestão excessiva de alimentos, Fernanda relata que costuma vivenciar sentimentos de culpa, solidão e vazio, além de um cansaço intenso devido ao nervosismo constante e à rotina "comer, vomitar, comer, vomitar". A participante confidencia que sempre se alimentou de forma excessiva, mas não sabia que se tratava de uma compulsão. No entanto, após a mudança de um estado distante para a casa onde reside atualmente, Fernanda relata que começou a desenvolver um quadro depressivo: perdeu a vontade de realizar as atividades diárias, não se olhava no espelho, sentia-se feia, sofreu um rebaixamento da autoestima e do tom da voz, sentia pavor de barulho e começou a perder peso. A participante relata também que, apesar dos apontamentos de seus pais, não percebia que estava passando por todas essas mudanças e sentia que estava gorda, e que precisava emagrecer.

Fernanda relata que sentiu muita dificuldade para se engajar no tratamento no GRATA, pois esse engajamento e a melhora do quadro implicavam no ganho de peso que ela tanto temia. Os grupos de apoio e o atendimento nutricional eram as partes do tratamento nas quais a participante mais sentia dificuldade, pois não conseguia "se expressar e falar sobre si mesma". Para não "encarar que tinha um problema e que precisava ser tratada", Fernanda relata que mentia nas consultas, dizendo que estava se alimentando bem. Entretanto, após alguns anos de tratamento, Fernanda percebe que teve melhoras, se sente satisfeita com o tratamento e com o acolhimento proveniente dos profissionais e relata que uma das fontes mais significativas de apoio que já teve ao longo de sua vida foi proveniente de uma das nutricionistas do GRATA. 
Um dos momentos mais marcantes vivenciados por Fernanda no tratamento foi uma vez em que ela realizou uma tentativa de suicídio. A participante relata que, naquela época, sentia que não queria mais viver, pois sua autoestima estava muito baixa, sentia-se muito sozinha e não tinha mais vontade de fazer nada. Tomou vários remédios e foi levada para o HC. Fernanda lembra-se da cena de sua mãe - que é portadora de deficiência física empurrando com dificuldade a maca sobre a qual a participante estava deitada, e relata que "não podia ter feito aquilo com a mãe". Nessa época de muito sofrimento, Fernanda considera que o apoio da nutricionista com quem fazia seguimento no GRATA naquela época foi fundamental. Atualmente, Fernanda considera que está melhor: sente que sua autoestima está mais elevada e tem procurado se engajar mais em atividades de lazer, tais como sair com as pessoas do trabalho.

A participante relata realizar poucas atividades de lazer, principalmente pelo fato de não ter muitos amigos. Essas atividades se resumem à ler livros, ouvir música e, eventualmente, fazer caminhadas. Quando questionada a respeito dessa escassez de amizades, Fernanda se denomina como "alguém que não é muito de ter amigos", ou seja, a participante possui características de personalidade retraída, que sempre dificultou o estabelecimento de vínculos ao longo de sua vida. Foi mencionada apenas uma amiga com quem Fernanda tem relação íntima, mas as duas não costumam sair juntas pelo fato da amiga ser casada. A participante relata que se sente bem assim, com uma rede social pequena, e não gostaria que fosse diferente.

No que concerne às relações familiares, Fernanda demonstra ambivalências acerca de sua relação com seus irmãos. Em um primeiro momento, a participante relata possuir uma relação próxima e harmônica com o irmão e com duas das irmãs, e uma relação conturbada com uma de suas irmãs: esta última trata-se de uma irmã que, segundo o discurso da participante, é bastante revoltada com a mãe por ciúme de seus filhos terem sido criados por ela. Fernanda, ao tomar as dores da mãe, briga e discute frequentemente com a irmã. No entanto, em um segundo momento, Fernanda relata que a relação entre os irmãos sempre foi distante, que "eles nunca foram de apoiá-la" e que ela gostaria que ela e os irmãos fossem mais unidos. Acredita-se que essa ambivalência expressa no discurso da participante seja decorrente de uma vulnerabilidade das relações familiares. Além disso, Fernanda relata que uma de suas irmãs costumava ser muito distante, mas se aproximou após a ocorrência do TA. 
É... Eu gostaria que nós fôssemos mais unidos. Você entendeu? Ao mesmo tempo que estão todos unidos daqui a pouco, assim... Estão... Brigados, entendeu? Tá todos desunidos.

A relação com a mãe foi caracterizada pela participante como "muito próxima": Fernanda relata que a mãe sempre esteve presente em sua vida e "sempre a acompanhou em momentos de dificuldade". No entanto, Fernanda relata que sua mãe é bastante dependente, em função da deficiência física e de outras condições clínicas que ela possui, tais como diabetes e hipertensão. Assim, nota-se que há uma relação de aliança entre mãe e filha, que é intensificada pela dependência decorrente da vulnerabilidade do estado saúde de ambas.

Porque a minha mãe é uma pessoa assim, muito cobrada, sabe? Os filhos têm ciúmes uns dos outros, sabe? Então, eles tão sempre cobrando a minha mãe e eu tô alí sempre defendendo a minha mãe, sabe? Que eu moro com ela, então tô sempre defendendo, mas a relação minha com elas são boas, elas vão sempre em casa, são bem recebidas, a gente conversa, aí de semana todo mundo conversa, tudo...

Fernanda considera que sua mãe, uma de suas irmãs e os profissionais do GRATA são suas principais fontes de apoio.

A rede social significativa da participante é formada por dezesseis pessoas, distribuídas entre os quadrantes da Família, Comunidade e Trabalho. Considera-se, então, que se trata de uma rede social ampla e com boa distribuição, mas com densidade baixa, uma vez que só há conexão entre os membros da família. No quadrante da família foram inseridas 10 pessoas, todas nas Relações Íntimas: duas irmãs, irmão, quatro sobrinhas, um sobrinho e a mãe. Nas Relações Distantes foi inserida uma irmã. No quadrante do Trabalho, foram inseridas quatro amigas, sendo três nas Relações Distantes e uma na Relação Íntima. Por fim, no quadrante da Comunidade, foram inseridas a psiquiatra e a nutricionista do GRATA, que fazem os atendimentos de Fernanda. 


\section{Participante 4 - Grazieli}

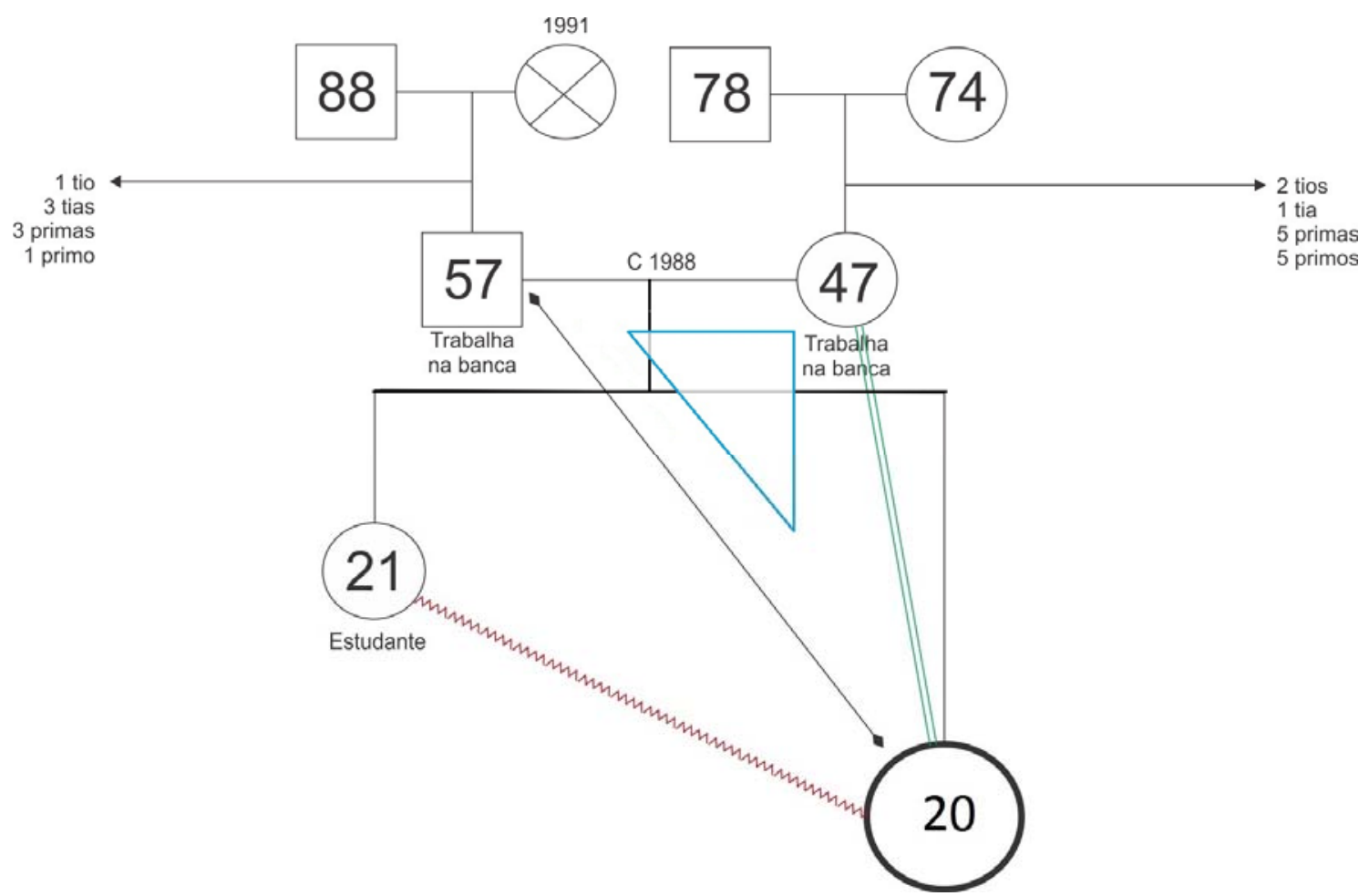

Figura 8. Genograma de Grazieli

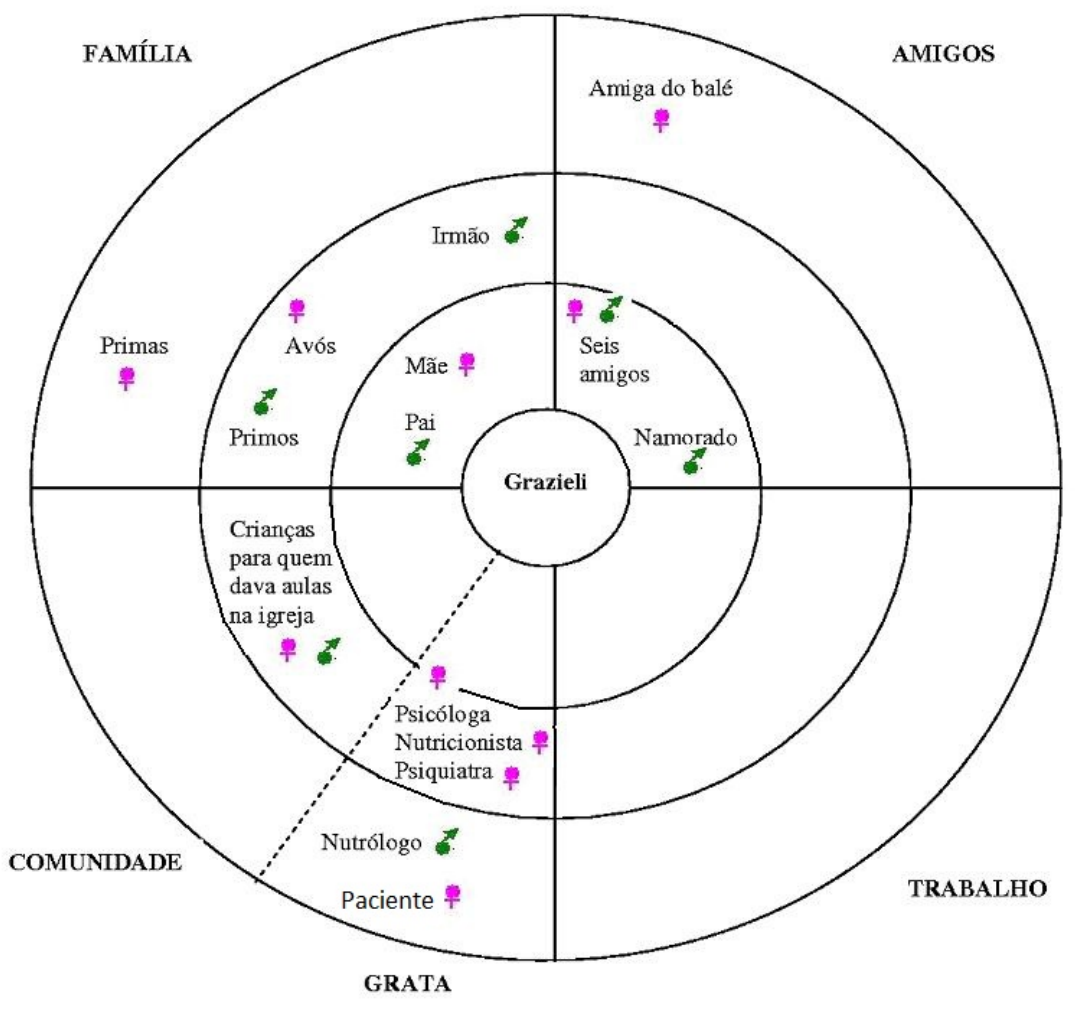

Figura 9. Mapa de Redes de Grazieli 
O tratamento de Grazieli no GRATA foi iniciado no ano de 2009, quando a participante tinha 18 anos. Ela apresentava $64 \mathrm{~kg}, 1,65 \mathrm{~m}$ de altura e IMC correspondente a $23,5 \mathrm{~kg} / \mathrm{m}^{2}$, ou seja, em termos clínicos, a participante encontrava-se dentro dos parâmetros normais. No entanto, segundo os dados do prontuário médico, Grazieli apresentava história de $\mathrm{BN}$ desde os 13 anos de idade, com episódios de compulsão alimentar seguidos de sentimento de culpa e indução de vômitos, que aconteciam de uma a duas vezes por semana. A participante relatava que fazia uso de laxantes também de uma a duas vezes por semana. Referia bastante ansiedade, humor deprimido e medo intenso de engordar.

$\mathrm{Na}$ época da entrevista, Grazieli relatava estar bem e tranquila, conseguindo seguir as orientações nutricionais. Entretanto, a participante relatava a indução ocasional de vômitos, aproximadamente três vezes ao mês. Em relação ao corpo, a participante relatava "estar suportando", mas se pudesse tentaria emagrecer. Estava namorando, e relatava estar tudo bem no namoro e em casa. Negava ideação suicida. Em termos antropométricos, Grazieli apresentava peso de $59,3 \mathrm{~kg}, 1,65 \mathrm{~m}$ de altura e $I M C=21,9 \mathrm{~kg} / \mathrm{m}^{2}$, considerado dentro da faixa de normalidade.

Durante a entrevista, a participante relata que suas dificuldades com a alimentação estão relacionadas com a falta de autocontrole, ou seja, quando a participante começa a comer, "não consegue comer uma coisinha só, acaba comendo exageradamente e não consegue ficar com aquilo no estômago". Esses episódios de compulsão se caracterizam, por exemplo, pela ingestão de uma panela inteira de feijão com farinha. Após esses episódios, o sentimento que Grazieli relata vivenciar é, principalmente, o "peso na consciência", seguido da indução de vômitos. No entanto, apesar dos sentimentos negativos vivenciados antes e após os episódios de compulsão alimentar, a participante relata que não consegue parar de pensar na alimentação.

E quando eu comia muito também, assim, era muito difícil... Parecia um vício. Eu não conseguia pensar em outra coisa, a não ser na comida... Pensava no que eu ia comer, ou pensava em um doce, alguma coisa que eu queria fazer... Ficava parecendo que a minha vida inteirinha girava em torno da comida... Eu não tinha vida. Era só comida, eu só pensava em comer. Aí eu ia dormir, às vezes o dia inteiro, me esconder assim, pra não comer, porque eu sabia que eu ia vomitar... Então qualquer coisinha que eu comia, eu vomitava.

É uma sensação de alívio, de tirar aquela coisa, assim, que tá dentro de você, mas dá uma angústia, uma tristeza de tá fazendo isso (...) Era algo que eu não 
controlava assim... Era coisa que... Eu vomitava, mas ao mesmo tempo, daqui a pouquinho, cinco minutos, dava vontade de encher de novo... Então, era um ciclo vicioso, que não parava.

Nota-se que a compulsão alimentar se encontra associada a afetos que a participante tem dificuldade para nomear. Segundo o discurso, os episódios de compulsão alimentar costumam ocorrer quando Grazieli se encontra sozinha. Ela relata que, nesses momentos de solidão, começa a "pensar em tudo" e sente angústia e tristeza, ou "às vezes não quer pensar em nada", e acaba por comer em demasia. Quando questionada a respeito desses pensamentos que surgem em sua mente quando se encontra sozinha, Grazieli relata que desde a pré-adolescência, quando começou a fazer balé, ouvia que ela precisava ser magra. Além disso, a participante também relata que, nessa época, tinha muitos sentimentos de solidão, e começou a relacioná-los com a sua forma e peso corporal.

No colegial. Eu estudava, depois ia pra casa, ficava o dia inteiro em casa... Ah, meus pais trabalhavam. Era mais isso, assim [...] Eu sentia solidão, eu me sentia como se eu não fosse bonita, ninguém me queria, porque eu era gorda, por isso ou aquilo outro...

Grazieli relata que passou por fases "muito perturbadoras" durante a adolescência, permeadas por sentimentos negativos que eram "colocados na comida", ou seja, demonstrados por meio das dificuldades com a alimentação.

Já teve época que... Que eu só chorava, pra mim não tinha, assim, uma esperança... Minha coisa era só comida, eu não conseguia dormir [...] Aí, eu tava meio assim, meio sem saber o que eu tava fazendo, meio assim, parecia que eu tava doida... Eu ia num lugar, numa sorveteria, eu nem sabia o que eu queria, eu só queria comer sem parar. Às vezes, comprava uma caixa de bombom e comia sem parar, e ia na sorveteria, assim, o moço: "O que você quer?", eu ficava meio assim, sem saber o que eu queria. Só queria alguma coisa pra comer e depois jogar fora, aliviar. Então, era uma fase muito perturbadora, assim. Eu não queria mais viver... Pensei em me matar, também...

Eu lembro que, muitas vezes, assim, eu colocava a angústia na comida. Eu queria... Toda angústia, toda frustração, eu queria comer, colocava raiva na comida, depois jogar aquilo, dava aquela sensação de alívio...

No entanto, no momento da entrevista, Grazieli relatou que se encontrava em uma fase mais tranquila. Os episódios de compulsão alimentar e de vômitos estavam ocorrendo 
em menor frequência, e a participante atribui essa melhora ao tratamento no GRATA e ao apoio proveniente da mãe. Quando questionada a respeito desse apoio, Grazieli disse que se sentia apoiada apenas pela mãe, e não pelo pai e pelo irmão, que "acham que é besteira" e dizem que Grazieli e sua mãe "estão procurando chifre na cabeça de cavalo". Ou seja, tanto o pai quanto o irmão de Grazieli não compreendem a extensão das dificuldades que ela vivencia em decorrência do TA e, por esse motivo, não fornecem apoio à participante. Grazieli refere que se sente muito triste e chateada com a forma como seu pai e seu irmão lidam com as suas dificuldades, e considera que a mãe é sua única fonte de apoio familiar.

É possível notar a existência de uma triangulação entre Grazieli e seus pais, caracterizada por uma relação de aliança entre mãe e filha, na qual a dupla atua em relação ao terceiro, o pai. Esse dado foi evidenciado pela atitude da mãe em unir-se à filha para apoia-la em um momento de sofrimento, agindo contra a vontade do pai. Hipotetiza-se que a triangulação possua a função de deslocar a atenção dos pais de seus próprios conflitos para o TA da filha.

Acredita-se que a raiva e a angústia que Grazieli relata que costumava "colocar na comida", assim como a ausência de apoio do pai e do irmão, possam estar relacionadas com a relação conturbada que a participante tem com estes. Ela confidencia que desde a infância brigava muito com o irmão e vivia "estressada porque tudo era dele, tudo era pra ele". Atualmente, a participante relata que não conversa muito com o irmão para evitar brigas, mantendo apenas uma relação social. Além disso, Grazieli também se sentia muito sozinha, pois os pais não costumavam ficar perto dos filhos. O pai costumava criticar o gosto de Grazieli pela dança de rua, afirmando que era "coisa de malandro", e acabou por tirá-la das aulas, deixando-a muito triste e com muita raiva.

De acordo com o discurso da participante na entrevista, foi possível perceber que a relação desta com o pai era bastante conturbada, permeada por brigas e discussões. Grazieli relata que se sentia muito frustrada e sufocada, pois o pai a prendia muito, "a colocava numa bolha". Ou seja, o pai não a deixava sair, ir às festas e nem dormir na casa das amigas. O sentimento vivenciado por Grazieli frente a essas atitudes do pai era raiva que, segundo ela, era descontada na alimentação. Outro aspecto que a participante considera como fator mantenedor do TA é o trabalho na banca dos pais. Grazieli se sente muito cobrada pelo pai durante o dia todo, e também por si mesma, uma vez que tenta a todo custo agradar seu pai. Ela relata que se trabalhasse em um lugar longe do pai, se sentiria menos cobrada e mais tranquila. 
O GRATA foi considerado como fonte significativa de acolhimento e apoio para Grazieli. Apesar da dificuldade de encarar a tristeza e as lamentações das outras pacientes durante os grupos de apoio, a participante considera que as pacientes que chegam felizes também podem "contagiar" as outras e despertar boas perspectivas.

Grazieli pontua uma diferença entre amigos e colegas: descreve os amigos como poucas pessoas com quem ela pode contar. Nesse sentido, nota-se a participante realiza uma diferenciação entre as pessoas significativas da sua rede de amizades, pois menciona os amigos e não inclui os colegas. Grazieli relata que, atualmente, tem seis amigos, sendo dois da igreja e quatro da escola, com quem se encontra e conversa frequentemente, tanto pessoalmente quanto por telefone e internet. Antes da ocorrência do TA, Grazieli relata que tinha mais amigos na escola, conversava com todo mundo. No entanto, na época em que o transtorno estava em uma fase mais grave, a participante confidencia que não conversava com ninguém, era muito calada e sozinha, e tinha apenas duas amigas que não sabiam do quadro.

Quanto ao namorado, Grazieli relata que ele é mais novo do que ela (tem 16 anos) e que o conheceu nas aulas de dança de rua, onde ele também fazia aula. Os dois namoram há seis meses e a participante descreve o relacionamento como "muito bom", sem entrar em maiores detalhes. O namorado também exerce o papel de companhia social para a participante, uma vez que os dois saem sempre juntos para boates, shopping e outros passeios.

A rede social significativa de Grazieli é formada por aproximadamente 21 pessoas, distribuídas entre os quadrantes da Família, Amigos e Comunidade. Considera-se que a rede é ampla, apresenta boa distribuição e alta densidade, uma vez que todos os membros têm conexão entre si. Vale ressaltar que a participante inseriu as "crianças para quem dava aulas na igreja" no quadrante da Comunidade e os primos e primas no quadrante da Família, sem atribuir uma quantidade específica para o número de pessoas, o que dificultou a quantificação do número de membros da rede. Não foram inseridas pessoas no quadrante de Trabalho e Estudos, apesar de alguns dos amigos (colocados no quadrante de Amigos) serem da escola. No quadrante da Família foram inseridas aproximadamente sete pessoas: avós, primos, primas, irmão, pai e mãe. No quadrante dos Amigos foram inseridas oito pessoas: namorado, seis amigos (sendo dois da igreja e quatro da escola) e uma amiga do balé. Por fim, no quadrante da Comunidade foram inseridas as crianças para quem Grazieli dava aula na igreja, e na parte do GRATA, foram inseridas a nutricionista, a psiquiatra, a psicóloga, o nutrólogo e uma paciente. 


\section{Participante 5 - Maria}

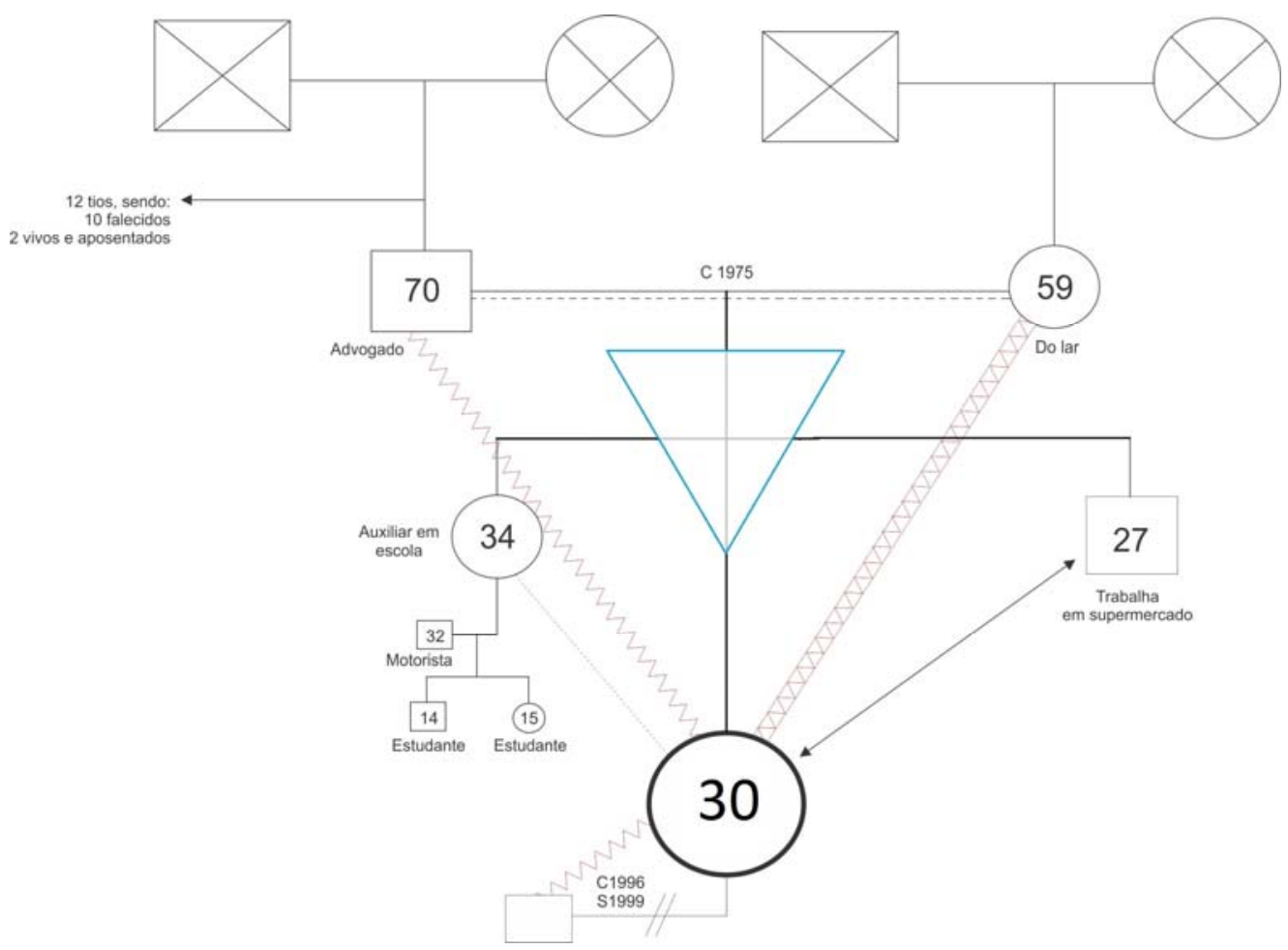

Figura 10. Genograma de Maria

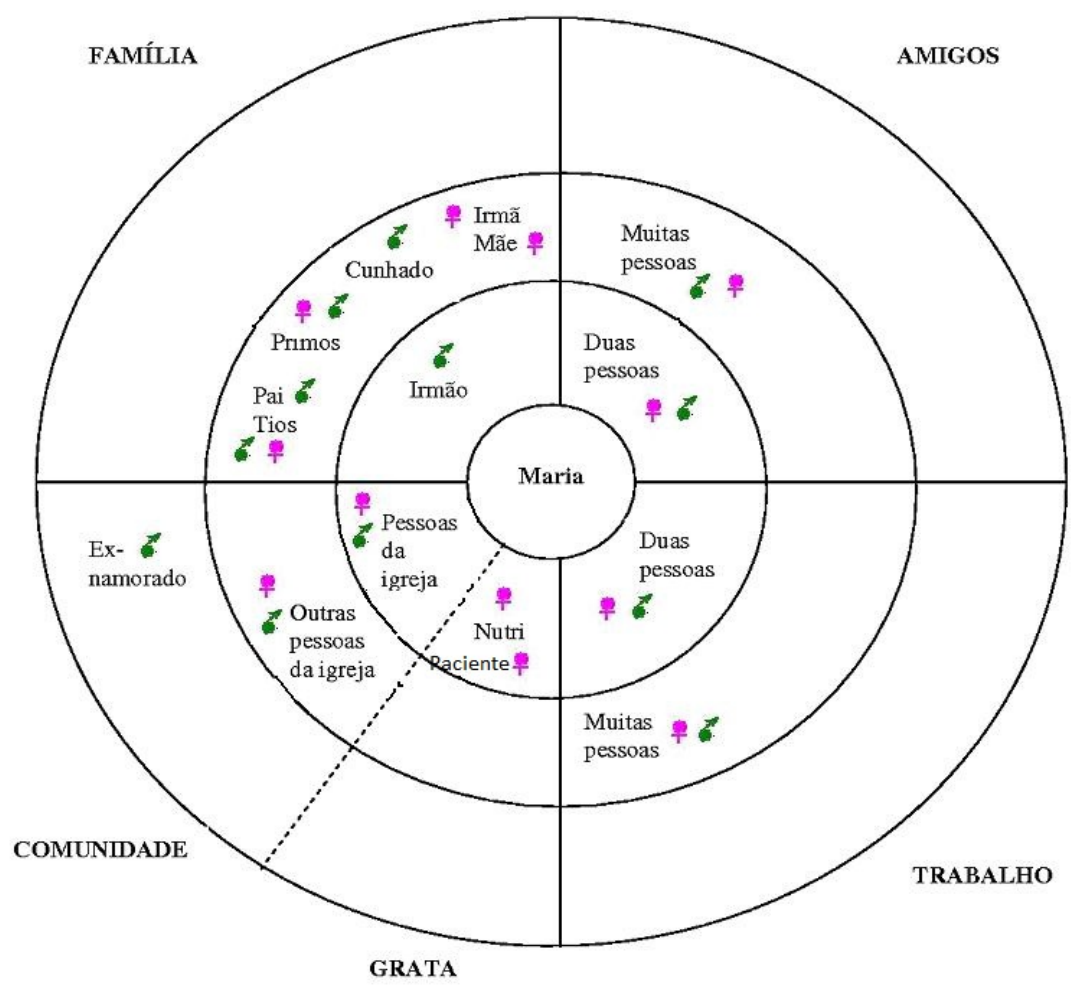

Figura 11. Mapa de Redes de Maria 
Segundo os dados do prontuário médico, Maria foi encaminhada para internação na UE do HC no ano de 2007, com diagnóstico de TA e episódio depressivo grave, com queda do estado geral. A participante, naquela época, relatava que sentia tristeza intensa, chorava facilmente e apresentava anedonia. Esses sintomas começaram a surgir no ano de 2004, juntamente com os sintomas de restrição alimentar, seguida de grave perda de peso. Nesse mesmo ano, a participante já fazia psicoterapia e começou a fazer tratamento psiquiátrico em sua cidade, encaminhada pela psicóloga. A participante afirmava que se alimentava de forma demasiada e discordava quando era criticada a respeito de comer pouco. Não se considerava magra, pelo contrário, ainda desejava perder três quilos. Ficava muito irritada com o assunto do peso, e não respondia à maioria das perguntas dos médicos. A participante recebeu alta em função de um ganho de peso, mas foi internada novamente no ano seguinte, apresentando piora dos sintomas depressivos, restrição alimentar e ideação suicida.

Maria iniciou o tratamento no GRATA a partir do encaminhamento realizado pela equipe responsável pela última internação. O encaminhamento aconteceu no primeiro mês de 2009, quando a participante referia muita revolta e ódio por ter recuperado peso durante a internação. A participante tinha 29 anos de idade, pesava $47,8 \mathrm{~kg}$, tinha $1,64 \mathrm{~m}$ de altura e $\mathrm{IMC}=17,8 \mathrm{~kg} / \mathrm{m}^{2}$, considerado abaixo da faixa de normalidade. Encontrava-se chorosa e descontente por esse motivo. Relatava sentir-se "um monstro de gorda", não suportava se olhar no espelho e desejava perder $10 \mathrm{~kg}$. Além disso, Maria também mencionava a realização de caminhadas diárias com duração de uma hora, visando à perda ponderal. Não havia retomado o tratamento psiquiátrico desde a internação de 2007. Referia descontrole sobre a alimentação e vontade de controlar melhor o que come. Apresentava ideação suicida e desejo de autoagressão.

Na época da entrevista, a participante estava em tratamento no GRATA há um ano e 10 meses. Apresentava diagnóstico de AN do tipo purgativo e transtorno de personalidade narcisista. Em termos antropométricos, Maria apresentava $49,1 \mathrm{~kg}$ e IMC $=18,3 \mathrm{~kg} / \mathrm{m}^{2}$, ainda considerado abaixo da faixa de normalidade. Segundo os dados do prontuário de Maria, ela se sentia muito ansiosa e apresentava agravamento dos pensamentos obsessivos. A participante atribuía essa piora ao fato de haver terminado um namoro recentemente. Apresentava-se frustrada, pois desejava namorar sério, casar, ter filhos, e acreditava que não iria conseguir. Negava tristeza diária, anedonia, angústia e irritabilidade. $\mathrm{O}$ trabalho era 
um fator que despertava muita angústia e ansiedade na participante, mas ela havia mudado de trabalho, e relatava sentir-se melhor. No que concerna à alimentação, Maria relatava sentir mais prazer e menos culpa ao se alimentar. Negava ideação suicida.

Durante a entrevista, a participante relata que se sente bem atualmente, principalmente no que tange à sua relação com o alimento. No entanto, Maria relata que, antes de apresentar essa melhora, vivenciava lutas internas constantes, pois tinha medo de que qualquer alimento, por menor que fosse, iria fazê-la engordar. Além disso, Maria também relata que a vivência dessas lutas internas contra o alimento, as internações, as situações de angústia, dor, sofrimento e choro, e as brigas com a família serviram para que, aos poucos, ela pudesse "enxergar as coisas de uma forma diferente", ou seja, ao longo do tratamento a participante pôde ressignificar a sua relação com a alimentação e com o próprio TA.

Ah, eu passei muita situação, passei muita... Muita luta interna comigo mesmo, passei muita situação de... De angústia, de sofrimento, de dor, de choro, de briga com família, de internação em hospital... Muita coisa.

Ah, eu acho que, de tanto tratamento, tanta terapia, tanta... Todas as circunstâncias que eu passei, eu acho que ajudaram, me ajudaram a... A enxergar as coisas de uma forma diferente, me ajudaram a... Parece que a mente abre, a gente vai abrindo... Vai enxergando.

Maria considera que a época mais difícil de sua vida foi durante o ano de 2007, quando passou pela primeira internação. A participante relata que apresentava quadro de depressão e não conseguia trabalhar e nem se concentrar, chegando a tirar licença do trabalho. Ela se sentia "esmagada", pois não suportava a carga de trabalho e nem o chefe, que se tratava de alguém bastante autoritário e difícil de lidar. Maria relata que a maior dificuldade durante esse período foi a internação e "não aceitar que aquilo era para o seu bem". A participante desejava emagrecer cada vez mais, então se sentia incapaz de aceitar a ajuda proveniente da internação, uma vez que essa ajuda implicava no ato de se alimentar e, consequentemente, no ganho de peso.

Além disso, a participante também relata que, naquela época, encontrava-se bastante comprometida emocionalmente, em função de inúmeros eventos ocorridos desde a sua adolescência. Maria demonstrou-se bastante desconfortável quando questionada a respeito desses "eventos" ocorridos durante a adolescência e preferiu não aprofundar no 
assunto, mas acredita-se que esses eventos englobem o casamento da participante, que aconteceu quando esta tinha 16 anos e teve duração de três anos. Segundo os dados do prontuário médico, a participante estava grávida antes do casamento, mas houve um aborto e o bebê não chegou a nascer. Acredita-se que pelo fato de Maria não gostar de falar sobre o assunto, os dados do prontuário encontram-se incompletos acerca da questão do aborto, ou seja, não consta no prontuário informações a respeito de se o aborto foi forçado ou espontâneo, e nem os motivos da ocorrência do mesmo.

Durante a entrevista, Maria afirma já ter sido casada e caracteriza o relacionamento como "muito difícil", permeado por brigas e discussões. A participante relata que o exmarido "não aceitava o seu jeito de ser, a sua personalidade". No entanto, a participante procurou não aprofundar muito no assunto e negou a ocorrência de gravidez.

No que concerne ao tratamento, Maria menciona que pôde "evoluir bastante", ou seja, a participante considera que o tratamento exerceu um papel crucial na melhora do quadro psicopatológico. No entanto, a participante também menciona dificuldades na participação dos grupos de apoio do GRATA, pois considera-se "muito fechada" e tem "dificuldade para falar em grupo". Além disso, as internações foram citadas por Maria como sendo a parte mais difícil do tratamento, pois além da dificuldade em aceitar a alimentação, a participante "perdia a sua liberdade, não podia sair, não via a família todos os dias, quebrava a sua rotina e ficava presa em um lugar". Uma paciente do GRATA e a nutricionista que faz o seguimento de Maria foram consideradas pessoas íntimas e fontes significativas de apoio para a participante.

O sentimento que Maria mais vivenciou após a instalação do TA foi raiva. A participante menciona na entrevista que sentia raiva de tudo, principalmente do que estava relacionado à alimentação. Sentia muita dificuldade em aceitar que precisava "comer para sobreviver", mas "não queria comer de jeito nenhum". Nota-se, então, que Maria vivenciava uma ambivalência entre seus anseios pelo emagrecimento e a necessidade de se alimentar para sobreviver.

Maria considera que sempre teve amigos e "pessoas chegadas". Atualmente relata que possui relações de amizade bastante "fortes e íntimas", principalmente com pessoas do trabalho e da igreja que costuma frequentar. Trata-se de pessoas que sabem do TA e com quem a participante possui contato frequente, com conversas diárias e íntimas. A participante encontrava-se solteira na época da entrevista, mas relata que namorava até 10 
dias antes. Tratava-se de um relacionamento "complicado", pois Maria gostaria de ter um "relacionamento sério e compromissado", e o ex-namorado era "meio descompromissado". No entanto, o namoro não havia tido um término de fato: Maria relata que os dois haviam brigado e nunca mais conversado, então ela presumia que eles não namoravam mais, e encontrava-se triste por isso. Apesar do ex-namorado trabalhar no supermercado que a participante frequenta, os dois se veem semanalmente, mas não conversam.

A participante relata que realiza poucas atividades de lazer, considera-se uma pessoa "caseira". Uma delas é o artesanato, que se trata de uma atividade autônoma e solitária, da qual a participante tem prazer em realizar. A outra atividade de lazer é frequentar a igreja, e principalmente participar do coral, que é "muito bom e interativo".

No que tange às relações familiares, o irmão foi mencionado por Maria como o membro "não completamente íntimo, mas mais chegado", ou seja, trata-se de alguém com quem a participante mantém uma relação diária e cúmplice. Quanto aos pais, Maria caracteriza a relação como "amigável, de respeito, mas não íntima". A participante relata que já vivenciou muitos conflitos com os pais, principalmente na época de maior gravidade do TA, pois os pais "tentavam fazê-la enxergar as coisas e ela não aceitava".

Ah, eu acho que eles tiveram que lutar demais comigo. Sabe, pra me fazer... Me tratar... Pra me fazer enxergar as coisas... Era uma luta constante, sabe? Era... Era uma luta pra me levar pra psicóloga, era uma luta pra me levar pro psiquiatra, era uma luta pra me fazer comer, era uma luta pra me fazer tomar remédio... Então, pra eles... Era muito complicado.

Atualmente, a frequência desses conflitos é consideravelmente menor, mas o relacionamento da participante com os pais não é considerado íntimo. Segundo o discurso de Maria, a relação com o pai sempre foi mais distante, pois ele era bastante autoritário e a participante considerava difícil desenvolver uma relação de intimidade com ele. Quanto à mãe, Maria relata que "teve uma época, bem antes de surgir a doença", em que as duas tinham uma relação mais próxima. Entretanto, ela considera que essa relação foi se desgastando em função dos conflitos decorrentes do TA, que eram bastante frequentes. $A$ participantes não expressa incômodo com as relações familiares distantes, pelo contrário: relata que gosta que sejam dessa forma. 
Evidenciou-se a ocorrência de uma triangulação entre Maria e seus pais, caracterizada por uma relação fundida e conflitual entre mãe e filha, que possui a função encobrir a relação emocionalmente distante do casal parental.

Ao final da entrevista, Maria lembrou-se de mencionar que tem uma irmã. Trata-se de uma irmã casada e que tem dois filhos, com quem Maria relata possuir uma relação saudável, mas não íntima.

Apesar dos conflitos já vivenciados com os pais e de não se sentir compreendida por eles, Maria os considera como as principais fontes de apoio, juntamente com o irmão, duas pessoas da igreja e uma do trabalho. O GRATA também foi mencionado como significativa fonte de apoio. No entanto, a participante relata que, hoje em dia, "consegue caminhar mais com as próprias pernas".

A rede social significativa de Maria é composta por aproximadamente 20 pessoas, distribuídas entre todos os quadrantes do Mapa de Redes. Considera-se que se trata de uma rede ampla, bem distribuída e pouco dispersa. Vale ressaltar que a participante inseriu "pessoas da igreja" no quadrante da Comunidade, "tios" e "primos" no quadrante da Família e "muitas pessoas" nos quadrantes de Amigos e de Trabalho, sem atribuir uma quantidade específica para o número de pessoas mencionadas, o que dificultou a quantificação do número de membros da rede. A maioria das pessoas da rede foram inseridas no quadrante da Família, nas Relações Sociais: mãe, pai, irmã, tios, primos e cunhado. Apenas a relação com o irmão foi considerada Relação Íntima. Maria mencionou possuir muitos amigos e colegas com quem possui Relação Social, mas apenas dois com quem possui Relação Íntima. No quadrante da comunidade, a participante inseriu o ex-namorado como Conhecido, e algumas pessoas da igreja como Relação Íntima e outras como Relação Social. Por fim, na parte do GRATA, Maria inseriu uma paciente e a nutricionista como Relações Íntimas. 


\section{Participante 6 - Sissi}

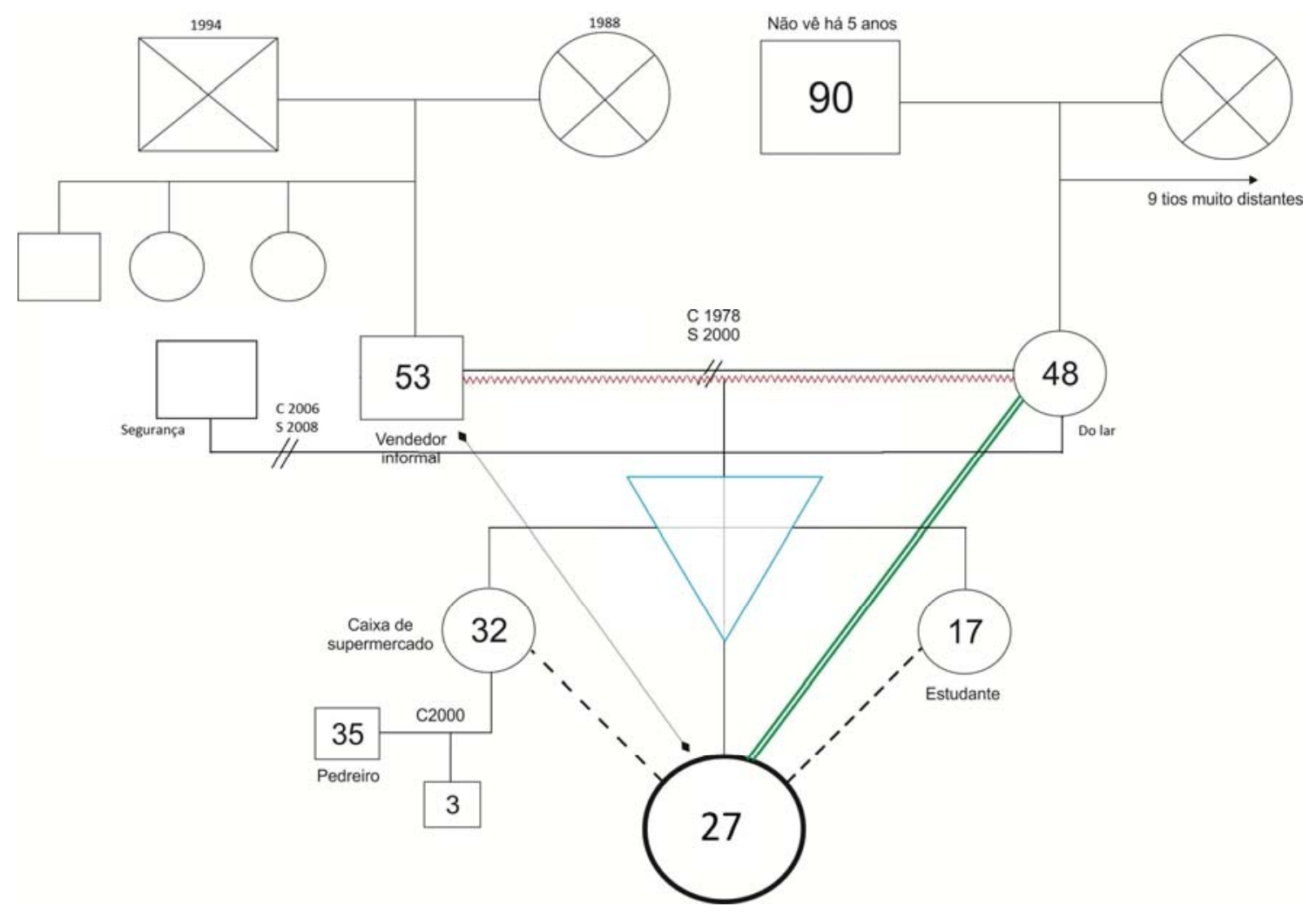

Figura 12. Genograma de Sissi

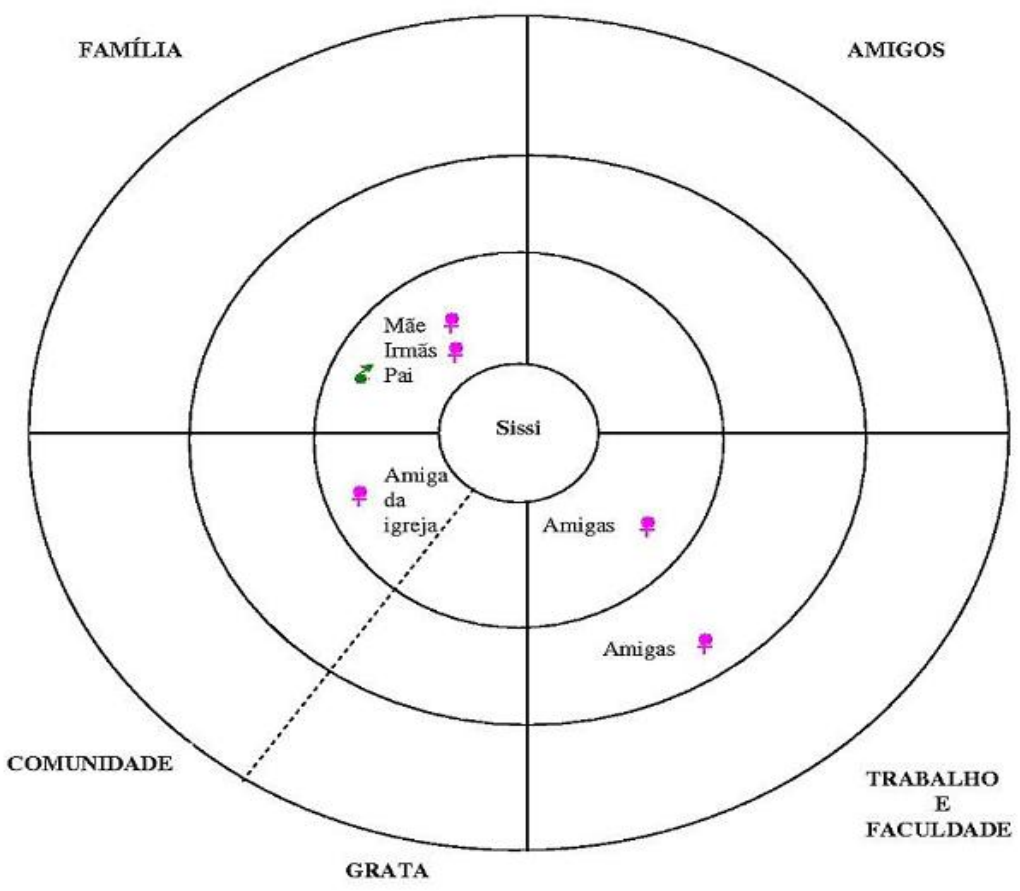

Figura 13. Mapa de Redes de Sissi 
Sissi procurou o GRATA em função de um quadro de compulsão alimentar seguido de vômitos e realização de exercícios físicos intensos. A participante tinha 26 anos de idade, e relatou que tinha esse problema há 10 anos, desde a separação dos pais. Com esse acontecimento, segundo os dados do prontuário médico, a participante ganhou aproximadamente $10 \mathrm{~kg}$, com piora progressiva dos sintomas de compulsão e purgação. No ano de 2007, a participante relatou ter vivenciado a pior fase do problema, pois vomitava de 10 a 12 vezes por dia, comia de forma bastante excessiva (por exemplo, três caixas de bombons e três pacotes de bolacha de uma vez, e vários potes de sorvete seguidos). Essas dificuldades culminavam em uma dificuldade de frequentar a faculdade, pois passava a maior parte do tempo vomitando, e apresentava pensamentos obsessivos de emagrecimento. Nunca havia procurado tratamento antes. Na época do início tratamento, Sissi pesava $65,1 \mathrm{~kg}$, tinha $1,75 \mathrm{~m}$ de altura e $I M C=21,2 \mathrm{~kg} / \mathrm{m}^{2}$, considerado dentro da faixa de normalidade. O diagnóstico atribuído à participante foi de $\mathrm{BN}$, em comorbidade com transtorno de personalidade borderline e traços histriônicos.

A entrevista com Sissi foi realizada um ano após a entrada da mesma no serviço. Segundo os dados do prontuário, a participante referia estar se sentindo bem, e negava tristeza, anedonia, angústia e instabilidade. Entretanto, relatava vários episódios de comer compulsivo. Sentia-se culpada quando comia alimentos muito calóricos, mas não realizava rituais purgativos. Referia maior controle sobre a impulsividade. Em relação aos dados antropométricos, Sissi pesava $63,4 \mathrm{~kg}$ e o IMC correspondia a $20,6 \mathrm{~kg} / \mathrm{m}^{2}$.

Partindo-se do discurso da participante na entrevista, foi possível notar que ela relaciona os episódios de compulsão alimentar com os momentos em que se encontra muito nervosa. Esse nervosismo, por sua vez, está relacionado a um alto grau de perfeccionismo e cobrança que a participante exerce sobre si mesma, principalmente no que tange às notas obtidas no curso universitário. Além disso, a participante também atribui a ocorrência da compulsão alimentar à necessidade de "preencher um vazio que sente". Ou seja, a participante vivencia um sentimento de tristeza, que traz consigo um sentimento de vazio, e que ela tentar "burlar" por meio da compulsão alimentar seguida de vômitos, ou da realização de outras atividades, tais como exercícios físicos.

Eu me cobro demais, sou muito perfeccionista e às vezes eu não atinjo as notas que eu quero atingir... [...] Eu me cobro demais, sabe? Tô sempre me cobrando... E na maioria das vezes, é isso, mas outras vezes é um vazio que eu sinto e fico tentando preencher... Um vazio... 
Não sei o que que é... Eu fico triste, sinto um vazio e não sei o que fazer pra melhorar... Agora que eu tô controlada com os remédios eu não sinto mais vontade vomitar, mas na época assim que eu não fazia o tratamento, eu tentava às vezes, é... Burlar esse sentimento com outra atividade.

Sissi relata que já passou por fases de melhora e piora dos sintomas do TA. Considera que a pior fase aconteceu no ano de 2007, quando se mudou de sua cidade de origem e passou a morar sozinha para cursar a universidade. Nessa época, a participante relata que sentia muita falta da mãe e "começou a vomitar mais e a perder todo o controle". No entanto, Sissi também considera que tem momentos de melhora, que estão relacionados com o uso dos medicamentos indicados pela psiquiatra do GRATA e com as visitas à igreja. A participante relata que, quando vai à igreja, procurar pensar que está apenas passando por uma fase difícil que ser superada, e assim "se fortalece, se sente esperançosa e consegue se reerguer".

A compulsão alimentar e os vômitos, segundo o discurso de Sissi, costumavam comprometer tanto a assiduidade nas aulas da faculdade quanto os relacionamentos interpessoais. $\mathrm{O}$ isolamento era a medida mais adequada que a participante encontrava para lidar com suas dificuldades, uma vez que ela não gostava de sair com os amigos e com o exnamorado, pois "sabia que iria vomitar". Quando acontecia da participante sair com essas pessoas, criava estratégias para ir ao banheiro vomitar, tais como falar ao celular. Dessa forma, Sissi passou a evitar sair com os amigos e a frequentar as aulas da faculdade, diminuindo assim os contato interpessoais e o tamanho de sua rede social.

Apesar de evitar os relacionamentos interpessoais, Sissi não demonstra sofrimento vinculado ao isolamento. A participante relata que tem muitos amigos, o que indica que a estratégia de se isolar não é utilizada o tempo todo, apenas em situações e momentos específicos, tais como quando a participante quer evitar sair para não comer ou não vomitar. Entretanto, as relações pessoais de Sissi são caracterizadas por ela como "não tão grudadas, mas também não tão distantes". Além disso, a participante relata necessitar de momentos solitários, ou seja, tem o hábito de visitar a casa das amigas quando convidada, mas não costuma ir sempre, e nem costuma convidá-las para ir à sua casa. Sissi relata que mora sozinha exatamente por gostar de vivenciar momentos de solidão.

Em termos de atividades de lazer, Sissi relata que não tem tempo de realizá-las, uma vez que também trabalha como funcionária pública em meio período. Na época em que a 
entrevista foi realizada, a participante encontrava-se de férias da faculdade e do trabalho, e por esse motivo relata que estava podendo realizar mais atividades de lazer. No entanto, as duas únicas atividades que a participante citou foram passar alguns dias na casa da mãe e ir à igreja. A ocorrência do TA não foi relacionada com a ausência de atividades de lazer, considerando que a participante realizava aulas de dança do ventre, frequentava a academia, corria, tomava sol e frequentava bares e festas quando já apresentava o quadro. Sissi relata que parou de realizar essas atividades em função do cansaço que sente pela rotina, que envolve estudo e trabalho. Sente não tem mais disposição, mas demonstra o desejo de realizar mais atividades de lazer para se inserir mais em sua rede social, uma vez que permanece muito tempo em casa.

$\mathrm{Na}$ relação com o alimento, Sissi relata que "está sempre se protegendo". A participante confidencia que ganhou um fogão com botijão de gás de seus pais, mas não os utiliza, e que a geladeira está quebrada há oito meses. Além disso, Sissi não deixa alimentos em casa e procura se alimentar sempre "na rua". Essas atitudes em relação ao alimento podem ser consideradas estratégias para evitar a compulsão alimentar, uma vez que a participante costumava comer todos os alimentos que tinha em casa "quando dava crise", mesmo que fossem alimentos que durariam o mês inteiro. Hoje em dia, Sissi "não faz estoque de nada".

No que tange ao tratamento no GRATA, Sissi apontou a participação da família como uma das partes mais significativas. A participante relata que seu relacionamento com o pai era bastante distante, mas a exigência de que os pais participem do tratamento foi considerada como uma oportunidade da participante se aproximar deste, dividindo com ele as questões a respeito do TA e podendo, assim, contar com o seu apoio. Além disso, a relação da participante com o pai era permeada por uma tendência à culpabilização deste, já que os sintomas do TA começaram a aparecer a partir da separação dos pais que, segundo Sissi, aconteceu por culpa do pai. Tratou-se de uma separação litigiosa, na qual o pai perseguia a esposa, era adúltero e fisicamente violento. Sissi considera que "cresceu com transtorno de paternidade", denotando que sentia muita raiva, medo e revolta do pai. Todos esses sentimentos negativos culminaram em um distanciamento do pai e em uma aliança com a mãe. Nota-se a ocorrência de uma triangulação, na qual o TA de Sissi surge com a função de distrair os pais de seus problemas conjugais para, talvez, evitar a separação do casal. 
Atualmente, graças à participação dos pais no tratamento, a participante relata que se sente mais próxima do pai e pôde reconstruir a relação de forma positiva, ainda que existam alguns conflitos.

O meu pai sempre foi um pai muito violento, batia na minha mãe... Eu sempre vi, ele sempre foi adúltero e... Eu sempre cresci muito revoltada, eu e minhas irmãs... Aí, quando eles largaram, ele tentou matar minha mãe... E aí, foi nessa época que eu fiquei... Que aconteceram muitas coisas... Porque foi uma separação litigiosa... Aí... A gente sempre cresceu na minha casa... Sempre cresceu com... Com transtorno de paternidade... Sempre com medo do meu pai...

A mãe de Sissi foi considerada sua principal fonte de apoio. Entretanto, a participante não realizou comentários extensos a respeito da relação com a mãe, limitando-se a relatar que as duas são muito próximas e que ela encontra-se satisfeita com o apoio recebido dela.

Quanto à relação com as duas irmãs, Sissi as considera íntimas. Entretanto, no que concerne ao TA, as relações fraternas da participante foram consideradas distantes, uma vez que esta não sabe se as irmãs têm consciência de seu quadro psicopatológico. Sissi relata que nunca contou sobre o TA para as irmãs, mas não sabe se a mãe acabou por contar. Descreve que elas e as irmãs "são meio tabu nessa parte". Quando questionada a respeito do motivo de não contar às irmãs sobre o TA, Sissi menciona a questão da vergonha, que se caracteriza como um dos sentimentos mais vivenciados pela participante desde a instalação da BN.

Sissi relata sentir-se muito envergonhada e arrependida por possuir um TA, pois costuma pensar frequentemente nas pessoas que passam fome e compará-las consigo mesma, que "está jogando alimento fora". A participante também sente nojo de si mesma, uma vez que o próprio ato de vomitar gera "desprezo e asco". Além disso, a participante sente-se tomada por pensamentos obsessivos relacionados ao alimento: relata que não consegue comprar um alimento sem antes ler a quantidade calórica que contida, sempre pensa que vai engordar se for a um determinado lugar, sempre repara no peso das pessoas e sempre considera que "quem é gorda, é infeliz". Nota-se, então, que a participante se sente perseguida pelo alimento a todo momento.

A participante se considera muito impaciente, intolerante, brava, "mandona" e determinada, e relata que gosta que as coisas sejam sempre "do seu jeito". Por esse motivo, considera que as pessoas de sua rede social têm dificuldade para lidar com seu jeito de ser, e 
os relacionamentos interpessoais íntimos são geralmente permeados por brigas e discussões. Sissi relata a percepção de que costuma "destruir relações" com o seu jeito de ser. Quando questionada a respeito das mudanças que gostaria que acontecessem em sua via, a participante relata que gostaria de ter sido uma pessoa mais tolerante durante a sua adolescência, pois dessa forma teria evitado inúmeros conflitos.

A rede social significativa da participante é formada por aproximadamente sete pessoas, distribuídas entre os quadrantes de Família, Estudo e Comunidade. As amigas da faculdade foram inseridas no quadrante de Estudo, de acordo com a forma com que a participante preferiu. Vale ressaltar que a participante inseriu as amigas da faculdade, sem atribuir uma quantidade específica para o número de amigas, o que dificultou a quantificação do número de membros da rede. No quadrante Família, foram inseridos quatro membros: mãe, pai e as duas irmãs. No quadrante da Comunidade, foi inserida apenas uma amiga da igreja. Considera-se que a rede social de Sissi tem tamanho pequeno e baixa densidade, uma vez que apenas as irmãs e a mãe têm conexão entre si. 


\section{Participante 7 - Sofia}

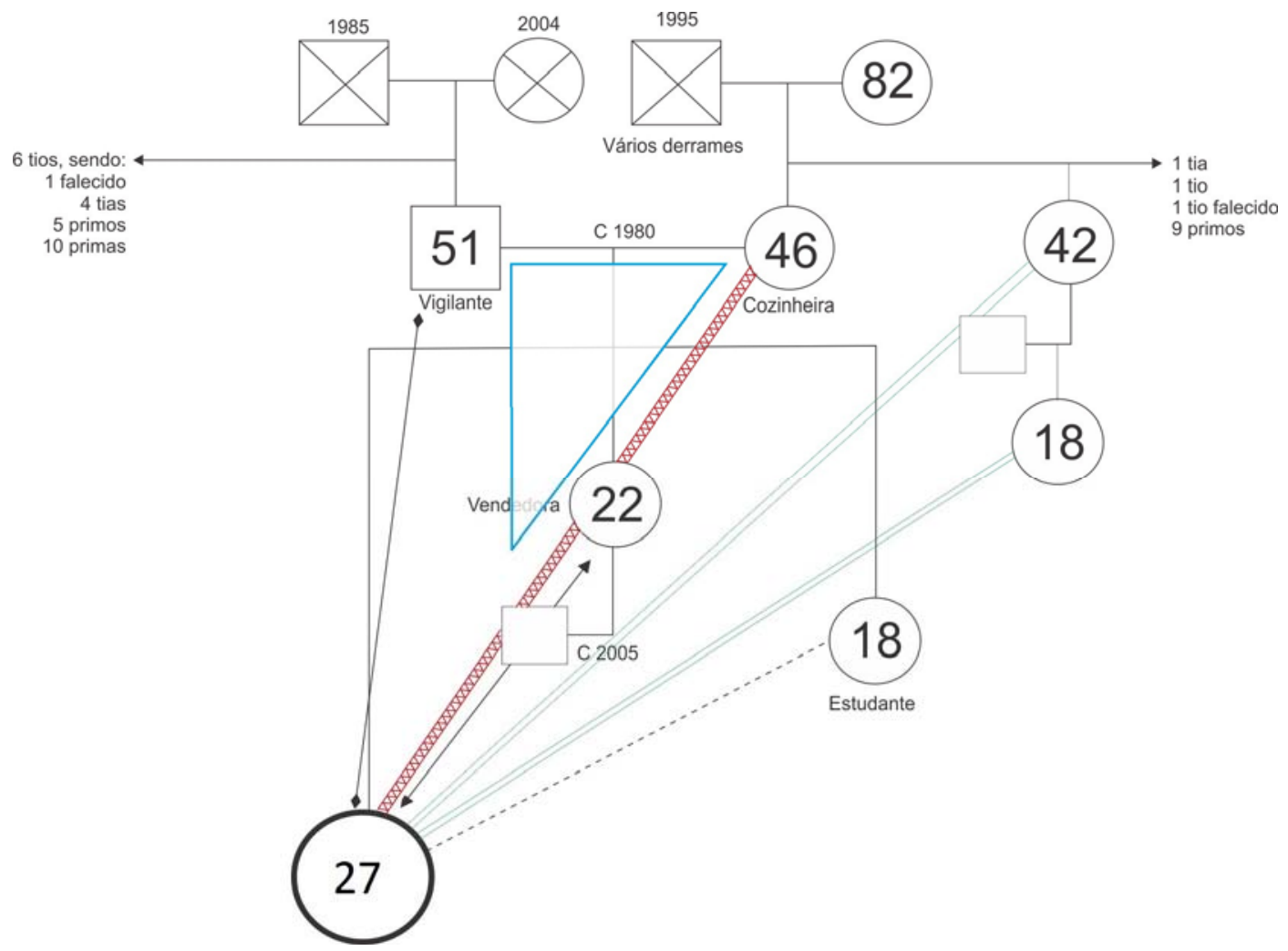

Figura 14. Genograma de Sofia

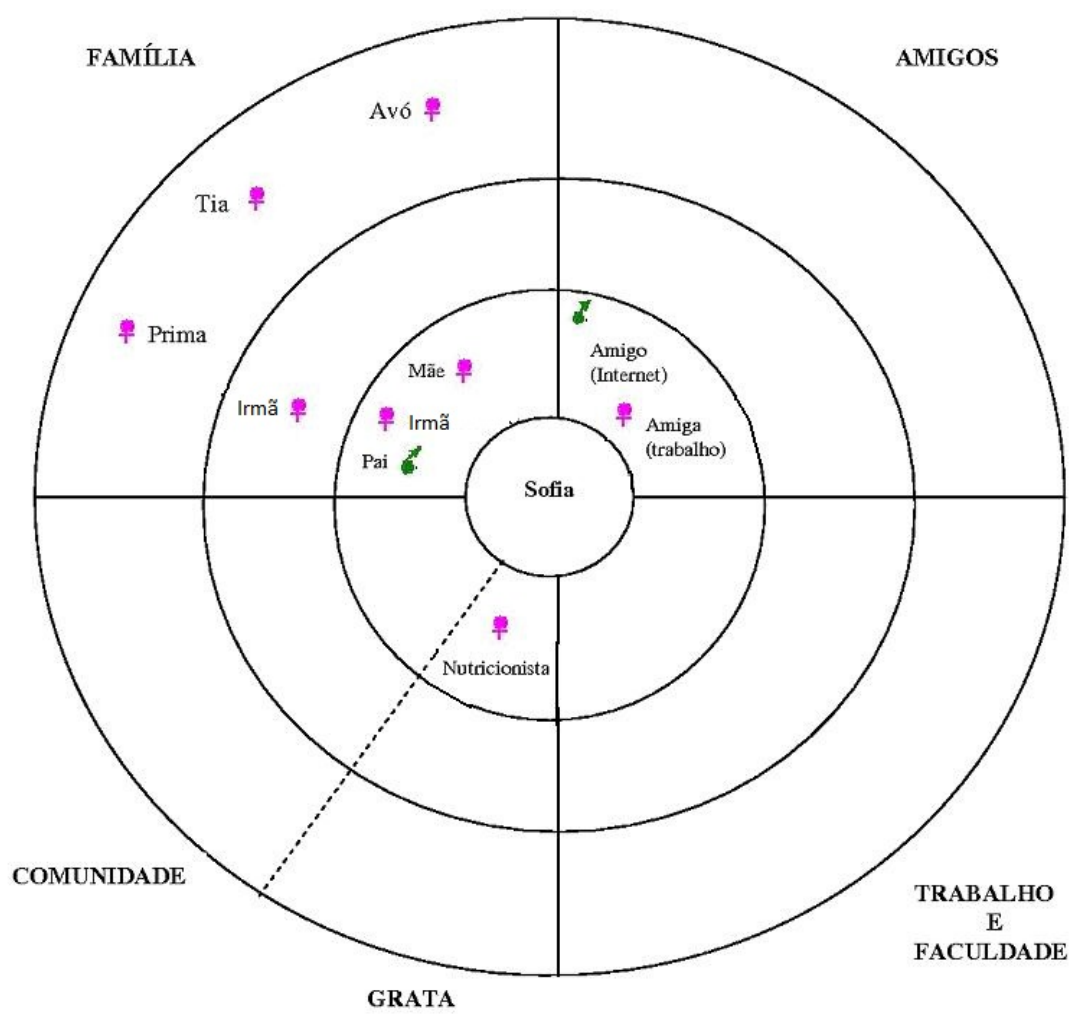

Figura 15. Mapa de Redes de Sofia 
Segundo dados do prontuário hospitalar, Sofia procurou a Unidade de Emergência (UE) do Hospital das Clínicas com quadro de AN do tipo purgativo e episódio depressivo maior, que havia sido diagnosticado dois meses antes. Referia fraqueza, palpitação, desânimo, anedonia, insônia e pensamentos de morte. Relatava não sentir fome nem vontade de comer, ingeria apenas líquidos. Não considerava que estava abaixo do peso, sentia-se gorda e apresentava distorção de imagem corporal. A participante permaneceu internada na UE durante seis dias, e já havia sido internada anteriormente, em novembro do ano de 2009, com o mesmo diagnóstico. Após a internação na UE, a participante foi encaminhada para o Hospital Dia (HD), onde esteve internada durante quatro meses.

O tratamento no GRATA foi iniciado um mês após o encaminhamento de Sofia para o HD. Nessa época, a participante apresentava $43,5 \mathrm{~kg}, 1,71 \mathrm{~m}$ de altura e $I M C=14 \mathrm{~kg} / \mathrm{m}^{2}$, considerado muito abaixo da normalidade e característico de casos de desnutrição. Fazia atividade física durante duas horas por dia, mas parou por sentir-se cansada e sonolenta. Negava vômitos, mas fazia uso semanal de laxantes - aproximadamente três comprimidos por semana. Apresentava grave distorção da imagem corporal e realizava restrição alimentar intensa. Fazia acompanhamento psiquiátrico, psicológico e ocupacional duas vezes por semana no HD.

A entrevista foi realizada cinco meses após a entrada de Sofia no GRATA. No momento da entrevista, ela apresentava peso de $44,1 \mathrm{~kg}$ e IMC $=14,9 \mathrm{~kg} / \mathrm{m}^{2}$, ainda muito abaixo do esperado. Referia ter aversão a arroz e feijão, mas havia incluído frutas na alimentação. Sentia falta da companhia da mãe, que havia voltado a trabalhar, mas se sentia mais alegre, disposta e tranquila. Referiu melhora nos pensamentos obsessivos de emagrecimento. Negou vômitos e uso de laxantes na época em que a entrevista foi realizada.

Sofia relatou que, desde a instalação do TA, tem "vivido em uma montanha russa", ou seja, tem fases boas e ruins. Nas fases boas, a participante sente-se bem e se permite comer vários tipos de alimento, em pequenas quantidades. Em contrapartida, quando está atravessando uma fase ruim, sente culpa por ingerir determinados alimentos e vivencia conflitos referentes à necessidade de comer para sobreviver.

Sofia referiu que, antes mesmo da instalação do TA, já era uma pessoa fechada e isolada, que gostava mais de "ficar em um canto". No entanto, com o desenvolvimento do transtorno, esse isolamento foi intensificado. 
[...] Eu não tenho mais vida social quase, assim... Eu só vou a lugares onde eu conheço, casa de uma amiga, quando é de alguém assim, mas fora isso é muito difícil... eu sair...

Além disso, a participante também relata que sempre foi magra, "desnutrida" e sempre comeu pouco. Na adolescência, tinha desejo de ganhar peso, pois não gostava de ouvir as pessoas dizerem que estava magra demais. Relatou que a questão do peso estava sempre presente nas conversas familiares e que a mãe cobrava muito de suas irmãs que elas se alimentassem de forma saudável, pois elas estavam sempre acima do peso. Além disso, a mãe sempre fez "dietas malucas". A preocupação em perder peso, segundo o discurso da participante na entrevista, surgiu aos 25 anos de idade, quando ela acreditava que seu metabolismo iria diminuir e que ela iria engordar, além do medo que ela tinha de se tornar "gordinha" como a mãe e as irmãs.

Além do isolamento, a instalação do TA também culminou em um quadro de depressão, acarretando muitos medos. Sofia relatou que sentia muito medo, mas não sabia nomear o motivo. Sentia vontade de "ir sumindo aos pouquinhos", e sentia uma satisfação ao perceber que estava conseguindo controlar a necessidade de se alimentar. Alguns desses sentimentos ainda permanecem na vida de Sofia e dificultam seu engajamento no tratamento, tanto no HD quanto no GRATA, uma vez que há conteúdos sobre os quais ela não quer pensar. Além disso, o prazer de conseguir controlar a alimentação se mostrou como um fator mantenedor do TA.

É muito complicado a gente ter que olhar assim pra gente e ter que resolver algumas coisas que a gente não quer. (...) Eu também não aceitava muito bem a minha doença, e ainda não aceito, não posso falar que eu acordo todo dia pensando que hoje não quero ser assim, eu não posso falar isso agora, porque teve épocas que eu chegava no meu psiquiatra e falava que eu achava que era melhor eu ficar doente, que a doença era a única coisa que eu tinha, e era a única coisa que eu controlava, a única coisa que eu já conhecia.

A dificuldade de lidar com algumas questões cruciais comprometia a participação de Sofia no tratamento, principalmente no que tange aos grupos de apoio oferecidos pelo GRATA e pelo HD, cujo caráter de semi-internação também incluía vários grupos de apoio. A participante relatou que é muito difícil se deparar, nos grupos, com pessoas que têm o mesmo problema que ela e que fazem tratamento havia muitos anos. Essa troca de 
experiências, no entendimento da participante, comprometia sua perspectiva de melhora. Em contrapartida, Sofia reconheceu a importância desses grupos, demonstrando ter consciência de que eles podem fazer bem. Também referiu que se sente acolhida pelos profissionais do GRATA.

A participante expressou a vivência de um "vazio que nunca preenche" e que marca sua vida com sentimentos de solidão e angústia. Referiu que lembrar-se de alguns fatos da infância despertam sentimentos negativos, que se misturam com os sentimentos relacionados ao TA, e que ela "não sabe onde começa um e onde termina o outro". Esses elementos, mencionados pela participante como possíveis causas do TA, englobam: alcoolismo do pai, depressão da mãe e brigas entre o casal, que eram "descontadas" em Sofia por meio de violência física.

A convivência com as outras pessoas foi pontuada como sendo a maior dificuldade que Sofia passou a vivenciar após a ocorrência do TA. Ela confidenciou que, para conviver com outras pessoas, é necessário comer, uma vez que a maioria dos programas que os amigos fazem envolve, de alguma maneira, o contato com a comida. Assim, para evitar o mal-estar decorrente de estar próxima à comida, Sofia relatou que se isolou das pessoas. Antes desse isolamento, ela mantinha alguns amigos do trabalho e da infância, e realizava atividades sociais com eles de vez em quando. Hoje em dia, as pessoas com quem mais convive são seus familiares, incluindo mãe, pai e irmãs, sendo que uma das irmãs é casada e não mora na mesma casa que a participante.

Então eu me isolei bastante. Acho que a parte é que mais machuca, que mais me machucou, que me marca mais é o isolamento mesmo que eu entrei, assim... Apesar de ser uma pessoa mais quieta, mais calada, eu sempre tive amigos, sempre saí bastante, e agora eu sou mais solitária, assim.

Atualmente, Sofia tem atividades de lazer muito solitárias, tais como ler livros, ouvir música e navegar na internet. A única atividade de lazer compartilhada é brincar com o cachorro, já que todos os membros da família gostam disso. Desde a ocorrência do TA, a participante parou de realizar atividades de lazer e passou a "viver em função do tratamento", ou seja, passa muito tempo no hospital e o resto do tempo permanece em casa. 
Apesar de relatar que os familiares são as únicas pessoas com quem tem contato, e que são sua principal fonte de apoio, Sofia também considerou que não havia um relacionamento afetivo positivo entre eles. A participante relatou que, apesar de fazerem parte de uma família, os membros não interagem entre si e o contato entre eles é muito escasso. Não há realização de atividades compartilhadas, exceto brincar com o cachorro. Essa ausência de proximidade entre os membros da família faz com que Sofia sinta falta de "colo", de pais mais presentes e de relacionamentos familiares que não sejam permeados por brigas e discussões.

O engajamento da família no tratamento surgiu no discurso de Sofia como uma das mudanças que ela gostaria que acontecessem em sua vida. A participante considerou que, desde quando os pais começaram a fazer terapia e a participar dos grupos de apoio do GRATA, houve uma melhora na compreensão que eles possuem do transtorno e, consequentemente, na forma como eles lidam com as dificuldades da filha.

A rede social significativa de Sofia é composta por 10 membros, distribuídos entre os quadrantes Família e Amigos, e na parte do GRATA. Pode-se considerar que a rede social apresenta tamanho médio e baixa composição. No quadrante da Família, foram incluídos três membros das Relações Íntimas (mãe, pai e irmã do meio), nas Relações Sociais consta apenas a irmã mais nova e nos Conhecidos foram inseridas a avó, uma tia e uma prima. No quadrante dos Amigos foram inseridos: um amigo, que mora em outro Estado, com quem a participante mantém contato via internet e telefone, e uma amiga, que a participante conheceu na época em que ainda trabalhava. Por fim, na parte do GRATA, foi inserida a nutricionista, com quem Sofia descreveu ter uma Relação Íntima. Todos os membros da rede social da participante têm contato entre si, denotando alta densidade. 


\section{Participante 8-Amanda}

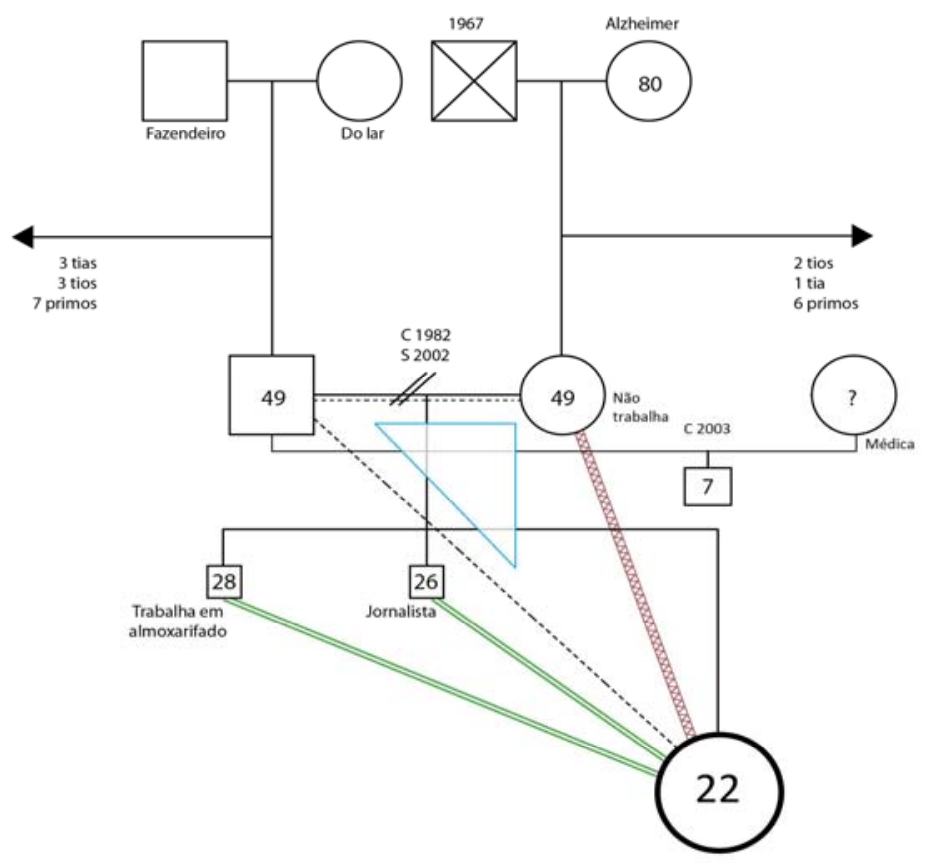

Figura 16. Genograma de Amanda

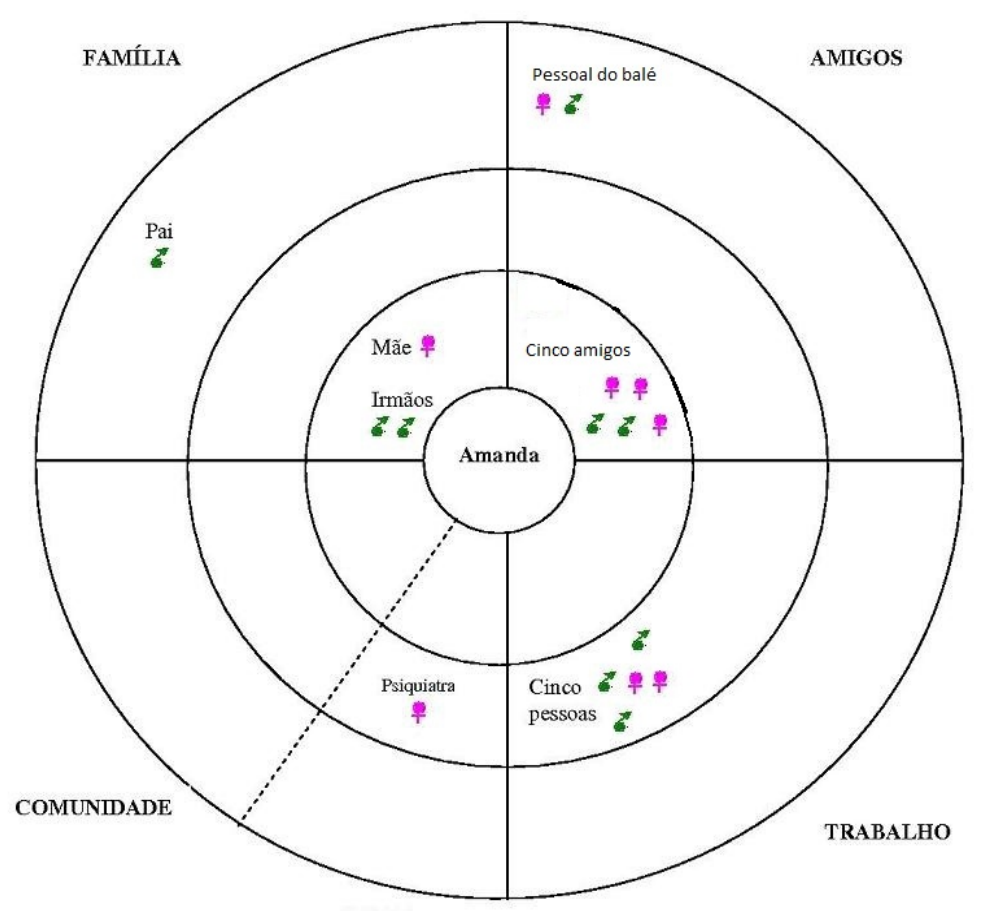

Figura 17. Mapa de Redes de Amanda 
O início do tratamento de Amanda no GRATA começou no ano de 2007, após uma internação decorrente de um quadro de desnutrição e fraqueza muscular progressiva. Apresentava dificuldade para caminhar e havia tido dois episódios de síncope. Segundo os dados do prontuário hospitalar, a participante relatava que, no ano anterior, havia começado a apresentar uma preocupação excessiva com a imagem corporal, associada com a distorção dessa imagem. Desde então, começou a restringir a alimentação, a provocar vômitos e a fazer uso de laxantes e diuréticos - aproximadamente oito comprimidos de cada tipo por dia. Em termos clínicos, Amanda apresentava diagnóstico de $A N$ do tipo purgativo, pesava $47,6 \mathrm{~kg}$, tinha $1,66 \mathrm{~m}$ de altura e $\mathrm{IMC}=17,3 \mathrm{~kg} / \mathrm{m}^{2}$, adequado aos critérios diagnósticos para o quadro de AN, segundo o DSM-IV-TR ${ }^{\mathrm{TM}}$ (Associação Americana de Psiquiatria, 2002).

A entrevista foi realizada em um momento em que Amanda não estava seguindo o tratamento de forma adequada, apresentando pouca assiduidade e recusa a participar dos grupos de apoio. Segundo os dados do prontuário, a participante referia estar muito nervosa, trabalhando muito e apresentava dificuldades no relacionamento com um companheiro de trabalho. Apresentava também uma diminuição na quantidade de alimentos ingeridos, e relacionava essa diminuição ao nervoso que estava vivenciando. Havia parado de ministrar os medicamentos psiquiátricos há seis meses e não fazia terapia. Amanda tinha 22 anos de idade, o peso era de 50,8kg, a altura permanecia a mesma e o IMC $=18,4 \mathrm{~kg} / \mathrm{m}^{2}$, considerado dentro da faixa de normalidade.

A entrevista foi Amanda foi realizada no local de trabalho da participante - um clube no qual ela trabalhava como secretária -, a pedido da mesma, que não desejava permanecer na instituição hospitalar por mais tempo além do necessário para participar dos grupos e realizar os atendimentos individuais. Dessa forma, a entrevista foi realizada individualmente, em uma sala vazia do local de trabalho. A participante se demonstrou muito impaciente e nada solícita, fornecendo respostas curtas e pouco aprofundadas.

Amanda iniciou a entrevista relatando que, atualmente, não sofre mais dificuldades com a alimentação, e que "já meio que tá superado isso". A participante considera que "mudou o foco", ou seja, passou a se preocupar mais com o trabalho e menos com a comida, e com isso conseguiu se desligar do TA. No entanto, em momentos de nervoso ou irritação, Amanda volta a restringir a alimentação. 
Toda vez que eu fico ou tipo nervosa, ou irritada, ou não sei, qualquer outra coisa assim, eu ataco na comida. E eu acho que eu vou ter que me policiar nisso para não ir parando de comer a cada emoção diferente que eu tiver...

Segundo o discurso da participante, ela não percebeu a ocorrência do TA até o dia em que a psicóloga da escola de dança, na qual Amanda fazia aulas de balé, a aconselhou a procurar ajuda psicológica por "não estar bem". Amanda relatou que a psicóloga fez essa sugestão depois de ter observado a participante em uma viagem da escola, na qual ela não se alimentou durante dois dias inteiros.

Amanda teve duas internações: uma com duração de sete dias, e outra mais prolongada, de dois meses, com alta licença aos finais de semana. Na segunda internação, a participante apresentou uma tentativa de suicídio, jogando-se da escada da instituição hospitalar. Quando questionada a respeito dos motivos que a levaram a se jogar, Amanda relata que não se lembra se estava nervosa, ou se tinha comido.

Eu não me lembro muito bem por quê que foi... Sei que eu estava irritada.

Após a tentativa de suicídio, a participante relata que passou a pensar de forma diferente, a perceber que não podia viver em função da dificuldade com a alimentação e do TA.

Então, aí eu fui vendo que tipo, eu precisava de outras coisas, né? Não podia ficar só vivendo em função de hospital, era muito nova. Tinha que, né, viver minha vida, procurar outras coisas diferentes... E aí foi indo... Acho que eu fui mudando, foi passando...

No entanto, Amanda tem consciência da necessidade de continuidade do cuidado com o TA. Apesar de acreditar que "melhora, tem cura", a participante também relata saber da importância de "ter que se policiar pro resto da vida".

No que concerne ao tratamento no GRATA, Amanda demonstrou ter bastante dificuldade com os grupos de apoio que, segundo o discurso na entrevista, "é insuportável".

Ai, porque eu não gosto. Ai gente, não sou psicóloga pra ficar ouvindo os problemas dos outros, já tenho os meus... Não gosto. 
Além de não gostar de participar dos grupos de apoio, Amanda também relata que "nenhuma parte [do tratamento] é legal", uma vez que as pessoas procuram o tratamento para "curar uma doença". A participante considera que receber alta é a única parte boa do tratamento. No entanto, sente-se acolhida pelos profissionais do GRATA, principalmente pela psiquiatra.

A principal dificuldade que Amanda vivenciou durante a ocorrência do TA foi sair com os amigos, principalmente sair para comer. Segundo o discurso na entrevista, as pessoas costumavam reparar que Amanda não comia e faziam críticas a respeito de sua magreza. A participante relata que isso era incômodo pelo fato de que ela não acreditava que estava magra e não queria ser repreendida por não comer. Em função dessa dificuldade, passou a não sair mais de casa e se afastou da maioria de seus amigos. Atualmente, a participante costuma sair bastante com um grupo de sete amigos, constituído por seus dois irmãos, as namoradas dos irmãos e mais três amigos, que são muito próximos.

Pra todos os lugares, saio muito, nossa... Tem, tipo, é... Eu tenho um grupo de amigos e tal, que nós somos em oito, então, tipo assim, é nós oito. Então, a gente tá junto praticamente todos os dias [...] Ah, não tem lugar específico. A gente vai pra barzinho, a gente vai pra boate, a gente vai pra casa dos amigos, a gente vai pra casa dos amigos dos amigos, a gente vai pra casa do namorado dos amigos (risos). Pra todo lugar a gente vai...

A participante relatou ter uma "ótima" relação com seus irmãos e sua mãe, que a ajudaram bastante na época mais difícil do TA, demonstrando preocupação, acompanhandoa no tratamento e buscando alternativas para lidar com as dificuldades alimentares que Amanda apresentava. A relação com o pai, no entanto, parece ser muito distante. Amanda relata que seus pais são separados há oito anos, e que não possui muito contato com o pai. Durante as internações, ele frequentava o hospital e fazia visitas à filha no período da mãe, para não se encontrar com a mãe, que fazia as visitas no período da tarde. No entanto, após poucos dias de internação, o pai parou de visitar a filha. Quando questionada a respeito da relação com o pai, Amanda relata que gostaria que fosse diferente, mas "não encana com isso".

A configuração do Genograma de Amanda evidenciou a existência de uma triangulação entre ela e seus pais, caracterizada por uma relação fundida e conflitual entre mãe e filha, e distante da figura paterna. Tal arranjo familiar parece ter surgido a partir da 
necessidade de encobrir a distância física e emocional que existia entre os pais, uma vez que a fusão entre mãe e filha impossibilitava a entrada de um terceiro na relação, ainda que esse tipo de relacionamento implicasse na ocorrência de vários conflitos entre a dupla.

No que concerne às atividades de lazer, a participante relata que, além de sair com os amigos, voltou a fazer aulas de balé, que havia parado em função das complicações clínicas decorrentes do quadro de AN. Amanda possui relação social com as pessoas da escola de balé, assim como do local trabalho.

A rede social significativa de Amanda é formada por aproximadamente 17 pessoas, configurando uma rede de tamanho amplo. Os membros são bem divididos entre os quatro quadrantes do Mapa de Rede, indicando que as possíveis fontes de ajuda não se encontram centralizadas. Há aproximadamente sete pessoas no quadrante dos Amigos, cinco no quadrante do Trabalho, quatro no quadrante da Família e a psiquiatra do GRATA na parte do serviço de saúde. A maioria dos membros da rede possui contato entre si e proximidade geográfica, apontando para uma alta densidade e baixa dispersão da rede. 


\section{Participante 9 - Juliana}

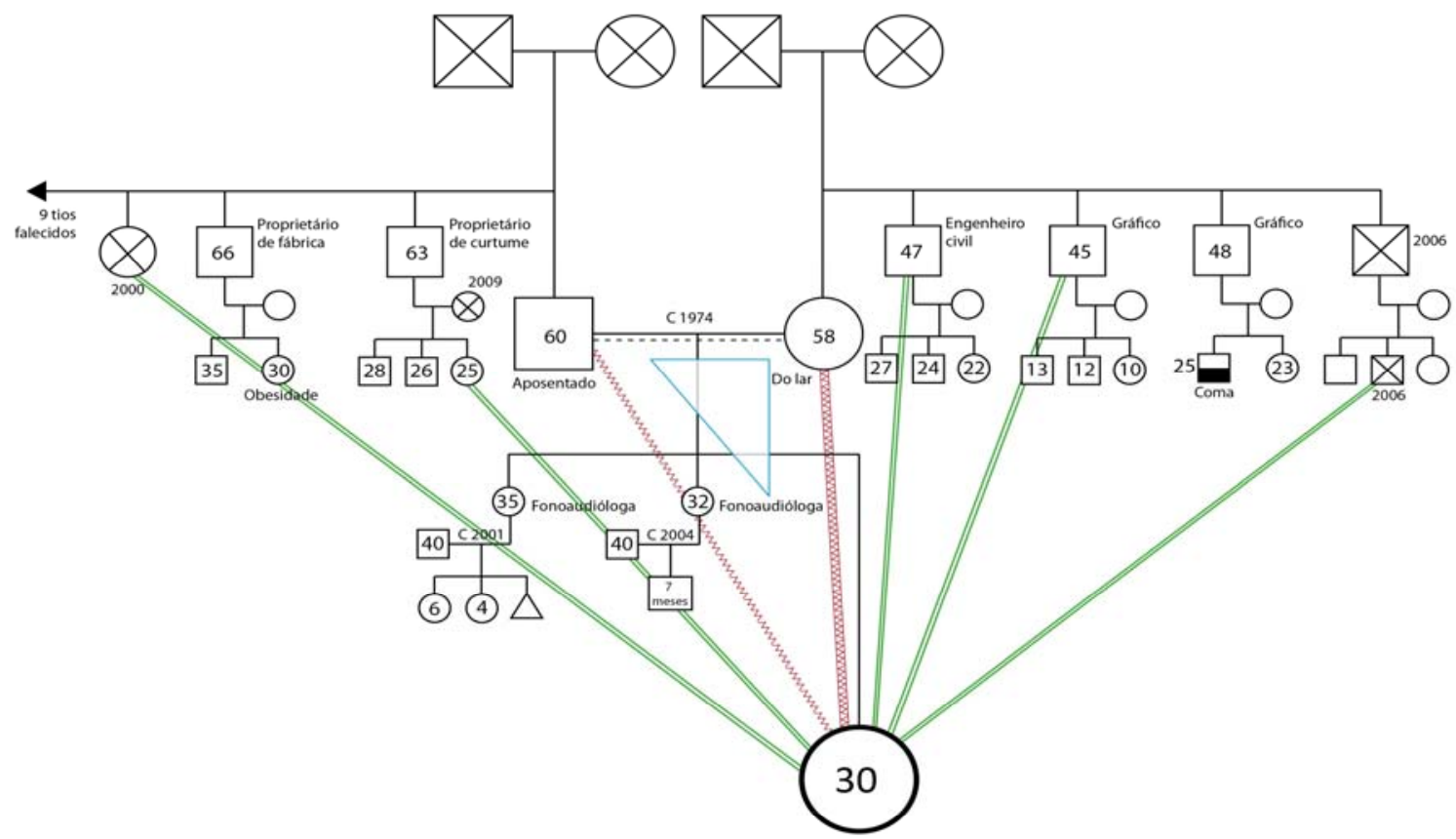

Figura 18. Genograma de Juliana

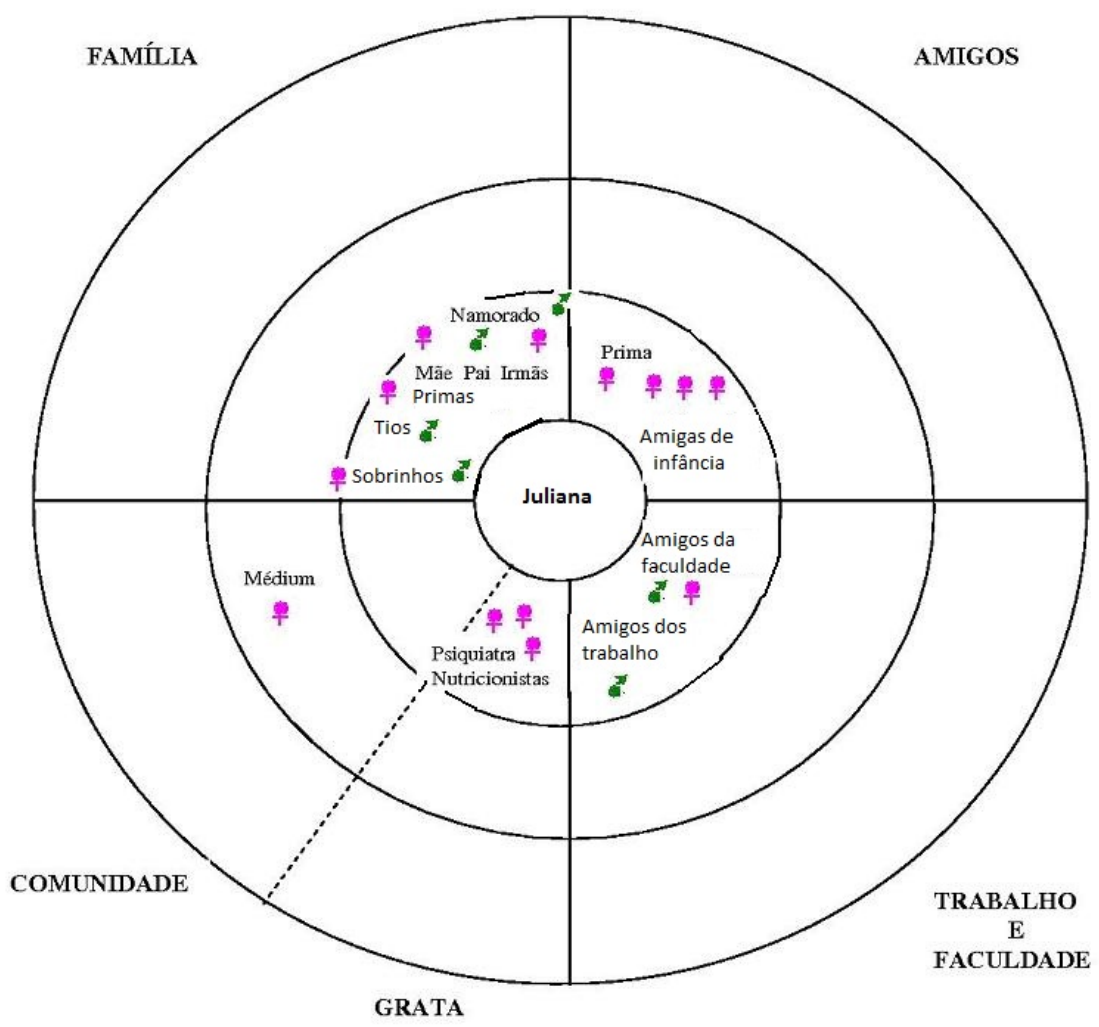

Figura 19. Mapa de Redes de Juliana 
Juliana iniciou o tratamento no GRATA no ano de 1997, quando tinha 16 anos de idade. Pesava 56,8kg, tinha $1,67 \mathrm{~m}$ de altura e $I M C=20,4 \mathrm{~kg} / \mathrm{m}^{2}$, considerado dentro dos padrões normais. A participante apresentava quadro de AN do tipo purgativo, que começou a surgir após um ganho ponderal de $12 \mathrm{~kg}$ em 30 dias, decorrente de uma cirurgia de apendicite. Frente aos comentários dos pais a respeito do ganho de peso, Juliana relatou que decidiu iniciar a restrição alimentar e a realização de atividades físicas intensas, levando a uma perda de $20 \mathrm{~kg}$ em três meses. Um ano após a cirurgia, a participante relatou uma mudança no quadro psicopatológico, que passou a ser caracterizado por alimentação excessiva e vômitos espontâneos. Após alguns meses, a participante começou a provocar os vômitos com a ingestão excessiva de água.

Segundo os dados do prontuário hospitalar, na época da entrevista, Juliana referia melhora na alimentação, pois estava realizando todas as refeições diariamente, apresentando compulsão alimentar apenas no período noturno, quando consumia alimentos em maior quantidade e, em seguida, induzia vômito. No entanto, havia reduzido o número de vômitos, conseguindo passar até três dias sem induzi-los. A participante apresentava peso de $53,3 \mathrm{~kg}, 1,67 \mathrm{~m}$ de altura e IMC $=19,1 \mathrm{~kg} / \mathrm{m}^{2}$, ainda considerado dentro dos padrões de normalidade. O diagnóstico de AN do tipo purgativo se manteve, e foi acrescentado o transtorno de personalidade borderline.

Segundo o discurso da participante na entrevista, esta se considera muito melhor do que já esteve, tanto em termos alimentares quanto emocionais. Relata que ainda "tem crises e muita dificuldade com a alimentação", mas que teve "uma melhora de70\% de quando começou o tratamento". Juliana considera que vivenciou "mudanças internas" e, atualmente, é "outra pessoa, outra mulher". Quando questionada a respeito da forma como era antes, a participante relata que era retraída, não se valorizava, tinha a autoestima muito baixa e apresentava perfeccionismo significativo, que resultava em intensas cobranças autodirigidas. Caracterizavase como "totalmente infantilizada", ou seja, "brigava, xingava e esperneava muito".

Eu era... Uma pessoa... Totalmente sem autoestima... Eu era retraída, não me valorizava nem um pouco, o meu modo de vestir, o meu modo de pensar, o meu modo de falar... Eu era totalmente infantilizada (...).Eu brigo, eu xingo, eu... Esperneio, igual uma criança. Igual uma criança, e a minha vida era assim... Pra você ter uma noção quando eu fazia faculdade, eu... Eu não tinha muitos amigos, entendeu? O meu... A minha atitude, o meu jeito de ser era assim: "Ninguém gosta de mim, eu sou burra, gorda, feia". Hoje eu sou completamente diferente. 
No entanto, Juliana relata que vivenciou uma situação bastante estressante, que fez com que sua vida "mudasse completamente". Na época da entrevista, a participante namorava há 10 anos, mas conta que passou dois anos solteira, após uma traição do namorado. Juliana confidencia que o namorado a trocou por outra mulher, para quem contava a respeito de seu TA, atribuindo ao quadro a necessidade de manter o namoro. A participante relata que, desde então, com o auxílio da terapia, passou a valorizar-se mais, a se "aceitar como mulher, não mais como criança".

Juliana considera que o TA consiste na tentativa de manter um corpo infantilizado para evitar os olhares e os desejos masculinos. Nesse sentido, ela relata que se retraía, se escondia, não penteava os cabelos e não possuía vaidade. Porém, após a traição do namorado, parecem ter acontecido mudanças na autoimagem e autoestima de Juliana. Tais mudanças também foram relacionadas com a forma como a participante passou a lidar com a alimentação: em momentos de maior gravidade do TA, ela "descontava suas frustrações e seus abalos emocionais na alimentação", fazendo com que a comida não exercesse a função de suprir uma necessidade. Essa forma de encarar o alimento foi sendo modificada com o tempo, a partir de uma "mudança interna".

A participante tem a crença de que o TA se origina em traumas vivenciados pelas pessoas, principalmente aqueles de cunho sexual. Filha de pais religiosos, cresceu em um ambiente no qual a questão da sexualidade era um "tabu" e o sexo em si, assim como qualquer relacionamento entre homens e mulheres, era considerado "uma coisa muito suja, muito pesada, muito feia". A participante conta que sofreu muita repressão na infância, e acredita que essa seja uma das causa do quadro psicopatológico que apresenta. Além disso, ter sido chamada de "gordinha" pelo pai durante a infância também parece estar relacionado com a precipitação do TA.

E eu me lembro que quando eu tava com dez anos mais ou menos ele falou que eu tava gordinha... Que aí ele falou assim: "Você tá gordinha, não sei o que, não sei o que, não sei o que, você quando ficar grande você não vai arrumar namorado, vai fica igual a F.", F. era uma amiga da minha irmã que era gordinha e não arrumava namorado porque era gordinha... Depois disso eu parei de comer... Entendeu, eu fui... Aí eu comecei a fazer regime, aí eu fui emagrecendo... Quanto mais eu emagrecia, mais eu queria emagrecer. 
No que diz respeito ao relacionamento com a família, foi relatada a existência de inúmeros conflitos, principalmente com o pai. A participante confidencia que evitava permanecer perto dele, sentia-se irritada com sua voz e não conseguia estabelecer uma conversa. Costumava desafiar as ordens do pai e brigar constantemente. Com a mãe, os conflitos eram menos intensos, mas também muito frequentes. Entretanto, ambos os pais foram considerados como a principal fonte de apoio de Juliana.

A configuração do Genograma evidenciou que existia uma triangulação entre a participante e seus pais, sendo que a relação com a mãe era fundida e conflitual, e distante com o pai. Uma vez que a relação do casal parental era marcada por distância emocional, a triangulação parece ter a função de ocultar as dificuldades decorrentes dessa distância, focando a atenção dos pais no TA da filha e fazendo com que mãe e filha se envolvessem em uma relação de fusão, que impossibilitava a entrada de um terceiro.

O GRATA foi considerado como importante fonte de apoio para Juliana, que encontrou nos profissionais um espaço privilegiado para compartilhar suas emoções e angústias e, assim, realizar mudanças significativas em suas atitudes e formas de pensar. A participante atribuiu ao serviço não apenas a melhora do quadro, mas também a melhora nas relações familiares, que passaram a ser mais saudáveis e respeitosas.

No que concerne às redes de amizade, Juliana relata que sempre teve dificuldade de se relacionar com pessoas, uma vez que vivia em função da alimentação e dos rituais purgativos, que impediam que a participante realizasse atividades de lazer compartilhadas com amigos.

O transtorno alimentar ele te bloqueia você conviver com as pessoas. (...) Só que antigamente eu não podia, por exemplo, sair pra ir numa viagem porque eu ia comer $e$ ia vomitar $e$ as pessoas iam perceber, $e$ isso me envergonhava muito... Mas eu não ia, entendeu? Não era em qualquer festa que eu ia, não era em qualquer lugar que eu ia, então você acaba que... Que... É... Afastando as pessoas.

Atualmente, a participante não sente que o TA permeia todos os aspectos de sua vida, o que facilita a interação com outras pessoas. Sua rede social engloba 13 amigos de infância, colegas de trabalho e da faculdade. Além disso, Juliana relata que realiza atividades de lazer, tais como: ir ao shopping, bares e festas. Essas atividades são realizadas com a companhia de amigas, uma vez que a participante possui um relacionamento bastante 
conturbado com o namorado, que não costuma acompanha-la nas atividades. Juliana descreve seu namoro como: "É um relacionamento assim, aos trancos e barrancos". Caracteriza o namorado como "muito ciumento e agressivo".

A rede social significativa de Juliana é configurada por aproximadamente 30 membros, caracterizando uma rede ampla. Os membros foram incluídos apenas nas Relações Íntimas - exceto pela médium da igreja que a participante frequenta, que foi incluída nas Relações Sociais do quadrante da Comunidade. Todos moram perto uns dos outros e possuem contato entre si, caracterizando uma rede com alta densidade e baixa dispersão. 


\section{Participante 10 - Marina}

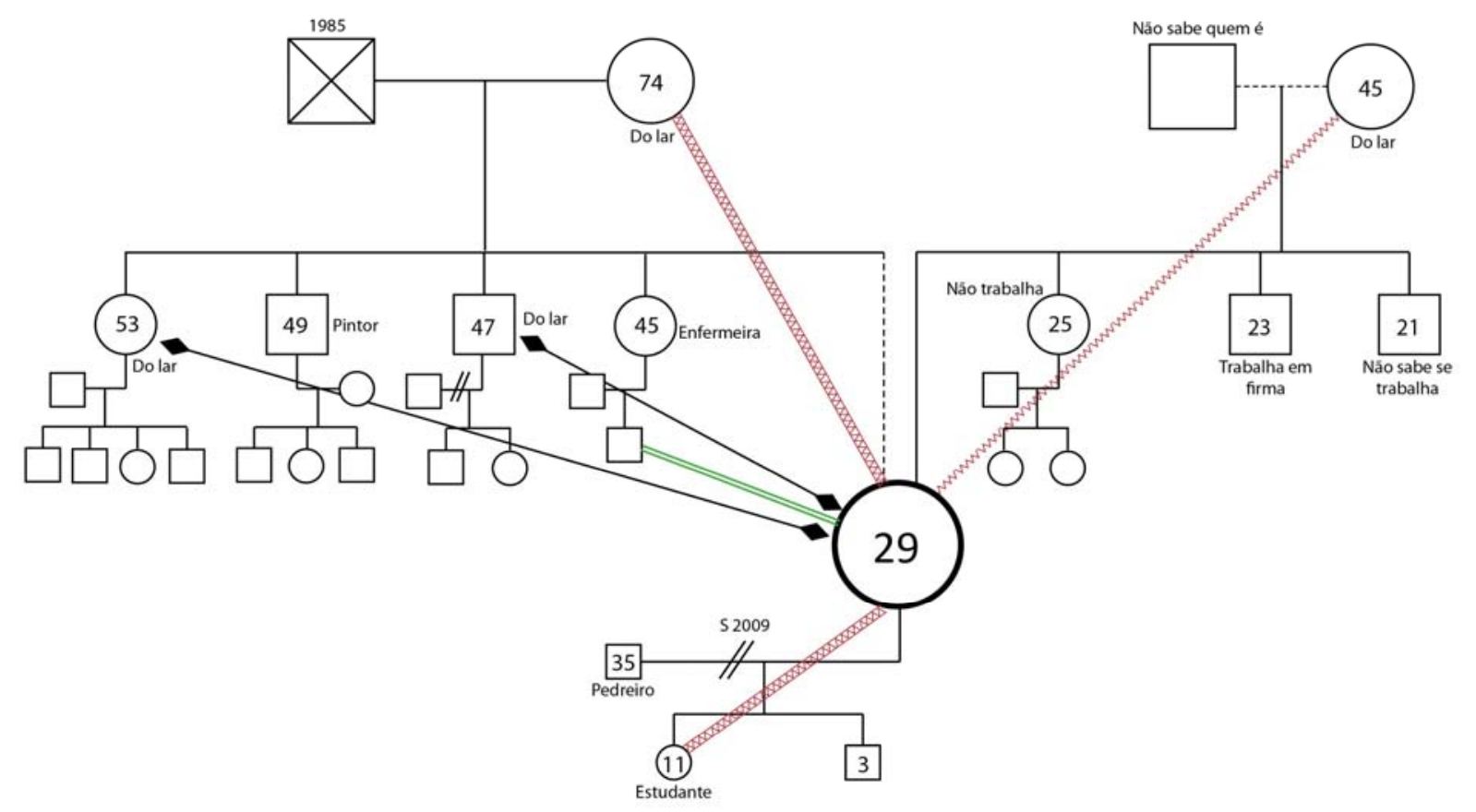

Figura 20. Genograma de Marina

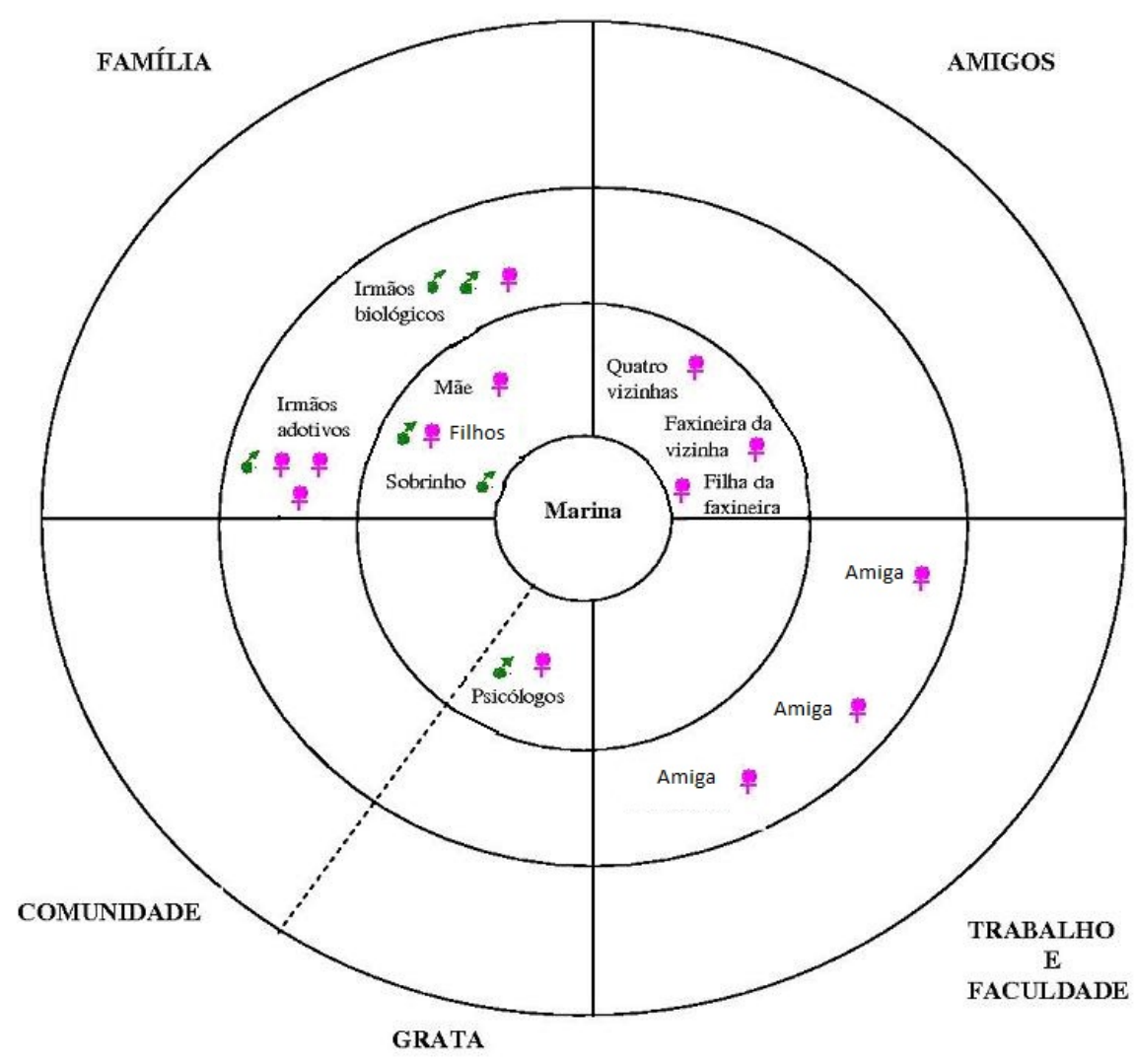

Figura 21. Mapa de Redes de Marina 
Marina iniciou o tratamento no GRATA no ano de 2006, com 26 anos de idade, relatando que provocava vômitos e restringia a alimentação desde o ano de 2004, quando pesava $75 \mathrm{~kg}$. A participante havia ganho $15 \mathrm{~kg}$ após o nascimento de sua filha, que estava com sete anos de idade naquela época. Ao procurar o serviço de saúde, Marina apresentava diagnóstico de AN do tipo bulímico, peso de $57,6 \mathrm{~kg}, 1,69 \mathrm{~m}$ de altura e IMC $=20,2 \mathrm{~kg} / \mathrm{m}^{2}$, considerado adequado pelo DSM-IV-TR ${ }^{T M}$ (Associação Americana de Psiquiatria, 2002). Segundo dados do prontuário hospitalar, Marina referia distorção da imagem corporal, que começou após um problema no casamento. Sentia tremores antes e depois das refeições, que diminuíam após os vômitos.

No momento da entrevista, Marina encontrava-se em seguimento no GRATA há quatro anos. Trabalhava como auxiliar em uma instituição e como dama de companhia de uma pessoa idosa. Havia tido mais um filho, que estava com três anos de idade. 0 diagnóstico da participante havia evoluído para um quadro de $\mathrm{BN}$, em comorbidade com transtorno de personalidade borderline. A participante pesava $60,7 \mathrm{~kg}$ e possuía a mesma altura, apresentando $I M C=21,5 \mathrm{~kg} / \mathrm{m}^{2}$, que se adequa aos padrões de normalidade colocados pelo DSM-IV-TR ${ }^{\mathrm{TM}}$. No prontuário hospitalar constava que a participante referia estar se sentindo bem, sem problemas em casa ou no trabalho. Havia se separado do marido, mas este ainda morava na mesma casa com ela e os filhos, apenas dormindo em quartos separados. Apresentava dificuldade para seguir o esquema alimentar sugerido pela nutricionista, e tinha vômitos de uma a duas vezes por dia. Referia sentir-se gorda.

Durante a entrevista, Marina relatou que não apresentava episódios de vômito depois de todas as refeições, apenas quando se sentia nervosa ou quando acontecia algo mobilizador em sua vida, tal como uma decepção. Confidenciou que a decepção inicial que fez com que começasse a se sentir insatisfeita com seu corpo e a realizar os rituais de restrição e purgação alimentar foi uma traição do ex-marido. Este havia tido relação sexual com a prima da participante, que descobriu a traição e passou a apresentar os sintomas de TA.

Eu achei, assim, que eu amava ele demais, eu não queria perder ele, imaginava que pelo fato de ele ter me traído com a minha prima, e minha prima era assim, bem magrinha, eu nunca fui gorda, sempre tive esse corpo, eu pensei assim: "Nossa ele gosta de mulher bem magra, então se eu ficar assim bem magra igual ela, ele nunca vai largar de mim, não vai me abandonar". Então foi onde eu comecei a comer e vomitar, fazer regime, daí eu comecei a tomar um monte de remédio, tomei um monte de chá, foi assim que começou tudo. 
Desde então, Marina considera que o TA "não vai ter cura, não vai ter fim". Relata que não consegue focar o pensamento em nada além da alimentação, do corpo e do peso. Realiza comparações constantes com sua filha de 11 anos, que possui um "corpo lindo. Lindo, lindo, lindo".

Quando ela tá se trocando, tá assim de calcinha e sutiã, eu fico assim, babando. Teve época que assim, eu e ela brigávamos constantemente, até comentei com a psicóloga, ela disse: "Mas não é certo, ela é uma criança, tá se desenvolvendo agora". E ela, pra me provocar ela ficava me insultando: "Olha o meu corpo, você não tem meu corpo" [...] E isso me irrita muito, eu falo: "Calma lá, eu ainda vou chegar lá, ainda vou usar as tuas roupas, aquele vestido que você não tá usando eu vou usar".

Houve uma época de piora dos sintomas do TA, quando a participante ficou internada durante um mês: ela havia parado totalmente de comer e relatava que não tinha mais vontade de viver e queria se matar. Apesar da gravidade dos sintomas relatados nessa época, Marina não consegue atribuir essa piora a algum evento estressante ocorrido em sua vida. Houve também um período de melhora, quando a participante teve seu segundo filho. Passou um ano sem frequentar o GRATA e achou que havia "se curado". No entanto, após uma nova decepção amorosa, Marina voltou a apresentar os sintomas.

Eu acho assim, eu acho que eu fui buscar uma liberdade que eu nunca tive. Eu comecei a namorar meu ex-marido eu tinha dez anos, namorei até os dezessete. Casei, logo já fiquei grávida, dai fui trabalhar, inventei de trabalhar, comecei como garçonete em uma lanchonete. Daí lá você faz novas amizades, conhece gente nova, e acabei me envolvendo com uma pessoa. Daí o que aconteceu, gostei dessa pessoa, tive um envolvimento, me iludi, daí acho que por causa dessa ilusão que eu tive a recaída.

Marina considera que "deu o troco para o marido", apesar de ter sido "iludida" e de sofrer muito pelo homem por quem se apaixonou. O casamento de Marina havia sido muito conturbado, permeado por traições de ambas as partes e por separações curtas. A participante relata que "tinha medo de se separar e não ter condições de criar a filha sozinha", até que passou a acreditar em sua capacidade e decidiu se separar, "ir em busca de sua felicidade".

Desde o início dos sintomas de TA, a participante relata vivenciar muita ansiedade, por querer emagrecer cada vez mais. Também vivencia muitos sentimentos de culpa após a 
alimentação, por acreditar que não deveria ter comido. Esse sentimento desperta os vômitos, que fazem com que Marina "se sinta pior ainda". Em função dessa necessidade de vomitar após as refeições, a participante deixou de realizar atividades de lazer que envolvessem comida, tais como ir a festas e lanchonetes.

Porque tem lugar assim, principalmente lanchonete, que não tem banheiro, alguma coisa assim, aí você fica no desespero... Às vezes eu tinha que levar sacolinha pra vomitar dentro...

Durante a construção do Genograma, Marina contou que era adotada. Conta que com cinco anos de idade a mãe lhe contou sobre a adoção, mas a participante demorou a desejar conhecer sua família biológica. Quando finalmente decidiu conhecer essa família, se decepcionou muito. Relatou que pensava: "Essa é a mulher que me teve?", e que não conseguia olhar para a mãe biológica. Atualmente, a participante mantém contato com seus irmãos biológicos, mas mantém distância da mãe em função de um sentimento de raiva que possui em relação a ela. Quanto ao pai, Marina relatou não saber quem é, e quando questionada a respeito disso, apenas respondeu que nunca se interessou por conhecê-lo. A mãe adotiva foi considerada a principal fonte de apoio de Marina, apesar de considerar que o TA é uma "frescura" da filha e não acompanha-la no tratamento.

No que concerne a amizades, Marina relata ter poucos amigos e nenhuma amiga de verdade, para quem ela "possa chegar e contar tudo". As vizinhas constituem a rede de amizades da participante, mas trata-se de uma relação é conflituosa, na qual as amigas julgam Marina dizendo que o TA é "frescura" e que ela "quer aparecer".

A rede social significativa da participante era composta por 22 pessoas, caracterizando uma rede ampla. Era composta por três amigas do trabalho, quatro vizinhas, a faxineira de uma das vizinhas, a filha dessa faxineira, os quatro irmãos adotivos, os três irmãos biológicos, a mãe adotiva, os dois filhos e um sobrinho. Dois psicólogos do GRATA também foram inseridos como Relações Íntimas no quadrante do serviço de saúde. Nota-se que a maioria dos membros concentrava-se no quadrante da Família. Os membros da rede social de Marina não possuem contato entre si - exceto pelos membros da família - e há distância geográfica entre eles, caracterizando uma rede com baixa densidade e alta dispersão. 


\section{Participante 11 - Estrelinha}

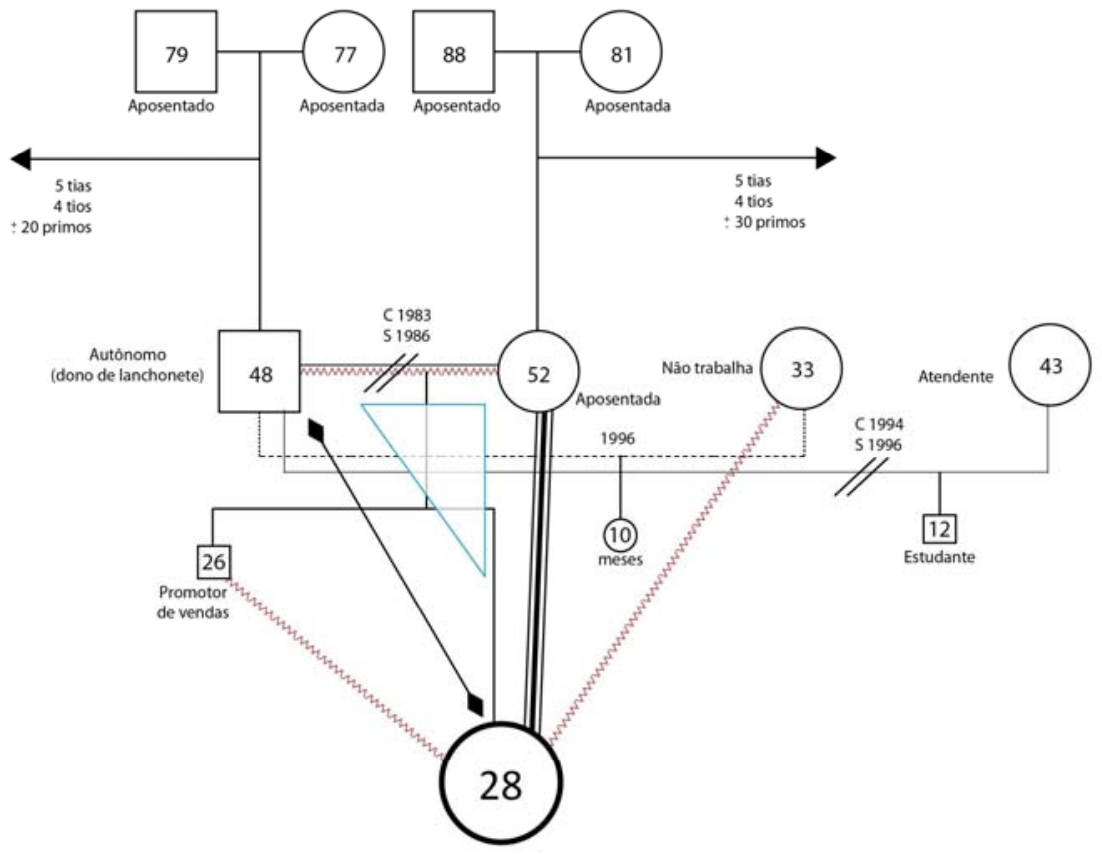

Figura 22. Genograma de Estrelinha

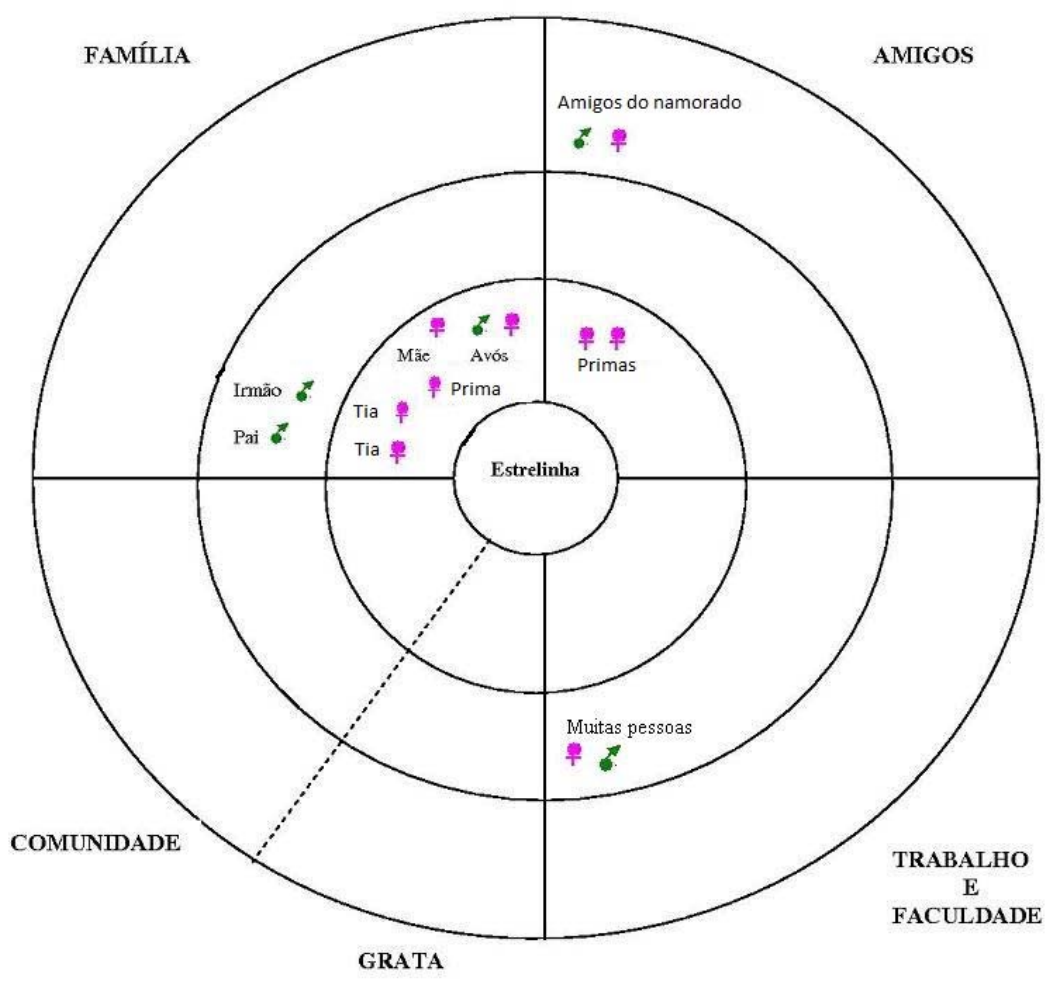

Figura 23. Mapa de Redes de Estrelinha 
A entrevista com Estrelinha foi realizada logo que ela iniciou o tratamento no GRATA. A participante havia sido aconselhada por uma psiquiatra da instituição hospitalar, com quem fazia seguimento, a procurar o GRATA, em função de vômitos espontâneos que ocorriam após a alimentação, os quais não conseguia controlar. No entanto, segundo consta no prontuário hospitalar, Estrelinha não apresentava distorção de imagem corporal ou queixas de insatisfação com o peso e a forma corporal: a participante expressava o desejo de ganhar peso e parar de vomitar.

No que concerne aos dados clínicos, a participante pesava $47 \mathrm{~kg}$, tinha $1,71 \mathrm{~m}$ de altura e $I M C=15,9 \mathrm{~kg} / \mathrm{m}^{2}$. Apresentava o diagnóstico de $\mathrm{AN}$ do tipo purgativo, em comorbidade com transtorno de personalidade borderline.

No momento da entrevista, Estrelinha encontrava-se com os cabelos bastante desordenados, vestida com uma calça da cor verde, uma blusa branca, e chinelos. Falava muito rapidamente sobre vários assuntos que se interligavam, dificultando a compreensão do raciocínio que realizava. A participante iniciou a entrevista dividindo seu TA em dois momentos: o primeiro foi cinco anos antes, quando ela ainda não sabia o que era $\mathrm{AN}$ e $\mathrm{BN}$ e não conseguiu encontrar tratamento na cidade onde morava. A participante conta que havia emagrecido $22 \mathrm{~kg}$ em um mês, e atribui o início dos sintomas ao final de um relacionamento. O segundo momento foi o atual, com o retorno dos sintomas.

A primeira vez que Estrelinha apresentou o TA, ela se sentia muito cansada por trabalhar como promotora de vendas "em dois ou três lugares" e relata que "era a mulher e o homem da casa, porque era ela quem sustentava a casa". Além disso, a participante morava com um homem e estava muito insatisfeita com o relacionamento.

Trabalhava, ele morava em [cidade distante], e vinha de final de semana. Mas chegava final de semana mesmo ele não ficava comigo, ficava com os amigos, ficava na farra dele, e eu fui vendo que aquilo pra mim não era vida, porque eu me matava, chegava final de semana, ele tinha tudo o que queria, de repente ele saía com os amigos dele, voltava na minha casa $22 \mathrm{~h}, 23 \mathrm{~h}$ da noite e apagava.

A participante relata que foi melhorando do TA aos poucos, sozinha. No entanto, cinco anos depois, os sintomas reincidiram, e Estrelinha não consegue atribuir um significado a esse reaparecimento. Relata que se encontrava "na melhor fase, no melhor momento de sua vida. Tinha comprado um carro, estava saindo, se divertindo". 
A participante apresenta muitas contradições ao longo da entrevista, e uma delas diz respeito à ocorrência dos vômitos. Em um primeiro momento, estrelinha relata que os vômitos reapareceram espontaneamente:

Eu acho que foi o final do relacionamento. Mas dessa vez eu tava na melhor fase, no melhor momento da minha vida, tinha comprado meu carro, tava saindo, me divertindo [...] Mas não teve motivo pra voltar, eu comecei a vomitar, vomitar, vomitar, espontaneamente.

No entanto, logo em seguida, a participante relata que começou a provocar os vômitos, mas que, um tempo depois, estes começaram a ocorrer espontaneamente. Em um terceiro momento, Estrelinha relata que provoca os vômitos para "tirar o peso que está parado":

Não, não, não, não provocava, e até hoje eu não provoco. Provoco agora, por exemplo assim, tô tentando, não é fácil, mas tô tentando. Provoco... Eu comecei, dei o primeiro passo que é vomitar, porque agora ele vem espontâneo, por causa que eu tenho refluxo também, e o meu anel do meu estomago é meio dilatado, então isso também ajuda bastante, e ele volta espontâneo. Daí quando aquilo fica parado, aí eu coloco o dedo pra... Tirar todo aquele peso que tá parado.

A rede social familiar de Estrelinha parece ser bastante conturbada: os pais são separados, e o pai teve dois filhos com mulheres diferentes. A mulher com quem ele atualmente possui um relacionamento tem uma relação permeada por brigas e discussões com Estrelinha, que a caracteriza como "sem vergonha", por já "ter aprontado muito". Além da madrasta, Estrelinha também possui relacionamento conturbado com seu pai, seu irmão e seu namorado, que "não entendem seu problema e acham que ela faz graça, que quer chamar a atenção". A mãe foi caracterizada como a melhor amiga e principal fonte de apoio da participante.

Ah, minha relação é de mãe mesmo, minha mãe é minha melhor amiga mesmo, não tem como, é... Se eu tiver que ir em algum lugar eu levo ela mesmo, se tive que ir até pra balada eu levava ela junto comigo, entendeu, nunca fui de deixar minha mãe de lado, nada disso. Sempre, sempre levei ela.

A relação entre os pais de Estrelinha era marcada por brigas frequentes, sendo caracterizada como conflituosa. Essas brigas parecem ter resultado em uma triangulação, na 
qual a mãe se une à filha em uma relação de superenvolvimento, que não deixa espaço para o pai. Nota-se, então, que a triangulação parece ter a função de ocultar os conflitos existentes os pais, que voltam sua atenção para o TA da filha.

A participante demonstra insatisfação com a forma como seu namorado lida com o TA. Conta que gostaria que ele buscasse compreender melhor o transtorno, que tivesse mais paciência com ela e que percebesse que ela realiza esforços para melhorar. No entanto, a insatisfação com o namorado vai além da forma como ele lida com o TA: Estrelinha também relata que, desde o início do namoro, sente-se insatisfeita com as idas do namorado aos bares e com o fato dele "esquecer que tem namorada". Estrelinha relata que o namorado bebe de forma demasiada, o que desperta vários conflitos entre o casal.

Quanto à rede social de amigos, Estrelinha esboça uma diferença entre amigos e colegas, definindo amigo como "aquele que você pode conta a qualquer hora, a qualquer momento (...) amiga é aquela uma, que se precisar ficar dentro de casa com você ela fica", e colega como "aquele que a gente encontra em qualquer lugar que você vai". Considerando essas definições, a participante relata que não tem amigos, e sim colegas, exceto por duas primas que são muito próximas e que a participante caracterizou como amigas.

Estrelinha inseriu em seu Mapa de Redes muitas pessoas que, segundo seu discurso na entrevista, não fornecem apoio significativo em sua vida. Trata-se de amigos de seu namorado, com quem a participante costuma sair aos finais de semana, e pessoas que ela cumprimenta "na rua ou no mercado", que ela conheceu quando trabalhava como promotora de vendas. Dessa forma, a rede social significativa da participante foi composta por 14 membros, considerada uma rede de tamanho amplo. No quadrante dos Amigos, Estrelinha inseriu os amigos de seu namorado, que nomeou de "colegas", e as duas primas mencionadas anteriormente, com quem a participante possui uma relação de amizade e intimidade. A decisão de inserir as primas no quadrante de Amigos foi tomada pela participante. No quadrante de Trabalho, foram inseridas as pessoas que a participante conheceu quando trabalhava, e que hoje em dia cumprimenta quando encontra. 0 quadrante da Família englobou o maior número de membros da rede, indicando uma centralização das fontes de apoio social. Há conexões apenas entre os membros da família, apontando para uma rede com baixa densidade. Por fim, apesar da participante ter relatado sentir-se acolhida no GRATA, não foram inseridos membros do serviço no Mapa de Redes. 


\section{Participante 12 - Ana}

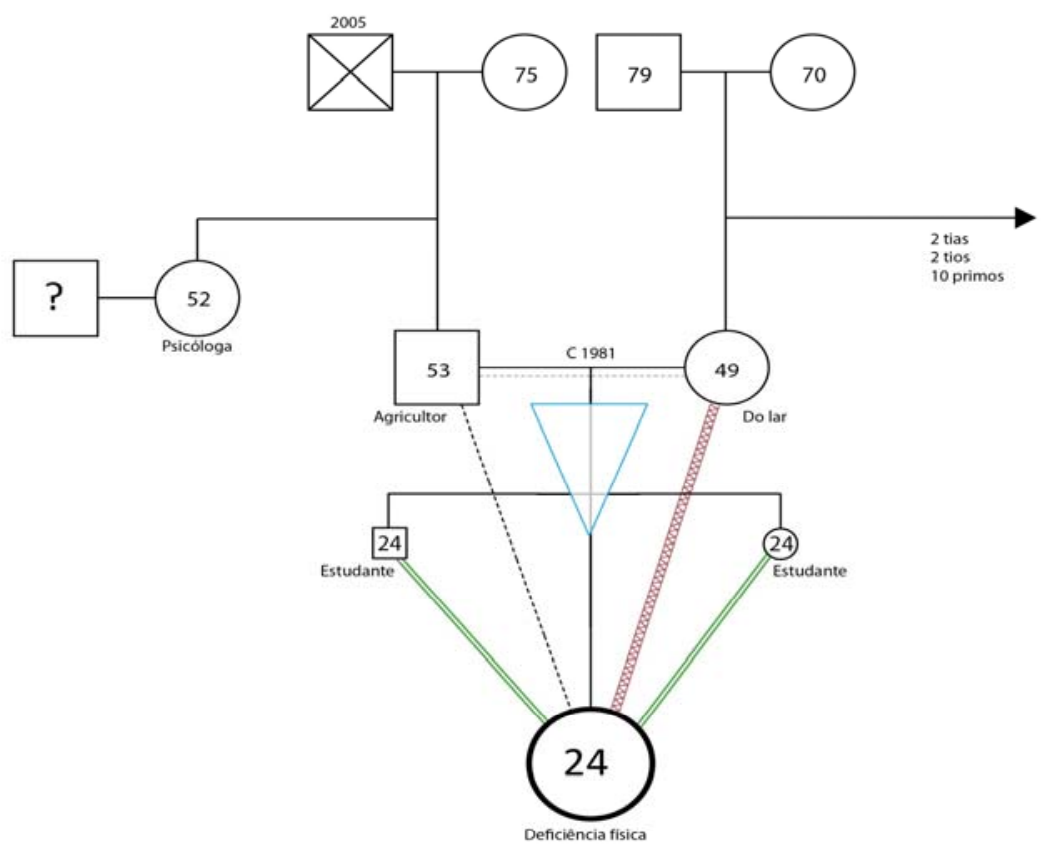

Figura 24. Genograma de Ana

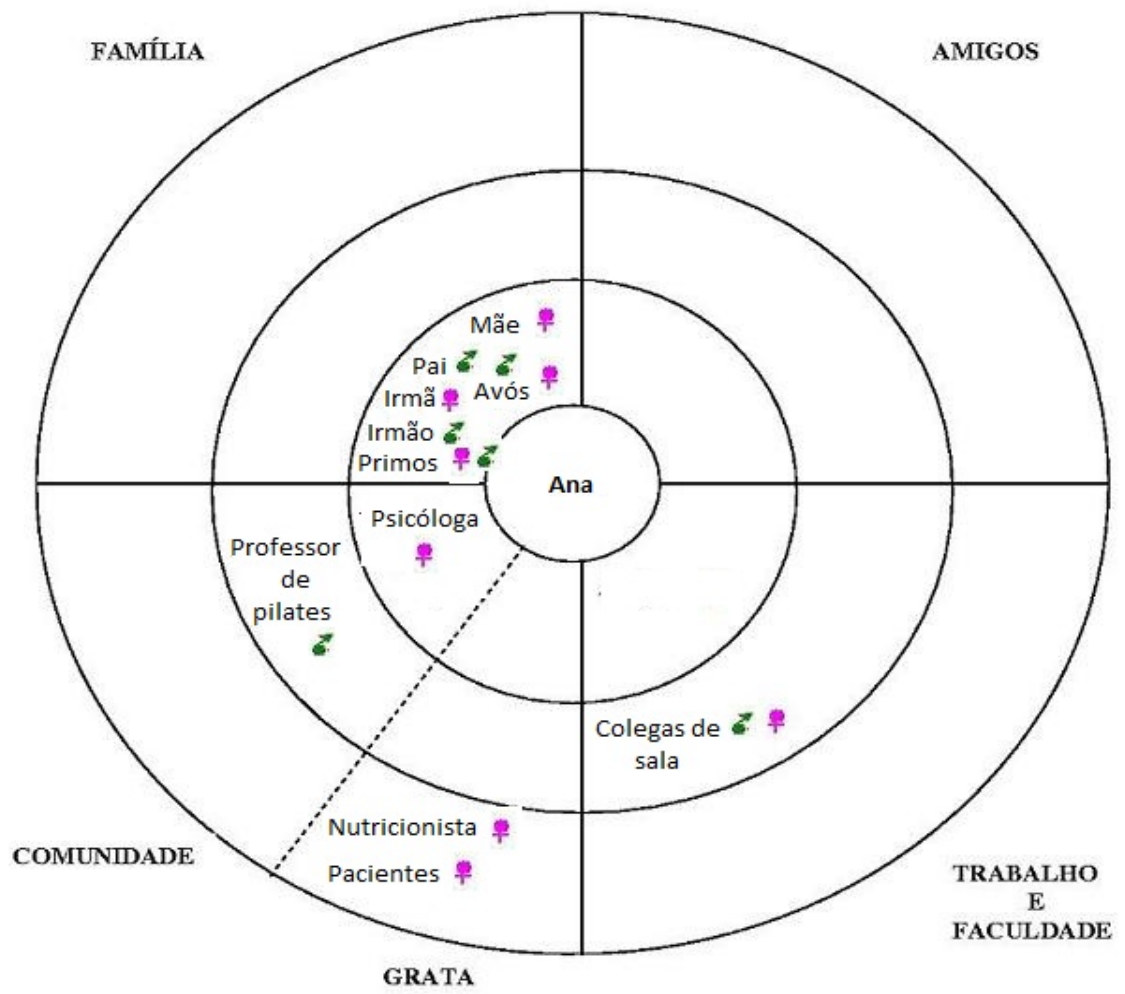

Figura 25. Mapa de Redes de Ana 
Ana iniciou o tratamento no GRATA no ano de 2006, com 19 anos de idade. Apresentava quadro de AN do tipo restritivo, com peso de $35,5 \mathrm{~kg}$, altura de $1,50 \mathrm{~m}$ e IMC = $15,7 \mathrm{~kg} / \mathrm{m}^{2}$, muito abaixo da faixa de normalidade e característico do diagnóstico de $\mathrm{AN}$, segundo o DSM-IV-TR ${ }^{\mathrm{TM}}$ (Associação Americana de Psiquiatria, 2002). A participante havia sido encaminhada por um médico particular de sua cidade, devido a um quadro grave de desnutrição. Apresenta deficiência física em uma das pernas, devido a uma complicação no nascimento.

Após alguns meses de tratamento, o quadro psicopatológico de Ana evoluiu para AN do tipo purgativo, envolvendo a ocorrência de vômitos e uso de laxantes. No momento da entrevista, Ana encontrava-se em processo de alta do tratamento, uma vez que os pensamentos obsessivos acerca da alimentação e da perda de peso, assim como os rituais purgativos e compensatórios, haviam diminuído consideravelmente. A participante havia tido um intervalo de seis meses desde o último atendimento. Tinha 24 anos de idade e cursava o último ano de Psicologia. Pesava $40,6 \mathrm{~kg}$, tinha $1,52 \mathrm{~m}$ de altura e IMC $=17,5 \mathrm{~kg} / \mathrm{m}^{2}$. Apesar de o IMC de Ana ainda ser abaixo de $18,5 \mathrm{~kg} / \mathrm{m}^{2}$ - critério diagnóstico para AN (Associação Americana de Psiquiatria, 2002) -, a participante apresentava estabilidade do peso há um ano, sem restrição ou purgação alimentar.

Considerando-se o processo de alta, a participante inicia seu discurso na entrevista relatando que sua relação com o alimento, atualmente, é boa. Em momentos de maior gravidade do TA, Ana relata que acordava e pensava "Putz, tem que comer?", apontando para uma angústia despertada pela necessidade da alimentação. No entanto, no momento da entrevista, conta que comia "o que tinha vontade, na hora que tinha vontade".

Evidenciou-se que, apesar de estar em processo de alta, Ana não se considera curada. Relata que "nunca vai se considerar curada", pois acredita que o TA faz parte de sua personalidade e que sempre haverá momentos de insatisfação com seu corpo.

$\mathrm{O}$ ato de fazer refeições e sentar-se na mesa com outras pessoas parece ser um dos fatores que mais incomodavam Ana, pois ela acreditava que, por comer quantidades muito pequenas, as pessoas "ficavam olhando indignadas". A participante relatou que, nos momentos de refeição, costumava se sentir pressionada a ingerir alimentos que não desejava, mas que "por causa da sociedade, por causa da família, tinha que comer". O "ter que comer" despertava sentimentos de tristeza em Ana. 
A mãe foi mencionada como a pessoa que mais fazia comentários a respeito dos hábitos alimentares de Ana, principalmente quando a participante comia em grandes quantidades. Esses comentários de sua mãe faziam com que Ana se sentisse arrependida e culpada por ter comido. Entretanto, atualmente, a participante relata relevar tais comentários, sem deixar que causem mal estar. Além disso, relata também uma satisfação ao sentir o sabor dos alimentos que passou muito tempo sem experimentar.

[...] A minha mãe até fala, quando... "Nossa, você ta comendo demais, pàra um pouco de comer". Hoje eu já... Não me importo muito, entendeu? Com o que ela fala, eu olho pra ela e começo a rir, agora se fosse algum tempo atrás, eu ia falar: "Nossa, minha mãe ta falando que eu to comendo demais... Nossa, né...", sabe? Enquanto na verdade não...

No que diz respeito à rede social significativa, Ana mencionou muitos familiares, mas relatou que não tem amigos. A participante descreveu as colegas de faculdade como pessoas com quem possui relações sociais, e com quem convive no contexto universitário. No entanto, não mantém contato com essas colegas durante as férias ou nos finais de semana, e não conversa sobre outros assuntos além daqueles que tratem do curso de Psicologia.

Pra você ter uma idéia, a gente fica férias inteiras sem se ver, não recebo um telefonema [...] Ah, eu concluí que é mais eu que vou atrás do que eles vêm atrás de mim, talvez porque eu não bebo, eu não... Né? Muitas coisas eu às vezes não posso ir porque eu estudo o dobro que eles estudam para poder alcançar eles, ou pra meta da minha faculdade, então pode ser por isso... Que a minha relação é bem complicada, nesse sentido.

Nota-se a existência de um isolamento da participante, que tem preferência por atividades solitárias, tais como estudo e navegar na internet. Quando questionada a respeito de suas atividades de lazer, Ana relata freqüentar o rancho da família, fazer aulas de pilates e psicoterapia.

A família parece configurar a única rede de apoio social de Ana, que afirmou que só incluiria membros da família na parte de Relações Íntimas do Mapa de Redes. No entanto, a participante confidenciou que não há muito diálogo na família imediata, e há uma relação distanciada com o pai.

Ah, talvez eu gostaria de... Porque eu não sei se tem tempo pra isso, né? Porque é a família que eu conheço... Mas eu... Eu não sei se tem tempo ou se tem alguém 
que queria, se é o perfil de alguém, mas eu gostaria de discutir mais sobre as outras coisas, sabe? Sobre o mundo, sobre alguns outros assuntos, saber a opinião deles... E dar a minha, sabe?

Então, meu pai eu não converso muito, a gente só conversa assim, coisas do outro... Coisas de outras pessoas, às vezes ele conta de alguém que eu conheço, assim... Mas ele não conversa muito, não tem diálogo.

É possível perceber que há um desejo, da parte de Ana, de que as relações familiares fossem mais próximas e tivessem mais diálogo. Porém, a participante demonstra acreditar que o pouco diálogo faz parte do perfil de sua família, e que esse perfil não seja passível de mudança. Também foi possível evidenciar a ocorrência de uma triangulação entre Ana e seus pais, caracterizada por uma relação fundida e conflitual entre mãe e filha, mantendo apagada a figura paterna. Tal configuração familiar parece possuir a função de encobrir a relação emocionalmente distante do casal parental.

Apesar dos conflitos com a mãe, que ocorriam em função das críticas a respeito da alimentação de Ana, esta foi considerada a principal fonte de apoio da participante.

A rede social significativa de Ana era constituída por aproximadamente 14 pessoas, considerada rede de tamanho amplo. Havia uma concentração de membros no quadrante da Família ( $n=8$ ), incluindo mãe, pai, avós, primos e irmãos, todos inseridos na parte de Relações Íntimas. Assim, nota-se que se trata de uma rede com baixa dispersão e alta concentração de membros e, consequentemente, do apoio fornecido. Além da família, foram incluídos o professor de pilates, a psicoterapeuta, a nutricionista e as pacientes do GRATA, e alguns colegas da faculdade. Não foram inseridos membros no quadrante dos Amigos.

\subsection{Apresentação dos eixos de análise dos resultados}

Buscando facilitar a visualização dos resultados obtidos no presente estudo, optou-se por dividi-los em dois eixos de análise, articuladas entre si (Orlandi, 2011). O primeiro eixo de análise (Eixo A) diz respeito aos aspectos da vivência do TA, ou seja, engloba os sentimentos e as situações vivenciadas pelas participantes antes e após a ocorrência do quadro psicopatológico, assim como as atribuições de significados relacionados ao início do TA, a percepção as participantes possuem do apoio social recebido e as mudanças desejadas por elas. A seguir encontra-se a Tabela 5, que trata das categorias, subcategorias e elementos de análise do Eixo $\mathrm{A}$ da análise dos resultados. 
Tabela 5. Eixo A - Aspectos da vivência do TA na perspectiva das participantes

Categorias
A1) Circunstâncias anteriores ao TA
- diz respeito ao que as
participantes vivenciavam antes da
instalação do TA.

A1a) Vivências nas redes sociais

A1b) Dinâmica familiar

\author{
Subcategorias
}

Elementos de análise

redes sociais mais amplas ou reduzidas; realização ou ausência de atividades de lazer.

disfuncionalidade das relações familiares; distância emocional entre os membros da família; revolta contra o pai; briga com os filhos.

A2a) Autoestima rebaixada comparações; emagrecimento como
forma de morte; anulação.

A2) Atribuições de significados relacionados ao início do TA fatores que as participantes consideram como precipitantes do quadro.

A2c) Série de eventos estressores casamento; separação conjugal; namoro; repressão emocional; cobranças; dividas familiares; mudança de cidade; excesso de traição do marido; término de trabalho; perdas; apelidos depreciativos; comentário paterno; o "primeiro amor"; separação dos pais.

A3a) Ambivalência entre anseios e necessidades desejo de viver sem o alimento, mas precisar dele para sobreviver; pressão interna.

A3) Vivências e dificuldades decorrentes do TA - fatos, geralmente vinculados a sentimentos negativos, que passaram a ser vivenciados em função da instalação do TA.

\begin{tabular}{l} 
A3b) Incômodo com o julgamento \\
das pessoas \\
\hline $\begin{array}{l}\text { A3c) Viver em função da } \\
\text { alimentação }\end{array}$
\end{tabular}

"perseguida" pelo alimento; luta

A3d) Viver em uma "montanha
russa"
russa"

A3e) Mudanças drásticas na rotina quadro.

compulsão e vômitos como alívio para angústia; sentir-se constante contra o alimento. altos e baixos; ausência do desejo de viver; sentimento de incapacidade. medo de receber críticas; esconder 0

parar de estudar; perder aula; parar de trabalhar; visitar médicos e hospitais constantemente; pensamentos obsessivos constantes; tentativa de suicídio.

A4a) Angústia, dor emocional e ansiedade

A4) Sentimentos vivenciados após a instalação do TA - diz respeito aos sentimentos que as participantes vivenciaram com mais frequência desde a instalação do TA.

\begin{tabular}{l} 
A4b) Solidão, tristeza e vazio \\
\hline $\begin{array}{l}\text { A4c) Vontade de "sumir aos } \\
\text { poucos" }\end{array}$
\end{tabular}

A5) Mudanças desejadas - diz respeito às mudanças que as participantes gostariam que acontecessem em relação TA, ao apoio social recebido e aos relacionamentos familiares. busca de algo; ambivalências; lutas internas; compulsão e purgação alimentar; situações ansiogênicas. alimentação preenchendo vazio; dificuldade nas interações sociais; escassez de relações sociais; isolamento. desejo de morte; isolamento; emagrecimento como forma de morte. mais diálogo, proximidade e carinho nas relações; menos conflitos fraternos; menos críticas; maior participação da família no tratamento; maior união familiar. 
O segundo eixo da análise dos resultados do presente estudo (Eixo B) diz respeito à configuração das redes sociais significativas das participantes. Levando-se em conta os dados oriundos dos Mapas de Redes e dos Genogramas, complementados pelos dados provenientes das entrevistas, o Eixo $B$ trata da participação dos membros das redes sociais em face do enfrentamento do TA das participantes, incluindo aspectos estruturais das redes, os atributos dos vínculos estabelecidos entre as participantes e os membros das redes e os tipos de ajuda recebida desses membros. Além disso, também foram analisados os tipos de relacionamento existentes entre os membros da família, o grau de satisfação das participantes com o apoio recebido pelos familiares e a rede social institucional. Abaixo se encontram as categorias, subcategorias e elementos de análise contidos no Eixo B (Tabela 6).

Tabela 6. Eixo B - Configuração das redes sociais significativas das participantes

\begin{tabular}{|c|c|c|}
\hline Categorias & Subcategorias & Elementos de análise \\
\hline \multirow{5}{*}{$\begin{array}{l}\text { B1) Aspectos estruturais } \\
\text { da rede social } \\
\text { significativa - } \\
\text { características que } \\
\text { expressam a } \\
\text { configuração da rede. }\end{array}$} & B1a) Tamanho da rede & $\begin{array}{l}\text { redes pequenas, médias e grandes; } \\
\text { invisibilidade dos membros. }\end{array}$ \\
\hline & B1b) Composição da rede & $\begin{array}{l}\text { relacionamentos familiares, com } \\
\text { amigos, colegas de trabalho e } \\
\text { estudo e pessoas da comunidade; } \\
\text { mãe como principal fonte de apoio. }\end{array}$ \\
\hline & B1c) Densidade & $\begin{array}{l}\text { membros que se relacionam; } \\
\text { membros que não se relacionam } \\
\text { com outros membros. }\end{array}$ \\
\hline & B1d) Dispersão & $\begin{array}{l}\text { pessoas que moram "perto" ou } \\
\text { "longe"; meios de comunicação } \\
\text { empregados na manutenção do } \\
\text { contato. }\end{array}$ \\
\hline & B1e) Homogeneidade/Heterogeneidade & $\begin{array}{l}\text { gênero, faixa etária, grau de } \\
\text { instrução e vínculo religioso. }\end{array}$ \\
\hline \multirow{7}{*}{$\begin{array}{l}\text { B2) Atributos } \\
\text { dovínculo - aspectos } \\
\text { que engedram o } \\
\text { padrão relacional de } \\
\text { ajuda estabelecido com } \\
\text { os membros } \\
\text { representados na rede } \\
\text { social significativa das } \\
\text { participantes. }\end{array}$} & B2a) História da relação & $\begin{array}{l}\text { como essas pessoas surgiram nas } \\
\text { redes sociais dessas mulheres; } \\
\text { pessoas que surgiram antes e depois } \\
\text { do diagnóstico. }\end{array}$ \\
\hline & B2b) Intensidade do compromisso & $\begin{array}{l}\text { alto, médio e baixo graus de } \\
\text { intimidade - relações íntimas, } \\
\text { sociais e conhecidos. }\end{array}$ \\
\hline & B2c) Frequência de contatos & $\begin{array}{l}\text { alta; média; baixa; escassa; perda } \\
\text { do contato. }\end{array}$ \\
\hline & B2d) Função predominante do vínculo & $\begin{array}{l}\text { frequência de ocorrência de cada } \\
\text { tipo de ajuda; relações entre tipo de } \\
\text { ajuda e aspectos psicossociais dos } \\
\text { membros. }\end{array}$ \\
\hline & B2e) Multidimensionalidade & $\begin{array}{l}\text { conjunto de tipos de ajuda } \\
\text { ofertadas pelos membros de todas } \\
\text { as redes sociais; relação demanda X } \\
\text { ajuda recebida; efetividade da ajuda } \\
\text { recebida; sobrecarga de membros. }\end{array}$ \\
\hline & B2f) Reciprocidade & $\begin{array}{l}\text { tipos de ajuda ofertada aos } \\
\text { membros da rede; contexto no qual } \\
\text { ajudou pessoas de sua rede. }\end{array}$ \\
\hline & B3a) Companhia social & $\begin{array}{l}\text { companhia em casa; na } \\
\text { hospitalização; na realização de } \\
\text { consultas e exames. }\end{array}$ \\
\hline
\end{tabular}




\begin{tabular}{|c|c|c|}
\hline Categorias & Subcategorias & Elementos de análise \\
\hline \multirow{6}{*}{$\begin{array}{l}\text { B3) Funções da rede - } \\
\text { identificou-se uma } \\
\text { pluralidade de formas } \\
\text { de ajuda realizadas } \\
\text { pelos membros das } \\
\text { redes sociais } \\
\text { significativas das } \\
\text { participantes do } \\
\text { estudo, as quais foram } \\
\text { categorizadas em cada } \\
\text { um dos tipos de } \\
\text { funções delineadas por } \\
\text { Sluzki (1997). }\end{array}$} & B3b) Apoio emocional & $\begin{array}{l}\text { aceitação do transtorno; } \\
\text { disponibilidade para escutar; apoio } \\
\text { incondicional; demonstração de } \\
\text { afeto, interesse e preocupação; } \\
\text { cumplicidade; paciência; confiança. }\end{array}$ \\
\hline & B3c) Guia cognitivo e de conselhos & $\begin{array}{l}\text { fornecimento de orientações e } \\
\text { sugestões acerca do modo de vida, } \\
\text { estado de saúde e padrão de } \\
\text { pensamento; recomendações de } \\
\text { cuidado com a saúde; } \\
\text { esclarecimentos e instruções a } \\
\text { respeito do diagnóstico e } \\
\text { tratamento. }\end{array}$ \\
\hline & B3d) Serviços e cuidados & $\begin{array}{l}\text { observações, opiniões e sugestões } \\
\text { sobre seus modos de vida, estado de } \\
\text { saúde e padrão de pensamento; } \\
\text { esclarecimentos e instruções a } \\
\text { respeito do diagnóstico e } \\
\text { tratamento. }\end{array}$ \\
\hline & B3e) Ajuda material e financeira & $\begin{array}{l}\text { oferecimento de ajuda material, } \\
\text { comida, objetos e dinheiro. }\end{array}$ \\
\hline & B3f) Regulação social & $\begin{array}{l}\text { pessoas que estabelecem limites em } \\
\text { relação às condutas das } \\
\text { participantes. }\end{array}$ \\
\hline & B3g) Acesso a novos contatos & $\begin{array}{l}\text { apresentação de amigos e/ou } \\
\text { familiares às participantes. }\end{array}$ \\
\hline \multirow{4}{*}{$\begin{array}{l}\text { B4)Organização das } \\
\text { redes sociais } \\
\text { significativas e } \\
\text { caracterização da } \\
\text { inserção das } \\
\text { participantes - forma } \\
\text { como as redes sociais } \\
\text { estão configuradas no } \\
\text { momento atual da vida } \\
\text { das participantes, e o } \\
\text { modo como estas se } \\
\text { inserem nessas redes. }\end{array}$} & B4a) Redes sociais de amigos & $\begin{array}{l}\text { isolamento; desejo de estar } \\
\text { integrada à rede; não gostar de } \\
\text { estar entre muitas pessoas; muitos } \\
\text { colegas, poucos amigos. }\end{array}$ \\
\hline & B4b) Vida social & $\begin{array}{l}\text { ausência de vida social; poucas ou } \\
\text { nenhuma atividade de lazer; } \\
\text { atividades solitárias; namorado } \\
\text { como companhia social; conflitos } \\
\text { com o namorado. }\end{array}$ \\
\hline & $\begin{array}{l}\text { B4c) Família como rede social mais } \\
\text { significativa }\end{array}$ & $\begin{array}{l}\text { conflitos } X \text { apoio social; relação } \\
\text { permeada por ameaças e } \\
\text { cobranças; triangulação; situações } \\
\text { traumáticas; relações vulneráveis } \\
\text { com o pai e os irmãos; mãe e pai } \\
\text { como principais fontes de apoio; } \\
\text { ausência de apoio. }\end{array}$ \\
\hline & B4d) Apoio familiar percebido & $\begin{array}{l}\text { insatisfação com o apoio recebido } \\
\text { da família; ausência de apoio da } \\
\text { familia extensa; dificuldade dos } \\
\text { familiares em lidar com o TA. }\end{array}$ \\
\hline \multirow{2}{*}{$\begin{array}{l}\text { B5) Rede social } \\
\text { institucional: } \\
\text { Considerações acerca } \\
\text { do tratamento - } \\
\text { opiniões e vivências } \\
\text { relatadas pelas } \\
\text { participantes a respeito } \\
\text { do tratamento do } \\
\text { transtorno. }\end{array}$} & B5a) Dificuldades no tratamento & $\begin{array}{l}\text { participação no grupo de apoio; } \\
\text { aceitar o ganho de peso; falar sobre } \\
\text { o TA; a espera pela alta. }\end{array}$ \\
\hline & B5b) GRATA como fonte de apoio social & $\begin{array}{l}\text { apoio fornecido pelos profissionais; } \\
\text { acolhimento; percepção de } \\
\text { melhoras. }\end{array}$ \\
\hline
\end{tabular}




\section{DISCUSSÃO}

A análise e a discussão dos resultados obtidos no presente estudo teve como norteador os objetivos delimitados, ou seja, investigar o modo como se configuram as redes sociais de mulheres com diagnóstico de TA, assim como o apoio social percebido por elas e suas possíveis implicações para a evolução do quadro psicopatológico. Os resultados serão discutidos à luz da literatura científica especializada e do referencial teórico adotado. A discussão dos dados foi dividida entre os dois eixos ( $A$ e B) já apresentados anteriormente: aspectos da vivência do TA das participantes e a configuração das redes sociais significativas. Durante o processo de análise dos resultados, buscou-se manter em vista a complexidade, a instabilidade e a intersubjetividade que permearam o processo de elaboração do trabalho (Orlandi, 2011).

\subsection{Eixo A - Aspectos da vivência do TA das participantes}

O primeiro eixo de análise do presente estudo englobou aspectos relacionados à vivência do TA pelas participantes, ou seja, incluiu as situações vivenciadas antes da ocorrência do quadro psicopatológico, as atribuições de significados relacionados ao início do TA e as vivências decorrentes da instalação do mesmo. Pretendeu-se, dessa forma, expor as repercussões do TA sobre a vida das participantes. Apesar desses aspectos não estarem diretamente ligados ao objetivo proposto por esta pesquisa, foi possível notar que conteúdos acerca da vivência nas redes sociais apareciam constantemente nos discursos das participantes durante a entrevista. Tais conteúdos abarcavam: aspectos da dinâmica familiar, as amizades (ou a ausência destas), a realização (ou não) de atividades de lazer, entre outros. Por esse motivo, considerou-se que de suma importância a análise dos dados contidos no Eixo A do presente estudo, uma vez que se encontram subjetivamente intrincados com o objetivo inicial desta pesquisa.

Nesse primeiro eixo foram discutidos resultados provenientes das entrevistas com as participantes, buscando-se articular os dados convergentes dos discursos, mas considerando-se também as particularidades de cada caso. 


\subsubsection{Categoria A1 - Circunstâncias anteriores ao TA}

A categoria A1 diz respeito às circunstâncias sociais nas quais as participantes viviam antes da ocorrência do TA, que surgiram nos discursos das participantes durante as entrevistas. Essas circunstâncias envolvem as vivências nas redes sociais e a dinâmica familiar.

\subsubsection{Subcategoria A1a - Vivências nas redes sociais}

A análise da forma como se configuravam as redes sociais das participantes antes da instalação do TA revelou que quatro participantes (Bárbara, Sofia, Maria e Grazieli) possuíam redes mais amplas do que possuem atualmente. As participantes mencionadas relatam que, antes da ocorrência do TA, conversavam com os amigos de infância, da escola e do trabalho, mantendo contato frequente. Entretanto, nota-se que não se tratava de um contato significativo, uma vez que as participantes se caracterizavam como quietas e retraídas, tendo sido assim ao longo de toda a vida. Fernanda e Carolina relatam que "sempre foram de poucos amigos", saíam pouco e preferiam ficar sozinha, indicando a existência de redes sociais escassas. Nesse sentido, é possível perceber que traços de introversão, retraimento e condutas evitativas encontram-se presentes na dinâmica das participantes.

No que concerne à realização de atividades de lazer antes da ocorrência do TA, todas as participantes relataram o costume de ir ao shopping, bares e cinema, com exceção de Fernanda. Esta última considera que "tem uma personalidade, assim, de não ter muitos amigos", e confidencia que nunca teve atividades de lazer e se sente bem com isso, não gostaria que fosse diferente. É possível notar, então, que a vida social das participantes envolvia um número relativamente considerável de membros em suas redes, com quem elas realizavam algumas atividades.

As características de personalidade mencionadas pelas participantes durante as entrevistas (introversão, retraimento, preferência pela solidão, entre outros) corroboram a literatura científica, que sugere que a personalidade de mulheres com AN - como é o caso das participantes Fernanda, Bárbara, Sofia e Maria -, é geralmente marcada por traços de inferioridade, inadequação e insegurança, perfeccionismo, obsessividade, compulsividade, emoções negativas, retraimento e condutas de evitação (Borges et al., 2006; Cassin \& Von Ranson, 2005; Nilsson, Sundboom, \& Häglöff, 2008; Peres \& Santos, 2006). As mulheres com BN, tais como Sissi, Carolina e Grazieli, geralmente apresentam comportamentos impulsivos, traços histriônicos e transtorno de personalidade do tipo borderline (Kaye, 2008; Borges et 
al., 2006; Paccola, 2006;), além de pensamentos e emoções desadaptativas, que comumente resultam em atitudes caóticas que comprometem inúmeros aspectos da vida, tais como os estudos, a vida profissional e as relações amorosas (Limbert, 2010; Oliveira \& Santos, 2006).

Considerando esses pressupostos, infere-se que os aspectos da personalidade das participantes, retirados dos discursos nas entrevistas, e também sugeridos pela literatura especializada, exercem influência crucial na dificuldade que as participantes apresentam no estabelecimento de vínculos com as pessoas de seu meio. O retraimento e a introversão, assim como os comportamentos impulsivos e as atitudes caóticas, parecem acarretar em uma dificuldade de interação, que resulta na escassez de membros das redes sociais (Limbert, 2010) e na realização de poucas atividades de lazer. Considerando-se a relação existente entre as interações sociais e a qualidade de vida dos indivíduos (Sluzki, 1997), pode-se pensar que a escassez de membros nas redes das participantes e a ausência de atividades de lazer mantêm estreita relação com a cronicidade do quadro de TA.

\subsubsection{Subcategoria A1b - Dinâmica familiar}

Segundo os relatos de três participantes durante a entrevista (Sofia, Sissi e Grazieli), a dinâmica familiar antes da ocorrência do TA era marcada por relacionamentos permeados por brigas, discussões e violência física. Sofia relata que o pai fazia uso abusivo de álcool, a mãe apresentava quadro depressivo e o casal brigava constantemente. Tantas brigas parecem ter resultado em um distanciamento emocional entre os membros da família "desde sempre", segundo o discurso da participante. No caso de Sissi, o pai mantinha relacionamentos extraconjugais e era agressivo e violento com a esposa, chegando a ter sido preso por violência física contra a mesma, permanecendo na prisão por alguns meses. A participante relata que "cresceu com transtorno de paternidade", pois sempre teve muita raiva e medo do pai, o que causou um distanciamento entre os dois.

Grazieli, por sua vez, não menciona violência física, mas sim um distanciamento por parte dos pais desde a sua infância: os pais sempre trabalharam e "não a acompanhavam". Além disso, a participante também relata que sempre se sentiu sufocada e cobrada pelo pai, que não a deixava sair e nem dormir na casa das amigas. Grazieli menciona ainda a relação disfuncional com o irmão, com quem sempre brigou muito, uma vez que sentia que "tudo era pra ele, do jeito dele". Fernanda também relata que, antes da ocorrência do TA, havia um distanciamento entre os membros de sua família, uma vez que suas irmãs "pensavam 
muito em si". Entretanto, no que concerne à relação com a mãe, Fernanda relata que sempre foi bastante próxima. A participante Maria menciona que sempre teve uma relação distante com o pai, que foi caracterizado como autoritário e uma pessoa como quem era difícil se estabelecer uma relação de intimidade. Houve um período, muito anterior à instalação do TA, que Maria foi próxima da mãe, mas relata que essa relação foi se "desgastando" com o tempo. Bárbara foi a única participante que relatou a existência de relacionamentos "mais tranquilos" entre os familiares antes da instalação do TA.

No que concerne às relações familiares, autores como Bryant-Waugh e Lask (1995), Lane (2002) e McNamara e Loveman (1990) pontuam que as famílias de pacientes com TA geralmente apresentam desarmonia, pouco afeto e respeito entre seus membros, comunicação empobrecida, escassa habilidade para a resolução de conflitos, mães excessivamente controladoras e pais ausentes. Os relatos das participantes e a configuração dos Genogramas e dos Mapas de Redes corroboram os achados da literatura, uma vez que evidenciaram que as relações familiares eram marcadas por conflitos, brigas e sensação de incompreensão, além de ausência de empatia.

A ausência da figura paterna foi percebida nos casos de Fernanda e Carolina, que não mencionam o pai durante as entrevistas, exceto quando interrogadas a esse respeito no momento da construção do Genograma. Nos casos de seis outras participantes (Maria, Sofia, Sissi, Juliana, Estrelinha e Grazieli), nota-se a ocorrência de graves conflitos entre elas e seus pais, conflitos estes que parecem ter culminado em um distanciamento significativo, corroborando os dados trazidos pelos autores mencionados.

Evidenciou-se a existência de conflitos também na relação de duas participantes (Carolina e Marina) com seus filhos. As duas mulheres mencionadas confidenciaram terem sido física e verbalmente violentas, principalmente na época em que os sintomas de TA encontravam-se mais agravados. Entretanto, atualmente, ambas relatam relações que alternam entre épocas mais conflituosas e de maior demonstração de afeto. $O$ discurso de Marina marca também uma relação de fusão com a filha, na qual há uma mistura de sentimentos de amor e ódio.

É, eu xingo eles, fico brava com eles, ponho eles pra dentro, se precisar dou uns "tampa olho" neles, mas não é tão constante mais, né.

Minha filha tem onze anos, só que sabe, ela tá do meu tamanho, o corpo dela é lindo. Lindo, lindo, lindo. Quando ela tá se trocando, tá assim de calcinha e sutiã, eu fico assim, babando. Teve época que assim, eu e ela brigávamos 
constantemente, até comentei com a psicóloga, ela disse: "Mas não é certo, ela é uma criança, tá se desenvolvendo agora". E ela, pra me provocar ela ficava me insultando: "Olha o meu corpo, você não tem meu corpo".

\subsubsection{Categoria $A 2$ - Atribuições de significados relacionados ao início do TA}

Essa categoria trata dos fatores que as participantes consideram como principais precipitantes do transtorno. São eles: autoestima rebaixada e série de eventos estressores.

\subsubsection{Subcategoria A2a - Autoestima rebaixada}

Diversos autores (Nilsson et al., 2008; Peres \& Santos, 2006; Shea \& Pritchard, 2007) pontuam que o comprometimento da autoestima é uma característica marcante do funcionamento mental das mulheres com TA. Durante o processo de análise das entrevistas, foi possível notar que havia nos discursos das participantes traços bastante significativos de autoestima rebaixada, que corroboram a literatura. Esse dado pode ser ilustrado por meio do relato de três participantes (Bárbara, Sofia e Grazieli), que mencionam o hábito de fazer comparações entre si mesmas e outras pessoas, a saber: mãe e irmãs (Bárbara e Sofia), amigas do balé (Grazieli) e namorada do menino por quem era apaixonada (Bárbara). É importante ressaltar que essas comparações sempre culminavam em um sentimento de inferioridade por parte das participantes, ou seja, elas consideravam-se sempre em desvantagem em relação às outras pessoas.

Bárbara relata que possuía desejo de ser como a mãe e a irmã, que ela considera "miúdas". Além disso, o jovem que foi o "primeiro amor" de Bárbara na pré-adolescência, começou a namorar uma menina que, segundo a participante, era muito magra. Ao realizar esses tipos de comparações, a participante menciona um sentimento de inferioridade, que culmina em um comprometimento da autoestima.

[...] Você vai tendo perdas, aí você começa a associar: "Nossa, será que é por que eu sou gorda?" [...] Mas aí você começa, sabe, a associar isso, aí eu comecei a gostar de um menino na época, tem aquele primeiro menino que você gosta, sabe, tudo... De repente a pessoa não quer mais nem olhar na sua cara, não quer falar com você, você vê ele com uma menina super magra, aí você começa a associar tudo, sabe, você não tinha maturidade o suficiente, você vai tendo perdas, assim... Você já vai sentindo aquele seu chão cair... De repente, você, sabe... Você começa assim: "Nossa, eu acho que porque eu sou gorda, isso, aquilo, todo mundo me chama de "bulufas" ou chama atenção que eu to comendo demais", então... 
Sofia, por sua vez, relata que as irmãs e a mãe "viviam fazendo dieta", pois "eram gordinhas". A participante relata um medo intenso de ser como as três e, juntamente com um quadro depressivo - no qual Sofia apresentava desejo de morrer, de "ir sumindo aos pouquinhos" -, esse motivo a levou a iniciar a restrição alimentar. No entanto, nota-se um rebaixamento cada vez mais significativo da autoestima da participante, uma vez que, mesmo com uma grave perda de peso, ela continuava sentindo-se mal em relação a si mesma e ao seu corpo. Grazieli, por sua vez, relata que costumava ouvir das pessoas que "não tinha corpo de bailarina", e se sentia "tocada" quando ouvia comentários desse tipo. Além disso, a participante menciona que sofria muita pressão para emagrecer, já que, segundo ela, "a maioria das meninas eram magras".

Levando-se em conta que a insatisfação das participantes não se trata, em um primeiro momento, de uma insatisfação com o corpo propriamente dito, e considerando-se que a magreza é um símbolo social de beleza e sucesso (Morgan, Vecchiatti, \& Negrão, 2002; Nilsson et al, 2007; Oliveira \& Santos, 2006), pode-se pensar na existência de uma insatisfação consigo mesma, em um sentido mais amplo, que parece ter sido redirecionada para o corpo em uma tentativa de compensação de aspectos psíquicos fragilizados ou de obter sentimento de controle sobre si.

\subsubsection{Subcategoria $A 2 b$ - Série de eventos estressores}

Morgan, Vecchiatti e Negrão (2002) pontuam que a ocorrência de experiências adversas - que também podem ser denominadas como eventos estressores - é considerada um dos fatores que interagem entre si de uma forma complexa e precipitam o quadro de TA. Tais eventos podem englobar: comentários sobre o peso, término de relacionamento, perda de um ente querido, separação dos pais, entre outros. Nota-se que a ocorrência de eventos desse tipo aparece nos discursos de oito participantes do presente estudo (Maria, Bárbara, Grazieli, Sissi, Juliana, Marina, Estrelinha e Fernanda).

No caso de Maria, o casamento na adolescência e a separação após poucos anos de união parecem ter resultado na precipitação do TA. A participante relata que se tratou de um relacionamento bastante conturbado, pois o ex-marido "não aceitava o jeito dela, a sua personalidade". No entanto, a participante permanecia em silêncio quando questionada a respeito de sua adolescência, restringindo suas respostas apenas a: "[...] aconteceram muitas coisas, não consigo ligar exatamente a alguma coisa". Para Bárbara, a perda de 
pessoas próximas - que, segundo a participante, se afastaram por "estarem seguindo seus caminhos", e não por motivos relacionados a ela mesma -, juntamente com os apelidos depreciativos que recebia da irmã e dos amigos da escola durante a infância e a préadolescência - era chamada de "bulufas" - exerceram influência sobre a instalação do transtorno. Além disso, a participante era apaixonada por um jovem da escola que começou a namorar uma menina, caracterizada por Bárbara como "super magra". A soma desses fatores, que a participante denominou como "perdas", foi associada ao peso e à forma corporal de Bárbara, que passou a buscar o emagrecimento como forma de provar algo às pessoas: "Eu queria mostrar pros outros que eu podia". Comentários a respeito do peso também foi mencionado por Juliana como um dos fatores precipitantes do TA, principalmente pelo fato desses comentários terem sido tecidos pelo pai.

Grazieli considera que sentir-se cobrada e sufocada pelo pai desde a infância parece ter gerado sentimentos de angústia e ansiedade, que a participante "desconta" na alimentação excessiva e busca alívio na purgação, por meio dos vômitos. No entanto, notase a existência de uma cobrança autodirigida por parte de Grazieli, ou seja, a própria participante se cobra muito: considera que precisa ser magra para o balé, precisa trabalhar bem na banca dos pais e não pode gastar dinheiro em função de uma dívida que os pais possuem. No caso de Grazieli, a dívida dos pais parece ter sido o evento estressor do TA, uma vez que a cobrança - tanto por parte do pai quanto de si mesma - foi intensificada.

Traição do marido (Marina) e término de um namoro longo (Estrelinha) também surgiram como eventos que levaram à ocorrência do TA. Estrelinha confidenciou uma série de conflitos relacionados ao namoro que culminaram em uma separação do casal. Essa separação, juntamente com o fato de que o namorado "não dava atenção" a ela, fez com que a participante se sentisse muito triste e com baixa autoestima, despertando o desejo de perder peso. Marina, por sua vez, relata que, ao saber da havia sido traída pelo marido, considerou que o emagrecimento seria uma forma de fazer com que ele se interessasse por ela novamente.

Eu achei, assim, que eu amava ele demais, eu não queria perder ele, imaginava que pelo fato de ele ter me traído com a minha prima, e minha prima era assim, bem magrinha, eu nunca fui gorda, sempre tive esse corpo, eu pensei assim: "Nossa ele gosta de mulher bem magra, então se eu ficar assim bem magra igual ela, ele nunca vai largar de mim, não vai me abandonar". Então foi onde eu comecei a comer e vomitar, fazer regime, daí eu comecei a tomar um monte de remédio, tomei um monte de chá, foi assim que começou tudo. 
Por fim, Fernanda relata que sempre morou com a avó em um estado distante, mas precisou morar com os pais aos 19 anos de idade. Nessa época, a participante trabalhava durante a noite em um hospital e, segundo seu discurso na entrevista, passou a não ter mais vontade de comer. Quando comia, vivenciava episódios de compulsão alimentar. Fernanda não soube nomear os fatores que ela considera responsáveis pelo desenvolvimento TA, mas mencionou esse período de mudanças em sua vida como possível fator de influência sobre a precipitação do quadro psicopatológico.

\subsubsection{Categoria A3 - Vivências e dificuldades decorrentes do TA}

A categoria A3 diz respeito aos fatos e dificuldades que passaram a ser vivenciadas pelas participantes em função do TA. Essas vivências englobam: ambivalência entre anseios e necessidades, incômodo com o julgamento das pessoas, viver em função da alimentação, viver em uma "montanha russa" e mudanças drásticas na rotina.

\subsubsection{Subcategoria A3a - Ambivalência entre anseios e necessidades}

Três participantes (Bárbara, Sofia e Maria) relataram vivenciar sentimentos de ambivalência em relação à alimentação desde a instalação do TA. Trata-se de uma ambivalência entre a necessidade fisiológica e biológica de se alimentar, contra o desejo de perder peso, que implicaria no ato de se alimentar de forma restritiva. Os discursos dessas participantes eram permeados por relatos acerca de uma pressão interna e de uma luta constante contra si mesmas, que têm como objetivo exercer o autocontrole e negar a fome.

Nos momentos em que o autocontrole não impera, todas as participantes, com exceção de Sofia, relatam uma ingestão bastante significativa de alimentos, em um curto período de tempo. Segundo o DSM-IV-TR ${ }^{T M}$ (Associação Americana de Psiquiatria, 2002), tal ingestão alimentar pode ser caracterizada como compulsão alimentar. São ingeridos pacotes de bolacha, caixas de chocolate, panelas de feijão, entre outros. Segundo o discurso destas, a compulsão alimentar é geralmente seguida da vivência de sentimentos de culpa, por terem consciência de que o alimento ingerido irá engordá-las. Como consequência, as participantes realizam os rituais purgativos e compensatórios - tais como a provocação de vômitos, a realização de exercícios físicos excessivos e o uso abusivo de laxantes, diuréticos e anorexígenos - como uma forma de evitar o ganho de peso, e também como uma forma de alívio para a angústia sentida após a compulsão alimentar. Esses dados corroboram a 
literatura científica, que preconiza que indivíduos acometidos por sintomas bulímicos apresentam episódios de compulsão alimentar, seguidos de sentimentos de culpa e, consequentemente, realizam a purgação (Paccola, 2006).

\subsubsection{Subcategoria A3b - Incômodo com o julgamento das pessoas}

$\mathrm{O}$ ato de esconder o TA das pessoas com quem convivem emergiu no discurso de sete participantes (Carolina, Sissi, Grazieli, Ana, Marina, Amanda e Sofia), como decorrência de um medo de receber críticas. Estas relatam que as pessoas à sua volta costumam expressar suas opiniões a respeito do peso e do transtorno das participantes de uma forma bastante inadequada e que desperta um incômodo, fazendo com que elas tenham preferência por esconder o TA. O caso de Grazieli ilustra bem o tipo de comentários que as participantes consideram inadequados: a participante dançava balé e expressou o desejo de ser magra para "ter corpo de bailarina". No entanto, apesar de não se considerar acima do peso, Grazieli sentia-se muito angustiada quando ouvia comentários como: "Você é bailarina? Você não tem corpo de bailarina". Ao relatar esse evento, a participante apresenta-se bastante angustiada, demonstrando o impacto negativo que alguns comentários provenientes das pessoas do meio podem exercer sobre as suas emoções.

Carolina relata que "as pessoas nunca vêm pra te ajudar, elas vêm pra te criticar". Ou seja, a participante considera que as pessoas costumam expressar suas opiniões com o intuito de despertar sentimentos negativos nos outros, e por isso prefere esconder o quadro de TA. Sissi interpreta o incômodo que sente com o julgamento das outras pessoas a partir da vergonha que ela própria sente do ato de vomitar: ela relata que o vômito é algo "nojento", que "desperta asco nas pessoas", e por sentir esse "nojo", ela acredita que as pessoas também sentiriam e a julgariam de forma negativa. Sofia expressa seu incômodo por meio da descrição dos grupos de apoio dos quais participou quando esteve internada no Hospital Dia: a participante relata que os membros do grupo não entendiam que o TA "é uma doença, algo que ela não tem controle". Por esse motivo, Sofia relata que tinha muita dificuldade para participar dos grupos e, quando participava, permanecia em silêncio.

Considerando-se a dificuldade que as mulheres com TA apresentam no plano dos relacionamentos interpessoais (Borges et al., 2006; Cassin \& Von Ranson, 2005; Nilsson, Sundboom, \& Häglöff, 2008; Oliveira \& Santos, 2006; Peres \& Santos, 2006), pode-se pensar na existência de uma limitação, por parte das participantes do estudo, de questionar e 
argumentar quando algum julgamento a seu respeito é exposto por terceiros. A introversão e as condutas de evitação, típicas de mulheres com AN (Peres \& Santos, 2006), parecem fazer com que as participantes se coloquem em uma posição passiva frente aos comentários negativos a seu respeito. Acredita-se que essas reações de evitação do incômodo com o julgamento de outras pessoas podem resultar em um distanciamento social das pessoas do meio ambiente onde as participantes vivem, restringindo o tamanho das redes sociais.

Além disso, acredita-se que a constante desconfiança e o consequente distanciamento das pessoas com quem as participantes convivem pode acarretar na diminuição do potencial de apoio das redes sociais. Levando-se em conta que o bem estar é proporcionado pelo apoio social proveniente das relações sociais significativas (Vaux, 1988), nota-se que esse apoio encontra-se comprometido nos casos das participantes mencionadas, podendo resultar em inúmeros agravos à saúde e ao quadro de TA.

\subsubsection{Subcategoria $A 3 c$ - Viver em função da alimentação}

Nota-se, no discurso das participantes, que o alimento parece ocupar várias dimensões de suas vidas, uma vez que ele está presente não apenas nas refeições, mas também nas saídas com os amigos, no relacionamento com a família, no pensamento das participantes durante as aulas, no trabalho e em várias outras atividades. Seis participantes (Sissi, Marina, Grazieli, Amanda e Maria) relatam sentir-se "perseguidas" pelo alimento, ou seja, sentem como se o alimento estivesse sempre presente, não as deixando esquecê-lo.

Maria confidencia que trava lutas constantes e diárias contra o alimento, pois tem consciência de que precisa dele para sobreviver, mas não quer ingeri-lo em função do medo de engordar. A participante relata que essas "lutas" acontecem a todo momento, uma vez que o alimento ocupa quase todos os seus pensamentos, e ela precisa afastá-los. Além disso, há também a pressão externa, por parte da família, para que a participante se alimente, o que intensifica a dificuldade de "vencer" essas lutas.

Ah, era muito difícil, eu não conseguia é... Era uma luta constante porque eu olhava pra comida e eu não... Não queria comer porque eu sabia que... Por menor que fosse o pedacinho que eu comesse... Aquilo lá já ia me engordar muito, então era uma luta constante... Era uma briga mesmo. 
Grazieli e Sissi apresentaram discursos semelhantes no que concerne ao papel do alimento em suas vidas: ambas relatam que o alimento constitui a maioria de seus pensamentos, pois avaliam a quantidade calórica de todos os alimentos e verificam se irão engordar ao realizar determinadas tarefas (tais como: comer determinado alimento, ou mesmo sair de casa, ir ao shopping, entre outros). Grazieli relata que o alimento a "persegue" até mesmo em sonho, quando sonha que come sem parar. O sentimento vivenciado por ambas as participantes é de muita angústia e "tortura".

No entanto, nota-se que os sentimentos negativos não estão relacionados apenas com o alimento em si - por exemplo, em termos de quantidade calórica -, mas também com o que ele representa. Os discursos de Fernanda e Grazieli demonstram que o alimento serve como algo que suporta intensas emoções, e que pode ser ingerido ou descartado, dependendo da necessidade de quem o manipula.

Ficava muito triste, sabe? Muito triste... E assim, tinha esse sintoma, quando eu tava... Começava a entrar em compulsão eu geralmente ficava assim, me dava uma crise de ansiedade... Ansiedade, muita ansiedade, de repente eu ficava assim... É... Angustiada, sabe? Triste... Todo esse sintoma e... Eu precisava comer muito... E comer... Vomitar... Comer... Vomitar...

Assim, as participantes relatam que quando se sentem tristes e angustiadas, "precisam comer muito", "comer sem parar, sem saber o que quer". Os vômitos surgiram no discurso das participantes como alívio para angústia, uma vez que elas podiam "colocar aquilo para fora".

O fato de não poder sair de casa também surgiu como dificuldade decorrente do TA para três participantes (Marina, Amanda e Juliana). As três relataram que evitavam participar de eventos sociais, uma vez que sabiam que não poderiam comer, ou que teriam que criar táticas para provocar os vômitos sem que ninguém percebesse. Nota-se, então, um comprometimento da realização de atividades de lazer com as pessoas de seu meio ambiente.

\subsubsection{Subcategoria A3d - Viver em uma "montanha russa"}

Ao analisar os momentos nos quais as participantes vivenciavam maiores dificuldades com a alimentação, notou-se que cinco delas (Carolina, Sofia, Estrelinha, Marina e Fernanda) mencionaram oscilações de humor, que eram acompanhadas por períodos de maior 
compulsão e purgação alimentar. Ou seja, as referidas participantes apresentam discursos bastante semelhantes no que diz respeito às oscilações de humor: as três relatam que, quando estão "muito nervosas", ansiosas e/ou angustiadas, ingerem alimentos em maiores quantidades e realizam rituais de purgação com maior frequência. Sofia relata que "tem fases em que está bem e consegue comer coisas diferentes das que está acostumada, e tem épocas que não consegue comer nada". Fernanda considera que se encontra em uma fase melhor e com menos oscilações de humor, e atribui essa melhora ao tratamento psicoterápico no GRATA e ao uso de medicamentos.

Entretanto, apesar das oscilações de humor, nota-se que quatro participantes (Sofia, Fernanda, Grazieli e Bárbara) já apresentaram quadros depressivos, nos quais manifestavam o desejo de tirar a própria vida. Bárbara, Fernanda e Sofia relatam que não viam mais sentido em suas vidas e tinham vontade de morrer. Fernanda acredita que a baixa autoestima era o principal fator para a ausência do desejo de viver. Grazieli relata que sentia muita angústia e ansiedade, e vivia constantemente em busca de formas de alívio. Por "não aguentar mais" sentir angústia, a participante relata que já pensou em se matar. Apesar dos intensos pensamentos de morte relatados pelas quatro participantes mencionadas, Fernanda e Amanda foram as únicas que tentaram de fato tirar a própria vida: Fernanda misturou vários medicamentos e os ingeriu, e Amanda se jogou da escada da instituição hospitalar na qual encontrava-se internada. As participantes foram rapidamente socorridas, e as tentativas não apresentaram consequências graves.

O sentimento de incapacidade e de ser vista como incapaz pelas pessoas de seu meio surgiu no discurso de três participantes (Fernanda, Carolina e Sofia) como fator mobilizador de angústia, que parece estar intimamente relacionado com o quadro depressivo dessas participantes. Fernanda e Sofia relatam que as visitas constantes a hospitais e a impossibilidade de realizar as atividades que realizavam antes da ocorrência do TA principalmente trabalhar -, despertavam sentimentos de incapacidade que acentuavam a angústia e a depressão das participantes. Fernanda menciona que sofreu um rebaixamento em sua função no trabalho devido ao comprometimento de sua saúde e da consequente dificuldade que apresentava para realizar os serviços que antes realizava com facilidade. Esse rebaixamento despertou sentimentos de menosvalia na participante que, segundo seu discurso durante a entrevista, agravou o quadro de TA. Carolina demonstra um medo 
intenso de se tornar uma pessoa dependente e incapacitada de realizar suas atividades - " $a$ coitada" -, afirmando que, caso isso acontecesse, iria se sentir bastante angustiada.

Nota-se que os sentimentos negativos que marcam as oscilações de humor das participantes - dentre eles: autovalorização negativa, incapacidade e angústia por ser vista como incapaz - são típicos de quadros de autoestima rebaixada. Karpowicz, Skärsäter e Nevonen (2009) sugerem que os comportamentos de restrição e purgação alimentar são secundários à primazia de fatores emocionais na etiologia dos quadros de TA, principalmente a autoestima. Os referidos autores pontuam que a autoestima rebaixada é determinante nos sentimentos de solidão, depressão e ansiedade, ou seja, a experiência de conforto consigo mesmo e com o próprio corpo pode ser considerada como elemento central do bem-estar do indivíduo. Levando-se em conta que a autoestima encontra-se significativamente rebaixada nos casos das participantes mencionadas, acredita-se que os episódios de maior compulsão e purgação alimentar estejam intimamente relacionados com fatores emocionais, que são direcionados para a relação com o corpo e, consequentemente, para a alimentação.

\subsubsection{Subcategoria $A 3 e$ - Mudanças drásticas na rotina}

Seis participantes (Bárbara, Sofia, Amanda, Grazieli, Fernanda e Maria) relataram que, desde a instalação do TA, suas atividades de vida diária sofreram modificações significativas. Trata-se de atividades que eram realizadas cotidianamente, ou seja, que faziam parte do dia-a-dia das participantes, e que foram excluídas ou modificadas, despertando o sentimento de impotência e incapacidade.

A necessidade de visitar médicos e hospitais passou a ser uma constante na vida de Maria, Bárbara, Fernanda e Sofia. Juntamente com as inúmeras e recorrentes internações, essa necessidade resultou em um afastamento do trabalho para Maria, Amanda e Sofia, da escola para Bárbara e em um rebaixamento de cargo no trabalho para Fernanda. Sofia também menciona que, antes da instalação do TA, tinha o hábito de sair com os amigos, mas esse hábito foi excluído de sua vida, uma vez que a participante evitava situações que envolvessem contato com o alimento. Além disso, ocasiões de encontros sociais com amigos se caracterizavam como oportunidades para que os mesmos questionassem Sofia a respeito do seu emagrecimento e de seus hábitos alimentares, situação esta que despertava extrema angústia na participante. No caso de Grazieli, ela relata que costumava passar muito mal em 
função da alimentação desregrada e dos comportamentos purgativos, e acabou por perder vários dias de aula em decorrência desse mal estar, durante um longo período de tempo.

Juntamente com as mudanças drásticas na rotina, nota-se que também houveram perdas significativas na vida das participantes, em termos de redes e apoio social. Uma vez que o trabalho e a escola são partes cruciais da rede social de um indivíduo e potenciais fontes de apoio, acredita-se que o afastamento das redes mencionadas pode ter resultado em uma restrição do número de membros e do apoio recebido por meio destas.

Sluzki (1997) pontua que inúmeras evidências científicas comprovam a existência de uma relação direta entre as redes sociais e a qualidade de vida dos indivíduos. Considerando-se que as redes sociais das participantes já eram escassas antes da ocorrência do TA, pode-se pensar que o afastamento do trabalho, da escola e dos amigos tenha resultado em mudanças drásticas que tomaram proporções bastante significativas na vida das participantes, pois além de trazerem modificações nos hábitos cotidianos aos quais elas estavam acostumadas, também restringiram o número de membros da rede social. Acredita-se que o comprometimento das redes sociais das participantes tenha exercido um impacto negativo na experiência de identidade e bem-estar (Sluzki, 1997), levando aos sentimentos de impotência e angústia relatado por elas durante as entrevistas.

\subsubsection{Categoria A4 - Sentimentos vivenciados após a instalação do TA}

A categoria A4 diz respeito aos sentimentos que as participantes relataram vivenciar com mais frequência desde a ocorrência do quadro psicopatológico. Os sentimentos mencionados foram: angústia, dor emocional e ansiedade; solidão, tristeza e vazio; vontade de "sumir aos poucos". Nota-se que o TA é vivenciado com significativo sofrimento, uma vez que os sentimentos mencionados pelas participantes como resultantes do quadro despertam apenas emoções negativas e apresentam efeitos prejudiciais, tanto sobre a gravidade do TA quanto sobre as redes sociais das participantes.

\subsubsection{Subcategoria A4a - Angústia, dor emocional e ansiedade}

O sentimento de angústia surgiu como elemento central na entrevista de cinco participantes (Bárbara, Sofia, Maria, Fernanda e Grazieli), quando descreviam as emoções que passaram a ser vivenciadas desde a instalação do TA. Esse sentimento foi mencionado inúmeras vezes pelas participantes, sendo apresentado juntamente com expressões de 
afetos bastante negativos, tais como dor emocional e ansiedade. Cooper, Deepak, Grocutt e Bailey (2007) sugerem que a distorção de imagem corporal e a insatisfação com o próprio corpo, típicas dos quadros de TA, estão geralmente relacionados a emoções negativas, destacando-se a angústia.

Bárbara relata que os sentimentos de angústia e ansiedade constantes estão relacionados com a busca de algo, que a própria participante não sabe do que se trata, mas acredita que o emagrecimento poderia ajuda-la a conseguir o que queria.

Não sei, parece que... Você busca alguma coisa assim... Que você... Ao mesmo tempo também não sei o que é, sabe assim? Eu busco uma coisa assim, como se fosse uma solução perfeita pra minha vida, mas ao mesmo tempo eu não acho o que é, assim... [...] E acho que essa ansiedade, essa angústia, assim... É exatamente por isso, que você tá em busca de alguma coisa e não sabe o que é, assim.

Nos casos de Sofia e Maria, a angústia estava relacionada com a ambivalência entre a necessidade de comer e o desejo de emagrecer. Sofia relata a vivência de um sofrimento intenso por "não conseguir comer", mesmo sabendo que o alimento era necessário para a sua sobrevivência. Além disso, o pensamento de que há inúmeras pessoas no mundo que passam fome e que a participante "tinha alimento dentro de casa, mas não queria comer", intensificava seus sentimentos de angústia, dor e ansiedade. Maria descreve situações nas quais vivenciava intensas "lutas internas", nas quais buscava combater a necessidade e o desejo pelo alimento. Tais lutas se tornavam bastante angustiantes, uma vez que os pensamentos acerca da alimentação eram constantes e a necessidade desta para a sobrevivência era irrefutável.

Para Fernanda, os episódios de compulsão alimentar estavam relacionados aos sentimentos de angústia e ansiedade. No entanto, a participante não consegue distinguir se esses sentimentos eram anteriores ou posteriores aos episódios: Fernanda relata inúmeras emoções negativas vivenciadas ao mesmo tempo, juntamente com um desejo muito intenso de comer e vomitar. Grazieli, por sua vez, relata que os sentimentos de angústia e ansiedade eram constantes em sua vida, mas eram intensificados quando ela pensava nas situações que costumava vivenciar: conflitos familiares, sentir-se sufocada pelo pai, não poder sair de casa, entre outros. A participante considera que "colocava a angústia na comida", pois o vômito possibilitava a sensação de alívio das emoções negativas. 
Eu lembro que, muitas vezes, assim, eu colocava a angústia na comida. Eu queria... Toda angústia, toda frustração, eu queria comer, colocava raiva na comida, depois jogar aquilo, dava aquela sensação de alívio... Porque na hora que você come, come, come, come, come, parece que aquilo enche, enche, enche dá uma sensação de mal estar... Mas na hora que você vomita, dá aquela sensação de alívio, assim... Sair tudo aquelas coisas ruins, assim...

Limbert (2010) destaca a existência de uma relação entre o baixo grau de satisfação com o apoio social e a sintomatologia de TA. Considerando-se que o apoio social é proveniente das redes sociais, e que essas redes exercem influência significativa na qualidade de vida do indivíduo (Sluzki, 1997; Vaux, 1988), pode-se pensar que a percepção que as participantes possuem do apoio social recebido talvez seja bastante negativa, uma vez que a qualidade de vida das mesmas encontra-se comprometida. Acredita-se que a satisfação com o apoio recebido implicaria em um bem estar por parte das participantes, e em um senso de identidade mais consolidado, que seriam incongruentes com os sentimentos de angústia e ansiedade relatados durante as entrevistas.

\subsubsection{Subcategoria A4b - Solidão, tristeza e vazio}

A sensação de "estar sozinha mesmo no meio de muitas pessoas" foi mencionada por Carolina, Sissi e Sofia, juntamente com um intenso sentimento de tristeza e vazio. Sofia descreve esse sentimento como "um vazio que nunca preenche", enquanto que Sissi, Juliana e Carolina, em contrapartida, relatam que "a alimentação as preenche": Carolina sente-se "aconchegada e saciada" após a ingestão alimentar. Sissi relata que sente um vazio que não sabe do que se trata, e apesar de suas tentativas de distração - que incluíam sair de casa e realizar atividades físicas -, acabava comendo de forma excessiva, buscando aplacar a sensação de vazio. No entanto, nota-se que a compulsão alimentar, nos casos de Sissi e Carolina, se trata de um preenchimento apenas momentâneo, uma vez que os episódios de compulsão são recorrentes. Ou seja, o vazio volta a se instalar mesmo após a alimentação.

Fernanda também menciona o sentimento de vazio e a dificuldade de explicá-lo, descrevendo-o apenas como "uma sensação horrível de vazio", que desperta muita tristeza e sofrimento. No entanto, o sentimento de solidão mencionado pela participante foi relacionado com a dificuldade que ela possui em estabelecer contatos sociais, que comprometia o número de membros de suas redes sociais e as possibilidades de interação. 
Bárbara também menciona o sentimento de solidão, e coloca-o como resultante do isolamento social no qual ela própria se inseriu. A participante relata que se afastou de seus amigos da escola quando o TA começou a se instalar e, aos poucos, foi se excluindo de suas redes sociais. Dessa forma, restaram poucas pessoas com quem a participante tinha contato, despertando o sentimento de solidão.

Evidenciou-se, nos discurso das participantes, que os sentimentos de tristeza e vazio parecem estar relacionados à dificuldade no estabelecimento de contatos sociais e vínculos sólidos com os membros de suas redes, que implica em um afastamento de pessoas significativas, isolamento social e possível sentimento de solidão. Esse isolamento, por sua vez, parece resultar em uma escassez de relações interpessoais, restringindo assim o tamanho e a densidade de suas redes sociais (Sluzki, 1997). Em consequência dessa restrição, restam poucos membros nas redes sociais a quem as participantes podem se voltar nos momentos de mal estar e sofrimento, o que parece dar origem a sentimentos de solidão e vazio. Nota-se a existência de um círculo vicioso (Sluzki, 1997), no qual o TA afeta de forma negativa as redes sociais, causando, dentre outros, o isolamento social. Uma vez retraídas, ocorre um mecanismo de retroalimentação nas redes, onde as relações exercem um impacto negativo sobre o quadro psicopatológico, intensificando as emoções negativas vivenciadas, e assim progressivamente.

\subsubsection{Subcategoria A4c - Vontade de "sumir aos poucos"}

Os sentimentos de tristeza, solidão e vazio descritos na subcategoria anterior, assim como a ausência do desejo de viver, descrito na subcategoria A3d, também parecem estar estreitamente relacionados a uma vontade de "sumir aos poucos", mencionada por duas participantes (Sofia e Bárbara). Sofia relata que, após a ocorrência do TA, passou a se sentir muito triste, sozinha e deprimida, e costumava apresentar pensamentos recorrentes de tirar a própria vida. No entanto, nunca chegou a tomar atitudes nesse sentido, e por isso relata que gostaria de "ir sumindo".

Eu fiquei muito deprimida. Muito deprimida, muito isolada... Em novembro eu tive uma crise de ansiedade e daí pra cá que foi piorando. (...) Eu sei que de novembro pra cá eu sentia muita vontade de morrer, tinha muita vontade, só que eu nunca tive coragem de chegar e fazer nada assim... Cortar o pulso, tomar remédio, nada... Minha vontade era de ir sumindo, assim, aos pouquinhos sabe? (...) Mas a minha vontade era essa, era de deitar na cama e ir sumindo aos pouquinhos... 
Bárbara também relata um desejo de "sumir", em função dos inúmeros e intensos sentimentos negativos que a participante passou a vivenciar desde a instalação do quadro. Além disso, a participante também menciona uma "confusão" mental, na qual ela vivencia momentos de muito sofrimento por não saber qual era o seu real desejo - por exemplo, Bárbara menciona que tinha necessidade da presença constante da mãe, mas sentia muita raiva desta. Essa confusão mental despertava muito sofrimento, e foi relacionada pela participante com o desejo de morte.

Nota-se que, no discurso de Bárbara, Marina e Sofia, o emagrecimento grave parece estar relacionado ao desejo de "sumir aos poucos", ou seja, assemelha-se a uma forma de morte. Do ponto de vista da Teoria das Redes Sociais (Sluzki, 1997), pode-se pensar no desejo de morte como a ausência de uma identidade consolidada e da sensação de pertencimento a algo ou a algum lugar. Sluzki (1997) propõe que a identidade é construída e reconstruída ao longo da vida, por meio das interações com as pessoas que configuram nossas redes sociais - entre eles familiares, amigos, colegas de trabalho e outras pessoas com quem interagimos. Essa interação se trata de uma experiência psicossocial que proporciona ao indivíduo a sensação que ele é importante a alguém, de que ele pertence a um meio social. Essa experiência define e redefine o lugar do indivíduo no mundo ao longo do seu processo de desenvolvimento. Em contrapartida, quando as redes sociais encontramse retraídas, com seu potencial de apoio social comprometido, podem influenciar os processos psicossociais de desintegração, mal estar e adoecimento (Sluzki, 1997), podendo levar aos pensamentos de morte.

\subsubsection{Categoria A5 - Mudanças desejadas}

A categoria em questão diz respeito às mudanças que as participantes gostariam que acontecessem em suas vidas, tanto no que concerne ao quadro de TA quanto em outros aspectos, tais como relacionamentos sociais, afetivos, atividades profissionais, entre outros. No entanto, quando questionadas a respeito dessas mudanças, quatro participantes (Sofia, Grazieli, Bárbara e Fernanda) mencionaram apenas aspectos relacionados à dinâmica das relações familiares. Esses aspectos serão descritos a seguir. 


\subsubsection{Subcategoria A5a - Dinâmica das relações familiares}

Vários autores (Dimitropoulos et al., 2008; Kluck, 2008; Limbert, 2010; Marcos \& Cantero, 2009) apontam para a rede social familiar como sendo a principal fonte de apoio aos indivíduos acometidos por TA. Partindo-se da hipótese de que haveria relação entre o funcionamento familiar vulnerável e a emergência ou perpetuação do transtorno (Souza \& Santos, 2006), considera-se que mudanças nos relacionamentos e na dinâmica familiares se fazem necessárias para a melhora do quadro psicopatológico. Ao analisar o discurso das participantes acerca das mudanças desejadas em suas vidas, corroboram-se os pressupostos encontrados na literatura a respeito da importância do papel da família nos quadros de TA, uma vez que todas as mudanças desejadas dizem respeito à dinâmica familiar.

Dentre as mudanças desejadas pelas participantes, encontram-se: mais diálogo, proximidade e carinho entre os familiares (Bárbara, Ana, Sofia e Juliana); menos conflitos entre os irmãos (Grazieli); maior participação da família no tratamento (Sofia); mais união familiar (Fernanda); menos críticas (Ana). Três participantes (Maria, Carolina e Sissi) não apresentaram desejo de mudanças, relatando que estão satisfeitas com suas vidas e suas relações sociais.

Ah, eu sempre senti falta de um pai e de uma mãe, assim... Não vou falar presente, porque eles são presentes, mas eu sinto falta de um pai e de uma mãe, de colo, sabe? De carinho, coisas que eu nunca tive, assim... Mesmo quando eu era criança, porque sempre tinha muita briga e confusão, então eu nunca tive um carinho de mãe, de pai. Hoje é uma coisa que me faz falta, antes não me incomodava, mas hoje é uma coisa que me faz muita falta, ter carinho assim, sabe... O que eu mudaria era isso, assim... Eu queria ser mais próximo, queria que a gente fosse mais próximo, fizesse mais coisa juntos, de vez em quando... Isso que eu sinto falta.

Ah, tivesse mais assim... Conversa mesmo, sabe? Mais troca assim, de... Mais uma troca, sabe assim... Entre eu e eles... Também assim, de coisas que eles gostariam, coisas que eu gostaria, sabe? Acho mais nesse sentido, não isso de ameaça, sabe... Porque isso é muito ruim.

A literatura específica acerca dos TA coloca que as famílias de indivíduos com esses quadros são marcadas por desarmonia, histórias de traumas, padrões de comunicação confusos e falta de consistência na resposta dos pais ao transtorno da filha (Bryant-Waugh \& Lask, 1995; Lane, 2002; Soenens et al., 2008). Além disso, Dallos e Denford (2008) sugerem a existência de um predomínio de vínculos problemáticos entre os membros da família, 
discussões frequentes, desconforto e relação negativa com a alimentação. Os autores mencionados propõem que esses aspectos, típicos da dinâmica familiar de mulheres com TA, podem ser considerados fatores precipitantes ou mantenedores do quadro.

No entanto, apesar de todos os conflitos familiares relatados pelas participantes e evidenciados pela literatura, o fato das participantes expressarem o desejo de mudanças nesse sentido parece apontar para uma importância central da família como rede de apoio social. Acredita-se que as participantes consideram a família como centro de sua influência interpessoal (Bullock, 2004), e gostariam que os padrões de relacionamento pudessem se tornar mais saudáveis, de modo a contribuir com a melhora do quadro de TA.

\subsection{Eixo B - Configuração das redes sociais significativas}

O segundo eixo de análise desta pesquisa abordou dados provenientes da confecção dos Mapas de Redes e dos Genogramas, complementados com dados retirados dos discursos das participantes nas entrevistas. Esses dados dizem respeito ao papel desempenhado pelos membros das redes sociais significativas em face do enfrentamento do TA das participantes, os atributos dos vínculos estabelecidos entre as participantes e os membros das redes e os tipos de ajuda recebida desses membros. Além disso, também foram analisados os tipos de relacionamento existentes entre os membros da família, o grau de satisfação das participantes com o apoio recebido pelos familiares e a rede social institucional na qual as participantes estão inseridas. O mapeamento das redes sociais significativas teve como objetivo analisar a função exercida pelo apoio social prestado às participantes pelos membros de suas redes, especialmente no que se refere ao enfrentamento do quadro psicopatológico.

\subsubsection{Categoria B1 - Aspectos estruturais da rede social significativa}

A categoria B1 engloba aspectos da estrutura das redes sociais das participantes, tais como: tamanho das redes, distribuição dos membros entre os quatro quadrantes do Mapa de Redes, o grau de conexão e distância entre esses membros e a caracterização biopsicossocial dos mesmos. 


\subsubsection{Subcategoria B1a - Tamanho da rede}

Sluzki (1997) relaciona o tamanho das redes com a possibilidade de acionamento dos membros em momentos de crise. Para que esse acionamento ocorra de forma efetiva, o referido autor propõe que as redes de tamanho médio são ideais, uma vez que as redes de tamanho pequeno são resultam em sobrecarga para os membros, que começam a evitar o contato com o indivíduo acometido para evitar a tensão gerada pelo quadro. As redes muito numerosas também foram caracterizadas como pouco efetivas, já que existe o risco da inafetividade causada pela suposição "alguém já deve estar cuidando do problema" (Sluzki, 1997, p. 46). Orlandi (2011) pontua que não há um consenso na literatura acerca do que pode ser considerada uma rede de tamanho grande, médio ou pequeno. Assim, baseando-se no modelo proposto pela referida autora, determinou-se que as redes de tamanho pequeno seriam aquelas nas quais foram representados até seis membros, de tamanho médio aquelas redes que apresentaram até 10 membros e, por fim, as redes que englobavam mais de 11 membros foram caracterizadas como grandes.

Vale ressaltar que algumas participantes mencionaram "pessoas", "primos", "tios" e/ou "amigas", sem atribuir um número específico de indivíduos, o que impossibilitou a quantificação exata de membros das redes sociais. Nos casos dessas participantes, foram atribuídos números aproximados de membros por redes, apenas com o objetivo de ilustrar o tamanho das redes. Dessa forma, evidenciou-se que nove participantes apresentaram redes classificadas como grandes: Fernanda (13 membros), Carolina (13 membros), Grazieli (20 membros), Maria (18 membros), Marina (22 membros), Juliana (23 membros), Estrelinha (14 membros), Ana (15 membros) e Amanda (16 membros). Três participantes apresentaram redes de tamanho médio: Bárbara (10 membros), Sofia (10 membros) e Sissi (sete membros). Nenhuma participante apresentou rede social de tamanho pequeno.

Apesar das redes sociais das participantes do presente estudo apresentarem uma quantidade média ou alta de membros, nota-se que boa parte desses membros não exercem papel significativo na vida das participantes. Trata-se de pessoas com quem elas têm pouco ou nenhum contato - por exemplo, "pessoas que encontra na rua ou no ônibus" (Carolina), ou "pessoas da igreja" (Maria) -, ou já tiveram contato em épocas anteriores, mas não têm atualmente. Sluzki (1997) define a rede social significativa como formada por pessoas que o indivíduo compreende como diferenciadas da "massa anônima da sociedade" (p. 42), ou seja, trata-se de pessoas com quem o indivíduo possui um vínculo. A partir do momento que 
esse vínculo é nomeado, ele traz consigo a noção de estabilidade e força. Nesse sentido, o fato de boa parte dos membros das redes sociais de algumas participantes não ter sido nomeada, e nem ter sido atribuída uma quantidade exata do número de membros, pode-se pensar que o potencial de apoio das redes encontra-se comprometido, uma vez que os membros que compõe essas redes parecem não exercer papel significativo na vida das participantes.

Em termos de intervenção profissional, Orlandi (2011) propõe que a identificação dos chamados membros "invisíveis" (p. 159) das redes - ou seja, aqueles membros que foram mencionados na organização das redes sociais, mas que não têm um papel efetivo no apoio social às participantes - e o acionamento desses membros como potenciais recursos para solicitação de ajuda pode ser considerada uma estratégia válida para a promoção da saúde e do bem estar de indivíduos acometidos por doenças crônicas, tais como o TA.

Como já mencionado anteriormente, a literatura específica das redes sociais propõe que redes muito numerosas são pouco efetivas no fornecimento de ajuda (Sluzki, 1997). No entanto, acredita-se que apenas será possível analisar a efetividade das redes sociais no enfrentamento do TA a partir da análise dos outros aspectos estruturais dessas redes e dos atributos dos vínculos das participantes com os membros que as compõem.

\subsubsection{Subcategoria B1b - Composição da rede}

A composição das redes sociais diz respeito à distribuição dos membros nos quadrantes do Mapa de Redes e, ao ser analisada em conjunto com o tamanho das redes (subcategoria B1a), possibilitou a reflexão acerca do apoio recebido pelas participantes, as fontes desse apoio e o vínculo da participante com os membros (Orlandi, 2011). Nesse sentido, a Figura 26 ilustra a composição das redes sociais das participantes do presente estudo, indicando a predominância de membros em determinados quadrantes. Vale ressaltar novamente que, em função da impossibilidade de quantificação exata do número de membros de cada rede social - devido às informações bastante vagas fornecidas pelas participantes na confecção dos instrumentos -, os números de membros que compõem as redes sociais são apenas aproximados. 


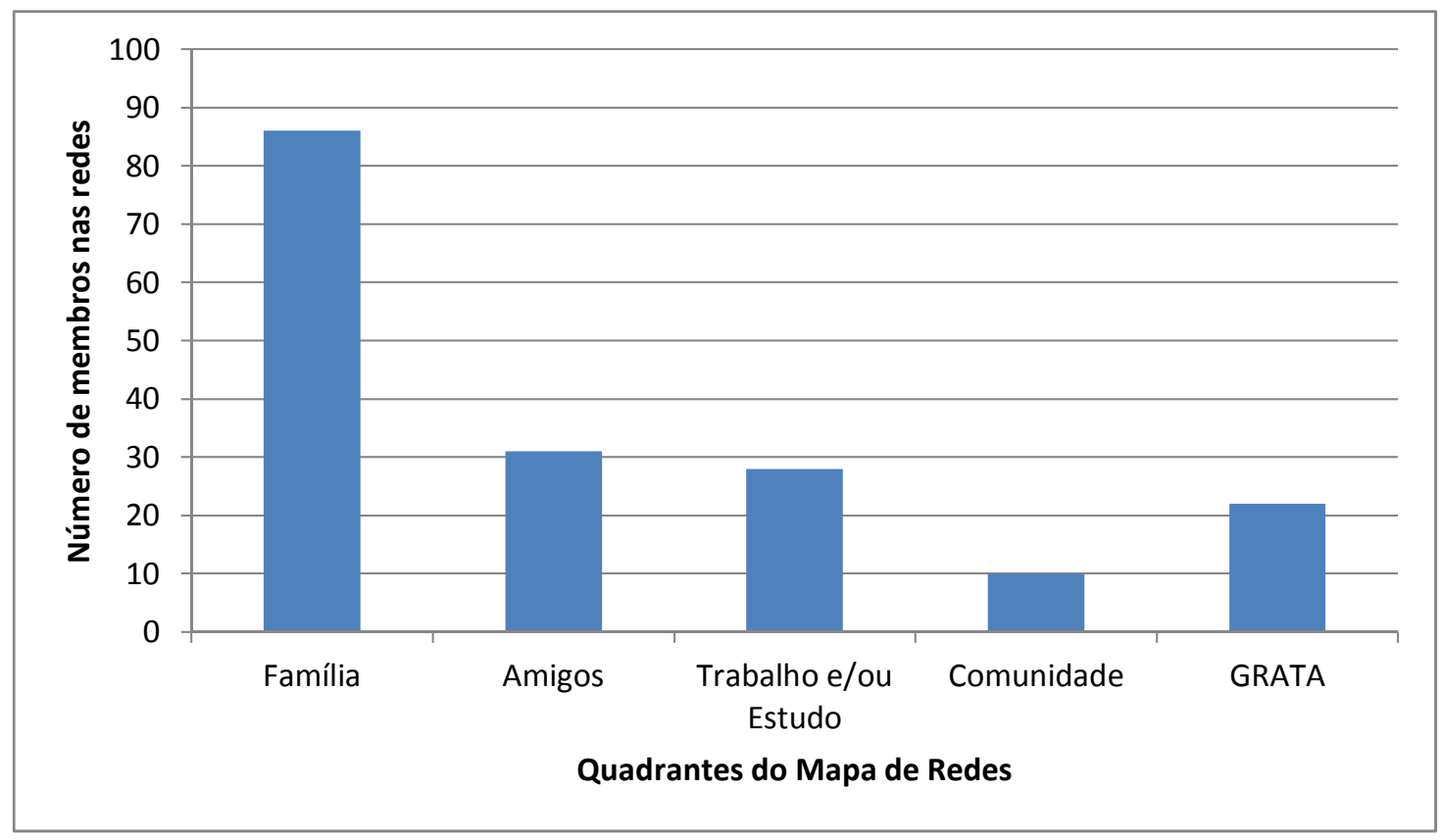

Figura 26. Composição das redes sociais das participantes

Considerando-se a distribuição dos membros nos Mapas de Redes, como demonstrado pela Figura 26, nota-se a predominância da rede social familiar. A soma de todos os membros de todos os Mapas de Redes confeccionados no presente estudo corresponde a aproximadamente 177 membros, dos quais por volta de 86 fazem parte do quadrante da Família. O quadrante de Trabalho e/ou Estudo e o de Amigos apresentaram números parecidos, sendo aproximadamente 28 e 31 membros, respectivamente. 0 quadrante da Comunidade apresentou aproximadamente 10 membros, e a parte do serviço de saúde (GRATA) apresentou 22 membros.

Dentre os familiares inseridos nos mapas de Redes, a mãe foi mencionada por todas as participantes. O pai foi mencionado por nove participantes, com exceção de Carolina e Marina, que relatam não possuir contato com este. Os irmãos foram mencionados por todas as participantes, com exceção de Bárbara. Sete participantes (Sofia, Bárbara, Grazieli, Ana, estrelinha, Juliana e Maria) mencionaram os primos e primas, cinco mencionaram os avós (Sofia, Bárbara, Estrelinha, Ana e Grazieli), quatro mencionaram tios (Maria, Juliana, Estrelinha e Sofia), três mencionaram sobrinhos (Fernanda, Marina e Juliana), duas mencionaram o namorado (Grazieli e Juliana) e os filhos (Carolina e Marina), e apenas uma participante mencionou o cunhado (Maria) e ex-cônjuge (Carolina). 
A predominância dos membros da família na configuração das redes sociais das participantes corrobora a literatura específica no que diz respeito à intensidade e frequência das relações. Bullock (2004) sugere que a família encontra-se no centro da influência interpessoal, apesar de seus múltiplos formatos e inúmeros significados, uma vez que pode ser considerada como um grupo de referência e um contexto social, onde ocorrem trocas mútuas. Além disso, a família também pode ser considerada como uma área de promoção de saúde, ao mesmo tempo em que pode se configurar como um espaço onde dinâmicas prejudiciais à saúde do indivíduo podem ocorrer. A autora também pontua que a família geralmente é a principal fonte de apoio e cuidado, pois seus componentes estão dispostos a empreender grandes sacrifícios para fornecer cuidados ao membro acometido.

A relação fundida e conflitual a mãe foi apresentada nos Genogramas de sete participantes (Juliana, Bárbara, Sofia, Maria, Ana, Amanda e Marina), enquanto que quatro apresentaram relação de aliança (Fernanda, Carolina, grazieli e Sissi) e apenas uma apresentou relação de superenvolvimento (Estrelinha). Esses dados corroboram a literatura, que propõe que a relação entre mãe e filha com TA geralmente se desenvolve a partir de um processo de indiferenciação, que implica na dificuldade de cada membro da dupla em se relacionar de forma individualizada (McGoldrick, Gerson, \& Petry, 2008). Nesse sentido, resta pouco espaço para diferenciação psíquica e reconhecimento da individualidade (Adami-Lauand, 2010). A relação de fusão e indiferenciação é comumente marcada pela ambivalência entre amor e ódio, uma vez que os membros da dupla se amam e desejam a proximidade um do outro, mas ao mesmo tempo tentam, sem sucesso, separar-se e individuar-se.

Levando-se em conta a dinâmica ambivalente vivenciada pelas mulheres com TA na relação com a figura materna, e considerando também que a mãe é o principal agente de cuidados à saúde (Gutierrez \& Minayo, 2008), é possível compreender como esse modo de vinculação tão conflituoso pode restar, paradoxalmente, como a principal fonte de apoio presente na vida das participantes.

A relação com o pai, por sua vez, foi apresentada como vulnerável para cinco participantes (Sofia, Bárbara, Sissi, Estrelinha e Grazieli). Trata-se de uma relação caracterizada por conflitos implícitos, mas que apresentam risco de se tornarem explícitos em condições adversas ou fases de transição (Wendt \& Crepaldi, 2008). Essas participantes relatam que já tiveram muitos conflitos com o pai, mas que atualmente possuem uma 
"relação de respeito" ou uma "relação boa". Maria e Juliana demonstraram possuir uma relação conflituosa com o pai, que foi caracterizado como autoritário pelas duas participantes, o que dificultava o estabelecimento de uma relação de proximidade. Os pais de Carolina, Marina e Fernanda são falecidos. Carolina relata ter sido "filha de uma ficada", indicando que seus pais nunca tiveram uma relação conjugal de fato, o que resultou em poucos encontros entre pai e filha. Fernanda não mencionou o pai durante a entrevista, apenas relatou o ano de falecimento do mesmo durante a construção do Genograma. O discurso de Juliana indicou a existência de uma relação emocionalmente distante com pai, sem muitos conflitos ou vínculos de intimidade.

Jones, Leung e Harris (2006) pontuam que a relação pai-filha exerce influência significativa sobre os sintomas de $\mathrm{TA}$, e que essa relação é marcada por rejeição e passividade paterna, e distância emocional entre pai e filha. Além disso, os autores também sugerem que os pais demonstram pouco afeto e exercem rígido controle sobre a filha acometida pelo quadro. Considerando tais disfunções na relação entre pai e filha com TA, pode-se pensar em uma insatisfação das filhas com o apoio fornecido pelos pais, uma vez que estes possuem dificuldades em demonstrar sentimentos de afeto pelas filhas e, consequentemente, de estabelecer uma relação íntima com as mesmas. Tais características do relacionamento entre pai e filha acometida por um TA parece acarretar em uma vulnerabilidade da relação, tornando-a facilmente sujeita a padecer frente a ocorrência de conflitos.

Quanto aos laços fraternos, seis participantes (Carolina, Sissi, Bárbara, Sofia, Amanda e Fernanda) relataram possuir relacionamentos distantes com pelos menos um (a) irmão (a). As participantes relatam a existência de conflitos fraternos, que culminam em um distanciamento dos irmãos. Dessa forma, os irmãos não são considerados fontes de apoio para as participantes, apesar de terem sido mencionados como membros integrantes das redes sociais de todas, exceto de Bárbara. Cinco participantes (Carolina, Fernanda, Maria, Sofia e Marina) também possuem relação harmônica com um dos irmãos. A ocorrência de conflitos explícitos com os irmãos surgiu no discurso de quatro participantes (Grazieli, Bárbara, Estrelinha e Fernanda). Por fim, apenas Ana e Amanda possuíam relação de aliança com os irmãos, que faziam parte de suas principais fontes de apoio.

Os relacionamentos fraternos marcados por conflitos e distanciamento corroboram a literatura especializada. Areemit, Katzman, Pinhas e Kaufman (2010) pontuam que os 
discursos de irmãos de mulheres acometidas por TA são marcados por contradições: por um lado, os irmãos expressam desejo de compreender o quadro e sentimentos de compaixão e preocupação pela irmã acometida; por outro lado, expressam também dificuldade na compreensão dos comportamentos obsessivos não relacionados ao quadro, aumento dos conflitos familiares, sentimento de perda e sacrifício, senso opressivo de responsabilidade pela irmã e uma sensação de onipresença do TA em todos os aspectos de suas vidas. Acredita-se que essa ambivalência vivenciada pelos irmãos de mulheres com TA possa ser uma das causas dos inúmeros conflitos que permeiam as relações fraternas, diminuindo o potencial de apoio dessas relações.

No que concerne aos outros familiares, como já foi mencionado anteriormente, as participantes inseriram primos (Sofia, Bárbara, Grazieli, Juliana, Estrelinha, Ana e Maria), tios (Maria, Juliana, Estrelinha e Sofia), avós (Sofia, Bárbara, Estrelinha, Ana e Grazieli), sobrinhos (Fernanda, Juliana e Marina), filhos (Carolina e Marina) e cunhado (Maria), em seus Mapas de Redes. No entanto, apesar de terem inserido os membros da família extensa em seus Mapas de Redes, a construção dos Genogramas possibilitou a visualização de que as participantes caracterizam as relações com esses membros como distantes e poucos frequentes. Nota-se, então, que tais familiares faziam parte da rede em decorrência dos laços de parentesco, sendo que tais vínculos foram naturalizados, não implicando em uma procura das participantes pela ajuda desses membros (Orlandi, 2011). A referida autora sugere que "a superficialidade do envolvimento das participantes" (p. 170) com os membros da família extensa dificultam a circulação das participantes em outros contextos, reduzindo a função suportiva da rede e intensificando a "carência de recursos pessoais para o estabelecimento de outros vínculos que transcendiam os que estavam postos, dados pela inserção familiar".

Ainda a respeito da naturalização dos vínculos familiares, nota-se que a percepção que as participantes têm do apoio social recebido pela rede social familiar foi considerada insatisfatória por três participantes (Bárbara, Sofia e Grazieli). Grazieli relata que o pai e o irmão consideram que o TA é "besteira", causando um sentimento de desamparo na participante, que gostaria de poder contar com a ajuda dos referidos familiares no enfrentamento do quadro. Sofia relata que têm recebido mais apoio dos pais desde o início do tratamento do GRATA, mas que ainda sente falta de um envolvimento maior deles e de sua irmã mais nova no tratamento. Bárbara, por sua vez, sente-se muito cobrada e 
ameaçada pelos familiares. Mesmo sabendo que as cobranças e ameaças são decorrentes de um desejo dos familiares de que ela melhore do quadro, a participante relata que vive com medo e não se sente apoiada.

Apenas Carolina, Marina e Maria foram casadas, sendo que esta última não teve filhos. A participante caracterizou o relacionamento que possuía com seu ex-marido como bastante conflituoso, uma vez que ele "não aceitava seu jeito, sua personalidade". O relacionamento durou três anos e o ex-marido não foi inserido no Mapa de Redes da participante. Carolina, por sua vez, teve dois relacionamentos conjugais, sendo que o primeiro durou dois anos e o segundo durou 13 anos. Ambos foram caracterizados pela participante como "bastante conturbados", ou seja, ocorriam muitas brigas entre o casal, principalmente decorrentes dos episódios de adultério por parte do ex-marido. Marina também define o casamento como conturbado, principalmente devido aos relacionamentos extraconjugais que o marido mantinha com várias mulheres, dentre elas uma prima da participante. A participante relatou que se sentia muito dependente do marido e tinha medo de ser abandonada, e só pôde se separar quando se envolveu com outro homem.

Carolina tem dois filhos, sendo um de cada casamento: ela relata que tinha o hábito de ser fisicamente violenta com o filho mais velho, pelo fato de "descontar" nele sua raiva e seus sentimentos agressivos. Quando teve o segundo filho, a participante relata que conseguia lidar melhor com sua agressividade e, portanto, não houve situações de violência física com este. Atualmente, o relacionamento de Carolina com o filho mais velho parece ser menos conflituoso, caracterizado como vulnerável. No entanto, apesar da relação com os filhos ser mais saudável atualmente, Carolina expressa sentimentos de angústia por criar dois filhos sozinha, o que faz com que a participante se sinta desamparada. Marina também teve dois filhos no casamento: uma filha de 11 anos de idade e um filho de três. A participante mencionou o filho poucas vezes, mas no discurso a respeito da filha ficou evidente uma relação bastante disfuncional: Marina expressa claramente o desejo de ter o corpo da filha, que é acompanhado de ódio do próprio corpo e, conseqüentemente, da filha.

Sluzki (1997) sugere que o casamento é um ritual que formaliza a consolidação de novas redes sociais dos membros do casal, já que costuma haver junção de elementos das redes anteriores de ambos. Quando acontece a separação, além da perda vincular central (perda do cônjuge), dá-se a dissolução de vários outros vínculos e projetos, inclusive de pessoas que até então eram figuras significativas na vida dos cônjuges. Além disso, novos 
vínculos são agregados à rede de cada indivíduo, pessoas que não conheceram o casal anterior e que, portanto, não incluem na sua percepção do sujeito a história de seu casamento, e nas quais o sujeito vê apenas a sua nova identidade de "separado, divorciado ou novamente solteiro" (Sluzki, 1997, p. 106).

O remanejamento da vida após a separação conjugal implica em inúmeras perdas nas redes sociais dos cônjuges: as pessoas que antes costumavam ser significativas na vida do sujeito passam a se afastar em função da separação do casal, abrindo espaço para que novas pessoas passem a fazer parte da rede pessoal. A perda desses vínculos, como pontuou Sluzki (1997), leva à reconfiguração das redes, ou seja, obriga o sujeito a realizar diversas mudanças em sua rotina e a dar conta de obrigações que antes podiam ser divididas com o cônjuge (por exemplo, a educação dos filhos).

No quadrante de Amigos, quatro participantes (Sissi, Fernanda, Ana e Bárbara) não inseriram ninguém. Entretanto, essas participantes inseriram amigas da faculdade (Bárbara, Ana e Sissi) e amigas do trabalho (Fernanda) no quadrante Trabalho e/ou Estudo. Carolina mencionou as "pessoas que encontra na rua e no ônibus" como parte da sua rede de amigos, caracterizando essas pessoas como Conhecidos. Sofia inseriu dois amigos no quadrante, sendo um com quem ela conversa frequentemente via internet, e uma amiga de onde a participante costumava trabalhar antes de ser afastada pelos problemas de saúde decorrentes do quadro de AN.

Durante a construção dos Mapas de Redes, as participantes relataram que não tinham amigos, e sim "colegas", ou seja, pessoas que viam com frequência, mas com quem conversavam superficialmente. Admitiram ter dificuldade em se aproximar das pessoas e estabelecer um vínculo sólido. Essas pessoas denominadas "colegas" não foram inseridas nos Mapas de Redes por escolha das próprias participantes, que caracterizavam o contato como tão superficial, que essas pessoas não faziam diferença em suas vidas a ponto de serem consideradas parte de suas redes sociais de amigos. Acredita-se que, por esse motivo, Sissi, Bárbara e Fernanda inseriram no círculo de Relações Sociais algumas amigas da faculdade e do trabalho, respectivamente, embora tenham frisado que se tratam de amigas com quem elas não têm um vínculo afetivo propriamente, mas com quem mantêm contato diário. 
Não, tenho alguns, assim, mas quando eu não digo assim, que, amigos... Colegas eu acho que você tem muitos, mas amigos, amigos, dizer que eu posso contar sempre com eles, eu acho que são muito poucos.

Maria, Grazieli, Amanda e Marina inseriram um número relativamente significativo de pessoas no quadrante de Amigos. Grazieli mencionou sete amigos, com quem possui relação íntima e frequente, sendo um deles o namorado. A participante relata que esses amigos e o namorado sabem do TA e fornecem apoio sempre que a participante necessita, estando sempre presentes, realizando atividades de lazer e conversando frequentemente. Maria, por sua vez, relata que tem "muitas pessoas" que poderia inserir no quadrante de Amigos, mas não soube atribuir uma quantia específica ao número de amigos. Além disso, a participante também incluiu duas pessoas em suas Relações Íntimas, pois se tratam de dois amigos com quem possui contato mais frequente e que são mais presentes em sua vida. Marina incluiu quatro vizinhas, a faxineira de uma das vizinhas e a filha dessa faxineira no quadrante dos Amigos, mas relatou que só sente que pode confiar na filha da faxineira, que também possui TA e, por isso, consegue compreender o que ela vivencia. A participante confidencia que as duas costumam ir juntas ao banheiro para vomitar.

Com exceção das participantes mencionadas no parágrafo anterior, nota-se uma escassez de amigos nas redes sociais das participantes. Essa escassez foi evidenciada por meio da análise dos Mapas de Redes, e pode ser compreendida como ilustração gráfica da dificuldade que as participantes apresentam em manter contato com as pessoas do meio em que vivem, restringindo assim o tamanho e a composição de suas redes sociais (Sluzki, 1997). Em consequência dessa restrição, a função da rede e o apoio social disponível para as participantes ficam comprometidos, uma vez que esses recursos estão relacionados com a qualidade das relações interpessoais (Moré, 2005).

Foi possível perceber que os quadrantes de Amigos e Trabalho e/ou Estudos misturavam-se, uma vez que algumas pessoas do Trabalho (Sofia) e do Estudo (Grazieli) foram consideradas amigas e, assim, foram inseridas no quadrante de Amigos, ou o contrário: essas pessoas permaneciam inseridas no quadrante Trabalho e/ou Estudo, mas eram nomeadas como "amigas" (Fernanda, Bárbara e Sissi). Carolina foi a única participante que realizou uma diferenciação entre amigos e pessoas do trabalho, inserindo sua patroa no quadrante de Trabalho e/ou Estudo. Foi possível perceber a existência de baixa representatividade do meio profissional na rede de apoio das participantes. Segundo Orlandi 
(2011), a não-inserção no mundo do trabalho impossibilita a realização de projetos profissionais, além de dificultar o estabelecimento de novos vínculos, acarretando na intensificação do isolamento social, uma vez que o trabalho pode ser considerado como fonte de contatos.

Quanto ao quadrante Comunidade, notou-se um predomínio de "pessoas da igreja", que foram mencionadas por quatro participantes (Sissi, Grazieli, Carolina e Maria). Maria caracterizou essas pessoas como íntimas, uma vez que se trata de pessoas de quem a participante recebe apoio e com quem mantém um relacionamento frequente. Ela também inseriu algumas pessoas da igreja nas Relações Sociais, denominando-se como pessoas com quem não mantém um vínculo de intimidade, mas que fazem parte de sua rede social. Sissi inseriu apenas uma amiga da igreja, com quem possui relação íntima. A participante relata que não tem contato com as outras pessoas que frequentam a igreja, pois considera as idas à igreja como uma atividade solitária. Carolina considera que as "pessoas da igreja" fazem parte de sua rede social, mas possui uma relação distante com elas, caracterizando-as como Conhecidos. A participante inseriu Deus nas suas Relações Íntimas da igreja, mencionando que "sempre resta ela e Deus". Por fim, Grazieli inseriu em suas Relações Sociais as crianças para quem dava aula na igreja, pois tinha um vínculo forte com essas crianças e as considerava fontes de apoio. Bárbara, Sofia e Fernanda relataram que não há pessoas da Comunidade que fazem parte de suas redes sociais.

O hábito de frequentar igreja pode ser considerado como uma forma alternativa de buscar apoio social, já que este não pode ser obtido por meio da relação com pessoas do ambiente de estudo ou de trabalho, ou de atividades de lazer. Bullock (2004) pontua que o apoio social pode ser proveniente do envolvimento em organizações comunitárias, uma vez que esse apoio possibilita níveis mais elevados de bem-estar psicológico e hábitos de vida saudáveis, tais como: diminuição dos sintomas de depressão, interrupção do tabagismo, aumento no cumprimento das recomendações de exames físicos, e controle do peso. Portanto, Bullock reforça que a igreja pode ser uma fonte importante de promoção de saúde, o que muitas vezes é negligenciado pelos profissionais da saúde, que tendem a ver essa atividade apenas como exercício da fé e da religiosidade.

Ana e Juliana também incluíram membros no quadrante da Comunidade, mas não se trataram de "pessoas da igreja". Ana incluiu a psicóloga e o professor de pilates, pessoas 
com quem a participante possui vínculo muito positivo. Juliana incluiu uma médium espírita de sua cidade, de quem ela recebe vários conselhos.

Por fim, o quadrante da Comunidade inclui uma parte que se refere ao serviço de saúde que as participantes frequentam, ou seja, o GRATA. Dez participantes (Bárbara, Fernanda, Sofia, Carolina, Grazieli, Marina, Juliana, Ana, Amanda e Maria) mencionaram os profissionais do GRATA como fontes de apoio significativas. Dentre esses profissionais, seis participantes (Sofia, Fernanda, Maria, Ana, Juliana e Grazieli) mencionaram as nutricionistas, cinco mencionaram a psiquiatra (Bárbara, Grazieli, Juliana, Amanda e Fernanda), duas mencionaram os psicólogos (Grazieli e Juliana) e Grazieli mencionou o médico nutrólogo. Além dos profissionais, as outras pacientes do GRATA também foram consideradas como fonte de apoio por cinco participantes (Bárbara, Maria, Carolina, Ana e Grazieli), uma vez que elas tinham a possibilidade de trocar experiências e informações entre si, o que exercia uma função de atenuar a angústia.

\subsubsection{Subcategoria B1c - Densidade}

Sluzki (1997) propõe que a densidade das redes diz respeito às conexões entre os membros, de forma independente da pessoa informante. A importância do estudo desta subcategoria é pautada no fato de que a articulação entre os membros da rede favorece o acionamento das fontes de apoio social no enfrentamento do quadro da pessoa acometida por uma doença grave (Moré, 2005). Dessa forma, procurou-se verificar as relações entre os membros da rede que oferecem apoio e o impacto dessas relações sobre o TA das participantes.

Baseando-se em Orlandi (2011), foram aplicados os seguintes critérios para caracterização dos graus de densidade das redes: números de pessoas que mantém contato entre si, qualidade da comunicação e efetividade da ajuda prestada. Vale ressaltar que o objetivo da presente pesquisa não engloba o aprofundamento acerca da densidade das redes. Assim, a análise dessa subcategoria foi realizada de maneira superficial, resultando no delineamento de grupos com baixa, média e alta densidade. Os grupos eram caracterizados com baixa densidade quando metade ou menos da metade dos membros tinham contato com um ou dois outros membros, havendo pouca intimidade entre eles. Já os grupos cuja metade ou mais da metade dos membros possuíam contato com, pelo menos, três outros membros e, no máximo, com cinco outros membros, foram caracterizados com densidade 
média. Por fim, os grupos com alta densidade incluíam as redes cuja metade ou mais da metade dos membros possuíam vínculo com, pelo menos, seis membros da rede, havendo a possibilidade da existência de relação entre todos os membros. A divisão dos grupos foi realizada de forma aproximada, uma vez que a quantificação do número de membros da rede não foi possível de ser realizada com exatidão na presente pesquisa.

Seis participantes (Sofia, Grazieli, Juliana, Estrelinha, Ana e Maria) apresentaram redes sociais com alta densidade, enquanto que quatro participantes (Bárbara, Marina, Amanda e Fernanda) apresentaram redes com densidade média e duas (Sissi e Carolina) apresentaram redes com baixa densidade.

Houve predominância de conexões relacionadas aos membros do quadrante da Família, principalmente desses membros entre si, nas redes de todas as participantes. Vale ressaltar que as relações entre os familiares se tratam de relações de parentesco que já estavam estabelecidas antes da ocorrência do TA no membro familiar acometido. Nesse sentido, ficou evidente que as interações entre os familiares não tinha como objetivo o fornecimento de apoio às participantes, e sim a manutenção de um contato que havia sido naturalizado em função das relações de parentesco (Orlandi, 2011).

Nos casos de Sofia, Fernanda e Bárbara, o TA "serviu para aproximar a família", ou seja, as participantes consideram que após a ocorrência do quadro, a família tornou-se mais unida, comunicando-se mais frequentemente, expressando preocupação pelo membro acometido e frequentando os grupos de apoio do GRATA. Sofia e Bárbara relatam que o grupo serviu para que os pais pudessem não apenas estar engajados no tratamento da filha, mas para que eles também pudessem aprender como lidar com o quadro de suas filhas de forma mais saudável. Esse engajamento dos pais entre si, com as próprias filhas e com o tratamento parece acarretar mudanças positivas na dinâmica familiar que, por sua vez, resulta na melhora do quadro psicopatológico (Santos, 2010). Fernanda relata que a aproximação maior se deu entre seus irmãos e sua mãe, que puderam conversar melhor e ressignificar o tipo de relação que mantinham entre si, de forma a colaborar com a melhora da participante.

As conexões entre os profissionais do GRATA e as famílias de sete participantes (Sofia, Bárbara, Sissi, Ana, Grazieli, Juliana e Maria) obtiveram destaque na análise da presente subcategoria, principalmente em função da participação dos familiares nos grupos de apoio, cuja importância é constantemente reforçada pelos profissionais. 
Excepcionalmente, nos casos de Fernanda, Marina e Carolina não há participação da família no tratamento, devido a dificuldades físicas da mãe de Fernanda (deficiência física decorrente de poliomielite) e ao fato da mãe de Carolina não ter conhecimento do TA. A mãe de Marina, assim como outros familiares de Carolina e Fernanda, se recusa a participar do tratamento, o que compromete a densidade da rede.

Vários autores (Dimitropoulos, et al., 2008; Hillege, Beale, \& McMaster, 2006; Souza \& Santos, 2006) propõem que a dinâmica familiar disfuncional, marcada por desintegração ou reagrupamento familiar, dificuldade de enfrentamento por parte dos pais, brigas e discussões, exerce influência significativa na precipitação e manutenção dos quadros de TA. Os relatos das participantes (Sofia, Bárbara, Sissi, Grazieli e Maria) acerca da melhora dos vínculos familiares após o início do tratamento no GRATA e da participação dos pais nos grupos de apoio podem ser considerados como consequência direta das conexões entre os profissionais e a família, já que a formação de uma aliança terapêutica, com papéis, direitos e deveres bem definidos fornecem subsídios para a melhora do quadro de TA (McMaster et al., 2008).

Considerando-se que as conexões identificadas na análise desta subcategoria existiam antes da ocorrência do TA nas participantes - exceto pelas conexões entre família e profissionais do GRATA -, Orlandi (2011) ressalta a importância dos profissionais da área valorizarem a importância da densidade da rede. É necessário que esses profissionais identifiquem e acionem os membros para que eles possam articular o apoio e favorecer a melhora do quadro do membro acometido pelo quadro. Acredita-se que esse acionamento dos membros das redes sociais seja um importante foco de atuação para os profissionais da área e uma estratégia significativa para o aprimoramento do tratamento dos TA.

\subsubsection{Subcategoria B1d - Dispersão}

Sluzki (1997) define a dispersão como sendo a distância geográfica entre os membros que compõem uma rede, tendo em vista que essa distância pode facilitar ou dificultar o acesso do membro acometido a esses membros, ou desses últimos ao membro acometido. Pode-se afirmar, então, que a dispersão diz respeito à eficácia da resposta da rede a situações de crise e às demandas de apoio (Orlandi, 2011). Nesse sentido, ainda que de forma breve, a análise da presente subcategoria buscou investigar a percepção que as participantes tinham da disponibilidade dos membros de suas redes sociais para o 
fornecimento de apoio, e quais as formas alternativas utilizadas para a manutenção do contato.

Evidenciou-se que os membros integrantes do quadrante da Família de todas as participantes, exceto Marina, apresentavam alta proximidade geográfica, uma vez que todos viviam na mesma cidade que as participantes, facilitando o contato e o fornecimento de ajuda nos momentos de necessidade. Nos casos de Sissi e Bárbara, a proximidade da família era maior antes do ingresso à universidade, quando as participantes passaram a morar sozinhas e longe da cidade de origem. No entanto, a frequência do contato com a família era alta para as duas participantes, que usavam o telefone e a internet como meios de comunicação diários. Nenhuma das duas participantes tinha carro, mas utilizavam meio de transporte público (ônibus) para visitar a família semanal ou quinzenalmente.

Em relação à proximidade dos membros dos outros quadrantes do Mapa de Redes, foi possível notar que os amigos e colegas de trabalho de sete participantes (Grazieli, Fernanda, Carolina, Marina, Estrelinha, Amanda e Maria) apresentavam alta proximidade geográfica entre si, com as participantes e com os membros do quadrante da Família das mesmas, uma vez que todos moram na mesma cidade. Sissi e Bárbara são exceções nesse caso, pois suas amigas - que envolvem apenas amigas da faculdade - e a orientadora de Bárbara moram em cidade distante da cidade de origem das participantes. No entanto, as amigas e a orientadora apresentam alta proximidade geográfica em relação às participantes, pois todas estão vinculadas à mesma universidade e, consequentemente, moram na mesma cidade.

Sofia foi a única participante que mencionou um amigo que mora em um Estado distante. A participante definiu esse amigo como alguém muito próximo e como uma fonte de apoio bastante significativa. Trata-se de um amigo que morava na mesma cidade que ela, e mudou-se ao ingressar na universidade. Os dois mantêm contato diário por meio da internet.

Por fim, observa-se a existência de alta proximidade geográfica entre os profissionais do GRATA e cinco participantes (Sissi, Bárbara, Sofia, Amanda e Grazieli), uma vez que estas residem na mesma cidade onde o serviço de saúde é instalado. Entretanto, os membros de suas redes sociais apresentam baixa proximidade geográfica em relação aos profissionais, e necessitam da utilização de transporte público para se locomover até o local do GRATA nos dias de retorno ambulatorial das participantes. Dentre os tipos de transporte público 
utilizados, foram inclusos ônibus, vans e ambulâncias, todos disponibilizados pelas prefeituras das respectivas cidades. Esses meios de transporte também são utilizados pelas participantes Fernanda, Carolina e Maria, e por suas famílias, que moram em cidades distantes e não possuem carro para se locomoverem.

A análise da presente subcategoria permitiu a ressalva da importância da família, pois além desta caracterizar a parte predominante da população das redes das participantes (como foi descrito na análise da subcategoria B1b), também configurou o quadrante com proximidade geográfica mais alta dos Mapas de Redes. Orlandi (2011) sugere que, mesmo sendo possível o fornecimento de apoio independentemente da proximidade geográfica das pessoas, a proximidade espacial configura-se como uma demanda em muitos casos, principalmente em situações de adoecimento. Nesse sentido, enfatiza-se a necessidade de que os membros da rede sejam aconselhados pelos profissionais de saúde acerca das possíveis formas de manutenção dos contatos, visando a oferta de ajuda e o bem estar das participantes.

\subsubsection{Subcategoria B1e - Homogeneidade/Heterogeneidade}

A presente subcategoria está relacionada aos aspectos sociodemográficos dos membros das redes sociais, ou seja, diz respeito à "idade, sexo, cultura e nível socioeconômico, com vantagens e inconvenientes em termos de identidade, reconhecimento de sinais de estresse, ativação e utilização" (Sluzki, 1997, p. 47). Nesse sentido, pretende-se investigar, de maneira breve, alguns aspectos sociais dos indivíduos inseridos nas redes das participantes deste estudo.

Tomando como base a tese de Orlandi (2011), serão analisados os seguintes aspectos: gênero, faixa etária, grau de instrução e vínculo religioso. A equipe de saúde foi excluída da análise por se tratar de um grupo institucionalizado, não sendo possível atribuir uma classificação segundo os aspectos sociais investigados. Deus, mencionado por Carolina, também foi excluído da análise. Vale ressaltar que as participantes forneciam informações bastante vagas acerca dos aspectos socioeconômicos e demográficos dos membros de suas redes. Dessa forma, os dados analisados na presente subcategoria se tratam de aproximações e estimativas.

No que concerne ao gênero dos membros que compuseram as redes das participantes, todas elas mencionaram membros de ambos os sexos (feminino e masculino) 
em suas redes sociais, sendo que todas citaram um número maior de mulheres do que de homens. O número total de membros do sexo feminino correspondia a aproximadamente 113, enquanto que o número de membros do sexo masculino era de aproximadamente 64 . Não foram mencionadas pelas participantes outras categorias além de feminino e masculino, tais como, por exemplo, transgênero. Nota-se, então, a predominância de membros do sexo feminino sobre os de sexo masculino, ainda que os números sejam apenas aproximados. Segundo Orlandi (2011) e Resende et al. (2006), as relações de gênero exercem força significativa no acionamento da rede, sendo comum que as principais fontes de ajuda sejam mulheres, uma vez que são estabelecidas relações de identificação.

Quanto à faixa etária dos membros das redes, estes foram divididos em: crianças (com idades entre 0 e 13 anos), adolescentes e jovens (entre 14 e 24 anos de idade), adultos (com idades entre 25 e 59 anos) e idosos (idades iguais ou acima de 60 anos). Tais classificações foram baseadas em Orlandi (2011). Apesar da maioria dos casos se tratar de uma estimativa de idades, ficou evidente que o número de adultos (aproximadamente 104) era significativamente maior do que o número de adolescentes e jovens (aproximadamente 42), idosos (15) e crianças (cinco).

As crianças inseridas nas redes foram os filhos de Carolina e Marina, que foram considerados como fontes de apoio social para as participantes. Grazieli citou as "crianças para quem dava aula na igreja" como fontes de apoio. No entanto, a participante não soube especificar o número de crianças, impossibilitando a quantificação das mesmas.

Quanto aos idosos, foram mencionados: pai (Maria e Juliana), mãe (Maria, Fernanda, Marina e Carolina), tios (Maria) e avós (Sofia, Grazieli, Ana, Estrelinha e Bárbara). Maria relata que, apesar de ter uma relação conflituosa com os pais, se sente apoiada por eles. No caso de Carolina, a mãe não sabe sobre o TA da filha, mas foi descrita como significativa fonte de apoio "para todas as outras coisas". Fernanda, por sua vez, expressa uma relação de intensa proximidade com a mãe, sendo esta a sua principal fonte de apoio. Tios e avós foram incluídos nas redes sociais de algumas participantes (Maria, Sofia, Grazieli e Bárbara) por se tratarem de membros da família, com quem a relação foi naturalizada. No entanto, esses membros não foram caracterizados como fontes de apoio significativas, com exceção da avó de Bárbara, com quem a participante possui uma relação de aliança e ajuda.

Quanto ao grau de instrução, nota-se a predominância de membros que completaram o ensino médio (aproximadamente 85 membros). O número de indivíduos que 
realizaram um curso de nível superior foi considerado relativamente baixo, correspondendo a, aproximadamente, 48 membros. Por volta de 12 membros apresentaram ensino superior incompleto, e 10 apresentaram ensino fundamental completo. Vale ressaltar que esses dados se tratam de estimativas, uma vez que as participantes forneciam informações um tanto imprecisas a respeito do grau de instrução dos membros de suas redes. Em termos de atuação profissional, foi possível encontrar as seguintes ocupações ou status profissionais: aposentados, donas de casa, pensionistas do INSS, motoristas, vigilante, vendedores, administrador, pintor, pedreiros, advogado, engenheiro civil, gráficos, proprietários de fábrica, agricultor, donos de banca de revistas, auxiliar em escola, nutricionista, psicóloga, enfermeira, estudantes, manicure, cozinheiras, caixas de supermercado, promotora de vendas e domésticas. Nota-se, então, que a ajuda prestada pelos membros da rede não tem relação com sua atuação profissional, exceto pelas duas profissionais da área da saúde.

Em relação aos vínculos religiosos, cinco participantes (Sissi, Maria, Carolina, Juliana e Grazieli) inseriram em suas redes indivíduos que estavam ligados à realização de atividades religiosas. Carolina e Maria inseriram "pessoas da igreja", Grazieli inseriu as "crianças para quem dava aula na igreja", Sissi mencionou uma "amiga da igreja" e Juliana, por sua vez, inseriu uma "médium" da igreja. Dessa forma, evidencia-se que as redes de Sissi, Carolina e Grazieli englobavam membros seguidores da religião evangélica, a rede de Juliana incluía uma pessoa da religião espírita e a rede de Maria incluía membros seguidores da religião presbiteriana, indicando forte influência dos vínculos religiosos sobre a configuração das redes sociais das participantes mencionadas. Considera-se que essa influência possui grande importância, uma vez que o apoio social pode ser proveniente do envolvimento em organizações comunitárias, e possibilita níveis mais elevados de bem estar psicológico e hábitos de vida saudáveis, tais como: diminuição dos sintomas de depressão, interrupção do tabagismo, aumento no cumprimento das recomendações de exames físicos, e controle do peso (Bullock, 2004). Portanto, a referida autora reforça que a igreja pode ser uma fonte importante de promoção de saúde, o que muitas vezes é negligenciado pelos profissionais da saúde, que tendem a ver essa atividade apenas como exercício da fé e da religiosidade.

Em suma, a análise dos aspectos estruturais das redes sociais das participantes do presente estudo demonstrou que estas eram amplas, mas com membros mal distribuídos entre os quadrantes dos Mapas de Redes. Além disso, as redes também apresentavam altos graus de densidade e baixos graus de dispersão. No entanto, uma análise mais acurada do 
fornecimento de apoio social e da satisfação das participantes com esse apoio depende da investigação acerca dos atributos do vínculo e dos tipos de funções da ajuda prestada pelos membros que configuram as redes sociais. As próximas categorias a serem analisadas irão tratar desses temas, de forma a realizar um aprofundamento acerca dos relacionamentos das participantes com os membros de suas redes e da percepção que elas possuem do apoio recebido.

\subsubsection{Categoria B2 - Atributos do vínculo}

A presente categoria de análise aborda os aspectos que caracterizam o padrão relacional de apoio existente entre as participantes e os membros que compõem suas redes sociais. Dessa forma, a categoria B2 inclui a história desses vínculos, o grau de intimidade e proximidade, a frequência do contato, a função predominante exercida e as funções ofertadas por cada membro da rede e, por fim, a reciprocidade nas relações analisadas.

\subsubsection{Subcategoria $B 2 a$ - História da relação}

Segundo Sluzki (1997), a "história da relação" diz respeito ao tempo em que a pessoa ajudada conhece os membros de sua rede e à experiência prévia de ativação desses vínculos. Considerando esta definição, procurou-se investigar, de maneira breve, a forma como se deu o desenvolvimento do vínculo entre as participantes e os membros de suas respectivas redes sociais. Assim, pretende-se analisar a formação dos vínculos de apoio, ou seja, a maneira pela qual tais membros das redes se tornaram fontes significativas de ajuda.

Como já mencionado anteriormente, a maioria dos membros das redes sociais das participantes fazia parte da rede familiar, ou seja, os vínculos foram desenvolvidos no próprio ambiente familiar. Trata-se de pais, filhos, irmãos, tios, primos, sobrinhos, avós, um namorado e um ex-cônjuge. Apesar de se tratarem de pessoas que já estavam presentes na vida das participantes no momento da ocorrência do TA, pode-se notar que alguns vínculos eram mais frágeis antes dessa ocorrência: Fernanda e Sofia relatam que tinham uma relação distanciada e conflituosa com uma de suas irmãs, mas essa relação foi modificada a partir da comunicação diagnóstica, quando as irmãs das participantes mencionadas passaram a manter maior proximidade e intimidade, procurando fornecer apoio às irmãs acometidas. 
A minha relação com ela melhorou depois que eu fiquei muito mal, assim... Porque ela que me socorreu, assim, que me internou, que ficou comigo todos os dias no hospital, então eu acho que mudou bastante, porque a gente sempre brigou muito, porque ela é do meio, eu sou a mais velha, então tinha aquela coisa de irmão do meio né, ciumenta demais e tudo, mas depois que eu fiquei mal ela se aproximou mais de mim.

As relações familiares das participantes eram permeadas por conflitos e discussões, mesmo antes da ocorrência do TA. Tais situações de conflito aconteciam em função de relacionamentos extraconjugais dos pais (Sissi e Sofia) ou do cônjuge (Carolina), separação dos pais (Amanda), violência por parte do pai (Sissi), sentimento de raiva em relação à mãe biológica (Marina), distanciamento dos pais e irmãos (Grazieli, Fernanda, Estrelinha, Ana, Sofia e Bárbara), dificuldade no estabelecimento de diálogo e relação íntima com os pais (Maria e Juliana) e incompreensão por parte dos pais (Maria e Bárbara). O distanciamento emocional entre os membros da rede familiar também foi mencionado pelas participantes, que relataram sentir falta de relações mais íntimas com os familiares, e de uma maior participação destes no tratamento. Entretanto, como já mencionado em categoria anterior (B1b), apesar das inúmeras situações de conflito descritas pelas participantes nas entrevistas, a família se configura como principal fonte de apoio. Esse dado também pode ser percebido na confecção dos Mapas de Rede, nos quais o quadrante da Família engloba o maior número de membros da rede.

Além dos familiares, também há indivíduos que fazem parte de outros contextos da vida das participantes. Foram incluídos amigos de infância ou de longa data, colegas de trabalho, da faculdade e pessoas da igreja. Algumas dessas pessoas - tais como os colegas de trabalho e da faculdade - passaram a fazer parte da rede social das participantes após a instalação do TA. Entretanto, o vínculo com tais pessoas não teve relação direta com a função de ajuda para lidar com as dificuldades decorrentes do quadro psicopatológico: apesar de terem sigo inseridas nos Mapas de Redes, as participantes relataram que muitas dessas pessoas não ofereciam apoio, ou nem mesmo sabiam da ocorrência do TA.

No que concerne às pessoas atreladas à vivência do TA das participantes, além dos familiares, evidencia-se o papel dos profissionais do serviço de saúde (GRATA) e algumas das outras pacientes que se encontram em seguimento no serviço. As nutricionistas foram mencionadas por seis participantes (Grazieli, Maria, Juliana, Sofia, Ana e Fernanda), que relatam que se sentem acolhidas pelas profissionais. Cinco participantes (Fernanda, Bárbara, 
Juliana, Amanda e Grazieli) também inseriram a psiquiatra do GRATA em suas redes sociais, caracterizando-a como fonte significativa de apoio. O nutrólogo e os psicólogos também foram mencionados por Grazieli e Marina. Ana inseriu a psicóloga que, apesar de não ser membro do GRATA, desempenha papel importante no fornecimento de apoio social. Quatro participantes (Bárbara, Grazieli, Maria, Ana e Carolina) relatam que possuem contato frequente com as pacientes do GRATA, uma vez que podem compartilhar experiências semelhantes e oferecer apoio mútuo.

Ainda acerca do contexto do serviço de saúde, vale ressaltar a importância do componente afetuoso nos relacionamentos das participantes com os profissionais desse meio (Orlandi, 2011). Eles foram caracterizados como atenciosos, pacientes e dedicados, que incentivavam o engajamento das participantes no tratamento, incentivavam o uso dos medicamentos receitados e ofereciam orientações em relação a possíveis questões e dúvidas que as participantes expressassem. Tais características tornavam os profissionais do GRATA pessoas significativas no enfrentamento do TA.

Em suma, nota-se que houve inserção de membros nas redes sociais de apenas duas participantes (Sissi e Bárbara) após a instalação do TA, sendo que esses membros envolvem amigas da faculdade e a orientadora (no caso de Bárbara). Entretanto, tais amigas não foram consideradas fontes de apoio, pois não há uma relação de intimidade e cumplicidade entre estas e as participantes. A orientadora de Bárbara foi considerada como fonte de ajuda, uma vez que foi caracterizada pela participante como alguém atenciosa e que incentivava a participação de Bárbara no tratamento. Nota-se que os membros que surgiram na vida das participantes do presente estudo após a ocorrência do TA são apenas aqueles vinculados ao GRATA, indicando uma dificuldade de vinculação, por parte das participantes, com pessoas que não estejam diretamente relacionadas ao universo do qual os indivíduos acometidos por um TA fazem parte (Orlandi, 2011). Esse dado corrobora a literatura específica no que concerne à dificuldade que as mulheres com TA possuem no contato com o mundo exterior (Peres \& Santos, 2006) e no estabelecimento de vínculos afetivos e de amizade (Cassin \& Von Ranson, 2005; Nilsson, Sundboom \& Häglöff, 2008).

\subsubsection{Subcategoria B2b - Intensidade do compromisso}

O grau de intimidade entre o indivíduo que recebe apoio e os membros de sua rede social foi denominado por Sluzki (1997) como "intensidade do compromisso". Considerando- 
se os três níveis de relação indicados pelo Mapa de Redes (relação íntima, social e conhecidos), os vínculos entre as participantes e os membros de suas redes foram classificados, no presente estudo, em três níveis de proximidade emocional (Orlandi, 2011), a saber: alto (que corresponde às relações íntimas), médio (correspondente às relações sociais) e baixo (que está relacionado aos conhecidos). A Figura 27 demonstra a distribuição, em números aproximados, dos membros das redes de todas as participantes nos quadrantes dos Mapas de Redes, de acordo com a intensidade do compromisso (Orlandi, 2011). Deus foi excluído da distribuição.

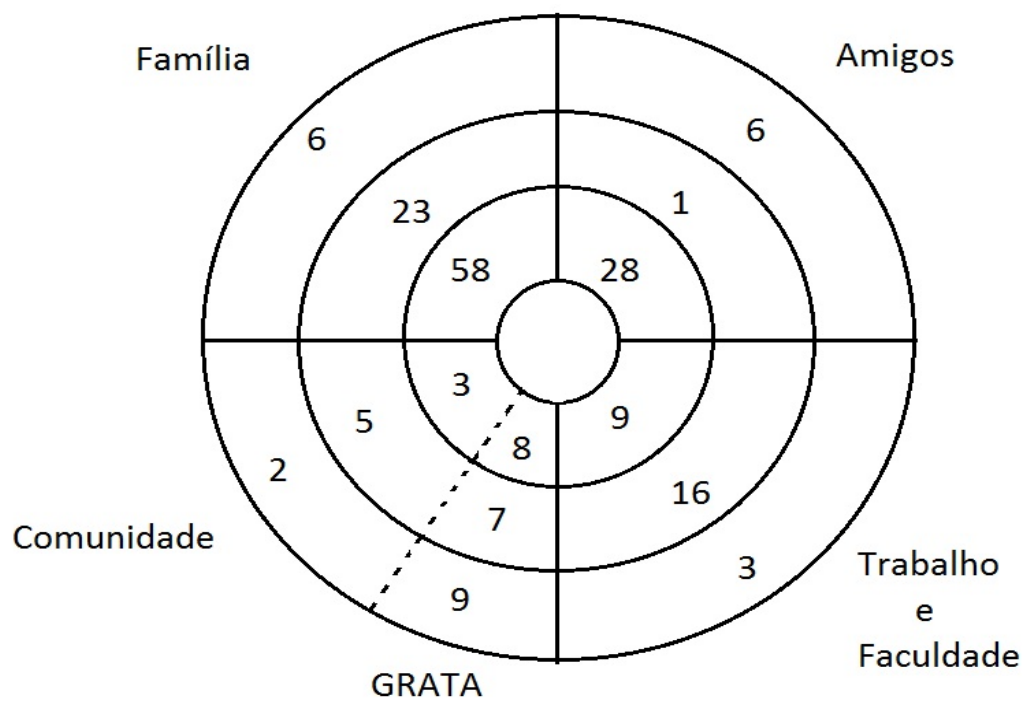

Figura 27. Intensidade do compromisso, segundo o Mapa de Redes de Sluzki (1997)

Como pode ser visualizado na Figura 27, a maior concentração de membros das redes sociais encontra-se no quadrante da Família, sendo que as relações íntimas apresentam a maior concentração de membros $(n=58)$, seguida das relações sociais $(n=23)$ e, por fim, dos conhecidos $(n=6)$. O quadrante da Comunidade apresentou os menores números de membros em todos os níveis de intensidade, seguido do quadrante do serviço de saúde. Vale ressaltar que os números representados na Figura 27 são aproximados, uma vez que a quantificação exata dos membros das redes sociais representadas no presente estudo foi impossibilitada, em função da dificuldade que as próprias participantes apresentaram em atribuir um número a esses membros. 
É possível notar que os primeiros níveis dos Mapas de Redes enquadravam o maior número de membros das redes, totalizando 106 indivíduos. Os segundos níveis (relações sociais) englobavam um total de 52 indivíduos e, por fim, os terceiros níveis totalizavam 26 membros. No entanto, nos primeiros níveis foram incluídas pessoas que, apesar do alto grau de intimidade relatado pelas participantes, não sabiam ou não falavam abertamente sobre o TA, ou possuíam relação conturbada e fragilizada com as mesmas. Esses dados geraram uma reflexão acerca do apoio social ofertado às participantes, uma vez que as condutas de evitação para falar a respeito do TA podem ser provenientes tanto delas próprias - cujas condutas de evitação são inerentes à sua personalidade (Cassin \& Von Ranson, 2005; Peres \& Santos, 2006) -, quanto dos membros de sua rede, que apresentam dificuldades para significar a experiência do TA (Souza, Santos, \& Scorsolini-Comin, 2009) e, consequentemente, não se sentem a vontade para tratar do assunto.

Apesar dos inúmeros conflitos existentes entre as participantes e as pessoas mais próximas de suas redes, seis participantes (Maria, Grazieli, Estrelinha, Ana, Fernanda e Sofia) mencionaram alguns poucos amigos e/ou amigas com quem mantinham uma relação bastante íntima, na qual podiam contar com o apoio e compreensão desses membros, principalmente nos momentos de maior necessidade, que incluíam a ajuda no enfrentamento do TA. Além disso, a relação das participantes com suas mães parece ser bastante estreita e intensa, sendo que a mãe foi caracterizada como principal fonte de apoio de nove participantes (Carolina, Sissi, Amanda, Marina, Estrelinha, Ana, Juliana, Fernanda e Grazieli), como já foi analisado em subcategoria anterior (B1b). Dessa forma, nota-se que a intensidade do compromisso nas relações familiares é maior no que diz respeito à relação entre mãe e filha. Segundo Spezcki e Vaz (2008), as mães tendem a vivenciar suas filhas com TA como menos separadas delas, devido a componentes narcisistas que prevalecem na relação da dupla, como identificação e simbiose. Os referidos autores ainda propõem que, no caso das mulheres com TA, algo se inverteu no processo de interação mãe-filha, prejudicando o vínculo entre elas e resultando na relação ambivalente de amor e ódio que é típica dos quadros de TA.

A análise da intensidade do compromisso nas relações das participantes do presente estudo evidenciou que tanto a dificuldade dos membros da rede em atribuir um significado e enfrentar o TA, quanto à dificuldade das próprias participantes em se vincularem às pessoas que compõem suas redes sociais significativas, apresentam resultados 
marcadamente negativos no grau de proximidade emocional que essas mulheres têm com seus amigos, familiares, colegas de trabalho e outras pessoas que fazem parte de seu meio ambiente. Considerando-se que as dificuldades surgem de ambos os lados (da participante e dos membros de suas redes), as relações tornam-se fragilizadas e vulneráveis, podendo ser desfeitas ou distanciadas frente a possíveis conflitos. Acredita-se que tal vulnerabilidade das relações compromete o potencial de apoio das redes sociais, podendo levar ao agravamento do quadro de TA, uma vez que o apoio social está diretamente relacionado com a melhora de transtornos crônicos (Bullock, 2004).

De forma a aprofundar a compreensão da efetividade do apoio social prestado pelos membros das redes sociais significativas das participantes, a seguir será analisada a frequência dos contatos.

\subsubsection{Subcategoria B2c - Frequência dos contatos}

A subcategoria em questão diz respeito à importância do contato frequente entre o sujeito acometido e os membros de suas redes sociais para a manutenção da intensidade desses contatos (Sluzki, 1997). Nos casos de distanciamento, a intensidade do vínculo pode ser verificada pela facilidade que esse apresenta para ser reativado. Nesse sentido, procurou-se realizar uma estimativa aproximada da frequência com que as participantes do presente estudo mantinham contato com os membros de suas redes, sendo que esse contato podia ocorrer pessoalmente, por meio do telefone ou via internet.

Considerando-se a dinamicidade da frequência dos contatos e a impossibilidade de se estabelecer um padrão cronológico exato, essa frequência foi investigada de forma aproximada. Assim, segundo Orlandi (2011), foram estabelecidos cinco intervalos de tempo, nos quais as estimativas das frequências de contatos foram enquadradas: alta (entre 365 e 50 vezes por ano), média (entre 49 e 12 vezes por ano), baixa (entre 11 e uma vez por ano), escassa (encontros que acontecem em períodos maiores que um ano) e perda do contato (impossibilidade de localizar a pessoa). A Figura 28 indica as estimativas de frequência de contatos entre as participantes e os membros de suas respectivas redes sociais significativas. 


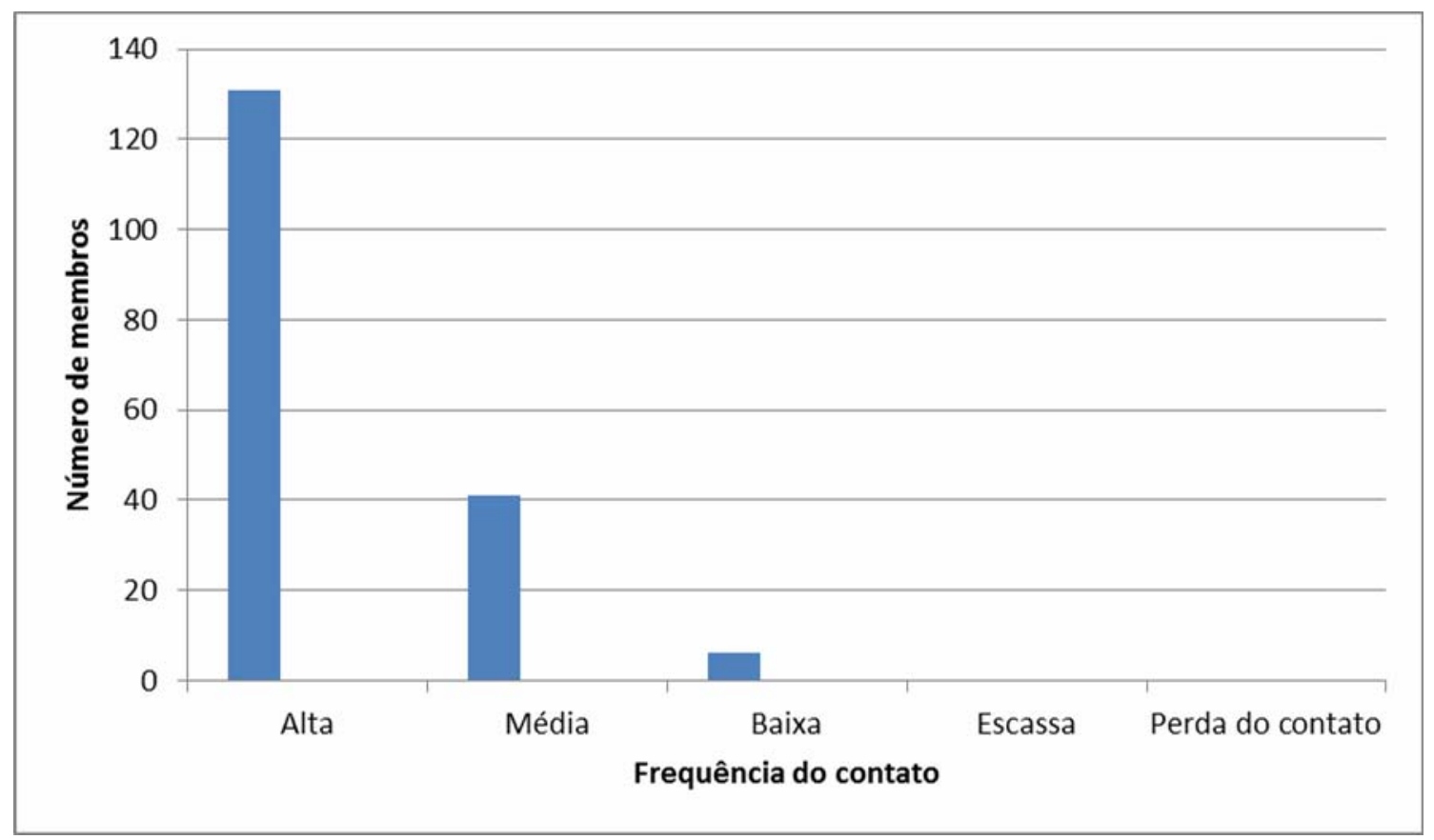

Figura 28. Estimativa da frequência dos contatos com os membros das redes

De acordo com a Figura 28, a maior parte dos contatos $(n=131)$ apresentava uma frequência alta de manutenção. Um número baixo de vínculos ( $n=41$ ) apresentou frequência média do contato, e um número menor ainda apresentou frequência baixa ( $\mathrm{n}=$ 6). Não houve vínculos com frequência escassa de contato, e nem perdas de contato.

Apesar da frequência alta de contatos com a maioria dos membros das redes sociais, nota-se que a qualidade do apoio recebido encontra-se comprometida na maioria desses vínculos, uma vez que todas as participantes relataram muitas situações de brigas e conflitos, principalmente entre os membros da família. Além disso, algumas pessoas com quem as participantes mantinham contato frequente não foram consideradas fontes significativas de apoio, pois se tratam se "amigas da faculdade" (Sissi e Bárbara) e "colegas de trabalho" (Carolina, Sissi, Maria e Fernanda), ou seja, são pessoas com quem as participantes mantinham contato diário, mas não possuíam relação de intimidade e não podiam contar com essas pessoas na ajuda para o enfrentamento do TA.

Levando-se em consideração os sentimentos de "solidão, tristeza e vazio", relatados pelas participantes e descritos na subcategoria $A 4 b$, e emparelhando-os com os dados encontrados na presente subcategoria (alta frequência de contato com a maioria dos membros das redes), é possível perceber que as situações de isolamento social ocorrem de forma independente da frequência com que as participantes mantêm contato com os 
membros de suas redes. Nesse sentido, em termos de intervenção por parte dos profissionais da área de TA, considera-se necessária a problematização da qualidade dos vínculos significativos, uma vez que a frequência alta dos contatos, de forma isolada, não determina a função de apoio e fornecimento de bem-estar às participantes. É importante que esses profissionais possam incluir os membros das redes significativas na assistência, de forma a melhorar a relação entre esses membros e as pacientes, otimizando e explorando o potencial de apoio das redes sociais. Tal aprimoramento na assistência teria como objetivo a melhoria da qualidade de vida das pacientes acometidas por TA, considerando-se que a qualidade de vida mantém estreita relação com a qualidade das relações sociais do indivíduo (Vaux, 1988).

O contato pessoal foi a forma mais utilizada pelas participantes para manter contato com os membros de suas redes, ainda que algumas tenham mencionado o contato via internet com amigos que moram em cidades distantes (Sofia) e com amigos da escola (Grazieli), que a participante vê e conversa pessoalmente todos os dias. Sofia também menciona a ocorrência de telefonemas frequentes com uma tia, de quem recebe bastante apoio para lidar com o TA. O contato telefônico frequente com familiares e uma amiga também foi relatado por Fernanda e Marina, mas em frequência menor do que o contato pessoal. Carolina foi a única participante que relatou ter mais contato telefônico do que pessoal com seus familiares (exceto sua mãe), com quem possui um relacionamento emocionalmente distante.

Em suma, considera-se que o discurso das participantes acerca da frequência dos contatos com os membros de suas redes não possibilitou, por si só, a percepção de que essa frequência colabora com o estreitamento dos laços (Orlandi, 2011). Como já mencionado, apesar da alta frequência de contato com a maioria dos membros das redes, evidenciou-se que a qualidade desses contatos era baixa, em termos de grau de envolvimento e fornecimento de apoio. Nesse sentido, segundo Orlandi (2011), acredita-se que "o mapeamento da periodicidade do contato deve ter em vista as modalidades de encontros que ocorreram ao longo do tempo" (p. 194), ou seja, para que seja realizada uma investigação mais aprofundada acerca dos vínculos entre as participantes e os membros de suas redes, é necessário investigar as funções exercidas por esses membros no contato com as participantes. 


\subsubsection{Subcategoria B2d - Função predominante do vínculo}

A função predominante de um vínculo, segundo Sluzki (1997), caracteriza a principal função desempenhada por cada membro da rede social significativa de um indivíduo. Tomando como base os tipos de funções de ajuda preconizados por Sluzki (1997), e o tipo de análise dessas funções de Orlandi (2011), as funções predominantes do vínculo consideradas no presente estudo foram categorizadas em: apoio emocional, guia cognitivo e de conselhos, companhia social, ajuda material e financeira. Trata-se das funções de ajuda mais citadas pelas participantes nas entrevistas. A Figura 29 ilustra a frequência em que cada tipo de função foi desempenhada pelos membros das redes sociais das participantes.

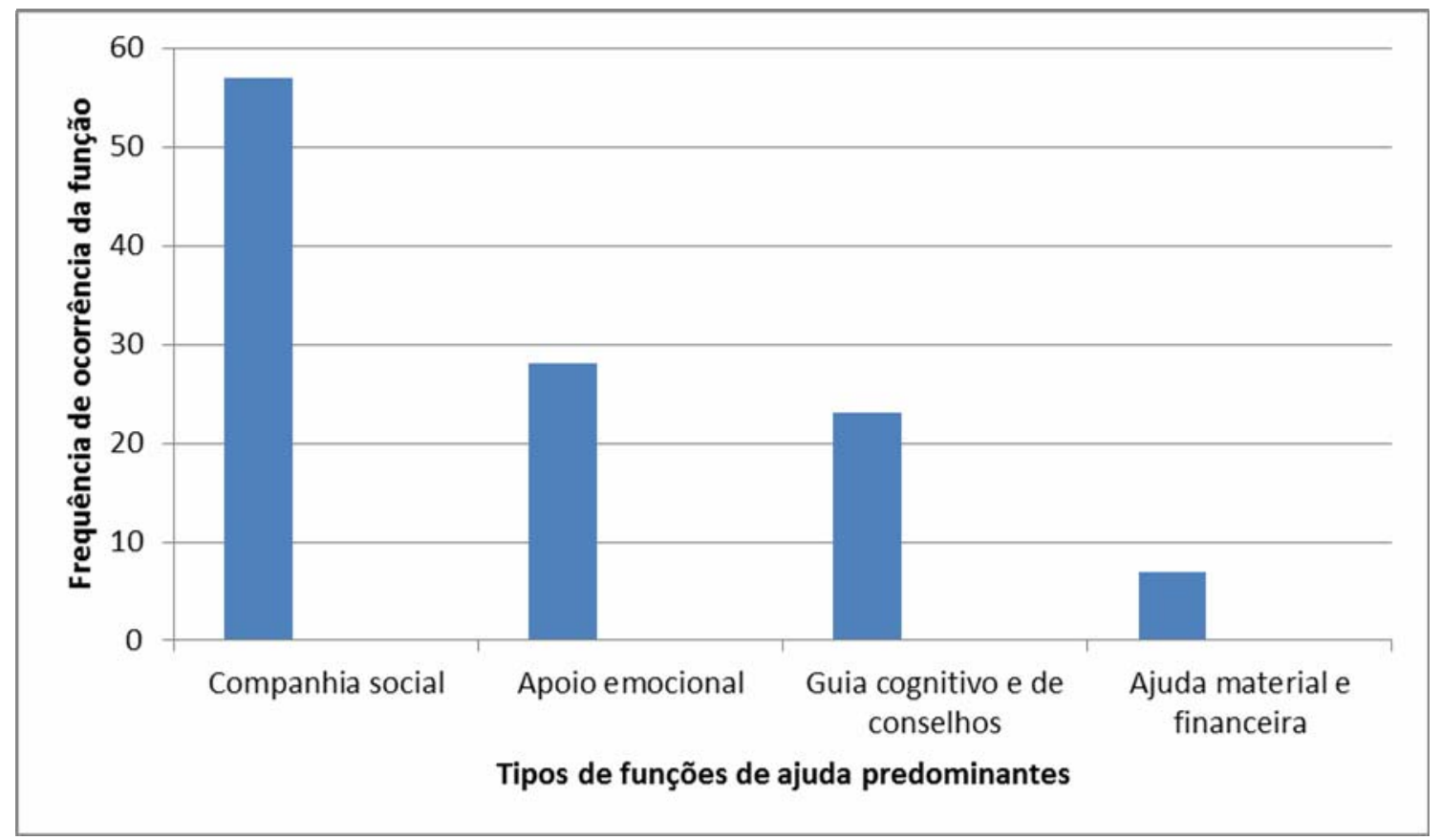

Figura 29. Funções predominantes nos vínculos com os membros das redes sociais das participantes

A função de companhia social foi o tipo de ajuda mais frequentemente desempenhado pelos membros das redes sociais significativas das participantes, tendo sido realizada predominantemente por 57 desses membros. Essa função diz respeito à companhia para realização de atividades diárias ou de lazer, ou simplesmente a "estar juntos" (Sluzki, 1997, p. 48), e foi desempenhada por amigas da faculdade (Sissi e Bárbara), da igreja (Sissi) e de outros âmbitos sociais (Maria e Amanda), colegas de trabalho (Sissi, Fernanda, Estrelinha, Amanda, Marina, Juliana e Maria), patroa (Carolina), namorado 
(Grazieli e Juliana), irmãos (Sissi, Carolina, Juliana, Sofia, Ana, Fernanda, Grazieli e Maria), tios (Sofia e Maria), primos (Bárbara, Sofia, Estrelinha, Juliana, Grazieli e Maria), cunhado (Maria), avós (Sofia e Ana), sobrinhos (Fernanda e Marina).

A função de apoio emocional, que envolve atitudes de "compreensão, simpatia, empatia, estímulo e apoio" (Sluzki, 1997, p. 49) foi exercida por aproximadamente 28 membros, predominantemente: mãe (Sissi, Carolina, Estrelinha, Ana, Marina, Amanda, Juliana, Bárbara, Sofia, Fernanda e Grazieli), irmãos (Carolina, Sofia, Amanda, Fernanda e Maria), filhos (Carolina e Marina), avó (Bárbara e Grazieli), sobrinho (Fernanda), amigos (Sofia), namorado e orientadora (Bárbara).

Os guias cognitivos e de conselhos são aquelas pessoas, segundo Sluzki (1997), com quem as participantes compartilham informações pessoais e de quem recebem conselhos e ajuda informativa. Nas redes sociais analisadas no presente estudo, 21 pessoas desempenharam predominantemente essa função, sendo que se tratavam de profissionais do GRATA (psicólogos, nutricionistas, psiquiatra e nutrólogo). Fernanda e Maria também inseriram as pacientes do GRATA nesta categoria, uma vez que trocavam conselhos e ajuda mútua. Ana incluiu a psicóloga com quem fazia terapia há muitos anos.

Por fim, a ajuda material e financeira foi desempenhada por sete membros das redes, principalmente pelo pai (Sissi, Bárbara, Sofia, estrelinha, Ana, Grazieli e Maria) e, no caso de Carolina, pelo ex-marido. Considerando-se o vínculo conturbado e/ou vulnerável existente entre a maioria das participantes e seus pais, nota-se que estes assumiram papel de provedores do lar, fornecendo ajuda material e financeira e não exercendo a função de apoio emocional, mantendo-se afastados do quadro psicopatológico das filhas.

\subsubsection{Subcategoria B2e - Multidimensionalidade do vínculo}

Além da função predominante do vínculo (analisada na subcategoria anterior), os membros das redes sociais das participantes também podem exercer outros tipos de funções de apoio. Essa versatilidade de funções que um mesmo membro pode realizar dentro de uma rede social (Orlandi, 2011) foi nomeada por Sluzki (1997) como multidimensionalidade do vínculo. Nesse sentido, buscou-se mapear as diversas funções de apoio que os membros das redes sociais significativas das participantes exercem, considerando os tipos de funções preconizados por Sluzki (1997). São elas: companhia social, apoio emocional, guia cognitivo e de conselhos, serviços e cuidados, ajuda material e 
financeira, regulação social e acesso a novos contatos. A Figura 30 apresenta o número de membros das redes que exercem cada tipo de função de ajuda, considerando que se trata de números aproximados.

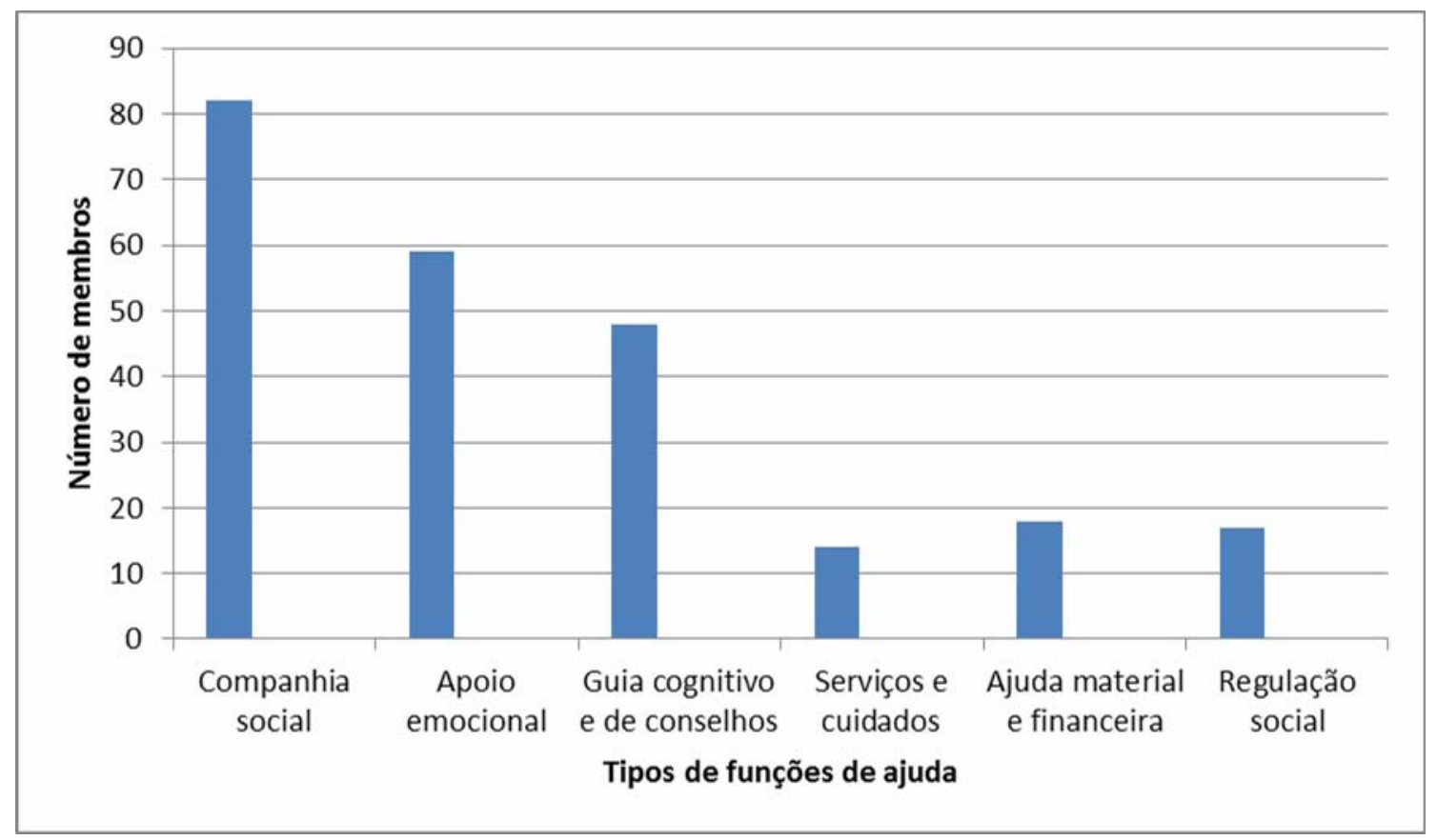

Figura 30. Distribuição dos tipos de ajuda exercida pelos membros das redes sociais das participantes

Segundo a Figura 30, nota-se que a função de companhia social recebeu maior destaque, tendo aproximadamente 82 membros exercido esse papel, seguido do apoio emocional (59 membros), guia cognitivo e de conselhos (48 membros), ajuda material e financeira (18 membros), regulação social (17 membros), serviços e cuidados (14 membros) e acesso a novos contatos (13 membros). Apesar das funções de regulação social e acesso a novos contatos terem surgido na multidimensionalidade dos vínculos, tais funções não foram mencionadas como o tipo de ajuda predominantemente desempenhada por nenhum membro das redes sociais. Todas as participantes possuíam redes com membros que exerciam as funções de companhia social, apoio emocional e ajuda material e financeira, apesar das diferenças em termos de frequência e qualidade da ajuda prestada.

Orlandi (2011) pontua a importância de relativizar o fornecimento de apoio, uma vez que algumas participantes pareciam não demandar certos tipos de ajuda, tais como conselhos (Carolina), serviços e cuidados (Carolina e Fernanda), regulação social (Carolina e 
Fernanda), ajuda material e financeira (Juliana e Marina) e acesso a novos contatos (Carolina, Sofia e Fernanda). Acredita-se que a demanda de ajuda esteja vinculada aos períodos de crise e os de adaptação, durante os quais se alteram os graus de autonomia e de fragilidade (Orlandi, 2011).

As mães podem ser consideradas como membros mais atuantes nas redes sociais das participantes do presente estudo, exercendo aproximadamente seis tipos de ajuda: companhia social, apoio emocional, guia cognitivo e de conselhos, serviços e cuidados e, em alguns casos, ajuda material e financeira. Dessa forma, é possível perceber que, apesar das relações familiares marcadas por conflitos e por excessivo controle materno (Bryant-Waugh \& Lask, 1995; Lane, 2002; McNamara \& Loveman, 1990), as mães constituem a principal fonte de apoio das participantes, conferindo um caráter ambivalente ao vínculo mãe-filha.

Os autores mencionados também sugerem o papel ausente desempenhado pelo pai, pontuando que este não costuma exercer a função de apoio social para a filha acometida por um TA. Os dados analisados nesta subcategoria corroboram esse dado, uma vez que os pais das participantes pareciam desempenhar apenas as funções de ajuda material e financeira, e serviços e cuidados. Ou seja, considera-se que os pais encontravam-se emocionalmente afastados das filhas, sendo responsáveis pelo sustento das mesmas, mas não pelo fornecimento de apoio social.

Sluzki (1997) propõe que a distribuição do cuidado parece ser mais saudável do que a centralização deste em apenas um ou poucos membros da rede social, já que essa centralização pode sobrecarregar os membros responsáveis pelo cuidado, comprometendo a efetividade da ajuda prestada (Orlandi, 2011). Ao levar-se em conta o baixo grau de acesso a novos contatos, assim como a figura da mãe como responsável pelo exercício de diversas funções, é possível ressaltar a importância de que os profissionais de saúde que trabalham na área dos TA realizem esforços para promoção de uma assistência sistêmica, na qual o cuidado possa ser distribuído entre os vários membros constituintes das redes sociais significativas.

\subsubsection{Subcategoria B2f - Reciprocidade}

Sluzki (1997) define a reciprocidade como "se você desempenha para uma pessoa o mesmo tipo de funções, ou funções equivalentes às que essa pessoa desempenha para você" (p. 58). Nesse sentido, tomando como base o modelo de análise de Orlandi (2011), 
foram identificadas as funções de ajuda exercidas pelas participantes deste estudo em relação aos membros de suas respectivas redes sociais. A Figura 31 apresenta a distribuição aproximada dos tipos de ajuda prestada, segundo as funções preconizadas por Sluzki (1997).

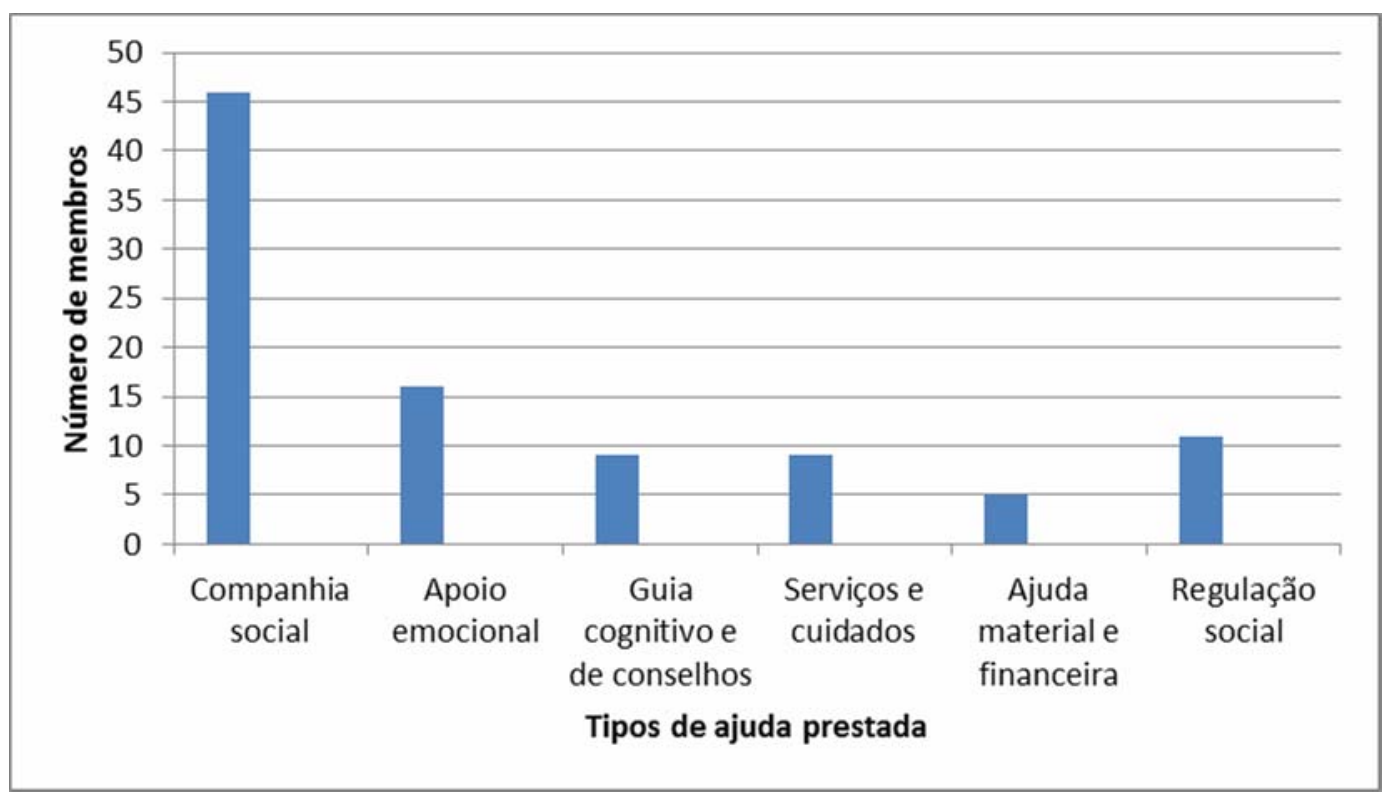

Figura 31. Funções de ajuda desempenhada pelas participantes aos membros de suas respectivas redes sociais significativas

Entre o total de 177 membros representados nas redes sociais significativas das participantes do presente estudo, aproximadamente 96 receberam algum tipo de ajuda proveniente das participantes, o que corresponde a $54,24 \%$ dos membros das redes sociais aqui representadas. A função de companhia social foi recebida por 46 membros, a de apoio emocional foi recebida por 16 , a de regulação social, por 11 , a de guia cognitivo e de conselhos, por nove, a de serviços e cuidados também foi recebida por nove membros e, por fim, a função de ajuda material e financeira foi recebida por cinco membros. A função de acesso a novos contatos não foi recebida por nenhum membro das redes sociais significativas das participantes. Nota-se, portanto, que a função de companhia social foi a mais destacada, assim como no apoio recebido pelas participantes, como foi discutido na subcategoria anterior (B2e - Multidimensionalidade).

A função de acesso a novos contatos parece estar comprometida em decorrência da dificuldade que mulheres com TA apresentam no estabelecimento de vínculos concretos com as pessoas de seu meio (Abreu \& Filho, 2004; Oliveira \& Santos, 2006; Peres \& Santos, 
2006). Essa dificuldade parece impedir que as participantes sirvam de elo e possibilitem o desenvolvimento de um vínculo entre duas ou mais pessoas, uma vez que o vínculo já existente é bastante frágil.

Os tipos de ajuda fornecida pelas participantes consistiam, principalmente, em eventos isolados, nos quais elas faziam companhia às amigas, ao namorado e a alguns familiares (por exemplo, primos) e frequentavam eventos sociais, tais como restaurantes, festas e comemorações familiares. Além disso, as participantes também exerciam as funções de apoio emocional e guia cognitivo, conversando e aconselhando esses membros quando estes se encontravam em situações de crise.

A função de serviços e cuidados era desempenhada apenas por quatro participantes: Carolina cuidava de seus dois filhos e de sua mãe, que tinha idade avançada; Marina cuidava de seus filhos; Juliana ajudava no cuidado aos sobrinhos pequenos; e Fernanda cuidava de seu sobrinho e de sua mãe, que, além da idade avançada, também apresentava deficiência física. Essas mesmas participantes (com exceção de Juliana) também foram as únicas que forneciam ajuda material e financeira aos membros mencionados (mãe e filhos), pois eram responsáveis pelos cuidados dos mesmos. Tais funções foram os únicos tipos de ajuda nos quais se notou uma continuidade do apoio, tendo sido iniciada em algum momento precoce da história da relação das participantes com os membros, e mantendo-se até o momento atual.

Foi possível notar que a função de regulação social foi bastante desempenhada pelas participantes em relação a seus próprios pais, evidenciando uma inversão de papéis: cinco participantes (Sissi, Bárbara, Sofia, Fernanda e Grazieli) relataram que precisavam constantemente relembrar seus pais de exercerem suas funções de cuidadores, principalmente no que dizia respeito à participação dos mesmos no tratamento. Esse dado corrobora a literatura, que traz que a desorganização dos papéis desempenhados pelos membros é comum dentre as famílias com um indivíduo acometido por um TA (Dallos \& Denford, 2008; McNamara \& Loveman, 1990).

Em suma, ao analisar o baixo número de membros apoiados pelas participantes, a pouca diversidade de recursos disponibilizados para a ajuda e a descontinuidade de apoio ao longo da história da relação - que, em muitos casos, foi limitado a eventos isolados -, considera-se que a reciprocidade da ajuda não foi expressiva. Levando-se em conta a existência de possíveis relações entre a reciprocidade e a qualidade da ajuda recebida pelas 
participantes (Orlandi, 2011), acredita-se que o potencial de apoio das redes sociais significativas se encontre comprometido, resultando em uma insatisfação por parte das participantes.

A seguir, serão analisados de forma mais detalhada os tipos de funções de ajuda, na categoria B3.

\subsubsection{Categoria B3 - Funções da rede}

A presente categoria refere-se ao "tipo de intercâmbio interpessoal entre os membros da rede" (Sluzki, 1997, p. 48), ou seja, diz respeito aos tipos de apoio que são prestados pelos membros da rede, e que podem favorecer ou não a qualidade de vida de um indivíduo. Pretende-se, então, destacar as situações que foram relatadas pelas participantes como apoio durante a vivência do TA, assim como as situações que foram relatadas como prejudiciais.

Para a análise da categoria B3, esta foi dividida em subcategorias, nomeadas segundo os tipos de funções da rede preconizadas por Sluzki (1997): companhia social, apoio emocional, guia cognitivo e de conselhos, acesso a novos contatos, regulação social e ajuda material e serviços. Seguindo o modelo de análise de Orlandi (2011), a última função mencionada (ajuda material e serviços) foi desmembrada em duas (ajuda material e financeira/ serviços e cuidados), uma vez que se identificou uma importante distinção entre ambas. A seguir, será analisada a primeira função da rede: companhia social.

\subsubsection{Subcategoria B3a - Companhia social}

A função de companhia social remete à realização de atividades em conjunto a outras pessoas, podendo consistir simplesmente em estar junto (Sluzki, 1997). No contexto deste estudo, essa função englobou a companhia para ficar em casa, conversar e participar de eventos sociais, tais como reuniões familiares, festas da faculdade e idas a restaurantes e ao cinema.

Os membros da rede que realizavam a função de companhia social eram: amigas da faculdade (Sissi e Bárbara), do trabalho (Maria, Juliana e Marina), do círculo de amigos do namorado (Estrelinha) e uma amiga da igreja (Sissi), vizinhas (Marina), irmãs e irmãos (Sissi, Carolina, Sofia, Fernanda, Grazieli, Ana, Marina, Amanda, Juliana e Maria), primos (Bárbara, Grazieli, Juliana, Estrelinha e Maria), sobrinhos (Fernanda, Marina e Juliana), tios (Sofia e 
Maria), cunhado (Maria), namorado (Grazieli e Juliana), patroa e algumas pacientes do GRATA (Carolina e Ana). Foi possível notar que as participantes não mantinham um vínculo de apoio significativo com a maioria dos membros mencionados, e nem uma convivência diária: evidenciou-se, inclusive, a existência de conflitos com alguns desses membros, principalmente com os irmãos e irmãs (Carolina, Fernanda, Grazieli, Sofia e Maria). No entanto, a presença desses membros na vida das participantes parece ter uma importância significativa, na medida em que eles foram inseridos nos Mapas de Redes e caracterizados como fornecedores de apoio, independentemente da existência ou não de conflitos.

Grazieli relatou uma convivência muito difícil e conflituosa com seu irmão, com quem costuma ter brigas frequentes, principalmente a respeito do TA: o irmão "acha que é frescura" da participante, e não fornece apoio. Sissi e Bárbara inseriram as amigas da faculdade nos Mapas de Rede, mas relataram não manter um vínculo muito próximo com as mesmas, restringindo a relação à realização de atividades acadêmicas e alguns eventos sociais da faculdade. Alguns familiares (avós, tios, primos, cunhado e sobrinhos) foram inseridos nos Mapas de Redes e caracterizados como companhias sociais pelo fato de que a presença desses familiares na vida das participantes parece ter um efeito benéfico para a qualidade de vida, ainda que não haja convivência frequente entre eles.

De modo geral, evidenciou-se que os membros das redes sociais que foram categorizados como companhia social não desempenham um papel significativo no apoio ao quadro psicopatológico e ao tratamento. Além disso, nota-se também que a existência desses membros nas redes sociais das participantes é marcada por ambivalências, uma vez que as relações, na maioria dos casos, são distantes e/ou conflituosas, mas também são fornecedoras de apoio apenas por estarem presentes. Acredita-se que essas ambivalências nas relações impedem que os membros mencionados constituam uma aliança segura (Vaux, 1988) para as participantes, podendo comprometer o apoio fornecido e impedindo a promoção do bemestar de forma plena, sempre alternando entre momentos de apoio e momentos de conflito. Vale ressaltar que essas ambivalências constituem o principal fator que diferencia a companhia social do apoio emocional (Sluzki, 1997), que será analisado a seguir.

\subsubsection{Subcategoria B3b - Apoio emocional}

Sluzki (1997) se refere ao apoio emocional como "intercâmbios que conotam uma atitude emocional positiva, clima de compreensão, simpatia, empatia, estímulo e apoio; é o 
poder contar com a ressonância emocional e a boa vontade do outro; é o tipo de função característica das amizades íntimas e das relações familiares próximas com um baixo nível de ambivalência" (p. 49). No presente estudo, o apoio emocional foi caracterizado por situações de consolo, acolhimento e conforto, promovidos em relação às dificuldades vivenciadas em decorrência do TA. Além disso, a disponibilidade para escuta empática, o fornecimento de apoio espiritual e a demonstração de afeto e preocupação também foram considerados fatores constituintes do apoio emocional.

Contrariamente ao que foi preconizado por Sluzki (1997) a respeito das relações ambivalentes, ou seja, aquelas que são marcadas pela alternância entre momentos de conflito e de afeto, a maioria das participantes do presente estudo caracterizaram a mãe como principal fonte de apoio. A literatura coloca que a relação entre mãe e filha com TA apresenta a ambivalência como uma característica bastante evidente (Adami-Lauand, 2010) e, no entanto, apesar dessa ambivalência, todas as participantes, com exceção de Maria, descreveram suas mães como fontes de apoio emocional. A mãe representava a figura mais presente na vida das participantes, para quem elas sempre se voltavam quando precisavam de consolo, atenção e conselhos. Durante o relato das participantes a respeito dessas situações, nota-se que nem sempre o consolo ou uma palavra empática era oferecida, pelo contrário, muitas vezes a mãe se isentava em proporcionar ajuda, ou culpabilizava a filha pela situação que ela estava vivenciando. Evidencia-se um comprometimento do apoio, na medida em que há vários momentos nos quais a mãe se resigna da ajuda e não colabora com a minimização do sofrimento (Orlandi, 2011).

Além da mãe, também foram descritos como fornecedores de apoio emocional: irmã (Carolina e Sofia), irmãos (Fernanda, Amanda e Maria), filhos (Carolina e Marina), sobrinho (Fernanda), avós (Bárbara e Grazieli), namorado e orientadora (Bárbara), pessoas da igreja (Maria) e crianças para quem dava aula na igreja (Grazieli). Os irmãos, avós, namorado e orientadora foram descritos como pessoas disponíveis para ouvir, acolher e aconselhar as participantes em momentos de crise, angústia e dúvida, e sempre se prontificavam a promover momentos alegres. Esses membros das redes mobilizavam a esperança, o que repercutia de forma positiva sobre a motivação para o tratamento, ainda que essa motivação fosse bastante inconstante.

O sobrinho de Fernanda, os filhos de Carolina e as crianças para quem Grazieli dava aula na igreja foram considerados fonte de apoio emocional, pois a presença dessas crianças 
na vida das participantes parece exercer uma função de promover o bem-estar, fazendo com quem elas se sintam bem. Acredita-se que a demonstração de afeto das crianças faça com que as participantes sintam-se amadas e importantes, resultando em um sentimento de identidade e pertencimento no mundo.

Durante a análise do apoio emocional, foi possível notar que poucos membros das redes sociais exerciam essa função, sendo a mãe a principal fornecedora de apoio, segundo o relato das participantes nas entrevistas. Considerando-se que a relação entre mãe e filha com TA é bastante conturbada, como já foi mencionado anteriormente, fica evidente a existência de laços sociais e afetivos vulneráveis, que acarretam brigas e conflitos frequentes e tendem para o rompimento.

\subsubsection{Subcategoria B3c - Guia cognitivo e de conselhos}

A presente subcategoria irá tratar das interações sociais que tem como objetivos principais a troca de informações pessoais ou sociais, o esclarecimento de expectativas e a oferta de modelos de papéis (Sluzki, 1997). Nesse sentido, de forma geral, a relação com os membros das redes inseridos nesta categoria englobam o compartilhamento de vivências, reflexões, recomendações, orientações e impressões acerca do estado de saúde das participantes, assim como a respeito de outros aspectos da vida, tais como as relações familiares e afetivas, hábitos prejudiciais à saúde e padrões de pensamento (Orlandi, 2011).

A análise desta subcategoria ilustrou a ausência de pessoas nas redes sociais com quem as participantes podem contar para realizar trocas de informações, oferecer orientações, despertar reflexões acerca das situações que tem vivenciado e para ajudá-las na quebra dos pensamentos rígidos acerca do peso e da alimentação. Evidenciou-se que as os membros da rede que desempenham essas funções de forma predominante são os profissionais do serviço de saúde, a saber: psiquiatra, nutricionistas, psicóloga e nutrólogo. Algumas pacientes do GRATA também foram inseridas na presente subcategoria, na medida em que as participantes realizam trocas de informações e conselhos com as outras pacientes do serviço.

As participantes relataram que mantêm um vínculo bastante positivo com os profissionais do GRATA, contando com estes quando precisam desabafar a respeito de alguma situação angustiante que tem vivenciado, ou quando precisam de ajuda para conseguir alívio dos sentimentos e pensamentos disfuncionais decorrentes do quadro 
psicopatológico. Os profissionais, além de elaborarem dietas, realizarem exames e avaliações clínicas, prescreverem medicamentos e oferecerem psicoterapia - cada um em sua modalidade específica -, também investigam outros aspectos da vida das pacientes, para além do TA: questionam a respeito da satisfação ou insatisfação com o corpo, do impacto negativo do TA sobre a vida, das relações familiares, entre outros, sempre buscando que as pacientes desenvolvam atitudes e pensamentos menos caóticos, melhorando a qualidade de vida. Acredita-se que essa aliança terapêutica entre profissionais e pacientes pode acarretar bons resultados sobre o tratamento e colaborar com a melhora do TA (McMaster et al., 2008). Além disso, a troca de informações e conselhos entre as pacientes do serviço, tanto nos grupos de apoio quanto na sala de espera da instituição hospitalar, parece desempenhar uma função de atenuação da angústia, uma vez que as participantes não se sentem sós e podem contar com pessoas que vivenciam dificuldades semelhantes.

Pode-se dizer que alguns outros membros das redes sociais também desempenham a função de guia cognitivo ou de conselhos, ainda que de forma esporádica. São eles: mãe (Sissi, Bárbara, Sofia, Grazieli, Marina, Juliana, estrelinha, Amanda e Maria), pai (Sissi), irmãos (Sofia, Fernanda, Amanda e Maria), avós (Bárbara, Ana e Grazieli), namorado (Bárbara), vizinhas (Marina) e amigos (Fernanda e Maria). Foi possível notar que a função principal dos membros aqui mencionados não era a de oferecer conselhos, orientações ou modelos a serem seguidos, uma vez que eles raramente eram procurados pelas participantes com esse intuito - para tanto, elas relataram procurar os profissionais do serviço de saúde. Porém, trata-se de pessoas com quem elas mantêm um vínculo e contato frequente, e que tem conhecimento a respeito da ocorrência do TA. Dessa forma, acreditase que o tipo de interação existente entre as participantes e os membros citados possibilita, de certa forma, a troca de informações e vivências e, consequentemente, a troca de conselhos e orientações.

Considera-se que a função de guia cognitivo e de conselhos, no contexto do presente estudo, apresentou relação com o engajamento das participantes no tratamento, pois, além de manterem um vínculo saudável e uma aliança terapêutica com os profissionais do serviço de saúde, também eram orientadas por outros membros das redes a respeito dos benefícios resultantes desse engajamento. Vale ressaltar que outras dificuldades comuns dentre as mulheres com TA entram em questão no que concerne à participação no tratamento, tais como: existência de comorbidades psiquiátricas, medo de serem estigmatizadas, 
preconceito em relação aos efeitos colaterais dos medicamentos prescritos, entre outros (Rodríguez, Hernández, \& Bouly, 2000; Stewart, Keel, \& Schiavo, 2006). Dessa forma, não se pode afirmar que a existência de membros que desempenham a função de guia cognitivo ou de conselhos seja determinante no engajamento das pacientes no tratamento.

\subsubsection{Subcategoria B3d - Serviços e cuidados}

Sluzki (1997) define a função de serviços como a ajuda física ou o apoio baseado em orientações fornecidas por especialistas da área da saúde. Baseando-se no modelo de análise de Orlandi (2011), essa função foi redefinida como "serviços e cuidados", e englobou a colaboração ofertada para o acompanhamento nos atendimentos médicos, o monitoramento do uso dos medicamentos e da participação no tratamento, e a atenção dada por familiares, principalmente em relação ao enfrentamento do TA.

Os pais e as mães foram os únicos membros das redes sociais de nove participantes (Sissi, Bárbara, Sofia, Grazieli, Juliana, estrelinha, Ana, Amanda e Maria) inseridos na subcategoria de serviços e cuidados. Bárbara, Sofia e Maria relatam que houve uma insistência por parte dos pais para que elas procurassem tratamento para as dificuldades alimentares e a insatisfação com o corpo, e essa insistência permanece até os dias atuais, nos quais os pais buscam persuadir as filhas a não faltarem dos atendimentos e a seguirem as recomendações fornecidas pelos profissionais. Sissi e Grazieli procuraram o GRATA de forma espontânea, sem a interferência dos pais. Entretanto, relatam que os pais (no caso de Grazieli, apenas a mãe) também insistem para que as filhas sigam o tratamento à risca. Esses dados evidenciam, assim como já foi apontado anteriormente, a primazia da rede de apoio familiar no cuidado às mulheres com TA, independentemente da existência de discussões e conflitos frequentes (Bullock, 2004).

Nos discursos de Carolina e Fernanda não foi possível identificar membros da rede que desempenhassem a função em questão na presente subcategoria. Acredita-se que tais participantes apresentem dificuldades em procurar ajuda, principalmente da mãe, por terem medo de se tornarem um "peso". Carolina relata:

Porque a minha mãe já tem problema demais, tadinha. Minha mãe tem 70 anos. Minha mãe, outro dia, só de estar lá sentada na sala assistindo TV, ela levantou e falou: "Ai minha cabeça tá doendo", aí eu fui medir a pressão dela e estava 25 por 20. Você imagina ela vindo aqui no hospital e ficar sentada aqui a tarde toda... 
Fernanda, por sua vez, relata que a mãe tem idade avançada e possui uma deficiência física que dificulta sua locomoção, impedindo que ela realize a função de cuidadora, no sentido de acompanhar a filha ao serviço de saúde, monitorar o uso de medicamentos, entre outros.

A análise dos relatos das participantes evidenciou que a iniciativa dos pais de procurarem o serviço de saúde para as filhas, assim como o monitoramento da participação no tratamento e do seguimento das recomendações médicas, configuraram formas significativas de cuidado. Considera-se, então, que as redes sociais atuaram no processo de cuidado e enfrentamento do TA (Sluzki, 1997), e que esse cuidado pode possibilitar maior eficácia do tratamento.

\subsubsection{Subcategoria B3e - Ajuda material e financeira}

Orlandi (2011) caracterizou esse tipo de ajuda como "o empréstimo e/ou doação de dinheiro, comida e/ou objetos" (p. 212). Considerando que a maioria das participantes deste estudo (Sissi, Bárbara, Sofia, Grazieli, Ana, Estrelinha, Amanda e Maria) dependia dos pais para o seu sustento, notou-se uma predominância dos pais, principalmente os genitores do sexo masculino, na subcategoria em questão.

Sissi e Maria trabalhavam e tinham uma renda mensal significativa, mas ainda contavam com a ajuda dos pais para seu sustento: Sissi morava sozinha e conseguia viver com seu salário, mas eventualmente contava com a ajuda financeira do pai, e Maria, por sua vez, morava na casa dos pais, que arcavam com todas as contas, sendo que o salário da participante era reservado para gastos e aquisições pessoais. Grazieli também trabalhava, mas tinha uma renda mensal baixa, que a mantinha financeiramente dependente dos pais.

Sofia havia sido afastada do trabalho por ordens médicas, devido às complicações clínicas decorrentes do TA. Dessa forma, a participante morava com os pais e estes arcavam com todas as contas e eventuais gastos da filha. Bárbara, por sua vez, havia se mudado da casa dos pais para cursar a universidade. Morava em uma cidade distante da família e não possuía emprego, dependendo do dinheiro que seus pais forneciam todo mês.

Nos casos de Fernanda e Carolina, a renda mensal proveniente do trabalho de ambas era o suficiente para mantê-las. Entretanto, Carolina também contava com a ajuda financeira do ex-marido para o sustento dos filhos, e Fernanda contava com a ajuda dos irmãos para o sustento de sua mãe e seus sobrinhos, que moravam na casa com ela. 


\subsubsection{Subcategoria B3f - Regulação social}

A regulação social - também denominada como "controle social" por Sluzki (1997) diz respeito às "interações que lembrar e reafirmam responsabilidades e papéis, neutralizam os desvios de comportamento que se afastam das expectativas coletivas, permitem uma dissipação da frustração e da violência, e favorecem a resolução de conflitos" (p. 50). Não foram mapeadas relações que apresentassem a regulação social como função predominante do vínculo. Porém, foram identificados alguns membros das redes sociais que desempenhavam essa função de forma esporádica. Foram eles: mãe (Sissi, Sofia, Bárbara e Grazieli), pai (Bárbara, Juliana e Grazieli), irmãos (Bárbara, Amanda e Maria), namorado (Bárbara), vizinhas (Marina) e pessoas da igreja (Maria).

Os membros mencionados realizavam esforços no sentido de atenuar os comportamentos - alimentares, purgativos e também sociais - disfuncionais das participantes. Os discursos foram bastante convergentes no que concerne ao fato de que tais membros buscavam relembrar às participantes os resultados negativos que a má alimentação trazia para suas vidas, assim como os rituais compensatórios (por exemplo, vômitos e uso abusivo de laxantes). O namorado de Bárbara procurava pontuar os aspectos negativos do TA, que prejudicavam sua vida social, impedindo que ela o acompanhasse a bares e restaurantes.

A vida social das filhas também surgiu como uma preocupação constante das mães, que insistiam para que as filhas tivessem "uma vida normal", ou seja, saíssem com os amigos e se divertissem. No entanto, as participantes também relatavam uma ambivalência nas atitudes de suas mães, pois ao mesmo tempo em que elas gostariam que suas filhas tivessem "uma vida normal", também demonstravam muita preocupação com seu estado de saúde e ficavam apreensivas quando elas manifestavam desejo de buscar essa "normalidade", ou seja, quando saíam, viajavam, entre outros.

\subsubsection{Subcategoria B3g - Acesso a novos contatos}

A presente subcategoria refere-se aos relacionamentos que abrem portas para que haja conexão entre o indivíduo e outras pessoas, fazendo com que haja a circulação de novos sujeitos em seu meio e ampliando sua rede social (Sluzki, 1997). Essa função foi desempenhada predominantemente por amigos e amigas (Sissi, Bárbara, Marina, Grazieli e Maria), pelos irmãos (Amanda) e pelo namorado (Bárbara, Estrelinha e Grazieli). 
No entanto, as participantes não relataram pessoas que passaram a ter um papel significativo em suas vidas após terem sido apresentadas por membros de suas redes sociais: o acesso a novas pessoas tratou-se de contatos que aconteceram de forma espontânea, em situações sociais nas quais as participantes acompanhavam seus amigos ou seu namorado, e não houve formação de vínculo. Nota-se, então, que esses contatos foram realizados sem a intenção de promover uma ampliação das redes sociais, não constituindo fontes de apoio.

De forma geral, a análise das funções da rede evidenciou alguns aspectos que parecem comprometer o potencial de apoio das redes sociais significativas das participantes. O número de membros que compõem as redes, apesar de ser alto, não implica em uma atuação efetiva desses membros na ajuda para o enfrentamento do quadro de TA. As relações são marcadas por muita ambivalência, ou seja, por uma alternância entre momentos de demonstração de afeto, carinho e preocupação, e momentos de discussão, brigas e conflitos. Essa ambivalência parece impedir que as participantes tenham uma percepção positiva do apoio social e emocional recebido, o que corrobora a literatura (Sluzki, 1997).

Entretanto, foi possível perceber as iniciativas dos pais da maioria das participantes em procurar tratamento para as filhas e/ou insistirem para que estas sigam à risca as recomendações fornecidas pelos profissionais do serviço de saúde. Além disso, também nota-se a existência de uma aliança terapêutica entre as participantes e os esses profissionais. Essas evidências parecem facilitar o engajamento das mesmas no tratamento, possibilitando um bom prognóstico do quadro psicopatológico.

A categoria a ser analisada em seguida irá tratar da forma como as redes sociais significativas encontram-se configuradas no momento atual, e o modo como as participantes se inserem nessas redes.

\subsubsection{Categoria B4 - Organização das redes sociais significativas e caracterização da} inserção das participantes

Neste momento do presente estudo, procurou-se mapear a configuração atual das redes sociais, ou seja, realizar uma análise dos membros mais significativos das redes, aqueles com quem as participantes têm maior convivência e que são descritos como principais fontes de apoio. Em contrapartida, também foram analisados os conflitos e as relações conturbadas, uma vez que estas também exercem impactos sobre o quadro de TA 
(Sluzki, 1997). Por fim, a categoria em questão também engloba o papel desempenhado pelas próprias participantes dentro das redes sociais significativas.

Nesse sentido, as subcategorias a serem analisadas a seguir serão descritas como: redes sociais de amigos, vida social, família como rede social mais significativa, distância emocional entre os familiares, maior convivência com a família, dificuldade das pessoas das redes em lidar com o TA.

\subsubsection{Subcategoria B4a - Redes sociais de amigos}

$\mathrm{O}$ isolamento social foi um dado convergente no discurso de sete participantes (Bárbara, Carolina, Sofia, Juliana, Amanda, Sissi e Ana). Diz respeito ao incômodo vivenciado ao se relacionar com outras pessoas, e a consequente evitação de criar vínculos e frequentar lugares públicos. Sissi relata que essa evitação decorre da certeza de que iria vomitar no lugar em que estivesse, e por isso preferia ficar em casa. Bárbara, por sua vez, não gosta de "tá no meio de muita gente", pois acredita que as pessoas reparam muito nela, em sua aparência. Considera que possui "mania de perseguição". Carolina apresenta um discurso muito parecido com o de Bárbara, ao relatar que "não gosta de viver no meio das pessoas, num monte de pessoas aglomeradas, prefere ficar só". Juliana relata que havia desenvolvido "um modo de agir, um modo de viver, um modo de ser, que mantinha as pessoas sempre longe", pois "tinha a autoestima muito baixa e não se gostava".

Sofia relata que o isolamento sempre foi uma constante em sua vida, mas que foi intensificado com o advento do TA.

[...] mas antes eu já era mais fechada, mais isolada... Sempre fui de ficar mais em um canto, não consigo me lembrar de uma época onde eu fui de ficar em uma turminha assim, eu não lembro. Eu sempre fui de ficar mais isolada, mais no meu canto, e isso também com a comida, assim...

No entanto, apesar de se isolarem do meio social, Sissi e Bárbara relataram um desejo de estarem integradas à rede. Ambas mencionam que se sentem muito sozinhas, e gostariam de ter mais proximidade com os amigos. Nota-se a existência de uma ambivalência, pois ao mesmo tempo em que desejam estarem inseridas na rede, se mantêm fora dela. 
Ah, sabe assim... Pô, é chato, sabe? Tá todo mundo junto, assim... Você quer ficar sozinha? Você não quer ficar sozinha, sabe... Daí... Às vezes, eu até dava umas indiretas, assim... Mas eu não tenho coragem de chegar e falar [...]. Porque eu acho que quando você quer a companhia da pessoa, você chama, não precisa ficar a pessoa se oferecendo.

Oito participantes (Bárbara, Carolina, Marina, Amanda, Sissi, Ana, Estrelinha e Grazieli) demonstraram realizar uma distinção entre "colegas" e "amigos", definindo como colegas aquelas pessoas com quem elas convivem, mas não têm uma relação de intimidade, ou seja, não compartilham eventos e sentimentos significativos de suas vidas. Nesse sentido, elas consideram que possuem muitos colegas e poucos amigos. Acredita-se que esses dados mantêm estreita relação com a dificuldade que mulheres com TA possuem para estabelecer vínculos concretos, uma vez que apresentam-se muito retraídas e com condutas de evitação (Cassin \& Von Ranson, 2005; Nilsson, Sundboom, \& Häglöff, 2008; Peres \& Santos, 2006). A presença de membros nas redes sociais com quem as participantes mantêm apenas uma relação social (Sluzki, 1997), sem um vínculo de intimidade, pode comprometer o potencial de apoio da rede, pois as participantes não contam com a ajuda desses membros em situações de necessidade física ou emocional.

\subsubsection{Subcategoria B4b - Vida social}

A presente subcategoria diz respeito à realização de atividades de lazer com a companhia de amigos, familiares, namorado e outras pessoas com quem as participantes têm convivência dentro das redes sociais. Tais atividades podem englobar: idas a restaurantes, bares, festas, cinema e eventos sociais em geral, assim como prática de esportes e realização de atividades prazerosas.

A maioria das participantes (Bárbara, Sofia, Maria, Fernanda, Marina, Estrelinha, Ana e Grazieli) realizavam poucas atividades de lazer, sendo estas predominantemente solitárias e desenvolvidas dentro de casa: artesanato (Maria), ler, ouvir música (Fernanda e Sofia) e navegar na internet (Sofia).

Meu lazer é dentro de casa.

Bárbara e Grazieli relataram ir ao shopping center e ao cinema frequentemente, com seus respectivos namorados. No entanto, Bárbara considera muito difícil realizar atividades 
fora de casa, pois sempre há comida envolvida. Dessa forma, a participante relata que o namorado tinha que se esforçar muito para convencê-la a sair.

Apenas três participantes (Amanda, Estrelinha e Juliana) realizavam atividades de lazer com alta frequência. Essas atividades envolviam: festas, bares, reuniões na casa de amigos, entre outros. Em contrapartida, Carolina e Sissi não realizavam atividades de lazer. Antes da instalação do TA, Sissi costumava frequentar a academia de ginástica, fazia aulas de dança do ventre, corria e "saía muito em balada". No entanto, atualmente, sente-se indisposta e prefere ficar em casa sozinha. Carolina, por sua vez, relata que costumava sair com seu primeiro marido para restaurantes e festas, mas "parou de realizar essas atividades há muitos anos".

Para duas participantes (Juliana e Estrelinha), a realização de atividades de lazer parece ser constantemente prejudicada em função de conflitos com os respectivos namorados. Elas relatam que, quando saem com o namorado, acabam brigando por motivos de ciúme, então preferem não sair de casa. Dessa forma, as atividades de lazer acabam sendo realizadas apenas com amigas.

Foi possível notar que as atividades de lazer das participantes do presente estudo são bastante escassas, acarretando em uma vivência social enfraquecida. Acredita-se que esse enfraquecimento da vida social pode resultar em sentimentos de não pertencimento ao meio ambiente em que as participantes vivem, uma vez que as relações com as pessoas desse meio garante o desenvolvimento da identidade do indivíduo e sentimentos de segurança e bem estar (Sluzki, 1997).

\subsubsection{Subcategoria B4c - Família como rede social mais significativa}

A análise das categorias B1, B2 e B3 - que se referiam, respectivamente, à estrutura das redes, aos atributos do vínculo e às funções da rede - demonstraram, de forma geral, que a família configura a rede social mais significativa das participantes. Esse dado foi evidenciado tanto pela análise gráfica dos Mapas de Redes, onde o quadrante da família era o que englobava o maior número de membros, quanto pela análise das funções de apoio, que eram desempenhadas predominantemente por familiares. Neste momento do presente estudo, procurou-se caracterizar de forma mais aprofundada as vivências das participantes dentro da rede social familiar, uma vez que esta se trata da principal fonte de apoio. 
A ambivalência entre conflitos e apoio social ficou bastante clara no discurso de seis participantes (Bárbara, Maria, Fernanda, Sissi, Grazieli e Sofia). Durante as entrevistas, surgiram muitos relatos de brigas e discussões familiares, assim como situações traumáticas que marcaram a vida emocional das participantes, tais como: traição do pai (Sofia e Sissi), cobrança excessiva por parte dos pais (Bárbara, Maria e Grazieli), incompreensão por parte dos irmãos (Grazieli, Fernanda), alcoolismo do pai (Sofia), entre outros.

O meu pai sempre foi um pai muito violento, batia na minha mãe... Eu sempre vi, ele sempre foi adúltero e... Eu sempre cresci muito revoltada, eu e minhas irmãs... Aí, quando eles largaram, ele tentou matar minha mãe... E aí, foi nessa época que eu fiquei... Que aconteceram muitas coisas...

As relações com o pai e com os irmãos foram consideradas vulneráveis, uma vez que houve situações de desentendimentos e eventos traumáticos, nos quais os membros mencionados relatavam não compreender e não aceitar o TA. Wendt e Crepaldi (2008) caracterizam as relações vulneráveis dentro dos Genogramas como "relacionamentos nos quais não há conflito explícito, mas que, entretanto, apresentam risco de haver conflitos em condições adversas ou fases de transição" (p. 305). Ou seja, no caso das participantes do presente estudo, os conflitos com o pai e os irmãos já ocorreram em momentos anteriores, resultando em uma relação que pode facilmente se tornar conflituosa, a partir da ocorrência de adversidades, tais como, por exemplo, uma piora do quadro psicopatológico. Apenas três participantes (Ana, Amanda e Juliana) mencionaram relação de aliança com os irmãos, que foram considerados como fontes significativas de apoio social.

Foram evidenciadas situações de triangulação presentes na dinâmica familiar de sete participantes (Sissi, Grazieli, Maria, Juliana, Estrelinha, Amanda e Ana). Os triângulos eram configurados por relações fundidas e conflituais ou de aliança entre mães e filhas, que atuavam em relação a um terceiro (McGoldrick, Gerson, \& Petry, 2008), o pai. Hipotetiza-se que essas triangulações tenham como função primordial ocultar a relação emocionalmente (ou fisicamente, como no caso dos pais de Amanda) distante do casal parental, por meio da atenção e preocupação excessiva para com a filha acometida pelo TA.

No entanto, apesar dos conflitos descritos nas entrevistas, todas as participantes mencionaram a família como a principal fonte de apoio, especialmente a mãe (Carolina, Sissi, Fernanda e Grazieli), ou ambos os pais (Juliana, Maria, Sofia, Ana e Bárbara). 
Apesar de tudo, assim, são... [os pais] São meus amigos, sabe? São pessoas assim... Que eu digo, que são amigos mesmo, que são pessoas que eu posso contar em qualquer momento, que sempre me escutaram, sabe?

Os discursos das participantes acerca das relações familiares corroboram os pressupostos de Bullock (2004), que sugere que a família configura a rede de apoio mais significativa do indivíduo, ao mesmo tempo em que pode se caracterizar como um espaço onde dinâmicas prejudiciais à saúde do indivíduo podem ocorrer. No contexto do presente estudo, nota-se a existência do que a autora mencionada nomeou de "dinâmicas prejudiciais", que englobam as situações de ameaça, conflitos, cobranças e discussões, além de uma dificuldade, por parte dos pais, em lidar com o TA. Essa dificuldade diz respeito às dúvidas quanto à forma como devem reagir com suas filhas, quanto ao que devem dizer e fazer em relação a elas, ou seja, os pais sentem-se "perdidos" frente ao TA. As dúvidas e incertezas dos pais parecem refletir nas filhas, intensificando os sentimentos de angústia e vazio, fazendo com que as participantes se sintam incompreendidas e sozinhas.

\subsubsection{Subcategoria B4d - Apoio familiar percebido}

Além de mapear as redes sociais das participantes do presente estudo, procurou-se também realizar uma investigação acerca da percepção que elas possuem do apoio social recebido por meio dessas redes. Ao serem questionadas a respeito dessa percepção, as participantes relatavam bastante insatisfação, principalmente com o apoio fornecido pela rede familiar.

Não, eu tenho um apoio, sabe? Mas assim, eu acho que tem horas que é um apoio, assim... Não da forma que... Como eu gostaria, sabe? Porque... Imagina, você viver toda... Assim, sua vida sendo cobrada, ameaçada, sabe assim, então você fica com medo, você vive sempre com medo, assim... Nossa, sempre tendo que atender expectativas.

Satisfeita, satisfeita, não to (...). Eu queria que eles participassem mais do tratamento, principalmente minha irmã mais nova, que é a que convive comigo, então eu queria que ela participasse mais. Porque ela também não entende às vezes, sabe...

Nota-se que a insatisfação com o apoio familiar é decorrente da dificuldade que os pais possuem de lidar com o TA, como já foi mencionado na análise da subcategoria anterior 
(B4c). Algumas participantes relataram que os pais as tratam com ameaças e cobranças, acreditando que dessa forma irão conseguir fazer com que as filhas se alimentem de forma adequada e superem o transtorno. Além disso, a insatisfação com o apoio também parece estar relacionada com o desejo por uma participação mais efetiva dos pais do tratamento. Grazieli relata que sente muita tristeza pelo desinteresse do pai no tratamento, pois este relata que "quem procura chifre na cabeça de boi, encontra", ou seja, o pai não compreende que a filha tem um problema de saúde e que precisa de ajuda.

No que concerne aos outros membros da família, sete participantes (Sofia, Carolina, Amanda, Estrelinha, Sissi, Fernanda e Maria) relataram não ter muito contato com a família extensa. Carolina e Sissi mencionam que não têm relação com tios, primos e avós, e, portanto, esses membros da família não sabem da ocorrência do TA. Maria e Sofia, por sua vez, relatam que todos os seus familiares têm conhecimento do transtorno, mas não falam a respeito. Essas participantes acreditam que os parentes possuem dificuldade para entender o que é um TA, e preferem não se envolver. Nesse sentido, apesar das participantes terem inserido membros da família extensa nos Mapas de Rede - como foi demonstrado pela análise das categorias B1, B2 e B3 -, considera-se que esses membros não podem ser caracterizados como fornecedores de apoio social, uma vez que não mantêm vínculos consistentes com as participantes e, aqueles que mantêm vínculo, preferem manter distância do quadro psicopatológico que elas apresentam.

De uma forma geral, a análise da presente categoria evidenciou uma escassez de atividades de lazer e isolamento social, que impedem a inserção efetiva das participantes nas redes sociais. Notou-se também uma predominância da família nas redes sociais significativas, sendo esta a principal fonte de apoio das participantes. Entretanto, ficou clara a existência de muitos conflitos familiares que comprometem o apoio social fornecido, fazendo com que as participantes tenham uma percepção negativa desse apoio, resultando, assim, em uma grave insatisfação. Acredita-se que essa insatisfação exerça impacto negativo sobre o TA, agravando os sintomas e levando a uma piora do quadro.

A seguir, será realizada uma análise da rede social institucional na qual as participantes do presente estudo estão inseridas, ou seja, o GRATA. 


\subsubsection{Categoria B5 - Rede social institucional: Considerações acerca do tratamento}

Segundo Custódio (2010), a rede social institucional configura a rede de apoio oferecida pelos serviços de saúde disponíveis na instituição hospitalar. Nos casos de TA, essa rede geralmente é constituída por uma equipe multidisciplinar, cujo quadro de profissionais deve englobar: psicólogos, psiquiatras, médicos, enfermeiras, nutricionistas, entre outros. 0 tratamento deve visar à prevenção e a intervenção precoce, além do fornecimento de informações acerca do TA ao público e aos cuidadores dos indivíduos acometidos por esses quadros (McMaster et al., 2004).

Nesse sentido, no contexto do presente estudo, procurou-se analisar a percepção que as participantes apresentavam acerca do apoio fornecido pelos profissionais do serviço de saúde, assim como o impacto que esse apoio exerce sobre o TA e outras considerações relacionadas à inserção no tratamento. Para tanto, a categoria B5 foi dividida em duas subcategorias, a saber: dificuldades no tratamento e GRATA como fonte de apoio social.

\subsubsection{Subcategoria B5a - Dificuldades no tratamento}

Durante a análise das entrevistas, foi possível perceber a existência de algumas dificuldades que as participantes costumam vivenciar no tratamento dentro do serviço de saúde. A participação no grupo de apoio surgiu como principal dificuldade para seis participantes (Fernanda, Carolina, Sofia, Amanda, Marina e Grazieli), que relataram sentir um desconforto ao ver pacientes que fazem seguimento há muitos anos, pois têm medo de vivenciarem a mesma situação. O discurso de Sofia também trouxe algumas impressões acerca do grupo que parecem comprometer sua participação.

Pra mim, como paciente, é um ambiente que eu não me sinto confortável... Ah eu não sei, é difícil explicar. É muito complicado você tá num lugar onde só vão falar do que você precisa fazer, do que você sabe, porque eu acho que todo mundo que tá lá sabe o que tem que fazer, eu acho que todo mundo que ta lá já tem essa consciência. Eu sei o que eu tenho que fazer, mas eu não consigo.

Nota-se, então, que Sofia não considera o grupo como um espaço para trocas mútuas de experiência, conselho e ajuda, mas sim como uma repetição das situações vivenciadas fora do ambiente hospitalar, onde as pessoas costumavam apontar o que a participante deve fazer para melhorar do TA. 
As dificuldades no grupo de apoio também parecem estar relacionadas com a relutância das participantes em falar sobre o TA. Maria, Grazieli e Fernanda relatam que possuem muita dificuldade em se expressar, tanto por não entenderem exatamente do que se trata o transtorno, quanto por remetê-las a questões que as mobilizam intensamente, e das quais elas preferem se distanciar. Fernanda confidencia que costumava mentir nos atendimentos do GRATA, para não precisar falar sobre si.

Agora eu... Eu tô conseguindo falar mais sobre mim... É... Tô conseguindo ser mais verdadeira, sabe? Porque no começo do tratamento é muito difícil, a gente mente muito, eu mesma mentia muito, sabe? E... Pra mim era tudo muito difícil, no começo era tudo muito difícil mesmo, é muito difícil você encarar, você entendeu? Que você tem problema, que você precisa ser tratada.

Aceitar o ganho de peso também surgiu como uma dificuldade para Marina, Fernanda e Maria. Considerando-se que se trata de mulheres com AN, uma das metas do tratamento é a recuperação do peso e a manutenção do mesmo (Associação Americana de Psiquiatria, 2006). Entretanto, o peso constitui uma das questões mais angustiantes para essas pacientes, o que compromete a eficácia do tratamento, uma vez que as participantes apresentam dificuldades para seguir as recomendações nutricionais que implicam no ganho de peso.

Amanda também mencionou a dificuldade da espera pela alta. Ela considera que todas as partes do tratamento são difíceis, incluindo: realizar os atendimentos individuais, participar dos grupos de apoio e seguir as recomendações médicas e nutricionais. No entanto, a cronicidade do quadro psicopatológico, que necessita de um tratamento de longo prazo, parece ter resultado em uma ansiedade pelo momento da alta, que se tornou a dificuldade mais acentuada para Amanda.

\subsubsection{Subcategoria B5b - GRATA como fonte de apoio social}

Ao investigarem-se as percepções que as participantes possuem do apoio fornecido pelos profissionais do serviço de saúde, evidenciou-se que o GRATA configurava uma significativa fonte de apoio social. Quando questionadas a respeito das principais fontes de apoio em suas redes sociais, seis participantes (Grazieli,Estrelinha, Juliana, Sofia, Bárbara e Maria) mencionaram o GRATA, juntamente com alguns outros membros das redes. 
Todas as participantes relataram sentir-se acolhidas pelos profissionais, o que possibilitava o desenvolvimento de um vínculo importante entre paciente e profissional que, por sua vez, facilitava a assiduidade no tratamento, o seguimento das recomendações clínicas e o uso correto dos medicamentos, proporcionando melhoras progressivas do quadro.

Me sinto muito acolhida, às vezes eu tô numa semana que eu não to muito bem, e aí vem mil pensamentos, assim, e eu fico focada, assim: "Não, ta chegando sexta-feira, na sexta-feira eu sei que eu posso contar pra alguém que vai me ajudar" e tal... Eu sempre me sinto muito acolhida aqui.

Algumas participantes mencionam a relação com profissionais específicos do serviço de saúde, com quem puderam construir um vínculo mais significativo. Segundo os discursos das participantes, esses profissionais constituíram uma fonte de apoio importante em momentos de crise - principalmente nos momentos de ideação suicida - e forneceram subsídios para que as participantes pudessem enxergar formas mais funcionais de lidar com suas dificuldades.

Não queria viver mais, sabe? Não tinha esperanças, assim... Não sei... Minha autoestima tava muito baixa, e eu não tinha vontade de viver... Aí, eu peguei os medicamentos que eu tomava... Uns dos medicamentos que eu tomava, misturei tudo, tomei [...]. Uma outra coisa também que marcou bastante durante o tratamento foi, é... O tempo em que eu tratei com a $R$. [nutricionista] aqui, sabe? Eu tive muito apoio, não que eu não tenha agora, eu tenho apoio de todos os profissionais, mas a R., assim, foi um... Uma... A médica assim que marcou pra mim, sabe? Porque ela me ajudou muito no começo... Tive muito apoio dela mesmo, assim, por ser começo, sabe? De ver a paciência que ela tinha comigo... Você entendeu?

Fernanda e Grazieli também relatam a percepção de melhoras do quadro, e atribuem essas melhoras ao tratamento. Ambas as participantes mencionam que "estão tendo um acompanhamento muito bom". Bárbara e Sofia, que estão no início do tratamento - há um mês e seis meses, respectivamente -, relatam que já se sentem acolhidas pelos profissionais e acreditam que o tratamento no GRATA possibilitará uma melhora significativa do quadro.

Retomando as análises dos Mapas de Redes, foi possível notar que os profissionais do serviço de saúde constituíam uma parte importante dos Mapas, desempenhando predominantemente a função de guia cognitivo e conselhos, conforme descrito nas 
categorias B2 e B3 - respectivamente, Atributos do Vínculo e Funções da Rede. Esses dados estão de acordo com os relatos das participantes nas entrevistas, nos quais se evidenciou uma importância significativa atribuída ao acolhimento e ao apoio fornecidos pelos profissionais do GRATA, que encontram-se estreitamente relacionados com a efetividade do tratamento e a percepção de melhora do quadro, ou com a crença em melhoras futuras. 


\section{CONSIDERAÇÕES FINAIS}

O presente estudo teve como objetivo geral investigar o modo como se configuram as redes sociais de mulheres com diagnóstico de TA, assim como o apoio social percebido por elas e suas possíveis implicações para a evolução do quadro psicopatológico. Nesse sentido, observou-se que as redes sociais significativas eram amplas ou, em um número menor de casos, de tamanho médio, com membros mal distribuídos entre os quadrantes dos Mapas de Redes. Houve predomínio da família, cujos membros constituíram a maior parte das redes sociais representadas neste estudo, englobando 86 indivíduos, do total de 177 membros de todas as redes. Dessa forma, a rede familiar foi caracterizada como a principal fonte de apoio das participantes.

As redes de amigos, colegas de trabalho/faculdade e da comunidade incluíram um total de membros significativamente menor do que a rede familiar, sendo respectivamente: 31, 28 e 10 membros. Antes da ocorrência do TA, algumas participantes tinham poucos amigos e realizavam poucas ou nenhuma atividade de lazer. Em contrapartida, outras possuíam redes sociais mais amplas, que incluíam amigos e colegas de trabalho com quem realizavam atividades de lazer, tais como frequentar bares e festas. A partir de um rebaixamento na autoestima e da ocorrência de uma série de eventos estressores - que englobavam separações conjugais, relacionamentos familiares disfuncionais, cobranças por parte de membros da família, perdas de pessoas queridas, exposição a apelidos depreciativos, entre outros - que as participantes consideravam como precipitantes do TA, o isolamento social parece ter se instaurado na vida dessas mulheres, de modo que as redes de amizade foram se tornando cada vez mais escassas, favorecendo a predominância da rede familiar.

Nesse sentido, evidenciou-se que o apoio social principal era proveniente das relações familiares, ainda que estas fossem marcadas por conflitos, discussões e triangulações, que permeavam as relações antes mesmo da instalação do TA. Considerandose a estreita relação existente entre a dinâmica familiar e a manutenção do quadro psicopatológico em questão, as participantes apresentaram anseios por mudanças nas relações familiares, acreditando que essas alterações poderiam contribuir para uma melhora do quadro. Tais mudanças incluíam: mais diálogo, proximidade e carinho nas relações, 
menos conflitos fraternos, maior participação da família no tratamento e maior união familiar.

A predominância da rede familiar, com quem as participantes mantinham vínculos naturalizados por laços de sangue antes mesmo da instalação do TA, juntamente com a escassez de amigos, colegas de trabalho e indivíduos de outras redes sociais, indicam a existência de dificuldades no estabelecimento de vínculos concretos e na manutenção de relacionamentos afetivos e conjugais duradouros, o que parece comprometer a qualidade dessas relações e desencorajar a aproximação a pessoas do meio. Nesse sentido, considerase necessária a problematização da qualidade dos vínculos significativos que as mulheres com esses quadros estabelecem com os membros de suas redes sociais. Vale ressaltar a importância dos profissionais da área de incluírem os membros dessas redes na assistência, buscando melhorar as relações e explorar o potencial de apoio das redes sociais. Tal aprimoramento na assistência resultaria em melhor qualidade de vida das pacientes, uma vez que a qualidade de vida está intimamente relacionada com a qualidade das relações sociais do indivíduo.

A relação das participantes com a mãe emergiu como um dado significativo neste estudo. Trata-se de uma relação ambivalente, que envolve sentimentos de amor e carinho e, em contrapartida, implica em indiferenciação, dependência mútua e conflitos não solucionados, resultando em tensão permanente. No entanto, apesar das freqüentes situações de conflito presentes na relação mãe e filha, a figura materna foi caracterizada como a principal fonte de apoio das participantes, o que sugere uma centralização do apoio fornecido. Levando-se em conta que a concentração do cuidado em apenas um ou poucos membros da rede social pode sobrecarregá-los, considera-se que a distribuição do cuidar seja mais saudável e proporcione efetividade à ajuda prestada.

O baixo grau de acesso a novos contatos, assim como a onipresença da figura da mãe como responsável pelo exercício de diversas funções familiares, permite pensar na importância do acolhimento dos cuidadores familiares. Os profissionais de saúde que atuam na área dos TA devem realizem esforços para promoção de uma assistência integral e sistêmica, na qual o cuidado possa ser distribuído entre os vários membros constituintes das redes sociais significativas do paciente. Ao considerar as reais possibilidades de cada um, o profissional pode valorizar as relações que propiciam melhoria na qualidade de vida do indivíduo e, assim, conseguir angariar aliados na família do paciente, ou na própria 
comunidade, que devem ser valorizados e incluídos no tratamento. Nesse sentido, o presente estudo leva em consideração o pressuposto de que a dimensão relacional é central no adoecimento, sendo, portanto, fundamental na proposta de recuperação e reabilitação da pessoa acometida.

Em suma, ao levar em consideração os fundamentos teóricos que sustentam o presente estudo, é possível pensar que as relações interpessoais de baixa qualidade e a dificuldade de manter vínculos diminuem o potencial de apoio recebido pelas participantes por meio de suas redes pessoais, o que pode levar ao não cumprimento do plano terapêutico e, consequentemente, ao agravamento dos sintomas de TA, já que as redes e o apoio social mantêm estreita relação com o bem-estar físico e mental dos indivíduos.

Uma vez que o cuidado integral das pacientes com TA não se restringe apenas ao acompanhamento nutricional, psiquiátrico e psicológico de forma isolada, acredita-se que os elementos resultantes do presente estudo apontam para a necessidade de que a equipe multidisciplinar dimensione os impactos que as redes sociais acarretam na saúde dos indivíduos. Esse conhecimento pode oferecer subsídios valiosos para aprimorar os recursos de tratamento dos TA, orientando, especialmente, os modos de incluir as redes de apoio na assistência, de modo a prevenir os agravos à saúde e promover o bem-estar.

Cabe salientar também o uso do Mapa de Redes e do Genograma como instrumentos relevantes de pesquisa e intervenção na área da saúde, na medida em que possibilitam a verificação do tamanho e da qualidade das redes de apoio social, assim como os tipos de relacionamento e de vínculo existentes entre os membros da família. O processo de construção desses instrumentos permite que o indivíduo visualize o tipo de relações que ele vem estabelecendo ao longo de sua vida, o que estimula a reflexão e a auto-observação. Levando-se em conta os resultados obtidos com a utilização do Mapa de Redes e do Genograma no presente estudo, conjugados com a entrevista semi-estruturada, é possível considerá-los como instrumentos que se mostraram úteis na identificação da necessidade de apoio e na visualização dos recursos disponíveis nas redes de indivíduos que se encontram em situação de doença crônica, o que possibilita o planejamento de intervenções que incluam a família e outras pessoas que constituem a rede significativa da pessoa acometida.

No entanto, vale ressaltar que as relações humanas, assim como a estrutura das redes sociais significativas e a percepção o apoio social recebido, possuem uma dinamicidade, ou seja, encontram-se em constante movimento e modificação. Pessoas são 
incluídas nas redes sociais como fontes importantes de apoio e, algum tempo depois, devido a rompimentos nas relações ou às inúmeras possíveis adversidades da vida, acabam sendo afastadas daquela rede, modificando sua estrutura e abrindo espaço para que outras pessoas possam fazer parte dela. Nesse sentido, é válido ressaltar que, apesar do presente estudo apresentar dados expressivos acerca das redes sociais, dos vínculos estabelecidos com pessoas significativas e da dinâmica das relações familiares de mulheres com TA, os resultados encontrados não podem ser considerados estáticos, e sim como concernentes a um momento específico da trajetória de vida das participantes. Além disso, a dificuldade de quantificação dos membros das redes também se apresentou como uma limitação ao presente estudo, uma vez que implicou no trabalho com números aproximados, e não exatos, das pessoas que constituíam essas redes. 


\section{REFERÊNCIAS}

Abreu, N., \& Filho, R. C. (2004). Anorexia nervosa e bulimia nervosa: Abordagem cognitivoconstrutivista de psicoterapia. Revista de Psiquiatria Clínica, 31(4), 177-183.

Adami-Lauand, C. B. (2010). As experiências alimentares de mães com filhas portadoras de transtornos alimentares: Investigando a transgeracionalidade. Dissertação de mestrado não publicada, Universidade de São Paulo, Ribeirão Preto, SP.

Ambrósio, D. C. M. (2010). Mulheres com câncer de mama: A vivência do apoio social e familiar durante o tratamento. Dissertação de mestrado não publicada, Universidade de São Paulo, Ribeirão Preto, SP.

Andreani, G., Crepaldi, M. A., \& Custódio, Z. A. O. (2006). Tecendo as redes de apoio na prematuridade. Aletheia, 24, 115-126.

Areemit, R. S., Katzman, D. K., Pinhas, L., \& Kaufman, M. E. (2010). The experience of siblings of adolescents with eating disorders. Journal of Adolescent Health, 46(6), 569-576.

Associação Americana de Psiquiatria. (2002). DSM-IV-TR $R^{T M}$ - Manual diagnóstico e estatístico de transtornos mentais: Texto revisado (C. O. Dornelles, Trad., 4a ed. revisada). Porto Alegre: Artmed.

Associação Americana de Psiquiatria. (2006). Manual de tratamento de pacientes com transtornos alimentares. Arlington, EUA. Recuperado em 17 de novembro, 2009, de http://www.psych.org.

Associação Brasileira de Empresas de Pesquisas. (2010). Critério Brasil 2010: Base LSE 2008. Recuperado em 20 de dezembro, 2011. Disponível em: http://www.abep.org/novo/ Content.aspx?ContentID=302.

Berge, J. M., Loth, K., Hanson, C., Croll-Lampert, J., \& Neumark-Sztainer, D. (2011). Family life cycle transitions and the onset of eating disorders: A retrospective grounded theory approach [Versão eletrônica]. Journal of Clinical Nursing. Disponível em: http://dx.doi.org/10.1111/j.1365-2702.2011.03762.x.

Björk, B., \& Ahlström, G. (2008). The patient's perception of having recovered from an eating disorder. Health Care for Women International, 29(8-9), 926-944. 
Bogdan, R.C., \& Biklen, S.K. (1994). Investigação qualitativa em educação: uma introdução à teoria e aos métodos (M. J. Alvarez, S. B. Santos, \& T. M. Batista. Trad). Porto, Portugal: Ciência da Educação.

Borges, N. J. B. G., Sicchieri, J. M. F., Ribeiro, R. P. P., Marchini, J. S., \& Santos, J. E. (2006). Transtornos alimentares: Quadro clínico. Medicina (Ribeirão Preto), 39(3), 340-348.

Borzekowski, D. L. G., Schenk, S., Wilson, J. L., \& Peebles, R. (2010). E-Ana and e-Mia: A content analysis of pro-eating disorder websites. American Journal of Public Health, 100(8), 1526-1534.

Brito, R. C., \& Koller, S. H. (1999).Desenvolvimento humano e redes de apoio social e afetivo (p.115-129). In A. M. Carvalho (Org.) O mundo social da criança: Natureza e cultura em ação. São Paulo: Casa do Psicólogo.

Brotsky, S. R. \& Giles, D. (2007). Inside the "pro-ana" community: A covert online participant observation. Eating Disorders, 15(2), 93-109.

Brusset, B. (2003). Introdução Geral. In B. Brusset, C. Couvreur, \& A. Fine (Orgs.), A bulimia (p. 7-13). São Paulo: Escuta.

Bryant-Waugh, R., \& Lask, B. (1995). Eating disorders: An overview. Journal of Family Therapy, 17(1), 13-30.

Bullock, K. (2004). Family social support. In P. J. Bomar (Ed.), Promoting health in families: Applying research and theory to nursing practice (pp. 141-161). Philadelphia, PA: Saunders.

Cabrera, C.C. (2006). Estratégias de intervenção interdisciplinar no cuidado com o paciente com transtorno alimentar: O tratamento farmacológico. Medicina (Ribeirão Preto), 39(3), 375-380.

Carter, B., \& McGoldrick, M. (2001). As mudanças no ciclo de vida familiar: Uma estrutura para a terapia familiar (2 $\mathrm{a}$ Ed.). Porto Alegre, RS: Artmed.

Cassin, S. E., \& Von Ranson, K. M. (2005).Personality and eating disorders: A decade in review. Clinical Psychology Review, 25(7), 895-916.

Claudino, A. M., \& Borges, M. B. F. (2002). Critérios diagnósticos para os transtornos alimentares: Conceitos em evolução. Revista Brasileira de Psiquiatria, 24(3), 7-12. 
Claudino, A. M., \& Zanela, M. T. (2002). Transtornos alimentares e obesidade. São Paulo: Manole.

Cooley, E., Toray, T., Wang, M. C., \& Valdez, N. N. (2008). Maternal effects on daughters' eating pathology and body image. Eating Behaviors, 9(1), 52-61.

Cooper, M. J., Deepak, K., Grocutt, E., \& Bailey, E. (2007). The experience of 'feeling fat' in women with anorexia nervosa, dieting and non-dieting women: An exploratory study. European Eating Disorders Review, 15(5), 366-372.

Csipske, E. \& Horne, O. (2007). Pro-eating disorder websites: User's opinions. European Eating Disorders Review, 15(3), 196-206.

Cunha, A. I., Relvas, A. P., \& Soares, I. (2009). Anorexia nervosa and family relationships: Perceived family functioning, coping strategies, beliefs, and attachment to parents and peers. International Journal of Clinical and Health Psychology, 9(2), 229-240.

Custódio, Z. A. O. (2010). Redes sociais no contexto da prematuridade: Fatores de risco e de proteção para o desenvolvimento da criança ao longo dos seus dois primeiros anos de vida. Tese de doutorado. Programa de Pós-graduação em Psicologia da Universidade Federal de Santa Catarina, Florianópolis, SC.

Dallos, R., \& Denford, S. (2008). A qualitative exploration of relationship and attachment themes in families with an eating disorder. Clinical Child Psychology and Psychiatry, 13(2), 305-322.

Dimitropoulos, G., Carter, J., Schachter, R., \& Woodside, D. B. (2008).Predictors of family functioning in carers of individuals with anorexia nervosa. International Journal of Eating Disorders, 41(8), 739-747.

Dunker, K. L., \& Phillipi, S. T. (2003).Hábitos e comportamentos alimentares de adolescentes com sintomas de anorexia nervosa. Revista de Nutrição,16(1), 51-60.

Filho, N. G. V., \& Nóbrega, S.M. (2004). A atenção psicossocial em saúde mental: contribuição teórica para o trabalho terapêutico em rede social. Estudos de Psicologia, 9(2), 373-379.

Gil, A. C. (1991) Como elaborar projetos de pesquisa. São Paulo: Atlas. 
Gillet, K. S., Harper, J. M., Larson, J. H., Berrett, M. E., \& Hardman, R. K. (2009). Implicit family rules in eating-disordered and non-eating-disordered families. Journal of Marital and Family Therapy, 35(2), 159-174.

Giordani, R. C. F. (2006). A auto-imagem corporal na anorexia nervosa: Uma abordagem sociológica. Psicologia e Sociedade, 18(2), 81-88.

Gutierrez, D. M. D., \& Minayo, M. C. S. (2008). Família, redes sociais e saúde: O imbricamento necessário. Anais do VIII Fazendo Gênero: Corpo, violência e poder. Universidade de Santa Catarina, Florianópolis, SC. Recuperado em 19 de janeiro, 2011, de http://www.fazendogenero.ufsc.br/8/sts/ST34/Gutierrez-Minayo_34.pdf.

Hillege, S., Beale, B., \& McMaster, R. (2006). Impact of eating disorders on family life: individual parent's stories. Journal of Clinical Nursing, 15(8), 1016-1022.

Hoek, H. W., \& Hoeken, D. (2003). Review of the prevalence and incidence of eating disorders. International Journal of Eating Disorders, 34(4), 383-396.

Honey, A., Clarke, S., Halse, C., Kohn, M., \& Madden, S. (2006). The influence of siblings on the experience of anorexia nervosa for adolescent girls. European Eating Disorders Review, 14(5), 315-322.

Hutchinson, D. M., \& Rapee, R. M. (2007). Do friends share similar body image and eating problems? The role of social networks and peer influences in early adolescence. Behavior Research and Therapy, 45(7), 1557-1577.

Jones, C. J., Leung, N., \& Harris, G. (2006).Father-daughter relationship and eating psychopathology: The mediating role of core beliefs. British Journal of Clinical Psychology, 45(3), 319-330.

Karpowicz, E., Skärsäter, I., \& Nevonen, L. (2009).Self-esteem in patients treated for anorexia nervosa. International Journal of Mental Health Nursing, 18(5), 318-325.

Kaye, W. (2008). Neurobiology of anorexia and bulimia nervosa. Physiology \& Behavior, 94(1), 121-135.

Kluck, A. S. (2008). Family factors in the development of disordered eating: Integrating dynamic and behavioral explanations. Eating Behaviors, 9(4), 471-483.

Krom, M. (2000). Família e mitos - prevenção e terapia: resgatando histórias. São Paulo: Summus. 
Krüger, L. L., \& Werlang, B. S. G. (2008). O genograma como recurso no espaço conversacional terapêutico. Revista Avaliação Psicológica, 7(3), 414-426.

Lane, R. C. (2002). Anorexia, masochism, self-mutilation, and autoerotism: The spider mother. Psychoanalitic Review, 89(1), 101-123.

Leonidas, C., \& Santos, M. A. (2011). O papel das redes sociais e do apoio social no tratamento dos transtornos alimentares. Submetido para publicação na Revista LatinoAmericana de Enfermagem.

Limbert, C. (2010). Perceptions of social support and eating disorder characteristics. Health Care for Women International, 31(2), 170-187.

Marcos, Y. Q., \& Cantero, M. C. T. (2009). Assessment of social support dimensions in patients with eating disorders. The Spanish Journal of Psychology, 12(1), 226-235.

Maykut, P., \& Morehouse, R. (1994). Beggining qualitative research: A philosophic and practical guide. Londres: Farmer Press Teacher's Library.

McGoldrick, M., \& Gerson, R. (1995). Genetogramas e o ciclo de vida familiar (M. A. V. Veronese Trad.). In B. Carter \& M. McGoldrick, M. (Eds.), As mudanças no ciclo de vida familiar - Uma estrutura para a terapia familiar (2ª ed.). Porto Alegre: Artes Médicas.

McGoldrick, M., Gerson, R. \& Petry, S. (2008). Genograms: assessment and intervention. 3a ed. Nova York: W. W. Norton Co Inc.

McMaster, R., Beale, B., Hillege, S., \& Nagy, S. (2008). The parent experience of eating disorders: Interactions with health professionals. International Journal of Mental Health Nursing, 13(1), 67-73.

McNamara, K., \& Loveman, C. (1990). Differences in family functioning among bulimics, repest dieters, and nondieters .Journal of Clinical Psychology, 46(3), 518-523.

Minayo, M. C. S. (1994). O desafio do conhecimento: pesquisa qualitativa em saúde. São Paulo-Rio de Janeiro: Hucitec-Abrasco.

Minuchin, S., Baker, L., Rosman, B.L., Liebman, R., Milman, L., \& Todd, T.C. (1975).A conceptual model of psychosomatic illness in childhood: Family organization and family therapy. Archives of General Psychiatry, 32, 1031-1038. 
Moré, C. L. O. O. (2005). As redes pessoais significativas como instrumento de intervenção psicológica no contexto comunitário. Paidéia (Ribeirão Preto), 15(31), 287-297.

Morgan, C. M., Vecchiatti, I. R., \& Negrão, A. B. (2002). Etiologia dos transtornos alimentares: aspectos biológicos, psicológicos e socioculturais. Revista Brasileira de Psiquiatria, 24(3), 18-23.

Mulveen, R. \& Hepworth, J. (2006). An interpretative phenomenological analysis of participation in a pro-anorexia internet site and its relationship with disordered eating. Journal of Health Psychology, 11(2), 283-296.

Nilsson, K., Sundbom, E., \& Häglöf, B. (2008). A longitudinal study of perfectionism in adolescent onset anorexia nervosa, restricting type. European Eating Disorders Review, 16(5), 386-394.

Oliveira, E. A., \& Santos, M. A. (2006). Perfil psicológico de pacientes com anorexia e bulimia nervosas: A ótica do psicodiagnóstico. Medicina (Ribeirão Preto), 39(3), 353-360.

Orlandi, R. (2011). Participação da rede social significativa de mulheres que vivem e convivem com o HIV no enfrentamento da soropositividade. Tese de doutorado. Programa de Pós-graduação em Psicologia da Universidade Federal de Santa Catarina, Florianópolis, SC.

Paccola, A. T. F. (2006). Escuta do psiquiatra: Sinais e sintomas de anorexia nervosa e bulimia nervosa. Medicina (Ribeirão Preto), 39(3), 349-352.

Peres, R. S., \& Santos, M. A. (2006). Contribuições do Desenho da Figura Humana para a avaliação da imagem corporal na anorexia nervosa. Medicina (Ribeirão Preto), 39(3), 361-370.

Polit, D. F., Beck, C. T., \& Hungler, B. P. (2004). Fundamentos de pesquisa em enfermagem: Métodos, avaliação e utilização (A. Thorell, Trad.). 5a ed. Porto Alegre: Artmed.

Ransom, D. C., La Guardiã, J. G., Woody, E. Z., \& Boyd, J. L. (2010). Interpersonal interactions on on-line forums addressing eating concerns. International Journal of Eating Disorders, 43(2), 161-170.

Resende, M. C., Bones, V. M, Souza, I. S., \& Guimarães, N. K. (2006). Rede de relações sociais e satisfação com a vida de adultos e idosos. Psicologia para a América Latina, 5.Recuperado em 23 de novembro, 2010, de http://pepsic.homolog.bvsalud. org/scielo.php?script=sci_arttext\&pid=S187050X2006000100015\&Ing=pt\&nrm=iso. 
Rodríguez, M. B., Hernández, A. P., \& Bouly, R. P. (2007). Anorexia nerviosa: Características y síntomas. Revista Cubana de Pediatria, 72(4), 300-305.

Rosa, B. P., \& Santos, M. A. (2011). Comorbidade entre bulimia e transtorno de personalidade borderline: Implicações para o tratamento. Revista Latinoamericana de Psicopatologia Fundamental, 14(2), 268-282.

Santos, A. C. W. (2009). Mulheres, violência, rede de serviços de referência e suporte psicosocial. Dissertação de mestrado. Programa de Pós-graduação em Psicologia da Universidade Federal de Santa Catarina, Florianópolis, SC.

Santos, M. A. (2010). Escuta psicanalítica no contexto hospitalar: O grupo como agenciador de recursos que potencializam mudanças. In Anais do XII Simpósio CEFAS e I Simpósio Associação Criança - Saúde mental e práticas institucionais: Casal, familia, grupo, criança e adolescente [CD-ROM]. Sorocaba: Centro de Formação e Asisstência à Saúde (CEFAS).

Schmidt, E., \& Mata, G. F. (2008). Anorexia Nervosa: Uma revisão. Fractal, 20(2), 387-400.

Shomaker, L. B., \& Furman, W. (2009). Interpersonal influences on late adolescent girls' and boys' disordered eating. Eating Behaviors, 10(2), 97-106.

Sicchieri, J. M. F., Santos, M. A., Santos, J. E., \& Ribeiro, R. P. P. (2007). Avaliação nutricional de portadores de transtorno alimentar: Resultados após a alta hospitalar. Ciência, Cuidado e Saúde, 6(1), 68-75.

Silva, I., Pais-Ribeiro, J., Cardoso, H., Ramos, H., Carvalhosa, S. F., Dias, S., \& Gonçalvez, A. (2003). Efeitos do apoio social na qualidade de vida, controle metabólico e desenvolvimento de complicações crônicas em indivíduos com diabetes. Psicologia, Saúde e Doenças, 4(1), 21-32.

Sluzki, C. E. (1997). A rede social na prática sistêmica: Alternativas terapêuticas (C. Berliner, Trad.). São Paulo: Casa do Psicólogo.

Soenens, B., Vamsteenkiste, M., Vandereycken, W., Luyten, P., Sierens, E., \& Goossens, L. (2008). Perceived parental psychological control and eating-disordered symptoms: Maladaptative perfectionism as a possible intervening variable. The Journal of Nervous and Mental Disease, 196(2), 144-152.

Sopezcki, D. \& Vaz, C. E. (2008). O impacto da relação mãe-filha no desenvolvimento da autoestima e nos transtornos alimentares. Interação em Psicologia, 12(2), 267-275. 
Souza, L. V., \& Santos, M. A. (2006). A família e os transtornos alimentares. Medicina (Ribeirão Preto), 39(3), 403-409.

Souza, L. V., Santos, M. A., \& Scorsolini-Comin, F. (2009). Percepções da família sobre a anorexia e bulimia nervosa. Vínculo: Revista do NESME, 1(6), 26-38.

Sweetingham, R., \& Waller, G. (2008). Childhood experiences of being bullied and teased in the eating disorders. European Eating Disorders Review, 16(5), 401-407.

Symansky, H. (2004) A pesquisa intervenção participante com famílias de baixa renda: um projeto participativo de atenção psicossocial. In C. R. Althoff, I. Elsen \& R. G. Nitschke (Ed.), Pesquisando a família: olhares contemporâneos (p. 115-125). Florianópolis: Papa Livro.

Triviños, A. N. S. (1987) Introdução à pesquisa em ciências sociais: a pesquisa qualitativa em educação. São Paulo: Atlas.

Vaux, A. (1988). Social support: Theory, research and intervention. New York: Praeger.

Vindreau, C. (2003). A bulimia na clínica psiquiátrica. In B. Brusset, C. Couvreur, \& A. Fine (Orgs.), A bulimia (p. 81-102). São Paulo: Escuta.

Wendt, N.C., \& Crepaldi, M.A. (2008). A utilização do genograma como instrumento de coleta de dados na pesquisa qualitativa. Psicologia: Reflexão e Crítica, 21(2), 302-310.

Wertheim, E.H., Martin, G., Prior, M., Sanson, A. \& Smart, D. (2002). Parent influences in the transmission of eating and weight related values and behaviors. Eating Disorders, 10(4), 321-334.

Winn, S., Perkins, S., Walwyn, R. Schmidt, U., Eisler, I., Treasure, J., Berelowitz, M., Dodge, L., Frost, S., Jenkins, M., Johnson-Sabine, E., Keville, S., Murphy, R., Robinson, P., \& Yi, I. (2007). Predictors of mental health problems and negative caregiving experiences in carers of adolescents with bulimia nervosa. International Journal of Eating Disoders, 40(2), 171-178.

Wright, L., \& Leahy, M. (2002). Enfermeiras e família: um guia para avaliação e intervenção na família. 3a ed. São Paulo: Roca. 


\section{ANEXOS}

\section{Anexo 1. Legendas dos Genogramas, segundo Wendt e Crepaldi (2008), baseado em McGoldrick e Gerson (1995)}

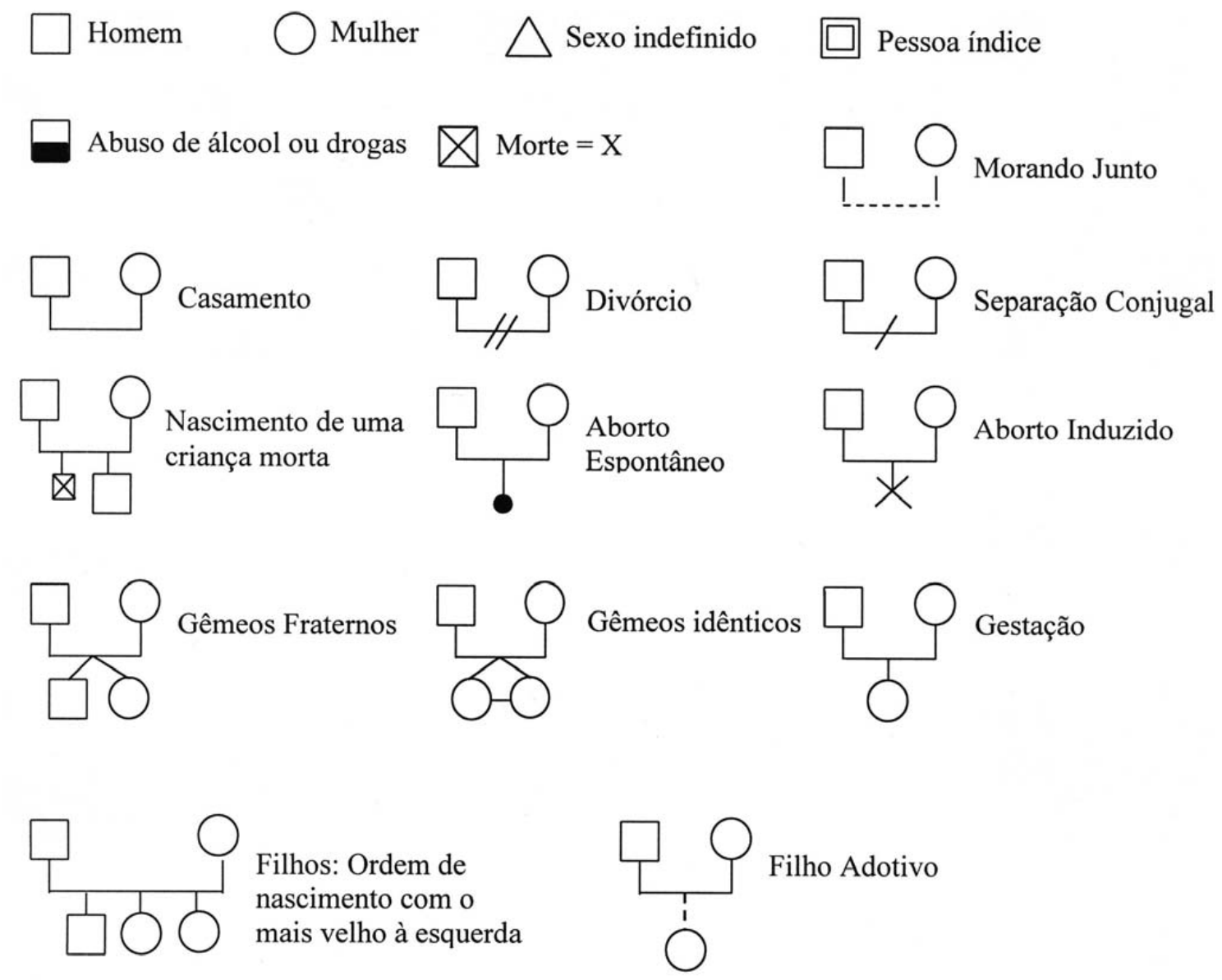

Relacionamentos:

$\square---\bigcirc$ Distante

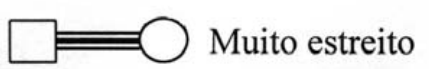<smiles>CCC(C)(CO)CO</smiles>

Coalizão $\square$ Conflituoso

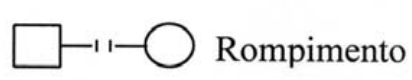

$\square+$ Fundido e Conflitual
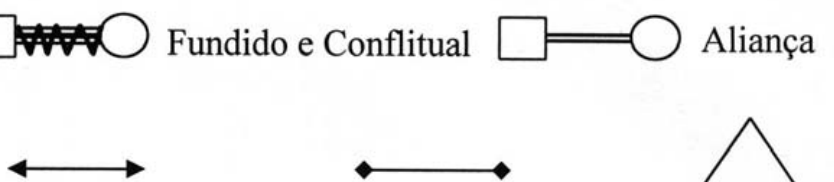

Harmônico

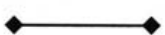

Vulnerável

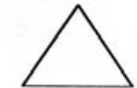

Triangulação 


\section{Anexo 2. Critério de Classificação Econômica Brasil 2010}

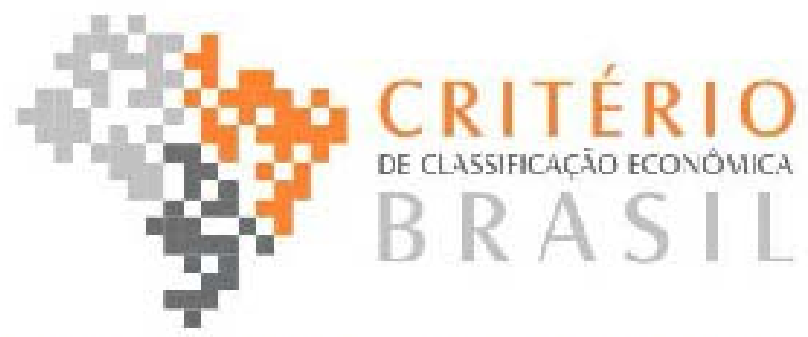

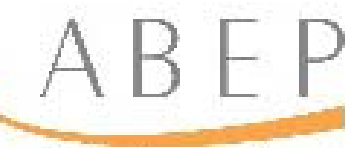

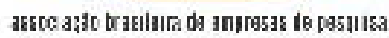

O Critério de Classificação Econômica Brasil, enfatiza sua funçäo de estimar o poder de compra das pessoas e familias urbanas, abandonando a pretensấo de classificar a população em termos de "classes sociais". A divisäo de mercado definida abaixo é de classes econômicas.

\section{SISTEMA DE PONTOS}

Posse de itens

\begin{tabular}{|c|c|c|c|c|c|}
\hline & \multicolumn{5}{|c|}{ Quantidade de itens } \\
\hline & 0 & 1 & 2 & 3 & 4 out $t$ \\
\hline Televisāo em cores & 0 & 1 & 2 & 3 & 4 \\
\hline Rádio & 0 & 1 & 2 & 3 & 4 \\
\hline Banheiro & 0 & 4 & 5 & 6 & 7 \\
\hline Automóvel & 0 & 4 & 7 & 9 & 9 \\
\hline Empregada mensalista & 0 & 3 & 4 & 4 & 4 \\
\hline Máquina de lavar & 0 & 2 & 2 & 2 & 2 \\
\hline Videocassete e/ou DVD & 0 & 2 & 2 & 2 & 2 \\
\hline Geladeira & 0 & 4 & 4 & 4 & 4 \\
\hline Freezer (aparelho independente ou parte da geladeira duplex) & 0 & 2 & 2 & 2 & 2 \\
\hline
\end{tabular}

Grau de Instrução do chefe de família

Analfabeto / Primário incompleto

Primário completo / Ginasial incompleto

Ginasial completo / Colegial incompleto

colegial completo / Superior incompleto

Superior completo
Analfabeto / Até $3^{*}$. Série Fundamental Até $4^{*}$. Série Fundamental Fundamental completo

Médio completo

Superior completo

\section{CORTES DO CRITÉRIO BRASIL}

\begin{tabular}{|c|c|}
\hline Classe & Pontos \\
\hline A1 & $42-46$ \\
\hline A2 & $35-41$ \\
\hline B1 & $29-34$ \\
\hline B2 & $23-28$ \\
\hline C1 & $18-22$ \\
\hline C2 & $14-17$ \\
\hline D & $8-13$ \\
\hline E & $0-7$ \\
\hline
\end{tabular}




\section{Anexo 3. Aprovação do Comitê de Ética em Pesquisa do Hospital das Clínicas da Faculdade de Medicina de Ribeirão Preto da Universidade de São Paulo (HC-FMRP-USP)}

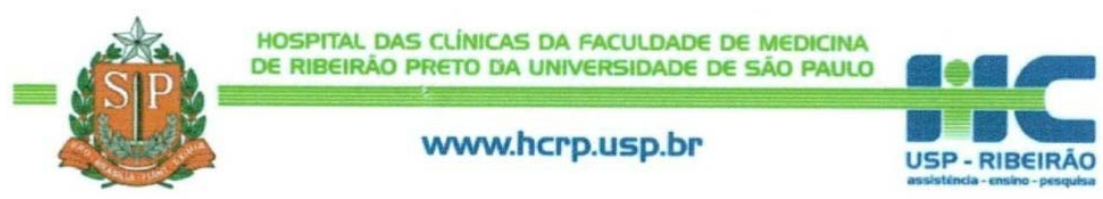

Ribeirão Preto, 13 de abril de 2010

Oficio $\mathrm{n}^{\circ} 1111 / 2010$

CEP/MGV

Prezados Senhores,

O trabalho intitulado "REDE FAMILIAR, SOCIAL E PESSOAL DE PACIENTES COM BULIMIA NERVOSA" foi analisado pelo Comitê de Ética em Pesquisa, em sua $305^{\mathrm{a}}$ Reunião Ordinária realizada em 12/04/2010 e enquadrado na categoria: APROVADO, bem como o Termo de Consentimento Livre e Esclarecido, de acordo com o Processo HCRP $\mathrm{n}^{\circ} 2155 / 2010$.

Este Comitê segue integralmente a Conferência Internacional de Harmonização de Boas Práticas Clínicas (IGH-GCP), bem como a Resolução no 196/96 CNS/MS.

Relatório Parcial e o Relatório Final da pesquisa.

Lembramos que devem ser apresentados a este CEP, 0 Atenciosamente.

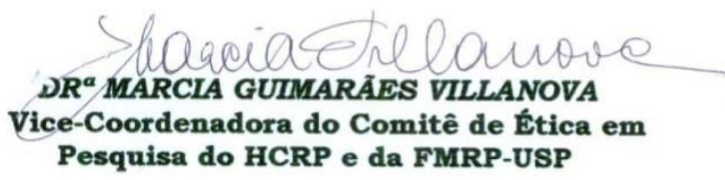

Ilustríssimos Senhores

CAROLINA LEONIDAS

PROF. DR. MANOEL ANTÔNIO DOS SANTOS (Orientador)

Faculdade de Filosofia, Ciências e Letras de Ribeirão Preto-USP - Depto. de Psicologia e Educação - NEPPS

\footnotetext{
Comitê de Ética em Pesquisa HCRP e FMRP-USP - Campus Universitário

FWA - 0000 2733; IRB - 00002186 e Registro SISNEP/CONEP n ${ }^{\circ} 4$

Fone (16) 3602-2228 - E-mail : cep@hcrp.usp.br
} 


\section{APÊNDICES}

\section{Apêndice 1. Roteiro de entrevista semi-estruturada}

\section{Dados sociodemográficos:}

Nome:

Naturalidade: Procedência:

Idade: Nível de escolaridade:

Ocupação:

Situação conjugal: Filhos: ( ) sim

( ) não Quantos:

Renda familiar:

№ de pessoas que moram na residência:

Tipo de moradia (própria, alugada, emprestada):

Religião: Praticante: ( ) sim ( ) não Frequência semanal:

Faz parte de algum grupo? De que tipo? Com que frequência?

\section{Informações acerca do transtorno alimentar}

- Atualmente, quais são suas dificuldades com a alimentação?

- Desde quando você percebe que isso vem acontecendo? (Investigar se houve momentos de melhora ou de agravamento e que fatores a participante associa a esses momentos)

\section{Informações relativas ao tratamento}

- Há quanto tempo você faz tratamento no GRATA?

- Como você ficou sabendo da existência do serviço? Como foi a sua admissão?

- Qual a sua percepção em relação ao tratamento? Há alguma parte do tratamento que você considera mais fácil? E difícil? Por quê?

- Você se sente acolhida pelos profissionais que the atendem?

- Conte-me um momento marcante que você viveu durante o atendimento.

- Você já fez seguimento em algum outro serviço ou com algum profissional fora do GRATA?

\section{Situação emocional da participante}

- Pensando nas suas emoções, depois que começou o transtorno alimentar, que sentimentos você passou a experimentar com mais frequência? Como está hoje? (Investigar a que comportamentos esses sentimentos estão associados)

- Qual é a principal dificuldade que você passou a enfrentar após a instalação do quadro? 
- O que faz para enfrentar suas dificuldades? O que ajuda a amenizar esses problemas? Em que situações essa ajuda traz bons resultados?

\section{A rede social e pessoal da participante (Mapa de Redes)}

- Você tem muitos amigos? Como você descreveria essas relações? Em que lugar do Mapa de Redes você colocaria essas pessoas?

- Você namora? Como é o relacionamento?

- Essas relações sempre foram dessa forma ou era diferente antes da ocorrência do transtorno alimentar?

- Você tem atividades de lazer? Quais? Com quem costuma realizá-las?

- Antes da instalação do quadro também era assim?

- Como são suas relações com as pessoas do seu trabalho (ou escola)? Sempre foi assim? Em que lugar do Mapa de Redes você colocaria essas pessoas?

- Você pratica outras atividades além do trabalho (ou escola)? Quais? Como é sua relação com as pessoas que freqüentam esse meio? Em que lugar do Mapa de Redes você colocaria essas pessoas?

- Houve alguma alteração na sua rotina de vida por causa do transtorno alimentar? Quais?

- Quem costuma te acompanhar nas consultas no ambulatório? Em que lugar do Mapa de Redes você colocaria essas pessoas?

\section{A rede familiar da participante (Genograma)}

- Quem mora com você na sua casa?

- Como você descreveria as relações que você mantém com essas pessoas? Em que lugar do Mapa de Redes você as colocaria?

- Você gostaria que fosse diferente?

- Como eram essas relações antes da ocorrência do transtorno alimentar?

- Hoje em dia é diferente? Em que sentido? Como foi mudando?

- Como seus familiares souberam da bulimia? Quem soube primeiro? Qual foi a reação deles?

- Quem é a pessoa que você sente que lhe dá mais apoio nesse momento? Em que parte do Mapa de Redes você colocaria essa pessoa?

- Você sente que realmente tem tido apoio da sua família para lidar com o transtorno alimentar? Como isso acontece?

- Por que você acha que eles reagem dessa forma perante o seu quadro?

- Você gostaria que eles lidassem com o seu problema de uma forma diferente?

- Alguém da sua família se afastou de você em função do que aconteceu? Como está essa relação atualmente? 
- Qual é a pessoa ou grupo de pessoas com quem você pode contar hoje para enfrentar a situação vivida?

- Como são suas relações os membros da sua família de origem (pais, irmãos, tios, avós, etc.)?

- Eles sabem da bulimia? O que eles falam para você sobre o seu problema, qual é a compreensão que eles têm? Você se sente entendida por eles? Como lidam com isso?

- Como é sua relação com seus filhos (se houver)?

- Como é sua relação com seu marido (se houver)?

- Você teve outras relações amorosas ou conjugais que você julgue importantes?

- Como foi para você ter participado desta entrevista?

- Você gostaria de receber de volta o Mapa de Redes e o Genograma?

\section{Desfecho da entrevista}

- Por que você concordou em participar dessa pesquisa?

- Você acha que as perguntas que eu fiz a você corresponderam ao que você achava que eu iria perguntado a seu respeito?

- Será que teria mais algum assunto que nós poderíamos conversar para compreender esse tema?

- Haveria outras questões que você julga importantes, que a sua opinião seria importante eu saber para compreender sua rede de relações familiares e sociais?

- Você acha que as perguntas que eu fiz a você são úteis para que o leitor possa compreender sua trajetória de vida? Por quê?

- Por favor, escolha um nome que eu possa utilizar para referir-me a você na pesquisa 


\section{Apêndice 2. Termo de Consentimento Livre e Esclarecido \\ Termo de Consentimento Livre e Esclarecido \\ (pacientes acima de 18 anos)}

Eu me chamo Carolina Leonidas, sou estudante do Programa de Pós-graduação em Psicologia da Universidade de São Paulo (USP) e estou realizando uma pesquisa com a finalidade de investigar as relações familiares de mulheres jovens e adultas com bulimia nervosa.

Essa pesquisa está sendo desenvolvida sob orientação do Prof. Dr. Manoel Antônio dos Santos, pesquisador vinculado ao NEPPS - Núcleo de Ensino e Pesquisa em Psicologia da Saúde da Faculdade de Filosofia, Ciências e Letras de Ribeirão Preto-USP.

Faz parte do estudo conhecer um pouco da história de cada participante por meio de uma conversa individual, que deve durar cerca de 60 minutos. Caso esteja de acordo, você participará de uma entrevista que abordará questões sobre o seu contexto de vida, o transtorno alimentar e a forma como você percebe as relações que você estabelece com seus familiares, amigos e outras pessoas do seu meio. Eu gravarei essa conversa, se for permitido por você. O motivo de estar gravando é para não se perder nada do que me for dito, evitando passar despercebido algum detalhe importante.

Tudo o que você me disser somente será utilizado para esse tipo de estudo e você não será identificada em momento algum, podendo até escolher um outro nome (fictício), caso desejar, com o qual você gostaria que eu a identificasse nesse estudo.

Mesmo depois de começarmos a pesquisa você poderá desistir a qualquer momento de participar do estudo, caso não concorde ou não se sinta mais à vontade para prosseguir, sem que isso traga prejuízo para a continuidade do seu atendimento junto ao serviço.

Ao aceitar participar desse estudo você estará contribuindo para que se saiba mais sobre a rede de apoio social, bem como os sentimentos e necessidades emocionais das pessoas que são atendidas neste serviço (Grupo de Assistência em Transtornos Alimentares do Ambulatório de Nutrologia do HC-FMRP-USP) e, com isso, os profissionais poderão ajudar melhor você e outras pessoas que estão sendo atendidas.

Você não corre nenhum risco significativo ao participar dessa pesquisa. Caso experimenta algum tipo de desconforto psicológico, poderá conversar com a equipe de Psicologia do serviço, composta por psicoterapeutas. 
Eventuais despesas que você tiver para participar desse estudo serão ressarcidas pelos pesquisadores. A entrevista será agendada em um dos dias de seu retorno ao serviço.

Diante do exposto, declaro que estou ciente das informações recebidas e que concordo voluntariamente em participar dessa pesquisa, recebendo uma cópia desse Termo, o que me permitirá entrar em contato com os pesquisadores em algum outro momento, caso eu deseje ou sinta necessidade de obter novos esclarecimentos a respeito desta pesquisa.

Ribeirão Preto de de 2010.

Nome da Participante:

RG:

Assinatura da participante:

Assinatura da pesquisadora-responsável:

Fone para contato: (16) 36023645 (Prof. Dr. Manoel Antônio dos Santos), de 2a a 6a feira, das 8 às 17 horas.

Endereço: NEPPS - FFCLRP-USP. Departamento de Psicologia e Educação. Centro de Psicologia e Pesquisa Aplicada. Bloco 5. Av. Bandeirantes, 3900, Monte Alegre, 14040-901 Ribeirão Preto-SP. 